July 1996

\title{
Volatilization and Redox Testing in a DC Arc Melter: FY-93 and FY-94
}

\author{
RECEIVED \\ OCT $0>9996$ \\ OSTI
}

J. D. Grandy

J. W. Sears

N. R. Soelberg

G. A. Reimann

M. E. Mollwain

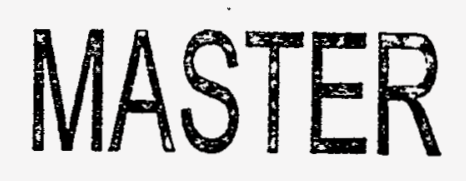

DISTRIBUTION OF THIS DCCUHENT IS URTIMTE

LOCKHEED MATTIN 


\title{
Volatilization and Redox Testing in a DC Arc Melter: FY-93 and FY-94
}

\author{
J. D. Grandy \\ J. W. Sears \\ N. R. Soelberg \\ G. A. Reimann \\ M. E. Mcllwain
}

Published July 1996

\section{Idaho National Engineering Laboratory} Lockheed Martin Idaho Technologies Company Idaho Falls, ID 83415

Prepared for the

U.S. Department of Energy

Assistant Secretary for Environmental Management

Under DOE Idaho Operations Office

Contract DE-AC07-94ID13223 


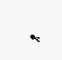




\section{DISCLAIMER}

Portions of this document may be illegible in electronic image products. Images are produced from the best available original document. 


\section{DISCLAIMER}

This report was prepared as an account of work sponsored by an agency of the United States Government. Neither the United States Government nor any agency thereof, nor any of their employees, makes any warranty, express or implied, or assumes any legal liability or responsibility for the accuracy, completeness, or usefulness of any information, apparatus, product, or process disclosed, or represents that its use would not infringe privately owned rights. Reference herein to any specific commercial product, process, or service by trade name, trademark, manufacturer, or otherwise does not necessarily constitute or imply its endorsement, recommendation, or favoring by the United States Government or any agency thereof. The views and opinions of authors expressed herein do not necessarily state or reflect those of the United States Government or any agency thereof. 


\section{ABSTRACT}

This work was a preliminary study of the effects of high-temperature arc melting on emissions of transuranic (TRU) surrogates, cesium, and high vapor pressure metals (HVPMs), both with and without a cold cap of feed materials in an iron-enriched basalt waste form with $\mathrm{TiO}_{2}$ and $\mathrm{ZrO}_{2}$ (IEB4). The effect of the reducing/oxidizing (redox) conditions on the retention of HVPMs and surrogate elements was also studied. Volatilization experiments were conducted in FY-93 and again in FY-94. Redox testing took place in FY-93.

Exhaust gas samples were obtained for melts ranging in temperature from 1200 to $2300^{\circ} \mathrm{C}$ during FY-93. The off gas samples were collected by a "Modified Method 5" system and analyzed to determine the volatilization rates of the HVPMs and surrogates. The comparison of volatilization rates between open melt vs. cold cap conditions did not reveal a definite correlation for reduced volatilization in the cold cap melts. Slag samples were also analyzed. By comparing the concentrations of HVPMs in the slags, a slight improvement in HVPM retention was seen for the cold cap melts. Except for chromium, most of the HVPMs volatilized from the melt. The surrogate elements tended to remain in the slag, but there was no definite correlation for improvement in surrogate retention in the cold cap experiments.

During the FY-93 campaign, the redox state was adjusted by adding carbon powder to produce a reducing state and by introducing air through a lance to produce an oxidizing state. Iron oxide ratios were analyzed for these samples to determine their final redox state. With the exception of chromium, the HVPMs evaporated from the melt regardless of the redox conditions. Of the surrogates, only cerium remained in the slag in significant amounts. The slags produced under oxidizing conditions formed many more crystalline phases than the glassy slags produced under reducing conditions.

Additional volatilization tests conducted in FY-94 under open melt and cold cap conditions were also used to collect mass balance data. Like the previous experiments, zinc and particularly cadmium and lead, evaporated from the melt while chromium remained. Cesium partitioned half into the slag and half into exhaust gas particulates. On average, the detailed mass balance closures for the HVPMs and surrogates were low. Mass balance closure for the HVPMs was approximately $60-70 \%$, except for chromium which was $35 \%$. Surrogate mass balance closures ranged from only $20-30 \%$. This result may be the result of the surrogates partitioning to the high alumina refractory that lines the inside of the arc melter crucible. 


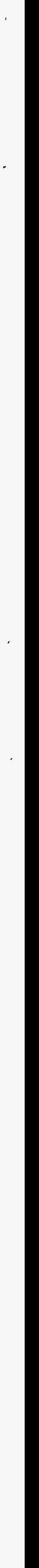




\section{EXECUTIVE SUMMARY ,}

The Idaho National Engineering Laboratory (INEL) small DC arc melter was designed and constructed in FY-92. The primary purpose of this melter system was to investigate the synthesis and properties of waste forms expected to result after thermal processing of INEL radioactive mixed wastes. After an initial series of tests in FY-92, the arc melter system was greatly modified in FY-93 so that experiments using toxic heavy metals could be conducted. Several programs, including Buried Waste Integration Demonstration (BWD), Private Sector Participation Initiative (PSPI), and Integrated Waste Processing Facility (IWPF) took advantage of the capabilities of the INEL small arc melter to investigate the effects of various processing conditions on the properties of thermally treated final waste forms. The arc melter was slightly modified again in FY-94 to accommodate collection of complete mass balance data. The arc melter generally operates between 10 and $40 \mathrm{~kW}$ with typical operating current and voltages at $110 \mathrm{~A}$ and $180 \mathrm{~V}$, respectively. The system operates with two side-by-side carbon electrodes in a melt chamber dimensioned 14 inches high and 9 inches in diameter when lined with a cast ceramic crucible one-half inch thick. It operates in batch mode, but an auger feeder can be used to add more material once the initial batch has been melted. The water cooled crucible jacket prevents slag/metal tapping.

Experimental work to evaluate the extent of vaporization in the small arc melter was conducted over a 2-year period with simulated mixed radioactive waste and soil over a temperature range of 1300 to $1900^{\circ} \mathrm{C}$. Organics and halogens were not used as part of the simulated waste streams since they were assumed to have burned off or volatilized in an incinerator prior to entering the melter. The radionuclide surrogates used in the program that were expected to mimic the chemical characteristics of transuranics (TRUs) and U compounds were $\mathrm{Ce}, \mathrm{Sm}, \mathrm{Nd}$, Eu and Gd for the early FY-93 tests. Later in FY-93 and all of FY-94, only cerium and samarium were used as TRU surrogates. Cesium is highly volatile metal and acts as a study for the radioactive isotope $\mathrm{Cs}^{137}$. The HVPMs used in the testing programs were $\mathrm{Cd}, \mathrm{Cr}, \mathrm{Cs}, \mathrm{Pb}$, and $\mathrm{Zn}$. These elements cover the range of boiling points of interest and are the major toxic contaminants in the wastes that may remain in the solids after incineration. Hg is present in INEL radioactive wastes but was not used in the experiments since it was assumed that it will completely volatilize during processing and end up in the air pollution control system where it must be treated as a secondary waste stream. 


\section{FY-93 Volatilization Tests}

There were three experimental campaigns conducted during FY-93 and FY-94. The first of these was the volatilization testing in FY-93 consisting of experiments that employed open melt and cold cap processing conditions. In these tests, the exhaust gases were collected while feed material containing the HVPMs and surrogates was introduced into the melt with the auger feeder. The exhaust gas particulates were collected using an "EPA modified Method 5" exhaust gas analyzer commonly used to monitor industrial stack emissions. Samples were sent to an independent laboratory for analysis. Data from the analysis were used to calculate volatilization rates in units of milligrams per hour for the elements of interest, specifically the HVPMs and radionuclide surrogates.

Examination of the data did not reveal an overwhelming correlation for reduction in volatilization in the cold cap melts vs. the open melts. This conclusion, however, may only point to the need for a thicker cold cap layer. Only in the case of chromium was there a clear indication of reduced volatilization in the cold cap experiments. Results for the other HVPMs show only a slight reduction in volatilization in most cases during cold cap conditions. The surrogates tended to remain in the slag under open melt or cold cap conditions.

Measured volatilization rates can be expected to be system dependent since the geometry, temperature profiles, exhaust gas flow rates, etc. that will affect volatilization will be unique for each melter system. Primary factors affecting volatilization are the amount and surface area of the slag, concentration of the volatile material in the slag, and slag temperature. The measured rates for the INEL small arc melter show in general the expected correlation between temperature and volatilization, i.e. higher rates for higher slag temperatures, although there are some exceptions. Lack of a strict correlation can likely be attributed to uncertainties in slag temperature and unknown HVPM and surrogate concentrations during exhaust gas sampling. In order to obtain reliable volatilization rate data for any processing system, detailed slag temperature must be taken along with slag samples to determine volatile element concentrations. 


\section{Redox Tests}

A second set of tests conducted in FY-94 tested the extremes in reducing or oxidizing conditions and their effect on melt chemistry and crystallization. Reducing conditions for two melts were achieved by using different levels of carbon blended into the melt mix. In the case of these two melts, one-half the stoichiometric amount of carbon needed to reduce iron oxides to metals was added and the second melt used twice the stoichiometric amount. Two levels of oxidation were maintained by introducing air under the surface of the melt with a water cooled air lance.

The redox state of the molten slag affects the types of minerals produced upon cooling in the glass-ceramic waste forms. The type of minerals produced determine the waste form chemical and physical durability. Since minerals have different affinity for toxic metals, cesium, and TRUs, the redox state may also affect their retention in the final waste form.

An overall generalization of the difference between slag material processed under reducing and oxidizing conditions is that the reduced melts produced mostly glassy slag while the oxidized melts developed substantially more crystalline structure even though the cooling rates were very similar. Redox conditions had little influence on the disposition of the HVPMs. With the exception of chromium, the HVPMs evaporated from the melt in both reducing and oxidizing environments. Chromium showed a strong tendency to form crystals in conjunction with iron, although the crystalline structures formed in reducing conditions tended to be much smaller and finer. Surrogates did not tend to collect preferentially in the crystalline phases as was hoped. This may be due primarily to relatively fast slag cooling rates once the melter is turned off. Of the surrogates, only cerium demonstrated an ability to remain in the slag in significant amounts retaining about half of the original amount in the simulated waste mix. The cerium was found in the glassy phases of the slag. In general, the rest of the surrogates were not found in the slag although there were exceptions. For instance, cesium showed modest retention under oxidizing conditions but was completely volatilized in the reducing environment.

\section{FY-94 Volatilization Tests}

Volatilization testing was continued in FY-94, again under open melt and cold cap. conditions. In these experiments the arc melter exhaust system was modified to streamline the 
task of obtaining a global mass balance. Masses of the slag (including metal, if any), particulates in the melter chamber, and particulate in the exhaust system were collected and measured. In order to do elemental masses balances, the slag and particulates were analyzed using energy dispersive $x$-ray spectroscopy and $x$-ray fluorescence spectroscopy. Additionally, they were also analyzed using inductively coupled plasma-atomic emission absorption spectroscopy. All of these analytical methods produced similar results.

A general mass balance comparing the amount of starting material with the amount of material after processing revealed an average mass loss of $10.7 \mathrm{wt} \%$. This is a typical amount expected to be lost from carbonated and hydrated compounds in the starting material, which will be released as carbon dioxide and water vapor during processing. A more complete mass balance would include measurement of the exhaust gas flow rate and input air flow rate rather than assuming the deficit mass was part of the off-gas. While measurement and analysis of exhaust gas flows are necessary to obtain a complete mass balance, in practical terms, it is . somewhat complex and expensive. Also, since conservation of total mass must hold, measurements of only solid masses may be considered adequate for the scope and requirements of this project.

The elemental mass balance for the HVPMs revealed that the majority zinc, cadmium and lead ended up in particulates in the melt chamber and exhaust system while chromium tended to remain in the slag. The elemental mass balances in general did not account for the metal amounts originally introduced, particularly for chromium having a mass balance closure of just $35 \%$. Mass balances for the other toxic metals on average were $80 \%$ for lead, $73 \%$ for zinc and $67 \%$ for cadmium. Cesium tended to partition half into the slag and half into the off-gas particulates. The mass balance closure for cesium was just $60 \%$. The partitioning behavior of the surrogate elements, cerium and samarium, is uncertain due to the very poor mass balance results which range from $20-30 \%$. These elements are expected to remain in the slag and indeed while the relative mass amounts found in the slag are much higher (about 10 times) than for the off-gas particulates, the poor mass balance closure leaves open the question about the ultimate fate of the surrogate elements.

A reason for the poor mass balances may be the result of two factors. First, the mass of the slag is substantially larger than that of the particulates. Therefore, a small discrepancy in the measured concentrations of HVPMs and surrogates could cause large discrepancies in the overall mass balance for an element. Second, the widely varying mass closure results suggest the possibility of elemental partitioning to different parts of the slag. Although this 
possibility was taken into account by taking samples from the top and bottom parts of the melt, elements may have been concentrated in regions of the slag that were not sampled. Based on these possibilities, more samples should be analyzed to determine average concentrations of an element in the slag. Another possiblility is that the surrogates, in particular, may have partitioned into the high alumina refractory liner that contains the slag inside the water cooled crucible of the arc melter.

\section{Conclusions and Recommendations}

The volatilization experiments conducted in FY-93 and FY-94 provided valuable information on partitioning of toxic heavy metals and radionuclides via surrogate elements in a high-temperature arc melter processing system. During the course of the experiments many improvements to the data gathering and analysis procedures were made, and areas where further improvements could be made were identified. As a minimum, data collection must include measurement of solid mass amounts distributed during processing and elemental analysis of specific areas where solids have accumulated within the processing system. Exhaust gas mass amounts and elemental analysis can be done if budget constraints allow and if the scope of a project requires it. This may be dictated for preproduction systems where EPA and other environmental regulations will necessitate exhaust gas measurements to ensure compliance of that system and future production systems. Off-gas mass measurements will allow total mass balance measurements to be made but are not necessary to determine solid mass partitioning within the melter and air pollution control systems.

Measurement of volatilization rates for any specific processing system requires good temperature and volatile element concentration measurements of the slag. Although individual processing systems will affect volatilization due to geometry, surface area of the melt, energy input mechanism, etc., slag temperature and volatile element concentration are the primary factors affecting volatilization. Future testing must include radioactive bench-scale testing where these considerations are taken into account. Also, modeling of the partitioning mechanisms within specific processing systems may prove to be an important aspect in gaining knowledge for control of volatilization during radioactive waste processing. 
Overall results of these experiments show that provisions must be made for the air pollution control system of any high-temperature radioactive processing system containing toxic metals to deal with them since the majority of these metals volatilized. Approximately half or more of any cadmium, zinc, lead, and cesium will be volatilized or entrained and end up in the exhaust treatment system. In addition, some of the radionuclide elements (based on results from the surrogate elements) will also end up in the off-gas system. Particulates containing these elements must either be rerouted back to the melter or treated as a separate secondary waste stream. 


\section{ACKNOWLEDGMENTS}

This work was supported through several related projects within the Environmental Management Branch at the INEL and the Office of Waste Technology Development, Environmental Management Technology Evaluation Project (EMTEP). The assistance of O. Wiersholm (IWTP), A. L. Ayers, Jr., and L. G. Gale (IWPF) in monitoring and assisting in the implementation of the project is appreciated. The guidance of G. L. Anderson, Advanced Mixed Waste Treatment Project (AMWTP), Private Sector Participation Initiative (PSPI), in coordinating this activity with other concurrent projects is also appreciated. Technical consultation, construction, and operational support by B. C. Benefield, R. J. Bitsoi, A. D. Donaldson, J. M. Hillary, D. Duford, A. L. Jones, J. E. Lee, B. K. Marshall, J. G. Rodriguez, J. Devoran, R. Thompson, A. D. Watkins, J. D. Choules, and G. C. Wilson is greatly appreciated. Assistance in the preparation of the manuscript by T. K. Pettingill, T. A. Ward and M. M. Siefken is also appreciated. 



\section{CONTENTS}

ABSTRACT $\ldots \ldots \ldots \ldots \ldots \ldots \ldots \ldots \ldots \ldots \ldots \ldots \ldots \ldots \ldots \ldots \ldots$

EXECUTIVE SUMMARY $\ldots \ldots \ldots \ldots \ldots \ldots \ldots \ldots \ldots \ldots \ldots \ldots \ldots$

ACKNOWLEDGMENTS $\ldots \ldots \ldots \ldots \ldots \ldots \ldots \ldots \ldots \ldots \ldots \ldots \ldots \ldots$

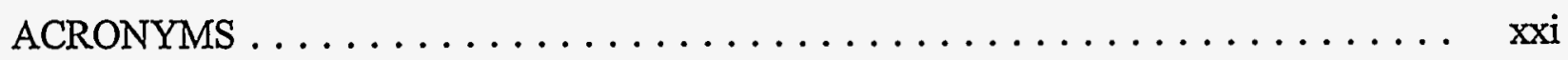

1. INTRODUCTION ........................

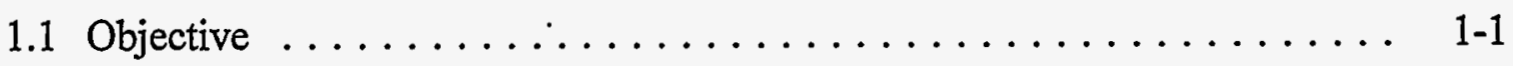

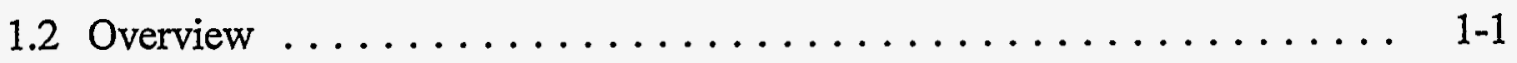

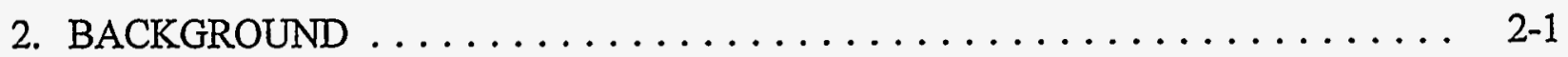

3. ARC MELTER DESCRIPTION AND HISTORY $\ldots \ldots \ldots \ldots \ldots \ldots \ldots$. . . . . . . .

3.1 Original Arc Melter . . . . . . . . . . . . . . . . 3-1

3.2 FY-93 Arc Melter Modifications $\ldots \ldots \ldots \ldots \ldots \ldots \ldots \ldots \ldots$. . . . . . . . . .

3.3 FY-94 Arc Melter Modifications ................... 3-5

4. ARC MELTER OPERATIONS $\ldots \ldots \ldots \ldots \ldots \ldots \ldots \ldots \ldots \ldots \ldots$ 4-1

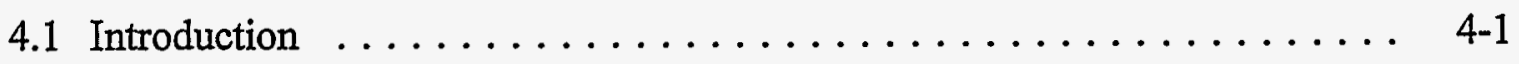

4.2 Operating the Arc Melter $\ldots \ldots \ldots \ldots \ldots \ldots \ldots \ldots \ldots \ldots$ 4-1

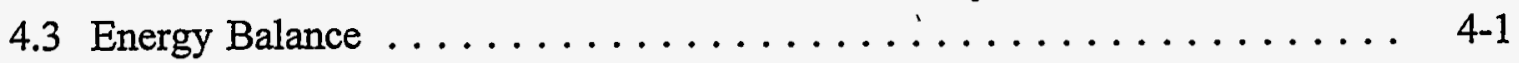

4.4 Electrode Erosion $\ldots \ldots \ldots \ldots \ldots \ldots \ldots \ldots \ldots \ldots \ldots \ldots$

4.5 Temperature Monitoring $\ldots \ldots \ldots \ldots \ldots \ldots \ldots \ldots \ldots \ldots$. . . . . . . . . .

5. VOLATILIZATION AND REDOX TESTING OVERVIEW $\ldots \ldots \ldots \ldots \ldots$ 5-1

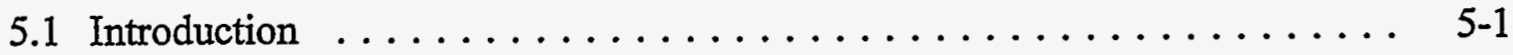

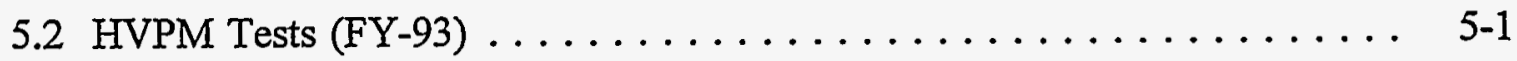

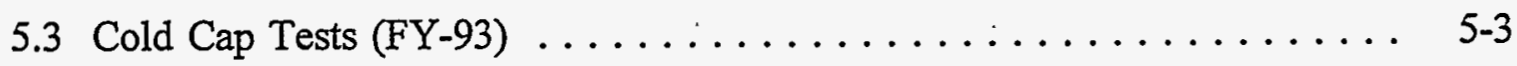

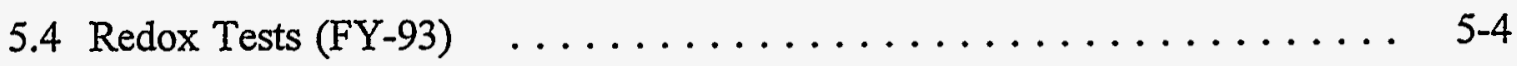

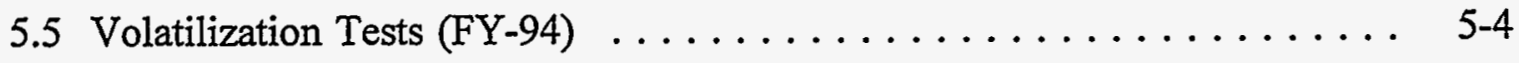


6. HVPM RETENTION AND EXHAUST GAS ANALYSIS (FY-93) $\ldots \ldots \ldots$. . . 6-1

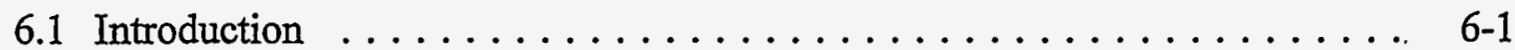

6.2 Data Collection ........................ $6-1$

6.2 .1 Slag Sampling ..................... 6-1

6.2 .2 Exhaust Gas Sampling . . . . . . . . . . . . . . 6-4

6.3 XRD Analysis of Exhaust Particulate . . . . . . . . . . . . . . 6-9

6.4 HVPM Tests: Analysis and Results . . . . . . . . . . . . . . . . . 6. 6-9

6.4.1 Slag Composition Evaluation . . . . . . . . . . . . . . . 6-9

6.4 .2 Slag Characterization . . . . . . . . . . . . . 6 6-12

6.5 Cold Cap Tests: Analysis and Results . . . . . . . . . . . . . . . 6-19

6.5.1 Slag Characterization .................. 6-19

6.6 Exhaust Particulate Composition $\ldots \ldots \ldots \ldots \ldots \ldots \ldots \ldots$. . . . . . . . . . .

6.7 Volatilization Rates . . . . . . . . . . . . . . . . . 6-26

7. REDOX MEASUREMENTS $($ FY-93) $\ldots \ldots \ldots \ldots \ldots \ldots \ldots \ldots \ldots \ldots$. . . . . . . .

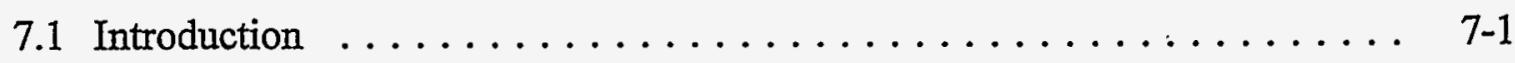

7.2 Experimental Conditions . . . . . . . . . . . . . . . 7-2

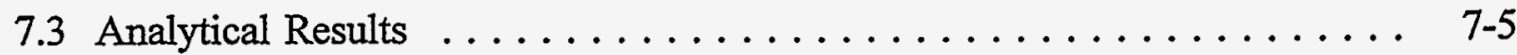

$7.3 .1 \mathrm{Fe}^{+2} / \mathrm{Fe}^{+3}$ Ratios . . . . . . . . . . . . . 7-5

7.3.2 SEM/EDXS Analysis of Slag $\ldots \ldots \ldots \ldots \ldots \ldots$ 7-7

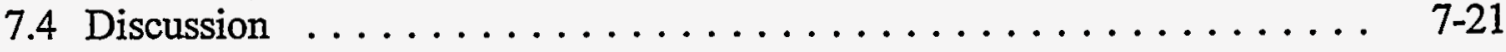

8. VOLATILIZATION TESTS $($ FY-94) . . . . . . . . . . . . . . . . 8-1

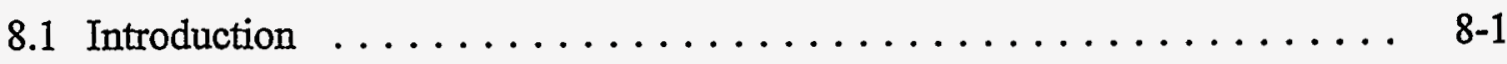

8.2 Experimental Conditions $\ldots \ldots \ldots \ldots \ldots \ldots \ldots \ldots \ldots \ldots \ldots \ldots \ldots$

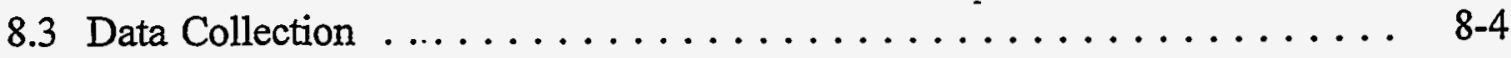

8.4 General Mass Balance . . . . . . . . . . . . . . . . . . . . 8 8

8.5 Off-Gas Particulate Analysis . . . . . . . . . . . . . . . . 8 8

8.5.1 EDXS and XRF Analysis of Exhaust Filter Particulate . . . . . . 8-8

8.5.2 ICP Analysis of Exhaust Filter Particulate . . . . . . . . . . . 8 8 8

8.5.3 EDX and XRF Analysis of Melter Chamber Particulate . . . . 8. 8-10

8.5.4 ICP Analysis of Melter Chamber Particulate. . . . . . . . . . 8 8-12

8.6 Slag Composition Analysis . . . . . . . . . . . . . . . 8-12

8.6.1 EDXS and XRF Slag Analysis $\ldots \ldots \ldots \ldots . \ldots \ldots$ 8-13

8.6 .2 ICP and FLAA Slag Analysis . . . . . . . . . . 8-26

8.7 Detailed Mass Balance for HVPMs and Surrogates . . . . . . . . . . . 8-27 
8.7.1 Detailed Mass Balances for HVPMs . . . . . . . . . . 8-27

8.7.2 Detailed Mass Balances for Radionuclide Surrogates. . . . . . 8 8-30

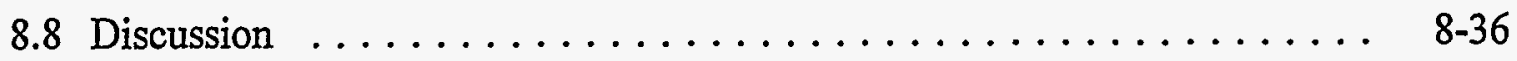

9. CONCLUSIONS AND RECOMMENDATIONS $\ldots \ldots \ldots \ldots \ldots \ldots \ldots$ 9.

9.1 Arc Melter System and Operations . . . . . . . . . . . . . . 9-1

9.2 Effects of Redox Conditions .................... 9-3

9.3 Volatilization in a DC Arc Melter $\ldots \ldots \ldots \ldots \ldots \ldots \ldots . \ldots . . \ldots .4$

9.4 Conclusions . . . . . . . . . .

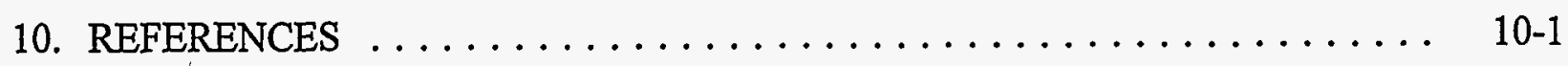

APPENDIX A - LDRD FY-94 Annual Report $\ldots \ldots \ldots \ldots \ldots \ldots \ldots \ldots \ldots$ A-1

APPENDIX B - Melter Off-Gas Sampling Proceedures $\ldots \ldots \ldots \ldots \ldots \ldots$ B-1

APPENDIX C - Composition and Normalization Calculation Worksheets $\ldots \ldots \ldots$ C-1

APPENDIX D - Volatilization Rate Calculations . . . . . . . . . . D 1

APPENDIX E - EDXS and XRF Data $\ldots \ldots \ldots \ldots \ldots \ldots \ldots \ldots \ldots \ldots \ldots \ldots \ldots \ldots$

APPENDIX F - ICP and FLAA Data $\ldots \ldots \ldots \ldots \ldots \ldots \ldots \ldots \ldots \ldots \ldots \ldots \ldots \ldots$ 


\section{FIGURES}

3.1 Photograph of the modified bench-scale arc melter in FY-93 . . . . . . . . . . 3-3

3.2 Schematic of the modified bench-scale arc melter . . . . . . . . . . . . . 3-4

3.3 Photograph of the arc melter system as configured for FY-94 tests . . . . . . 3-6

3.4 Photograph of the off-gas system used during the FY-94 tests . . . . . . . . . 3-7

3.5 Schematic of the off-gas system utilized during the FY-94 tests . . . . . . . . 3-8

3.6 Micarta seal and rod-wiper assembly for the electrodes used during FY-94 . . . . 3-10

3.7 Schematic of the modified electrode drive mechanism . . . . . . . . . . . 3-11

3.8 Schematic of the arc melter crucible assembly $\ldots \ldots \ldots \ldots$. . . . . . . . . 3-12

3.9 Schematic of the pin-hole camera assembly . . . . . . . . . . . . . 3-13

4.1 Energy input data for the HVPM run ARM090894 with a cold cap. . . . . . . . . 4-3

4.2 Energy balance data for the HVPM run ARM090894 with a cold cap . . . . . . . 4-3

4.3 Energy input data for the HVPM run ARM092094 without a cold cap . . . . . . . 4-4

4.4 Energy balance data for the HVPM run ARM020894 without a cold cap . . . . . 4 4-4

4.5 Anode and cathode carbon loss rates in grams per amp-hour . . . . . . . . . 4-8

4.6 . Used carbon electrodes coated with ZYP silicon carbide . . . . . . . . . . . 4-10

$4.6 \mathrm{~b}$ Used carbon electrodes coated with plasma-sprayed silicon . . . . . . . . . . 4-10

4.7 a Carbon feed tube extender with $\mathrm{SiC}$ coating $\ldots \ldots \ldots \ldots \ldots \ldots$. . . . . . . . . . . . . .

$4.7 \mathrm{~b}$ Carbon feed tube extender with no coating . . . . . . . . . . . . . 4-11

4.8 Schematic of a water cooled $\mathrm{TC}$ probe . . . . . . . . . . . . . . . 4-12

4.9 Temperature response of the slag and power input vs. time $\ldots \ldots \ldots$. . . . . . 4-14

6.1 Sketch of the slag sampling system used during the FY-93 HVPM studies . . . . 6-3

6.2 Schematic of exhaust gas sampling train $\ldots \ldots \ldots \ldots \ldots \ldots \ldots$

6.3 Open melt vs. cold cap cesium volatilization rates $\ldots \ldots \ldots \ldots \ldots$. . . . . 6-30

6.4 Open melt vs. cold cap cadmium volatilization rates . . . . . . . . . . 6-30

6.5 Open melt vs. cold cap cerium volatilization rates . . . . . . . . . . . . 6-31

6.6 Open melt vs. cold cap samarium volatilization rates . . . . . . . . . . . 6-31

7.1 Schematic of the airloxygen lance $\ldots \ldots \ldots \ldots \ldots \ldots \ldots \ldots$

7.2 SEM micrographs for the slightly reduced $\operatorname{slag} \ldots \ldots \ldots \ldots \ldots \ldots \ldots$

7.3 SEM micrographs for the highly reduced slags . . . . . . . . . . . . . . . 7-10

7.4 SEM micrographs for the slightly oxidized slags . . . . . . . . . . . . . . . 7-14

7.5 SEM micrographs for the highly oxidized slags $\ldots \ldots \ldots \ldots \ldots \ldots \ldots$. . . . . . . 
8.1 XRF and EDXS chemistry results from slag material - ARM082394 . . . . 8 8-15

8.2 XRF and EDXS chemistry results from slag material - ARM082694 . . . . . 8 8-17

8.3 XRF and EDXS chemistry results from slag material - ARM090694 . . . . . . 8-19

8.4 XRF and EDX chemistry results from slag material - ARM090894 . . . . . . 8-21

8.5 EDXS chemistry results from slag material - ARM092094 . . . . . . . . 8-23

8.6 EDXS chemistry results from slag material - ARM092294 . . . . . . . . . 8-25

8.7 Calculated composition of the starting IEB4/A-40 waste-soil mixture $\ldots \ldots \ldots .88-29$ 


\section{TABLES}

2.1 Weight percent compositions of the IEB series waste forms $\ldots \ldots \ldots \ldots \ldots .2-2$

4.1 Operating conditions and electrode erosion data for the FY-93 experiments . . . . 4-6

4.2 Operating conditions and electrode erosion data for the FY-94 experiments . . . . 4-7

5.1 Melting and boiling points of HVPMs and surrogates plus oxides $\ldots \ldots \ldots \ldots$ 5-2

5.2 HVPM analyses for FY-93 HVPM and cold cap experiments . . . . . . . 5-3

6.1 FY-93 HVPM and cold cap test series . . . . . . . . . . . . . . 6-2

6.2 Metals sample information for the FY-93 HVPM and cold cap test series . . . . . . 6-7

6.3 Metals sample conditions for FY-93 HVPM and cold cap test series . . . . . . 6 6-8

6.4 Chemical compositions for 1 kilogram of IEB4 mixes $\ldots \ldots \ldots \ldots \ldots \ldots$. $6-10$

6.5 Chemical composition of the FY-93 HVPM experiments . . . . . . . . 6-11

6.6 HVPM02 slag materials characterization $\ldots \ldots \ldots \ldots \ldots \ldots \ldots \ldots \ldots .6 \ldots \ldots .14$

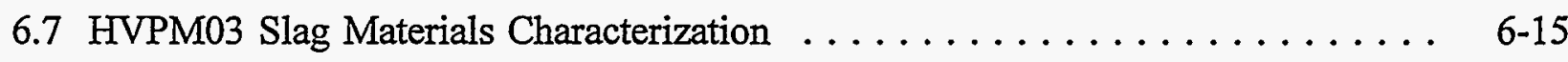

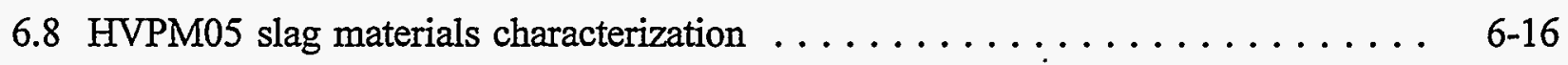

6.9 HVPM06-01 Slag Materials Characterization $\ldots \ldots \ldots \ldots \ldots \ldots \ldots \ldots .6 \ldots . \ldots \ldots$

6.10 HVPM06-02 Slag Materials Characterization $\ldots \ldots \ldots \ldots \ldots \ldots \ldots .6 .6 \ldots$

6.11 Cold-cap CC01 slag materials characterization $\ldots \ldots \ldots \ldots \ldots \ldots \ldots .6 .20$

6.12 Cold-cap CC02 slag materials characterization $\ldots \ldots \ldots \ldots \ldots \ldots \ldots .6-21$

6.13 Cold-cap $\mathrm{CC} 03$ slag materials characterization $\ldots \ldots \ldots \ldots \ldots \ldots \ldots .6 .22$

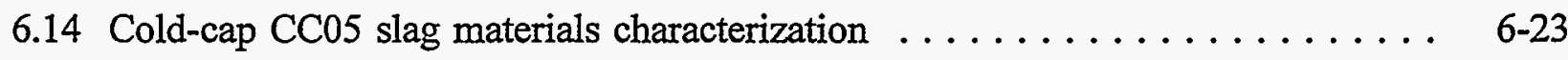

6.15 FY-93 HVPM experiments - particulate elemental analysis. . . . . . . . . 6-25

6.16 FY-93 cold cap experiments - particulate elemental analysis . . . . . . . . 6-25

6.17 Volatilization rates for the HVPMs in open melt conditions . . . . . . . . 6-28

6.18 Volatilization rates for the surrogates in open melt conditions . . . . . . . . $6-28$

6.19 Volatilization rates for the HVPM's under cold cap conditions . . . . . . . . . 6 6-29

6.20 Volatilization rates for the surrogates under cold cap conditions . . . . . . . . 6-29

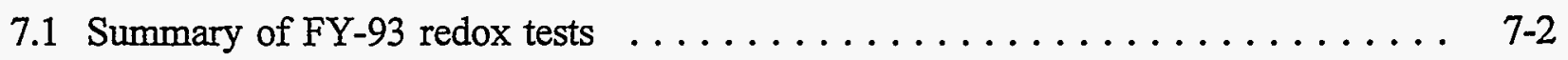

7.2 Redox results over a range of reducing and oxidizing conditions . . . . . . 7-7

7.3 EDXS analysis of designated spots in the slightly reduced slag (RED01) . . . . 7-10

7.4 EDXS analysis of designated spots in the highly reduced slag (RED02) . . . . 7-13

7.5 EDXS analysis of designated spots for the slightly oxidized slag (OX02) . . . . 7-18

7.6 EDXS analysis of designated spots in the highly oxidized slag (OX03) $\ldots \ldots$ 7-21

7.7 EDX general area scan analysis for the redox tests $\ldots \ldots \ldots \ldots \ldots \ldots \ldots .7-23$

8.1 General parameters and feeding information for the FY-94 HVPM runs . . . . . 8 8-2 
8.2 Data and operating conditions for the FY-94 experiments $\ldots \ldots \ldots \ldots \ldots$ 8-3

8.3a Mass balance information for the FY-94 HVPM experiments $\ldots \ldots \ldots \ldots . .8$. 6

8.3b Mass balance information for the FY-94 HVPM experiments. . . . . . . 8-7

8.4 EDXS and XRF analysis - Average concentrations for HVPMs and surrogates in exhaust filter particulate $\ldots \ldots \ldots \ldots \ldots \ldots \ldots \ldots \ldots$ 8-9

8.5 ICP analysis - Average concentrations for HVPMs and surrogates in exhaust

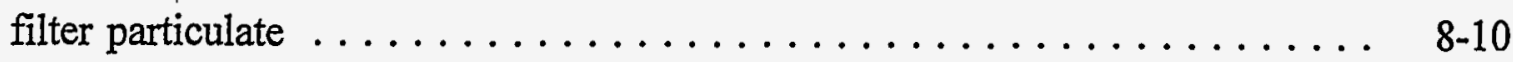

8.6 EDX and XRF melter chamber condensate/particulate analysis $\ldots \ldots \ldots \ldots 8$ 8-11

8.7 ICP analysis - Average concentrations for HVPMs and surrogates for particulate collected from the melter chamber $\ldots \ldots \ldots \ldots \ldots \ldots \ldots \ldots \ldots$. . . . . . . .

8.8 EDX and XRF analysis of ARM082394 slag $\ldots \ldots \ldots \ldots \ldots \ldots \ldots \ldots . \ldots \ldots$ 8-14

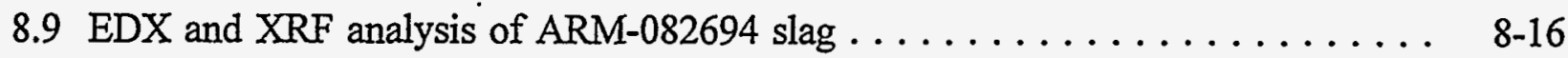

$8.10 \mathrm{EDX}$ and XRF analysis of ARM-090694 slag $\ldots \ldots \ldots \ldots \ldots \ldots \ldots$ 8-18

8.11 EDX and XRF analysis of ARM-090894 slag . . . . . . . . . . . . 8-20

8.12 EDX analysis of ARM-092094 slag $\ldots \ldots \ldots \ldots \ldots \ldots \ldots \ldots \ldots . \ldots \ldots$ 8-22

8.13 EDX Analysis of ARM-092294 Slag . . . . . . . . . . . . . . .

8.14 ICP analysis - Average concentrations for HVPMs and surrogates in the slag . . 8-26

8.15 IEB4/A-40, HVPMs, and surrogates composition for the FY-94 tests . . . . . 8 8-28

8.16 Mass balance information for solid materials in the arc melter system . . . . . 8-30

8.17a HVPM mass balance using EDXS and XRF spectroscopic analysis $\ldots \ldots \ldots$ 8-31

8.17b HVPM mass balance using EDXS and XRF spectroscopic analysis $\ldots \ldots \ldots 8-32$

8.18a HVPM mass balance using ICP spectroscopic analysis. . . . . . . . . . 8-33

8.18b HVPM mass balance using ICP spectroscopic analysis. $\ldots \ldots \ldots \ldots \ldots$ 8-34

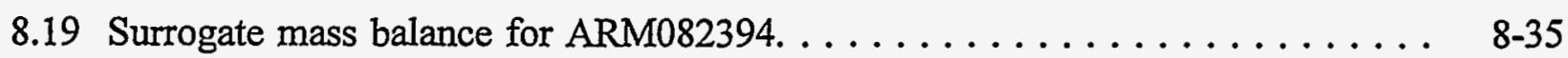





\begin{tabular}{ll} 
AES & atomic emission spectroscopy \\
ASG & aluminosilicate glass \\
BN & boron nitride \\
BWID & Buried Waste Integration Demonstration \\
DC & direct current \\
DOE & Department of Energy \\
EDXS & energy dispersive X-ray spectroscopy \\
EPA & Environmental Protection Agency \\
FLAA & flame atomic absorbtion (spectroscopy) \\
FWF & final waste form \\
HEPA & high efficiency particulate air (filter) \\
HVPM & high vapor pressure metal \\
ICP & inductively coupled plasma \\
IEB & iron-enriched basalt \\
IEB4 & iron-enriched basalt with ZrO $_{2}$ and TiO ${ }_{2}$ additions \\
INEL & Idaho National Engineering Laboratory \\
IRC & INEL Research Center \\
MFP & mixed fission product \\
PSPI & Private Sector Participation Initiative \\
RFP & Rocky Flats Plant \\
RTD & resistance temperature device \\
RWMC & Radioactive Waste Management Complex \\
SDA & Subsurface Disposal Area \\
SEM & scanning electron microscopy \\
slpm & standard liters per minute \\
TC & thermocouple \\
TCLP & toxicity characteristic leach procedure \\
TRU & transuranic \\
TSA & Transuranic Storage Area \\
WSL & Waste Stream Limits \\
XRD & X-ray diffraction \\
XRF & X-ray fluoresence \\
& \\
\hline
\end{tabular}




\section{INTRODUCTION}

The purpose of these experiments was to study the dissolution, retention, volatilization, and trapping of transuranic radionuclide elements (TRUs), mixed fission and activation products, and high vapor pressure metals (HVPMs) during processing in a high temperature arc furnace. In all cases, surrogate elements (lanthanides) were used in place of radioactive ones. The experiments were conducted utilizing a small DC arc melter developed at the Idaho National Engineering Laboratory (INEL) Research Center (IRC). The small arc melter was originally developed in 1992 and has been used previously for waste form studies of iron enriched basalt (IEB) and IEB with zirconium and titanium additions (IEB4). Section 3 contains a description of the small arc melter and its operational capabilities are discussed in Chapter 4. The remainder of the document describes each testing program and then discusses results and findings.

In any high temperature melter system, the exhaust gases will contain particulate that must be processed by the air pollution control system (APCS) or rerouted back to the melter. In general, this material or "carryover" can arise from two sources, either from small particles of the waste material that become entrained in the flow or from material that is vaporized from the melt and that subsequently condenses into particulates which are carried away in the off-gas stream. Once carryover has been collected, it is intimately mixed, and it is difficult to differentiate which part was entrained and which part was volatilized from the melt. Elements or compounds with very low boiling points, can be expected to contribute heavily to carryover in the exhaust gas stream. This behavior can be verified if high concentrations of these materials end up in the carryover mass. This turns out to be true, particularly in the case of the HVPM's. Therefore, while most of the data and discussions in this report refer to volatilized material, it is recognized that some portion of the material collected for analysis was due to entrainment.

\subsection{Objective}

The overall objective of the testing efforts described in this report is to discover the conditions under which HVPMs will volatilize from the melt and to determine methods to trap and dispose of these elements. These tests indicated the extent of dissolution and maximum retention of these elements in the slag. Along with the major objective, valuable experience in operating an arc melter was gained. Improvements to the arc melter system were made regarding electrode erosion, refractory performance, slag temperature monitoring, and process control. Vaporization of some of the HVPMs is unavoidable but it may be minimized through the use of proper engineering and operational controls. Vaporization of TRUs and mixed fission products (MFPs), on the other hand, could cause excessive 
contamination in the off-gas components and possibly lead to criticality or unacceptable exposure limits. It is preferred that TRUs and MFPs remain in the melt and go into the primary final waste form.

\subsection{Overview}

The experiments consisted of melting simulated waste materials mixed with typical INEL soil obtained from the Radioactive Waste Management Complex (RWMC). Both solid and gaseous products were collected and analyzed to determine the partitioning behavior of each of the elements of interest. Test variables were molten slag temperature, open melt vs. cold cap, the method for feeding material into the melter, and oxidizing vs. reducing conditions in the melter. Melter operations that control these variables were material feed rate, material composition, power input, arc length, refractory insulation, and insertion of air into the melt. Results identify the extent of volatilization of HVPM under these controlled conditions. Specific results from these experiments are intended to help in determining optimum parameters for subsequent processing, maximum retention of radionuclides, and minimum vaporization of HVPM elements. 


\section{BACKGROUND}

The RWMC contains over 50,000 metric tons of low-level and TRU-contaminated wastes in addition to contaminated soil in the Subsurface Disposal Area (SDA) and the Transuranic Storage Area. The RWMC radioactive wastes also contain a variety of toxic materials and HVPMs requiring them to be designated as "mixed wastes." Treatment of these wastes for disposal is expected to be necessary in to meet Environmental Protection Agency (EPA) land disposal restrictions and Department of Energy (DOE) disposal requirements.

A high-temperature thermal treatment process (involving arc or plasma torch melters) for dealing with the INEL mixed wastes has been evolving from preliminary buried waste system design studies ${ }^{1,2}$ and stored waste system design studies. ${ }^{3}$ This approach for treating TRU contaminated waste results in an IEB final waste form. Previous research performed with IEB has shown that this waste form is long lived., ${ }^{4,5}$ Present waste form research at the INEL is focused on the improvements attainable with zirconium and titanium additives. ${ }^{7,8}$ These studies have shown that titanium and zirconium may increase the longevity of the waste form by producing a durable ceramic phase (Zirconolite) within a glass matrix. The TRU elements form a solid solution in the crystalline phase that is locked into the glass matrix structure. ${ }^{9,10,11}$

Surrogate waste mixtures were used for the tests. The surrogate mixtures were prepared to simulate mixed wastes stored at the INEL RWMC. This simulation was consistent with a proposed treatment system in which the mixed wastes would be incinerated. Following incineration, the ash would be melted in an arc melter and then cooled to produce a solid monolith waste form.

The "average" TRU-contaminated waste stream at the R.WMC, after oxidization and removal of organics, is designated A- 0 . If $40 \mathrm{wt} \%$ soil has been added to this waste, it is designated A-40. The compositions of A-0 (100 wt\% waste) and A-100 (100 wt\% soil) are shown in Table 2.1. ${ }^{4}$ Calculated compositions for A-40 and A-80 are also included since they were the main waste form types used during the studies. The resulting slag waste form for A40 is a basalt-like composition with increased iron, hence called iron-enriched basalt or IEB. The addition of oxides of elements $\mathrm{Zr}$ and Ti from Group IV of the Periodic Table produces additional minerals in IEB. These $\mathrm{Ti} / \mathrm{Zr}$ minerals have an affinity for actinide elements. IEB modified in this manner is called IEB4. ${ }^{12}$ The amount of $\mathrm{Zr}$ and Ti oxides used in the experiments was generally $10 \mathrm{wt} \% \mathrm{TiO}_{2}$ and $5 \mathrm{wt} \% \mathrm{ZrO}_{2}$, although this occasionally varied. Designations, such as IEB/A-40, IEB4/A-40, etc., are used to identify waste form compositions. Obviously, a composition such as IEB/A-100 (soil) is not really iron-enriched (see Table 2.1), but these designations will still be used as a matter of convenience. 
Table 2.1 Weight percent compositions of the IEB series waste forms.

\begin{tabular}{|c|c|c|c|c|c|c|c|c|}
\hline & $\mathrm{SiO}_{2}$ & $\mathrm{Al}_{2} \mathrm{O}_{3}$ & $\mathrm{FeO}_{-} \mathrm{Fe}_{2} \mathrm{O}_{3}$ & $\mathrm{CaO}$ & $\mathrm{MgO}$ & $\mathrm{Na}_{2} \mathrm{O}$ & $\mathrm{K}_{2} \mathrm{O}$ & $\mathrm{TiO}_{2}$ \\
\hline $\mathrm{A}-0$ & 38.0 & 7.4 & 34.5 & 8.3 & 4.6 & 4.8 & 2.4 & - \\
\hline $\mathrm{A}-40$ & 51.0 & 10.2 & 19.5 & 9.7 & 3.5 & 3.2 & 2.6 & 0.3 \\
\hline $\mathrm{A}-80$ & 60.4 & 12.0 & 9.4 & 9.9 & 2.8 & 2.2 & 2.8 & 0.5 \\
\hline $\mathrm{A}-100$ & 65.4 & 13.0 & 4.5 & 10.2 & 2.4 & 1.7 & 2.9 & 0.6 \\
\hline
\end{tabular}

Oxides of metals commonly found in INEL soil, such as $\mathrm{Si}, \mathrm{Al}, \mathrm{Fe}, \mathrm{Ca}$, and $\mathrm{Mg}$, will be dissolved in the melt and retained in oxide form. Previous studies have indicated that retention of the TRU/U surrogates $\mathrm{Ce}, \mathrm{Gd}, \mathrm{Nd}$, and $\mathrm{Sm}$ is high. ${ }^{7}$ The influence of these reactions on the behavior of the HVPMs, such as $\mathrm{Pb}, \mathrm{Cd}, \mathrm{Cr}$, and $\mathrm{Zn}$, however, is less certain. Oxidation, dissolution, and retention of the metals in the melt are desirable. The focus of this work was to determine the extent of partitioning of the metals between the gaseous and solid products. This study collected and analyzed both solid and gaseous residues to determine the partitioning behavior of each of the above elements. This information will be correlated as a function of surrogate and HVPM waste feed content and process temperature. 


\section{ARC MELTER DESCRIPTION AND HISTORY}

The primary justification for building the small arc melter was to investigate the synthesis and properties of IEB4 formed in an arc processing environment. Additionally, it . was important to study arc heated melter characteristics and processing capabilities and to determine development requirements for a waste processing demonstration facility.

\subsection{Original Arc Melter}

The first generation arc melter, built and tested during in 1992, consisted of a watercooled stainless steel crucible with dual carbon electrodes attached to water cooled holders. The arc melter operates in DC mode with two graphite electrodes maintaining an arc just above the melt. The electrode feed-throughs into the melt chamber are insulated. The crucible consisted of an outer stainless steel housing into which an inner crucible fit. A rubber o-ring sealed the crucible so cooling water could flow between the outer housing and the inner stainless steel crucible. The easily removable stainless steel insert allows fast turnover during batch operations. The entire crucible was surrounded by a large water-cooled chamber to which the electrode support and drive motors were attached. Tests were conducted to investigate various system operational parameters and capabilities. The arc melter operates in direct current mode utilizing two $60 \mathrm{~kW} \mathrm{DC} \mathrm{power} \mathrm{supplies} \mathrm{controlled}$ manually. The overall capacity of the melter is approximately $20 \mathrm{~kg}$ with a maximum power input of about $40 \mathrm{~kW}$. In normal operation, the electrodes are close to the melt, with short

arcs occurring between the electrodes and the melt. The operator monitors the position of the electrodes through portholes in the top of the melt chamber. The melter operates in a predominantly Joule-heating mode with current passing through the relatively high resistance melt. The arc gaps above the melt are constantly adjusted via stepper motors to maintain stable operation. A complete description of this first generation arc melter and the tests that were conducted can be found in an earlier report. ${ }^{13}$

\subsection{FY-93 Arc Melter Modifications}

The arc melter underwent substantial modifications in FY-93. The large outside chamber was discarded and replaced by a lid fitting directly on top of the water-cooled crucible creating a small melt chamber within the water-cooled crucible. This change was made primarily to ensure a tight seal in the melter and exhaust system so fumes would not escape during tests with HVPMs in the melt. The lid included two sealed viewing ports plus other penetrations for thermocouples, pressure transducers, etc. A separate support stand was built to hold the electrodes, connectors, and drive motors in addition to the crucible lid. The crucible itself was supported by a hydraulic lift table which could be raised up to the crucible 
lid to seal the system or lowered to provide access to the removable inner stainless steel crucible. The data logger system was retained as the primary data recording device. Information on cooling water flows and temperatures, input power, exhaust temperature, etc. were automatically transmitted from the datalogger to a personal computer and saved during arc melter operation.

Also added to enhance operability were other major system elements such as a control and monitoring console, video monitoring and recording equipment, two-color infrared pyrometer, auger feeder, gas flow control and monitor system, and baghouse filter system. Operability improvements were attained by modifying the electrode drive system to include separate stepper motor control of the anode to compensate for its higher erosion rate. A stickmounted thermocouple that could be inserted into the slag for a temperature measurement and then withdrawn before being damaged or melted also improved the system's capability. A photograph of the system, as modified for FY-93, is presented in Figure 3.1. Additional detail about this arc melter facility can be found in previous reports. ${ }^{14}$

Specialized equipment used for specific testing series included a Method 5 exhaust gas sample train and a slag sampling system used during the volatilization studies. A watercooled air/oxygen lance was used during the redox tests. Figure 3.2 shows a schematic of the arc melter system as configured for the FY-93 volatilization tests.

Surface temperature measurements of the melt were made using the optical pyrometer which can be seen in Figure 3.1 mounted to the right of the electrode assembly. Resistance temperature detectors (RTDs) are installed to measure heat losses to the chamber, crucible cooling water, electrodes, and off-gas. Type ' $C$ ' immersion thermocouples (TCs) are used to monitor slag temperature. The TCs, RTDs readings, arc voltage, current, and water flows are recorded with time on a data logger system. Gas flow rates are monitored by an MKS M062-LS06E mass flow valve and an MKS 440 series mass flow controller. An ice cold trap was used to condense water vapor and cool exhaust gases before entering the baghouse. The high-efficiency baghouse filter collects condensed and solid particulate before the exhaust gas passes through a HEPA filter and into the building exhaust system. 


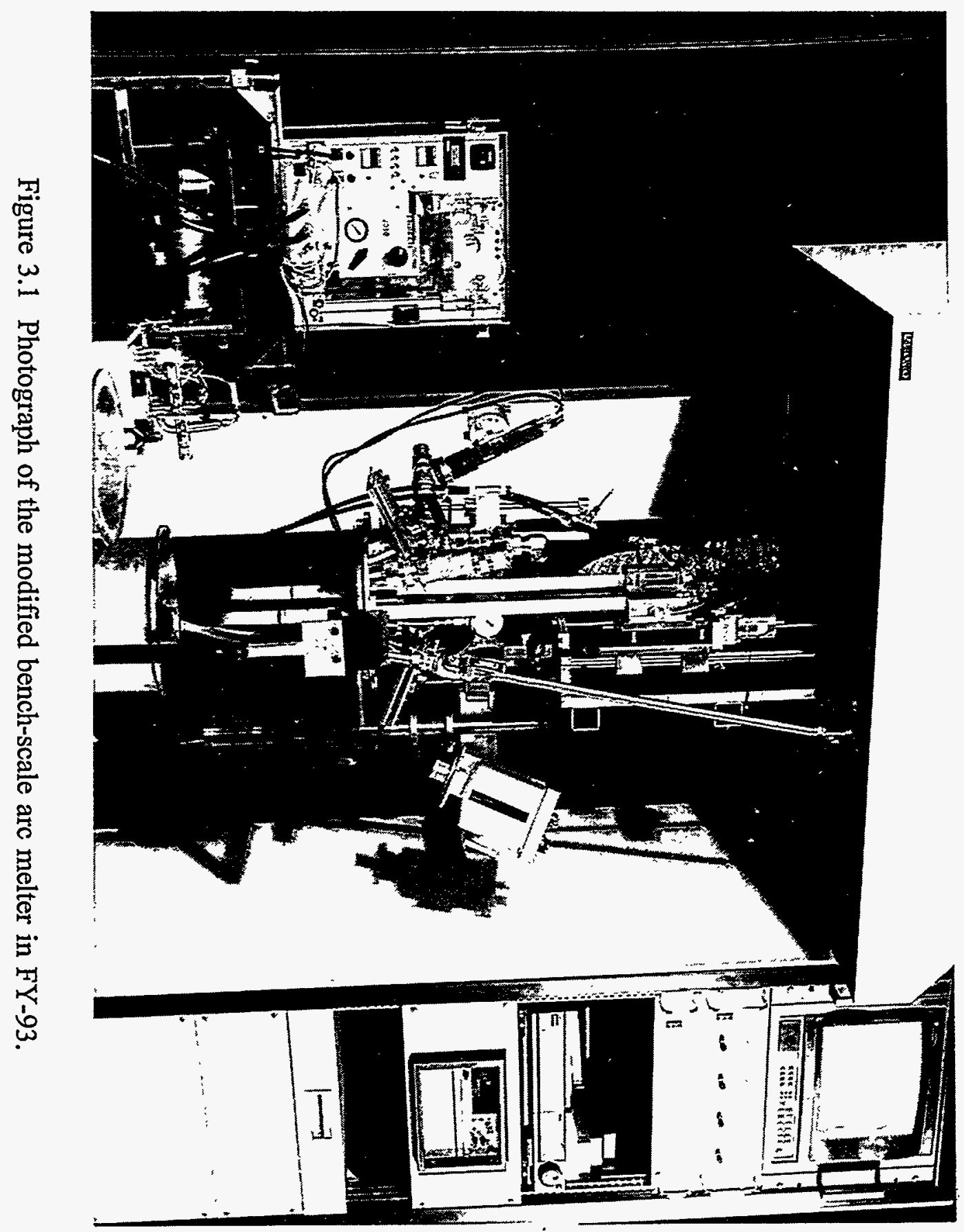




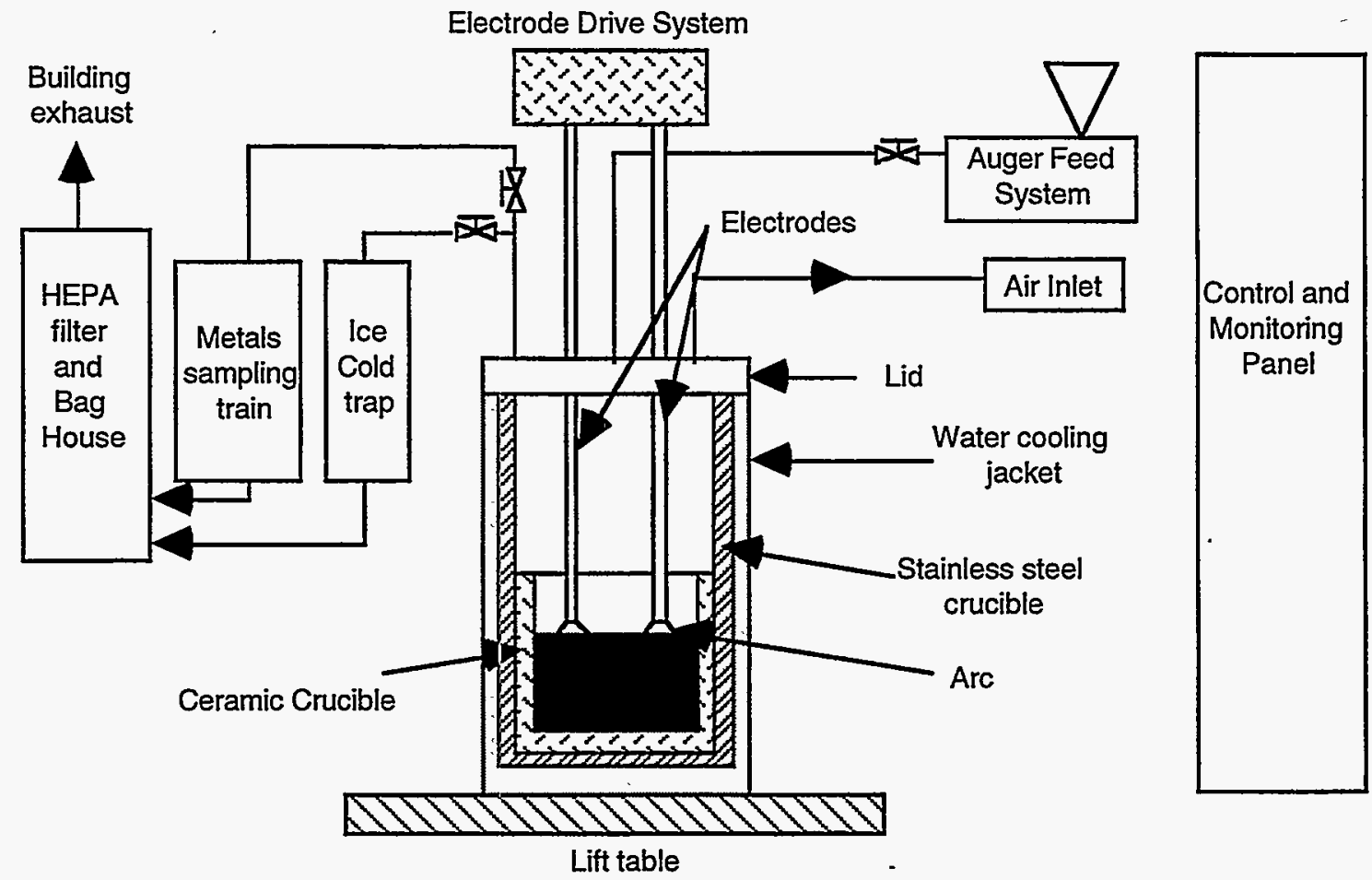

Figure 3.2 Schematic of the modified bench scale arc-melter . 


\subsection{FY-94 Arc Melter Modifications}

The purpose of the FY-94 HVPM tests was to determine methods to retain surrogates (HVPM, Cs, and TRUs) in the final waste form (IEB4/A-40). Many modifications to the arc melter were made to ensure that useful data could be obtained. Most important, the exhaust system was entirely rebuilt so that particulate could be easily collected and an accurate mass balance attained. Further changes included improvement of the electrode penetration seals in the lid of the melter, development of a pinhole viewing device to observe the melt and arcs in dusty conditions, installation of a graphite feed chute to better control introduction of material into the furnace, and construction of a water-cooled lance to inject air or oxygen into a melt. Figure 3.3 shows the arc melter system as configured for the FY-94 tests.

In order to analyze HVPM retention, quantitative mass balances were needed during melter operations. A procedure was developed to measure all input and output materials and thus ensure an accurate mass balance. Of particular importance, the arc melter exhaust system was modified to provide for easy material collection. The new exhaust system, presented in Figures 3.4 and 3.5, was redesigned and built to allow easy assembly, access for cleaning, and particulate collection, which facilitated mass balance accountability within the melter system.

Additionally, the new exhaust system was modified to prevent blockages that were experienced during the FY-93 tests. The size of the exit port was increased and the 90-degree exit line was replaced with one having a gradual radius. Downstream, the exhaust line also included an air dilution nozzle and eductor to provide extra motive force for maintaining negative pressure in the melt chamber and gas cooling. A type ' $\mathrm{K}$ ' thermocouple inserted upstream of this nozzle monitored the exhaust gas temperature. A cyclone separator was installed downstream of the nozzle for particle collection. A removable Watman quartz microfiber filter ( $8 \times 10$ inches) was placed in the exit gas stream prior to the baghouse to collect the remainder of entrained particulates and provide for mass balance closure. These filters are rated to retain $99.997 \%$ of particles $0.3 \mu \mathrm{m}$ in size at flows up to $1000 \mathrm{slpm}$. Isolation and bypass valves were installed around the filter so the filter could be replaced during operation. The loading condition of the filter was determined by a Magnehelic $\otimes(0-10$ inches of water) differential pressure gage installed across the filter. The filter is determined to be loaded with particulate when the pressure gage reads 5 inches of water. 


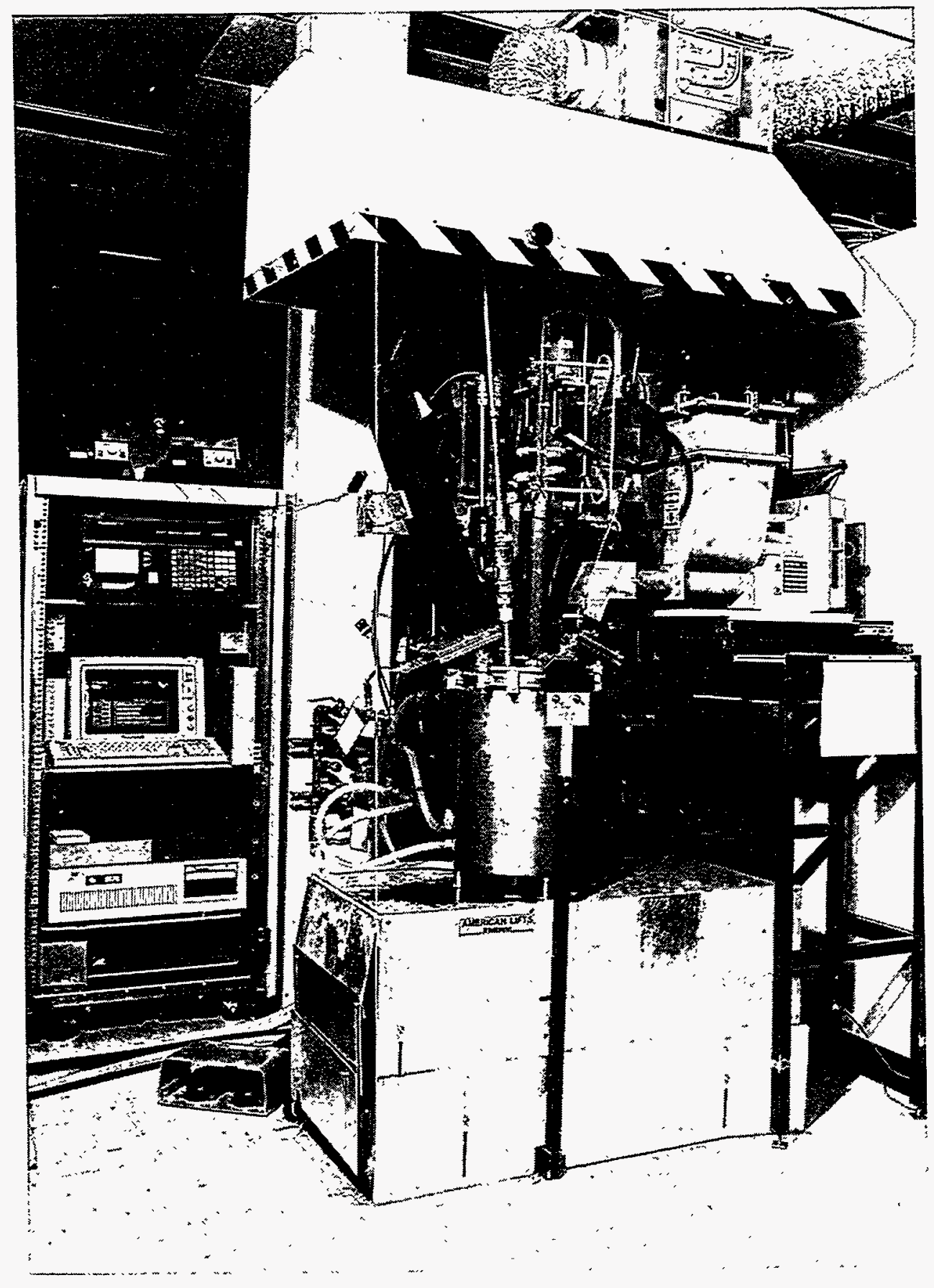

Figure 3.3 Photograph of the arc melter system as configured for the FY-94 tests. 


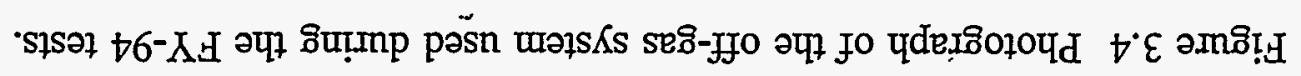

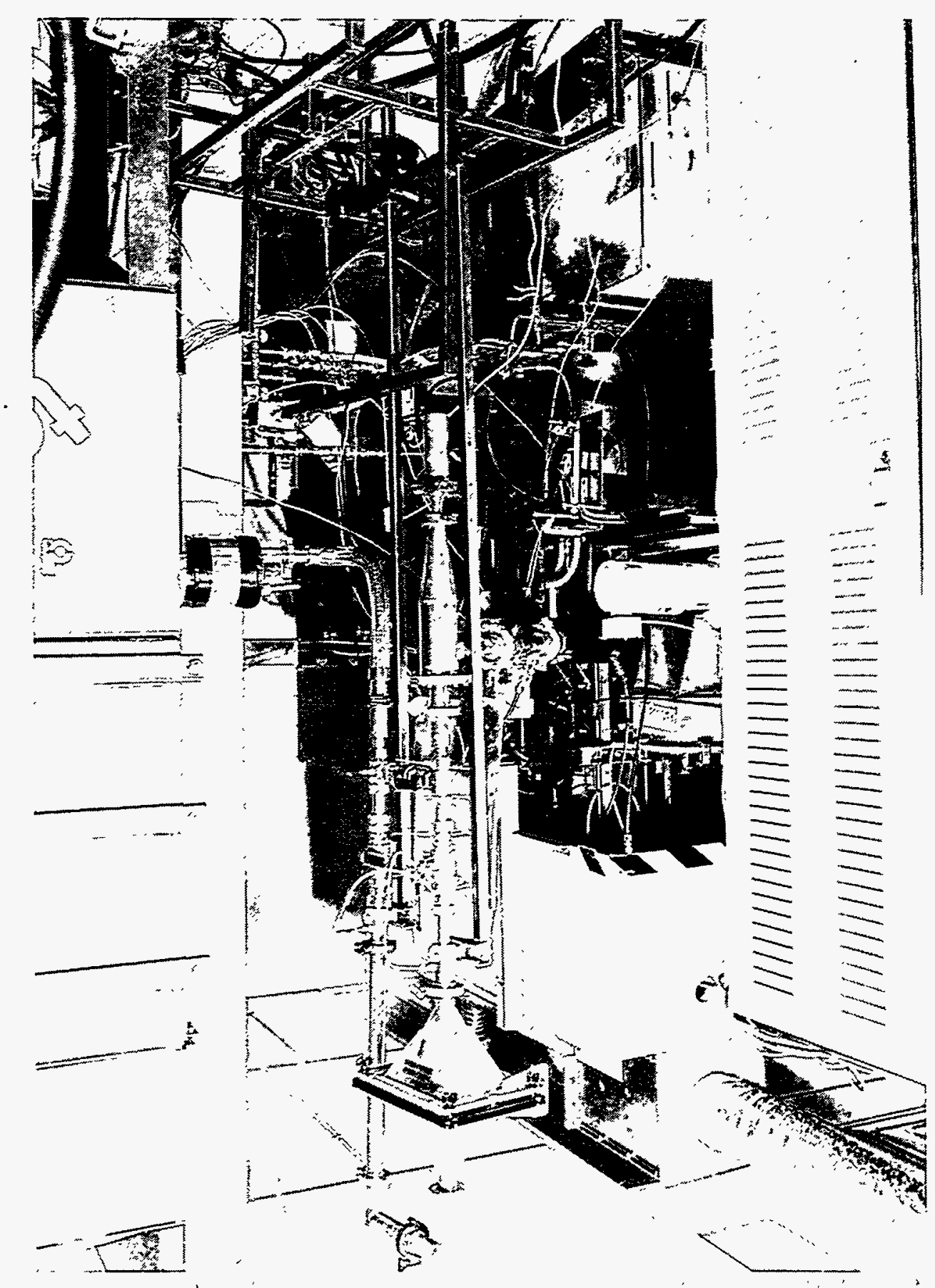




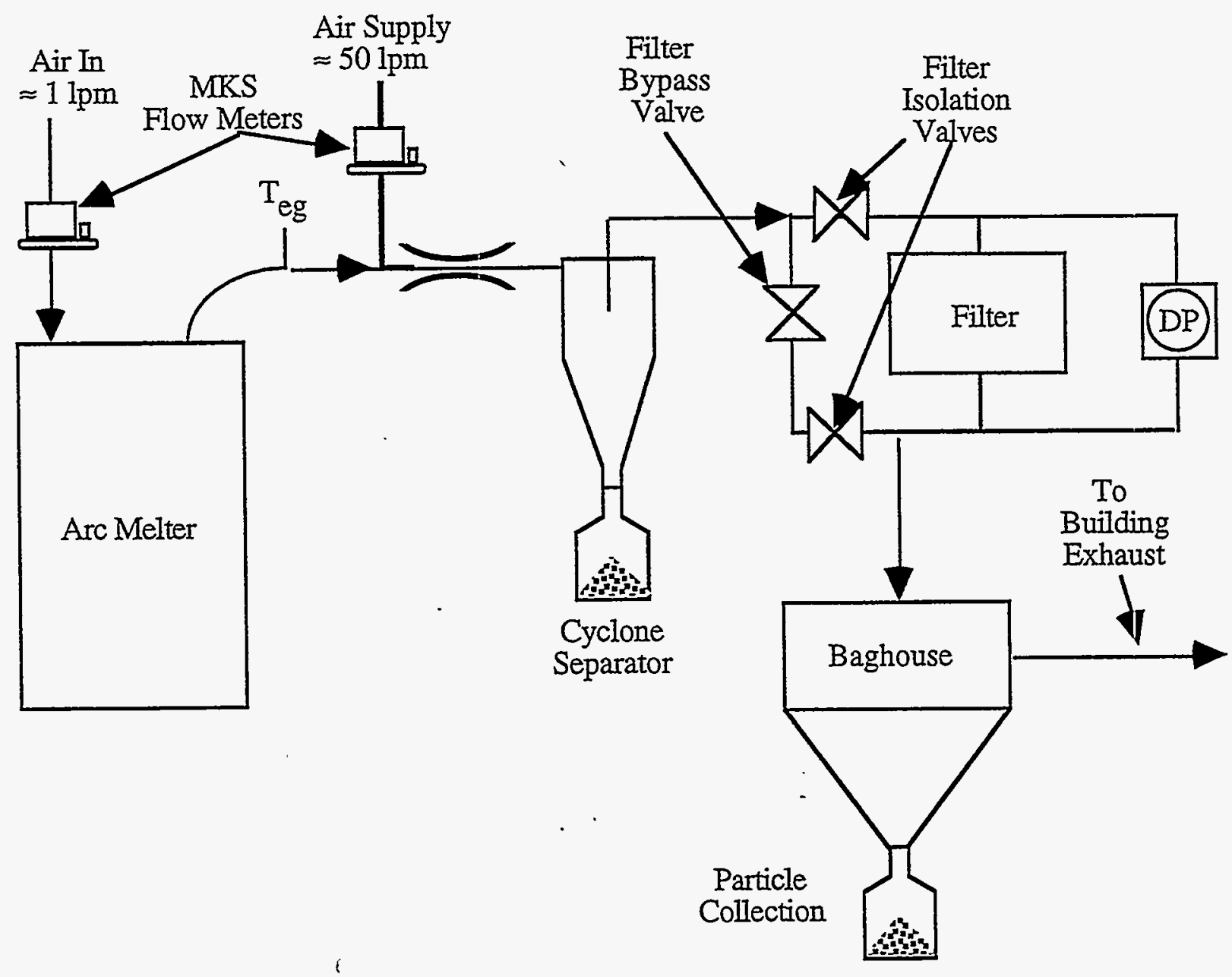

Figure 3.5 Schematic diagram of the modified offgas system utilized during the FY-94 tests. 
The sealing system on the arc melter was upgraded to ensure negative pressure in the melt chamber for extended operations. The boron nitride (BN) electrode seals, used previous to FY-94, exhibited poor wear characteristics. The replacement seals, constructed of micarta (a resin-bonded fiber board), are shown in the schematic in Figure 3.6. The micarta seal and rod wiper assembly improved operation of the electrode motion while providing excellent sealing. A small piece of $B N$ attached to the bottom of the micarta seal was required for thermal protection. The electrodes themselves were provided with individual drive mechanisms along with a master drive as shown schematically in Figure 3.7.

The feed system was modified to allow for installation of a graphite downcomer or feed chute that would direct material onto the top of the melt. Figure 3.8 shows the relative position of the feed tube, graphite extension, carbon steel starter ring, and soil mixture. Also shown in Figure 3.8 is the new cooling system used for the FY-94 tests.

The control of the melter through visual observation of the electrode arcs was critical in determining the existence of a cold cap and position of the electrodes relative to the melt surface. A pinhole camera assembly (see Figure 3.9) was incorporated into the viewing system to permit an unobstructed view of the melt surface for monitoring the arcs and cold cap. The pin-hole camera eliminated the need to constantly clean the porthole windows as required when viewing the melt directly through the portholes. 


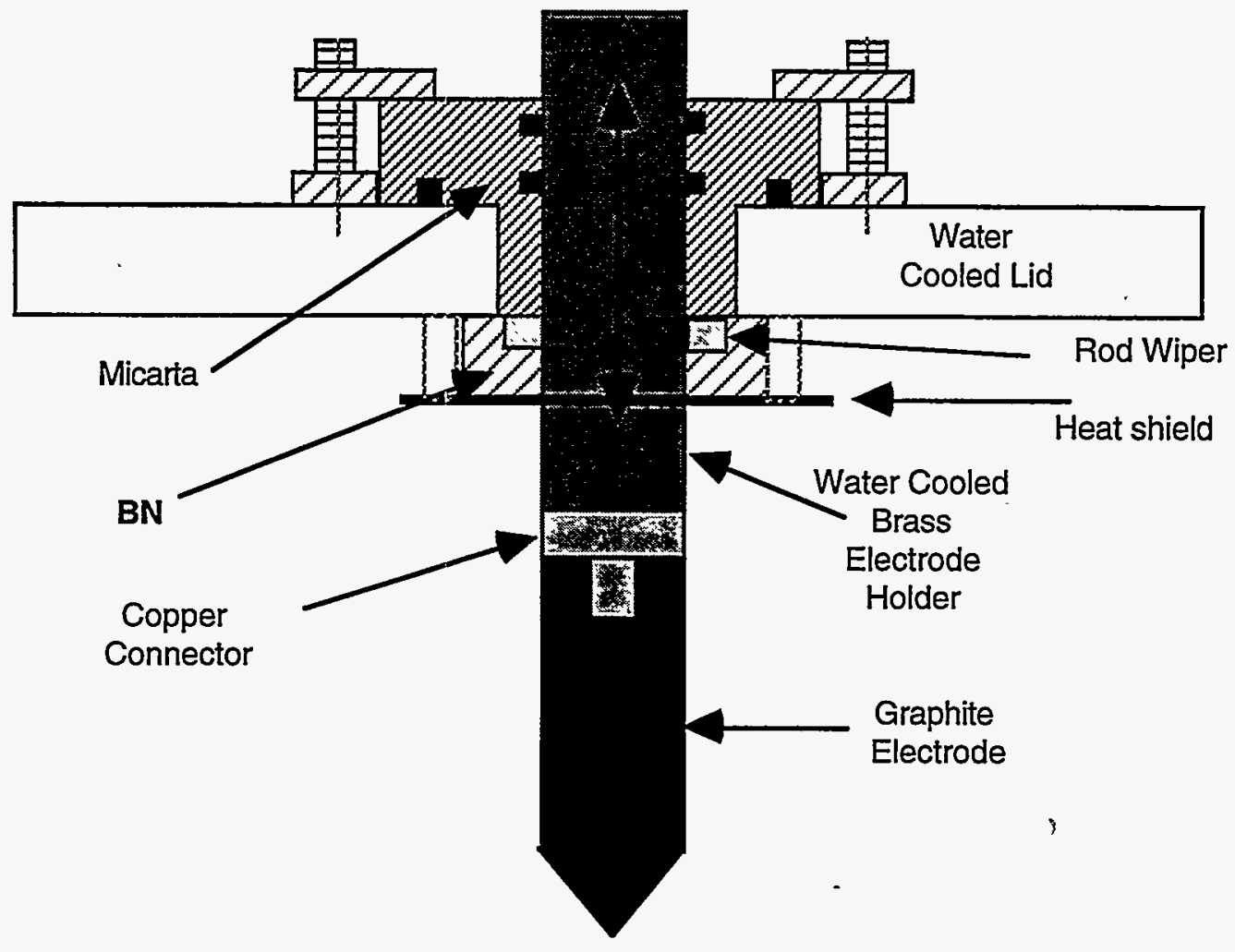

Figure 3.6 Micarta seal and rod-wiper assembly used for the electrodes during FY-94. 


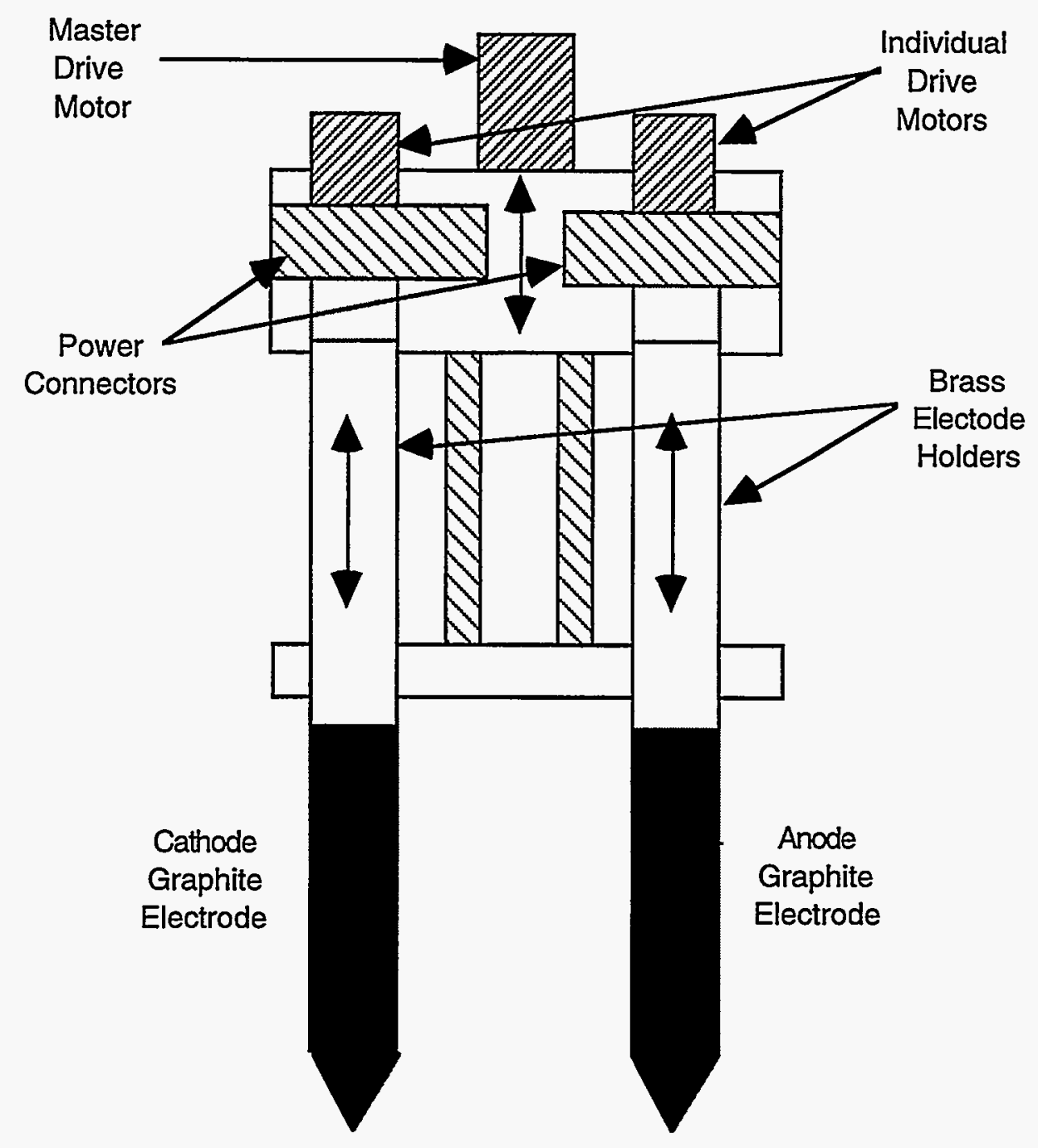

Figure 3.7 Schematic of the modified electrode drive mechanism showing the individual drive motors and master drive motor. 


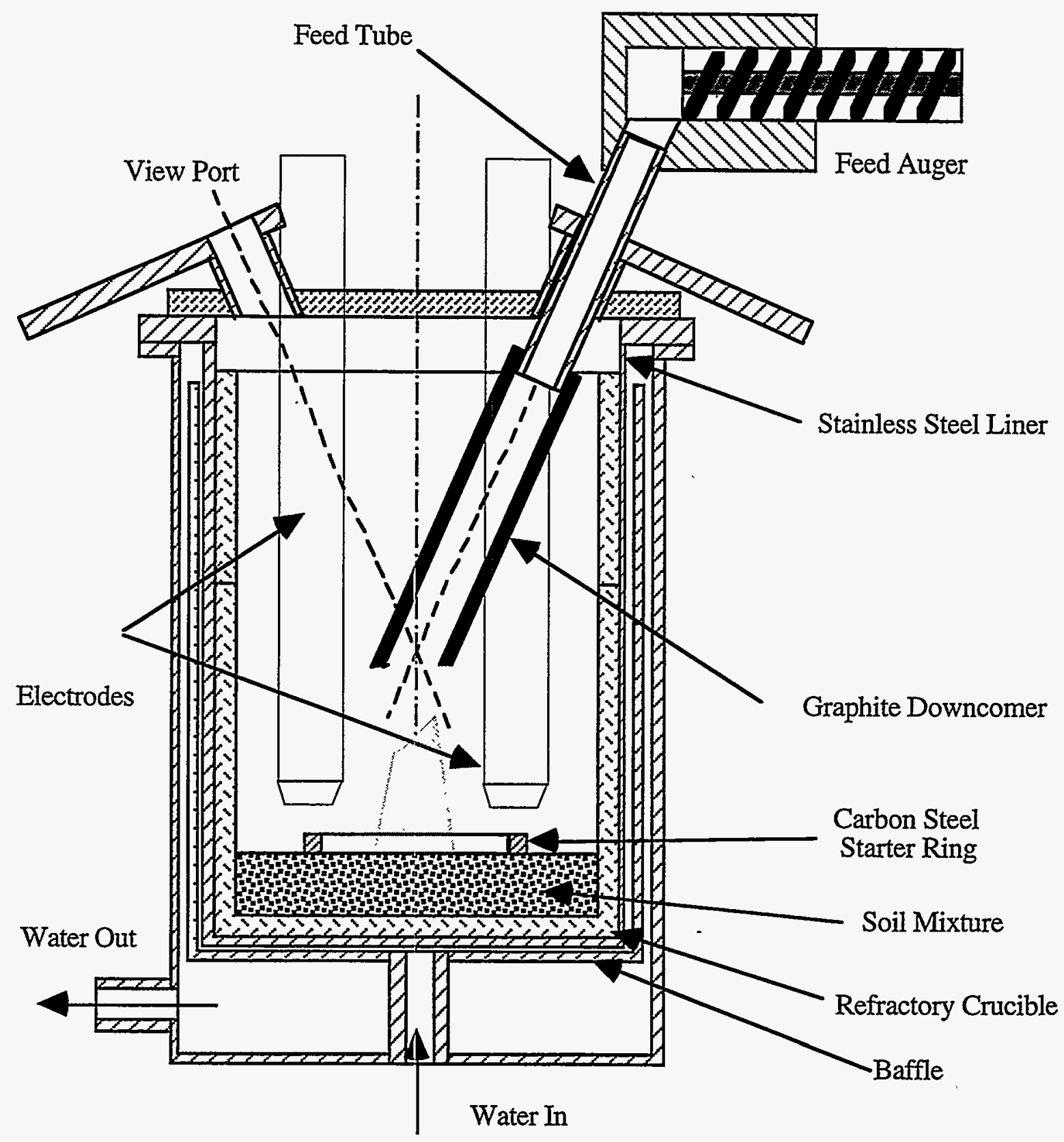

Figure 3.8 Schematic of the modified arc melter crucible assemble showing the material feed system used during FY-94. 


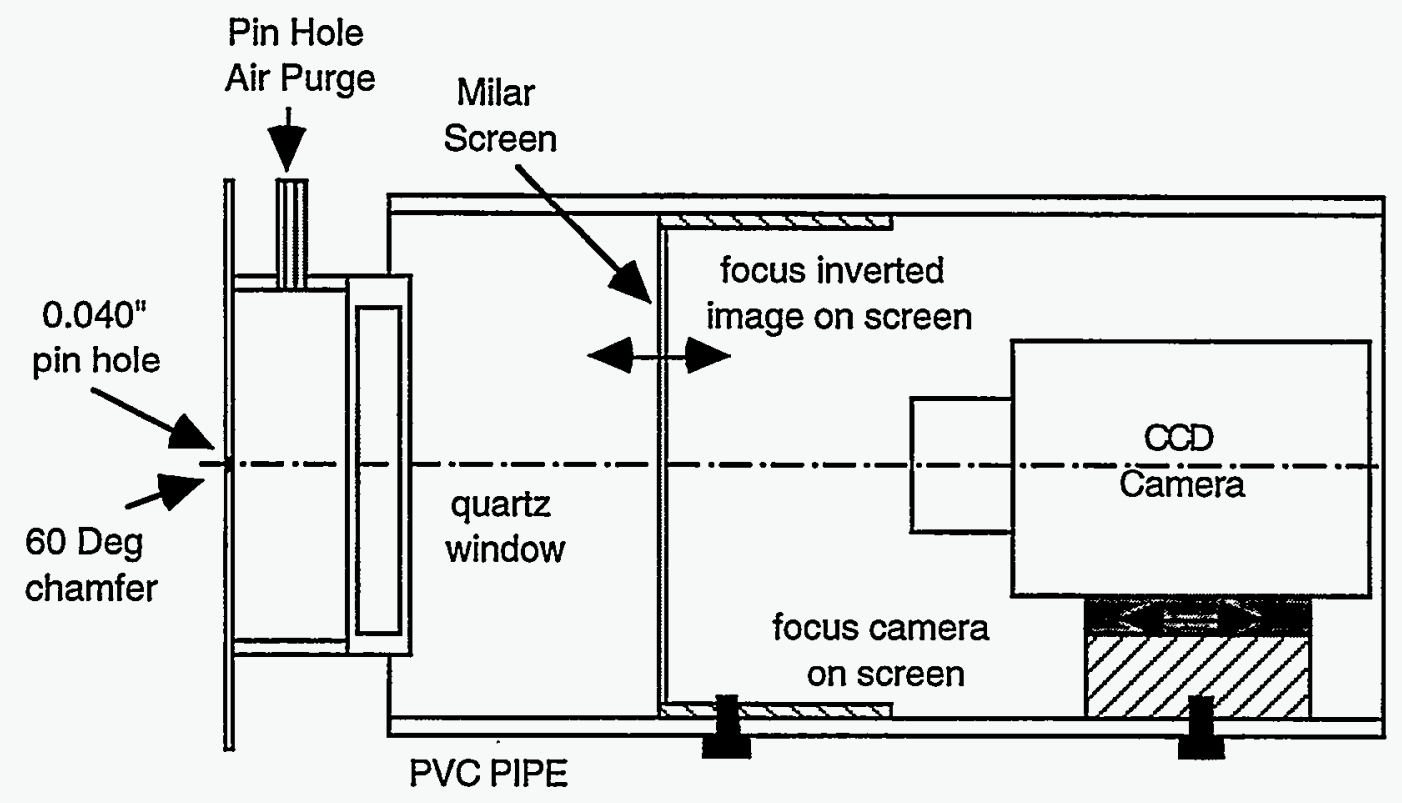

Figure 3.9 Schematic of the pin-hole camera assembly used during the FY-94 tests. 


\section{ARC MELTER OPERATIONS}

\subsection{Introduction}

During the various experimental campaigns, several aspects of melter operation were found to be important, including the energy balance during arc melter operation, carbon electrode erosion, and melt temperature monitoring. Electrode erosion is problematic because it limits the duration that the arc melter can be operated. Temperature measurements on the slag were challenging due to sometimes high $\left(>2000^{\circ} \mathrm{C}\right)$ temperatures.

The general routine in all melter operations consisted of weighing the electrodes and mounting them onto the electrode drive mechanism. All thermocouples, water flow meters, and voltage probes were set in place, including those inside the crucible, and operationally checked and calibrated. An initial charge of soil/waste mixture was loaded into the crucible and the system secured. When the crucible cover is closed and sealed, a cooling water leak check is performed prior to starting the arc melter.

\subsection{Arc Melter Operation}

Two $80 \mathrm{~kW}$ power supplies were used to run the arc melter. A thin carbon strip or a metal ring was placed in the initial charge material to provide a current path to start the melting process. When melt pools beneath the electrodes coalesced providing a current path through molten slag, joule heating in the slag would increase energy input into the melt. After the startup phase and the electrodes have been adjusted to a stable operating position above the slag (approximately one-half inch), power input to the melt is controlled primarily by decreasing or increasing the current. The typical operating voltage is $180 \mathrm{~V}$, although this may vary somewhat depending upon the material being melted. Melting soil, rather than an A-40 mixture for example, will typically result in an operating voltage of over $200 \mathrm{~V}$. The arc melter is normally operated between 10 and $40 \mathrm{~kW}$ with the current at 50 to $200 \mathrm{~A}$.

\subsection{Energy Balance}

An understanding of the energy or heat balance of the system is critical to operating the arc melter. During the FY-93 tests, the arc melter was difficult to control when the viewport windows became covered with dust obstructing the operator's view of the electrodes above the melt. Also excessive foaming of the melt caused by gaseous evolution sometimes made control difficult. Control was improved during FY-94 with the addition of a pin-hole camera. During FY-94 less material was preloaded into the crucible for startup, which substantially reduced problems related to foaming during the initial melt stage. It should be 
noted that nearly all the materials are already in oxide form and inert, and therefore in all of these tests, the amount of chemical energy supplied by the melt materials is neglible.

During volatilization experiments, changing conditions in the melter were evident from energy balance measurements. Crucible heat transfer calculations are given elsewhere. ${ }^{13}$ Voltage and current traces with time can also be informative. The energy balance discription for the FY-93 tests was described by T. L. Eddy et al. ${ }^{13}$

Examples of energy balance data are presented in Figures 4.1-4.4. Figure 4.1 shows the input energy data for the FY-94 cold cap run ARM090894. Compare this data with the the curves in Figure 4.3, ARM092094 a run without a cold cap. During the cold cap run the power input was generally under $20 \mathrm{~kW}$ and lasted only 66 minutes where the run without a cold cap operated over $20 \mathrm{~kW}$ for 89 minutes to process the same amount of material. The difference in melt time and power levels can be attributed mainly to the insulating effect of the cold cap. In both cases, the molten slag was maintained at about $1600^{\circ} \mathrm{C}$. For all the FY-94 runs it took about 20 minutes to achieve a fully molten surface with slag temperature at $1600-1700^{\circ} \mathrm{C}$. The "power out" traces shown in Figures 4.2 and 4.4 reveal the difference in operating with and without a cold cap. Although they are similar in that they both level off at 21-22 minutes into the run, the 'power out' trace in Figure 4.3 is almost equal to the 'power in' trace. This indicates energy is being removed from the melt via the water-cooled crucible almost as fast as it is being supplied, thus the increased amount of time required to completely melt the material. Since the melt is open, heat energy can quickly radiate away from the surface of the melt. The larger difference between "power in" vs. "power out" in Figure 4.2 shows that significantly more energy is being supplied to the melt in this case, thus the reduced amount of time necessary to melt it. The cold cap prevents heat energy from radiating away. Only near the end of the run after 60 minutes does the amount of energy being lost increase, indicating that the cold cap has completely melted. 


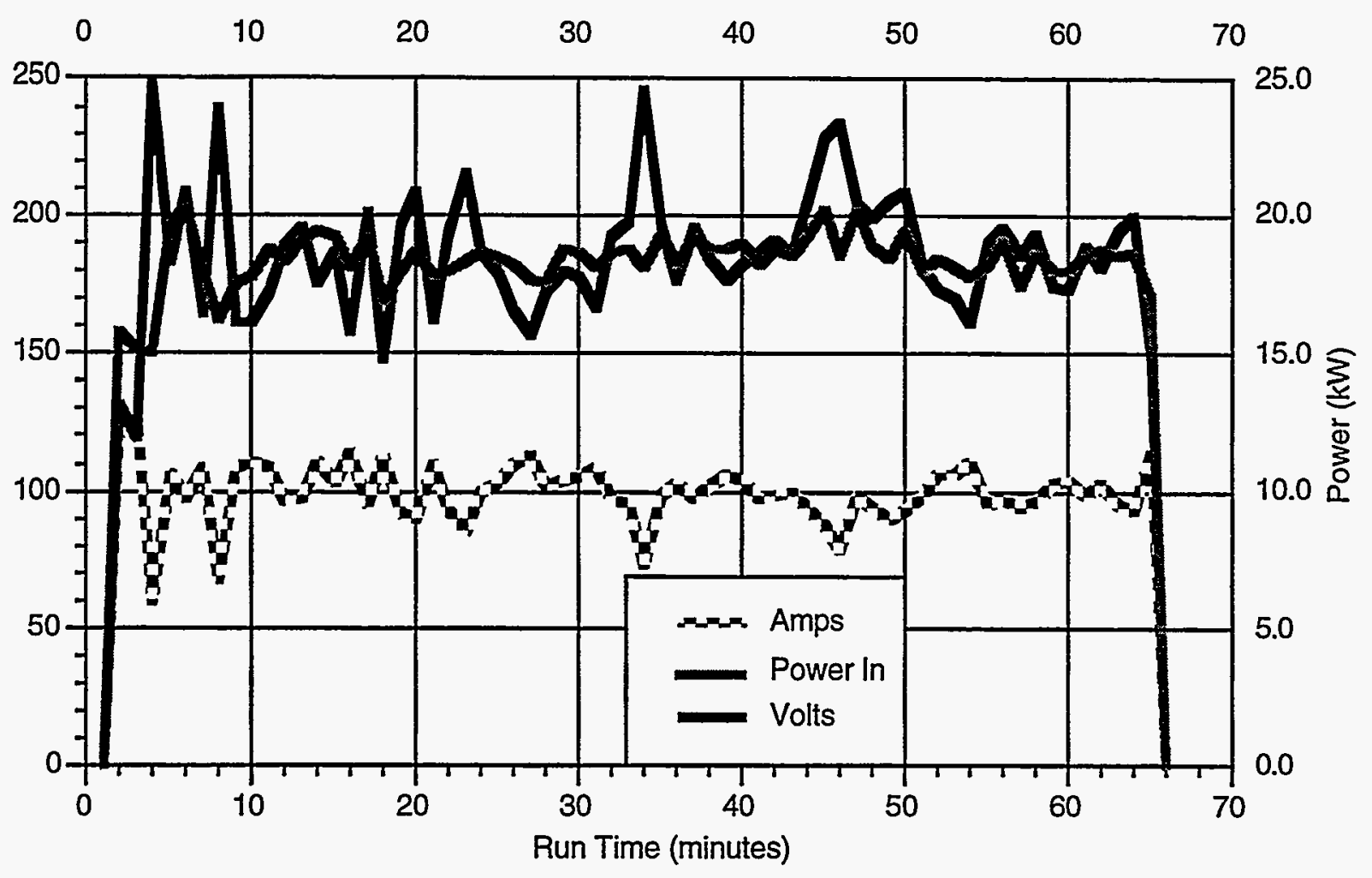

Figure 4.1 Energy input data for the HVPM run ARM090894 with a cold cap.

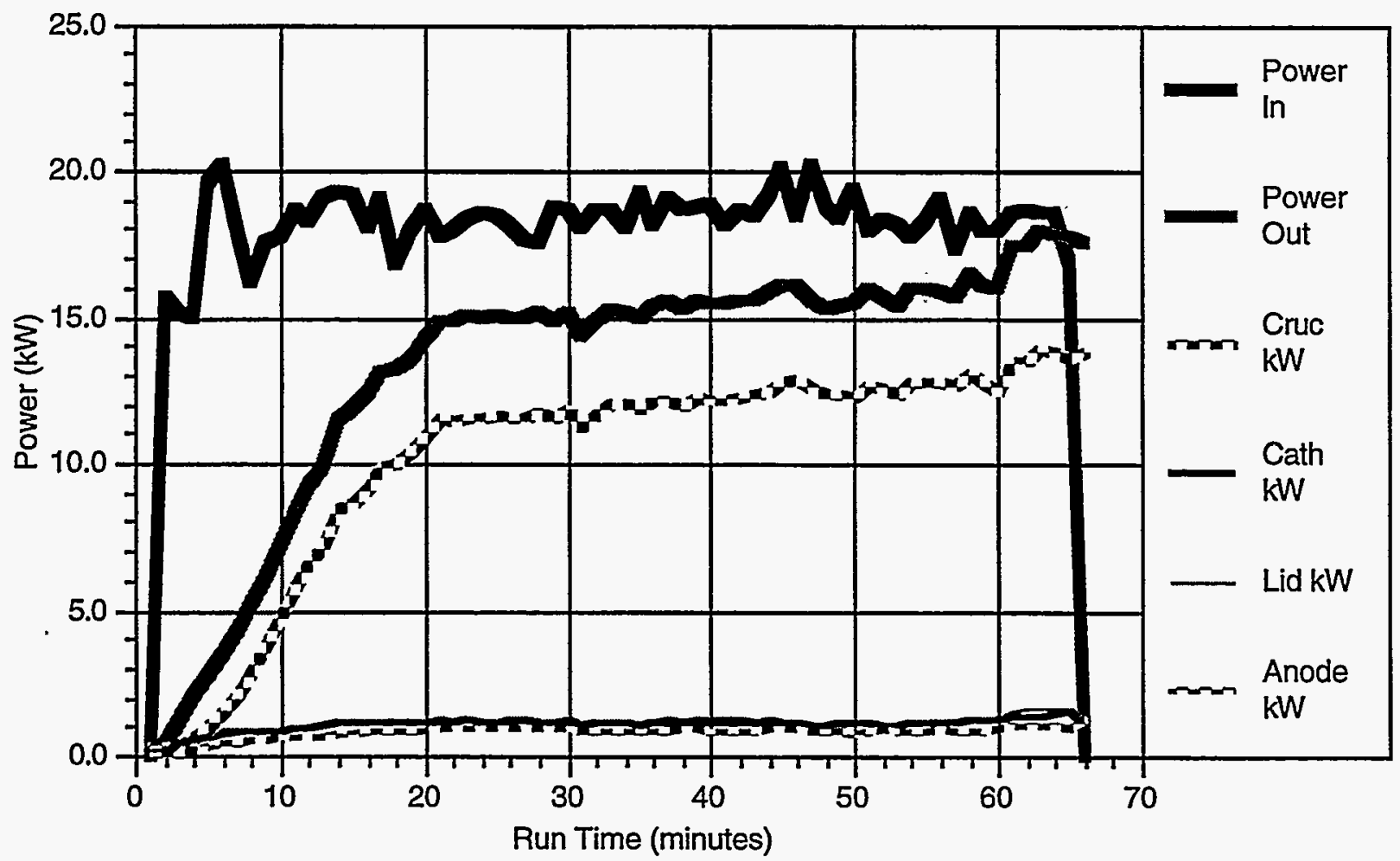

Figure 4.2 Energy balance information from HVPM run ARM090894 with a cold cap. 


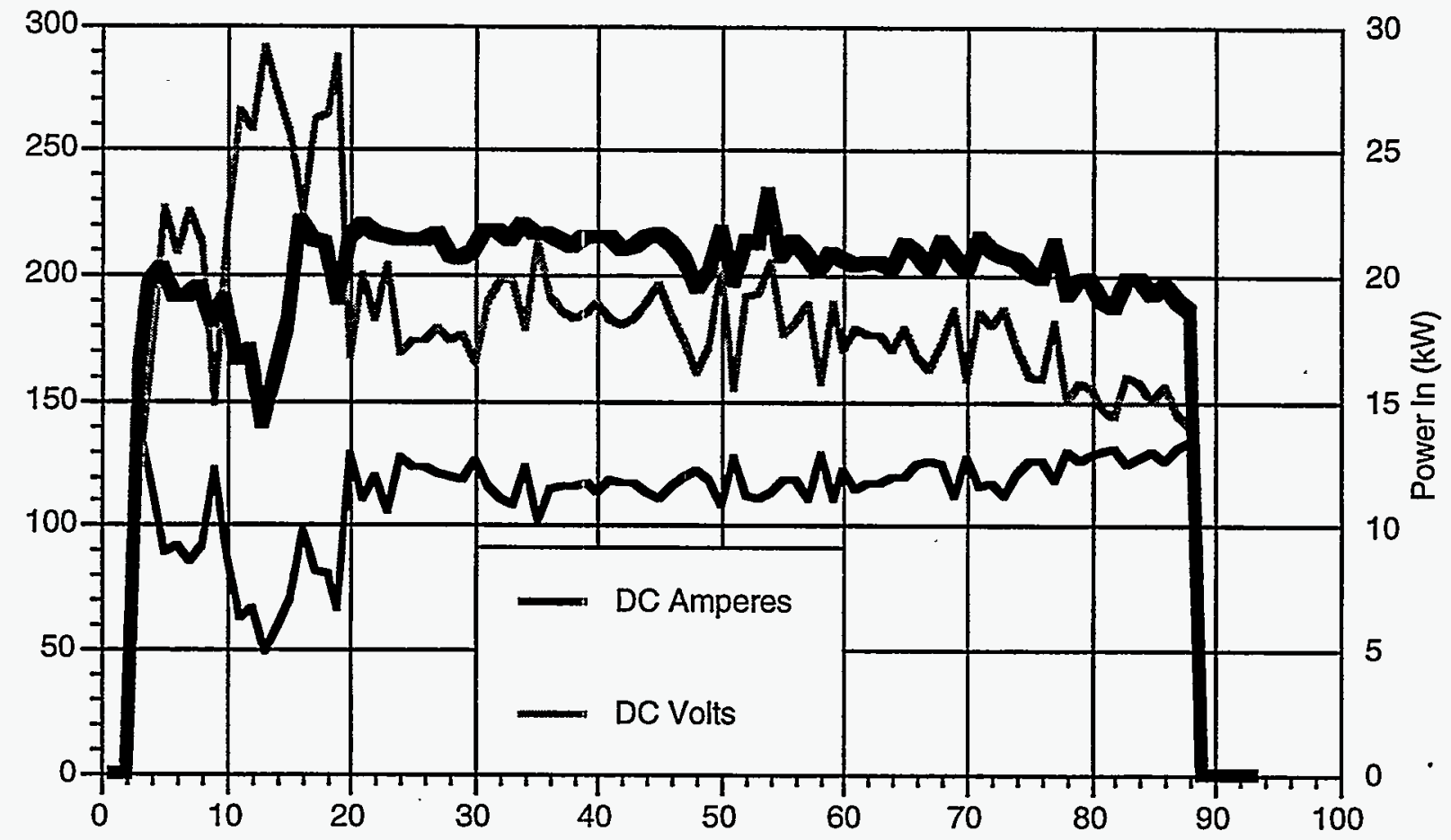

Figure 4.3 Energy input data for the HVPM run ARM092094 without a cold cap.

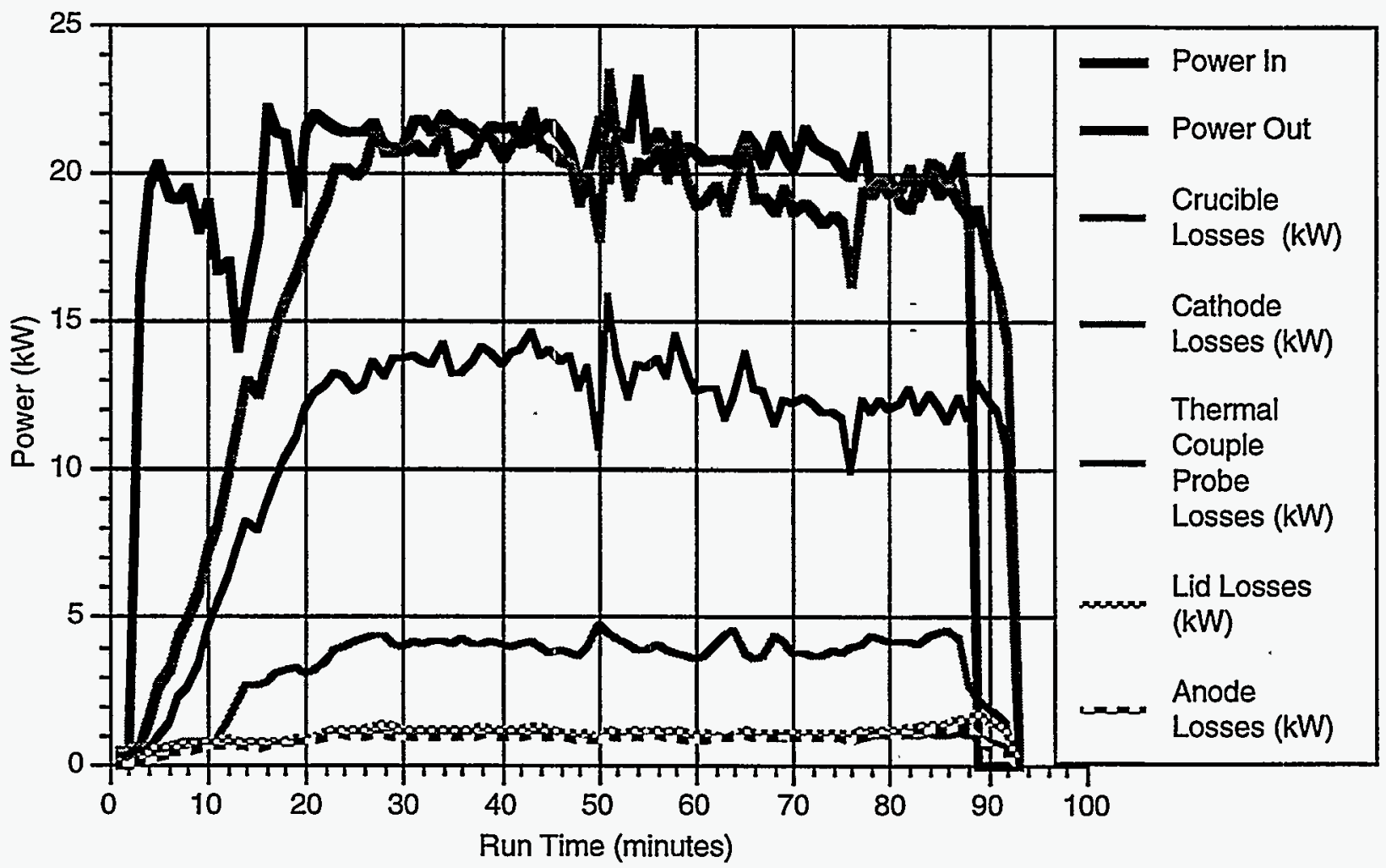

Figure 4.4 Energy balance information from HVPM run ARM092094 without a cold cap. 


\subsection{Electrode Erosion}

Graphite electrode erosion is one of the factors that limit the operating time of the arc melter. In Tables 4.1 and 4.2, data from the FY-93 volatilization and redox experiments and FY-94 volatilization experiments show that the anode consumption rate is 25 to $50 \%$ higher than that of the cathode most of the time. During FY-93 tests, all the electrodes were coated with 0.060 inches of zirconia to inhibit erosion. Previous work had shown that zirconia coating reduced electrode erosion. ${ }^{13}$ During FY-94 two types of silicon based coating were used: a paint on silicon carbide (ZYP Coatings, Inc., $48 \% \mathrm{SiC}$ ) coating and plasma sprayed silicon coating applied through the Vartech company. Although, the anode is consumed faster than the cathode (about 2 to 1), without information about arc length or submerged arc, it is difficult to formulate a relationship between power input, temperature, chamber atmosphere (redox conditions), and electrode erosion rates.

Figure 4.5 shows that electrode erosion rate (in grams per amp-hr) when using the cold cap is, in general, higher than that without the cold cap. Electrodes submerged in a cold cap erode faster than electrodes held above a liquid melt in the case without a cold cap because they are in contact with the reactive slag. Except for the oxidizing run \#OX03A, where excessive foaming stopped the run, the erosion or loss rates for all electrodes were very similar.

It was observed that the noncoated and ZYP SiC coated electrodes were consumed differently from the $\mathrm{ZrO}$ or Si coated electrodes. Noncoated electrodes and the ZYP SiC coated electrodes became pencil-shaped during the run indicating reaction with the graphite above the melt surface. Figure 4.6a, shows ZYP SiC coated electrodes from FY-94 cold cap run ARM082394, giving an example of the pencil-shaped wear. In Figure 4.6b, the plasmasprayed Si coated electrodes from FY-94 cold cap run ARM090894 show little evidence of reaction above the arc-affected zone, and the wear is more uniform from anode to cathode. The zirconia-coated electrodes used during FY-93 tests produced results similar to the plasmasprayed Si coating.

- During the FY-93 volatilization runs without the cold cap, it was difficult to see the position of the electrodes above the melt because of the dust. The cold cap material also made it difficult to observe the position of the electrodes and, therefore, to keep them just above the melt. Some initial oscilloscope measurements were made in an attempt to identify a signature related to electrode position, but they were inconclusive. During FY-94, a pinhole camera was used to observe the electrode arc gaps. This proved to be a useful tool, and 
Table 4.1 Operating conditions and electrode erosion data for the FY-93 experiments.

\begin{tabular}{|c|c|c|c|c|c|c|c|c|}
\hline Test & Time & $\begin{array}{c}\text { Ave } \\
\text { power } \\
(\mathrm{min})\end{array}$ & $\begin{array}{c}\text { Total } \\
(\mathrm{kW})\end{array}$ & $\begin{array}{c}\text { Anode } \\
\text { loss } \\
(\mathrm{g})\end{array}$ & $\begin{array}{c}\text { Cathode } \\
\text { loss } \\
(\mathrm{g})\end{array}$ & $\begin{array}{c}\text { Anode } \\
\text { loss rate } \\
(\mathrm{g} / \mathrm{A}-\mathrm{h})\end{array}$ & $\begin{array}{c}\text { Cathode } \\
\text { loss rate } \\
(\mathrm{g} / \mathrm{A}-\mathrm{h})\end{array}$ & $\begin{array}{c}\text { Max. } \\
\text { slag } \\
\text { temp } \\
\left({ }^{\circ} \mathrm{C}\right)\end{array}$ \\
\hline
\end{tabular}

Volatility tests without cold cap (IEB4/A-80 and IEB4/A-40)

\begin{tabular}{|c|c|c|c|c|c|c|c|c|}
\hline HVPM01 & 169 & 15.7 & 230 & 73.2 & 43.3 & 0.32 & 0.19 & 1460 \\
\hline HVPM02 & 125 & 18.8 & 223.7 & 73.2 & 43.3 & 0.33 & 0.19 & 1650 \\
\hline HVPM03 & 98 & - & - & - & - & - & - & 1900 \\
\hline HVPM04 & 60 & 16.1 & 113.4 & 22.6 & 9.7 & 0.20 & 0.09 & - \\
\hline HVPM05 & 136 & 16.3 & 251 & 61.1 & 37.9 & 0.24 & 0.15 & 1600 \\
\hline HVPM06 & 144 & 12.7 & 213 & 48.9 & 31.6 & 0.23 & 0.15 & 1460 \\
\hline
\end{tabular}

Volatility test with cold cap (IEB4/A-80 and IEB4/A-40)

\begin{tabular}{|c|c|c|c|c|c|c|c|c|}
\hline $\mathrm{CC} 01$ & 62 & 14.3 & 96.2 & 37.3 & 31.2 & 0.39 & 0.32 & 2300 \\
\hline $\mathrm{CC} 02$ & 112 & 9.5 & 82.2 & 31 & 10.7 & 0.38 & 0.13 & 1400 \\
\hline $\mathrm{CC} 03$ & 86 & 14.4 & 144.2 & 69.1 & 24.3 & 0.48 & 0.17 & 2000 \\
\hline $\mathrm{CC} 04$ & 62 & 14.6 & 66.5 & 35.8 & 25.1 & 0.54 & 0.38 & - \\
\hline $\mathrm{CC} 05$ & 80 & 13.6 & 83 & 48.7 & 21.3 & 0.59 & 0.26 & 2100 \\
\hline
\end{tabular}

Reduction tests (IEB4/A-40)

\begin{tabular}{|c|c|c|c|c|c|c|c|c|}
\hline RED01 & 110 & 10.9 & 103.5 & 51.5 & 35.6 & 0.50 & 0.34 & 2000 \\
\hline RED02 & 95 & 11.5 & 106.1 & 22.8 & 11.3 & 0.21 & 0.11 & 1800 \\
\hline
\end{tabular}

Oxidizing tests (IEB4/A-40)

\begin{tabular}{|c|c|c|c|c|c|c|c|c|}
\hline OX01 & 115 & 6.6 & 84.4 & 36 & 3.3 & 0.42 & 0.04 & 1665 \\
\hline OX02 & 125 & 12.8 & 161.3 & 77.2 & 51 & 0.48 & 0.32 & 1850 \\
\hline OX03A & 95 & 13.0 & 36.5 & 57.3 & 43.2 & 1.57 & 1.18 & 1700 \\
\hline OX03B & 120 & 13 & - & 133.1 & 37.7 & - & - & 1900 \\
\hline
\end{tabular}


Table 4.2 Operating conditions and electrode erosion data for the FY-94 experiments.

\begin{tabular}{|c|c|c|c|c|c|c|c|c|}
\hline Test & $\begin{array}{c}\text { Time } \\
(\mathrm{min})\end{array}$ & $\begin{array}{c}\text { Ave } \\
\text { power } \\
(\mathrm{kW})\end{array}$ & $\begin{array}{c}\text { Total } \\
(\mathrm{A}-\mathrm{h})\end{array}$ & $\begin{array}{c}\text { Anode } \\
\text { loss } \\
(\mathrm{g})\end{array}$ & $\begin{array}{c}\text { Cathode } \\
\text { loss } \\
(\mathrm{g})\end{array}$ & $\begin{array}{c}\text { Anode } \\
\text { loss rate } \\
(\mathrm{g} / \mathrm{A}-\mathrm{h})\end{array}$ & $\begin{array}{c}\text { Cathode } \\
\text { loss rate } \\
(\mathrm{g} / \mathrm{A}-\mathrm{h})\end{array}$ & $\begin{array}{c}\text { Max. } \\
\text { slag } \\
\text { temp } \\
\left({ }^{\circ} \mathrm{C}\right)\end{array}$ \\
\hline ARM082394 & 109 & 19.06 & 246.0 & 72.8 & 43.8 & 0.300 & 0.178 & 2005 \\
\hline ARM082694 & 64 & 21.0 & 119.0 & 39.9 & 19.1 & 0.335 & 0.161 & 2113 \\
\hline ARM090694 & 75 & 17.4 & 106.8 & 35.3 & 11.9 & 0.331 & 0.111 & 1962 \\
\hline ARM090894 & 64 & 18.0 & 106.0 & 32.7 & 24.1 & 0.308 & 0.227 & 1677 \\
\hline ARM092094 & 89 & 19.9 & 161 & 40.8 & 17.6 & 0.253 & 0.109 & 1625 \\
\hline ARM092294 & 56 & 20.3 & 99.5 & 40.9 & 37.8 & 0.411 & 0.380 & 1763 \\
\hline
\end{tabular}




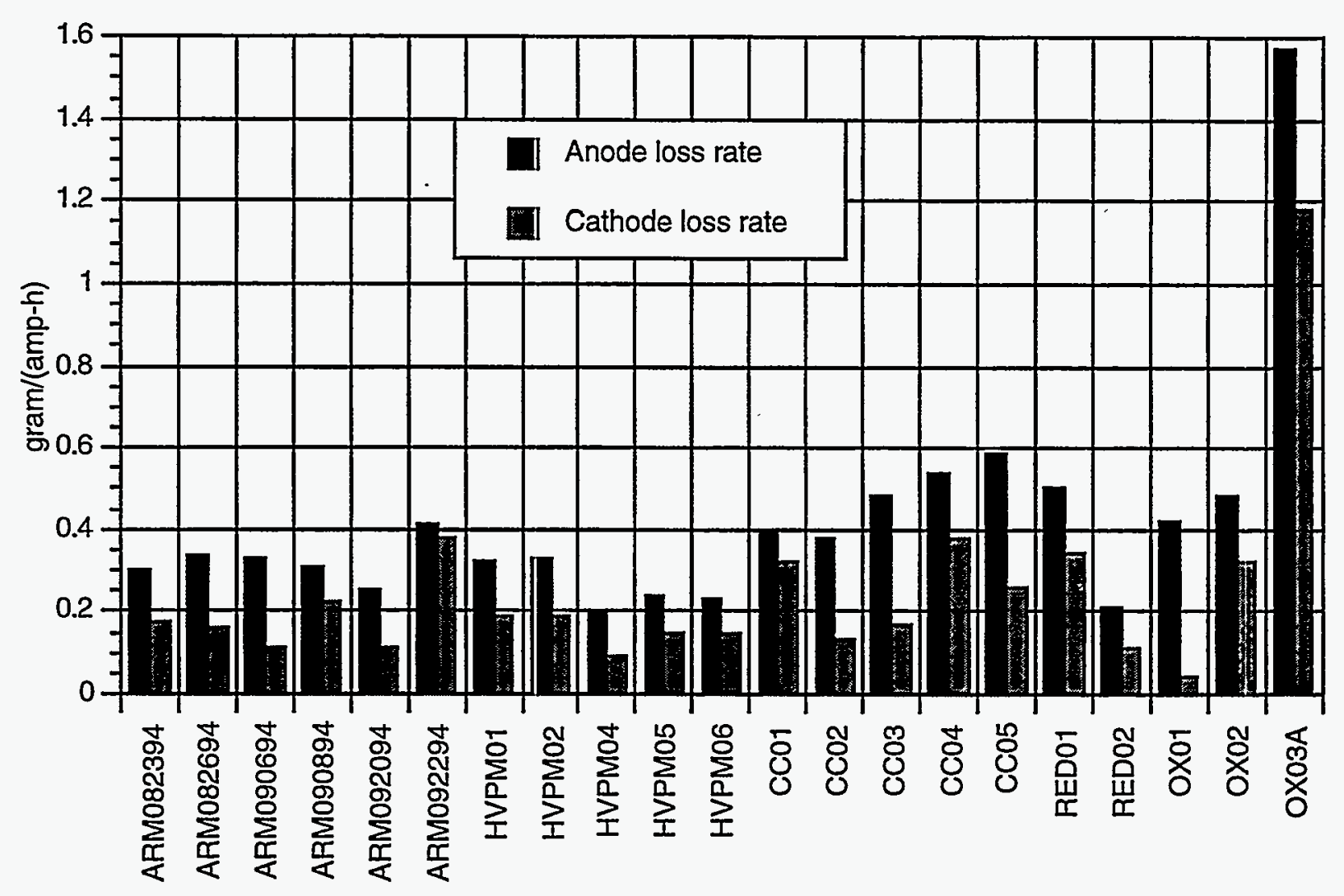

Figure 4.5 Anode and cathode electrode loss rates in grams per amp-h for FY-93 and FY-94 operations. 
reduced the variability in electrode loss rates. Also during FY-94, a Laboratory-Directed Research and Development (LDRD) project examined the electrical signature of the electrodes. The year end LDRD report is located in Appendix A.

Plasma-sprayed Si coatings were also used during the FY-94 tests on the graphite feed tube extension and thermocouple sheaths. A photograph of an uncoated and coated feed tube extension is shown in Figure 4.7. In both cases, the extenders were in the melter for three HVPM runs. Although the uncoated extender was originially shorter than the $\mathrm{SiC}$ coated extender, it is obvious that the coating had a favorable effect. The $\mathrm{SiC}$ coated extender had little weight loss and is very close to original dimensions, where the uncoated extender had $25 \%$ weight loss and is tapered at the end.

\subsection{Temperature Monitoring}

During FY-93 and early FY-94, it was almost impossible to maintain a constant temperature reading on the molten slag. Thermocouple sheath material usually failed within 10 to 20 minutes of exposure to molten slag. Various sheath materials, such as alumina, zirconia, BN and silicon carbide, were used to protect the TCs, but none survived an entire run. A combination graphite, water-cooled probe was developed that allowed the TCs to survive a run. A schematic of the graphite, water-cooled probe is shown in Figure 4.8.

Improved methods of slag temperature monitoring evolved during the course of the FY-94 tests. Type ' $\mathrm{C}$ ' thermocouples were utilized to monitor the slag and soil temperatures for all the runs. Initially, an alumina single sleeve and wire insulator were utilized for the runs, but the alumina was slowly consumed in each case finally resulting in TC failure. The TCs were double sleeved with alumina increasing their life. However, even using the highest grade of alumina did not solve the reaction problem with the molten slag. The double-sleeved TCs were used for ARM082694 run and were left in the melt the whole run. For the ARM090694, run BN sleeves were utilized, which lasted for approximately $70 \%$ of the run with continuous monitoring before the $\mathrm{BN}$ material eroded away. BN was also used as sleeve material for the ARM090894 TCs. During this run the TCs were periodically dipped into melt to ensure operability through the entire run. For the ARM92094 and ARM92294 runs, water cooled thermocouples were utilized. These TCs used a graphite sleeve covering the alumina TC wire insulator and survived the entire run for both cases. The graphite sleeves used for ARM92094 did not extend far enough away from the water-cooled wand and resulted in causing lowered indicated melt temperatures. The slag TCs used during the ARM92294 run were longer and coated with the ZYP SiC coating for added protection. Substantial erosion occurred on these sleeves, but both lasted the entire run. 


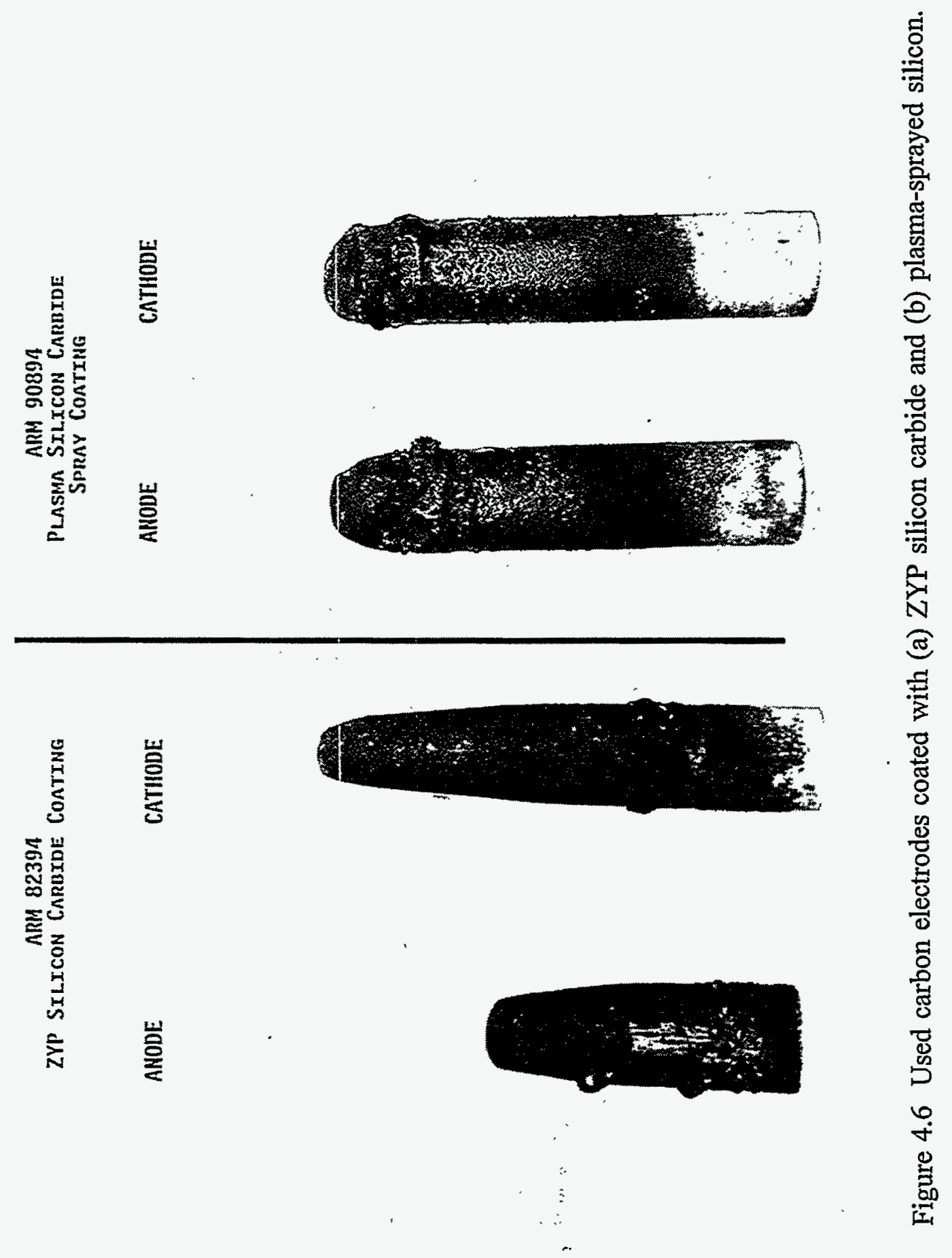




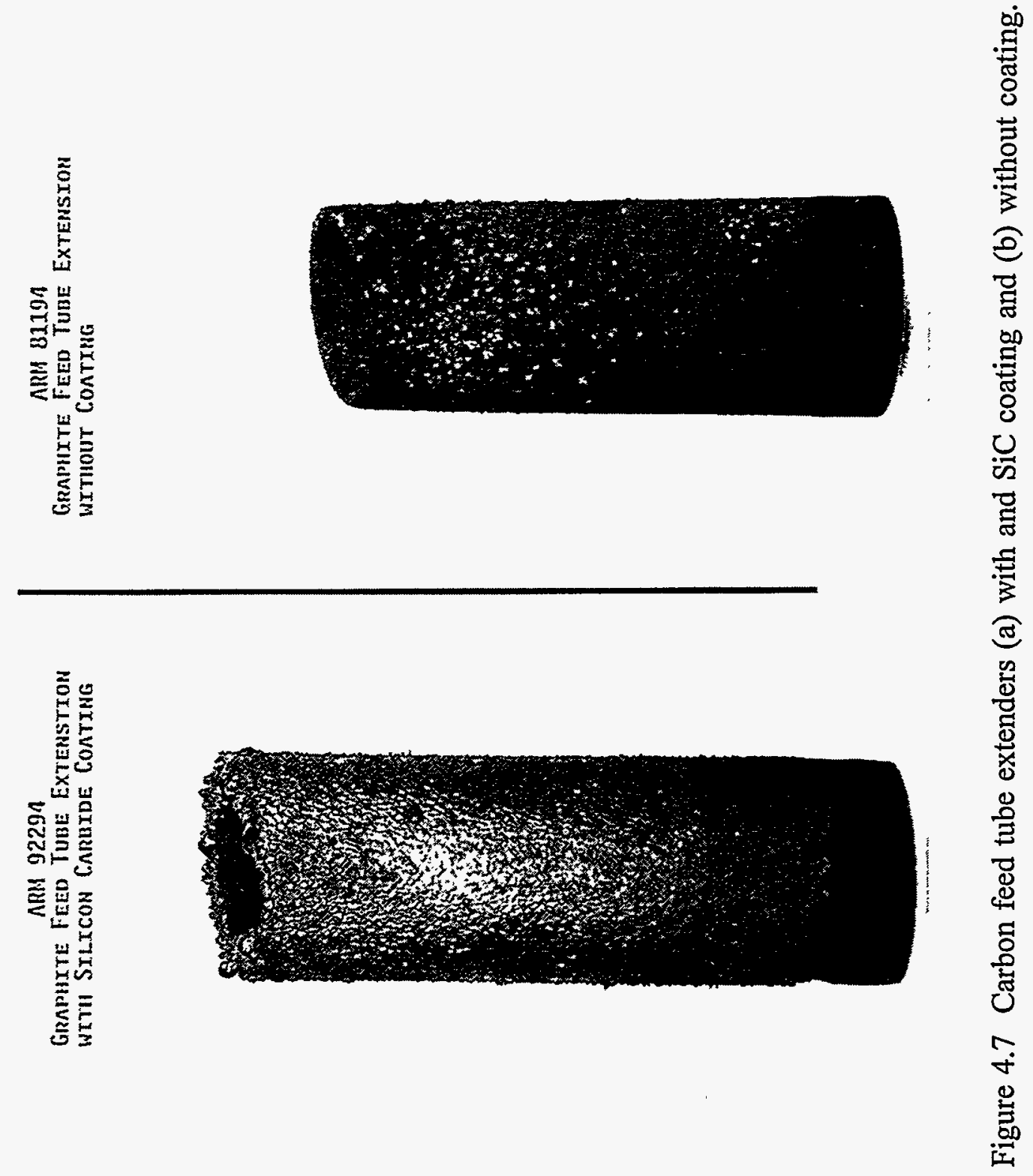




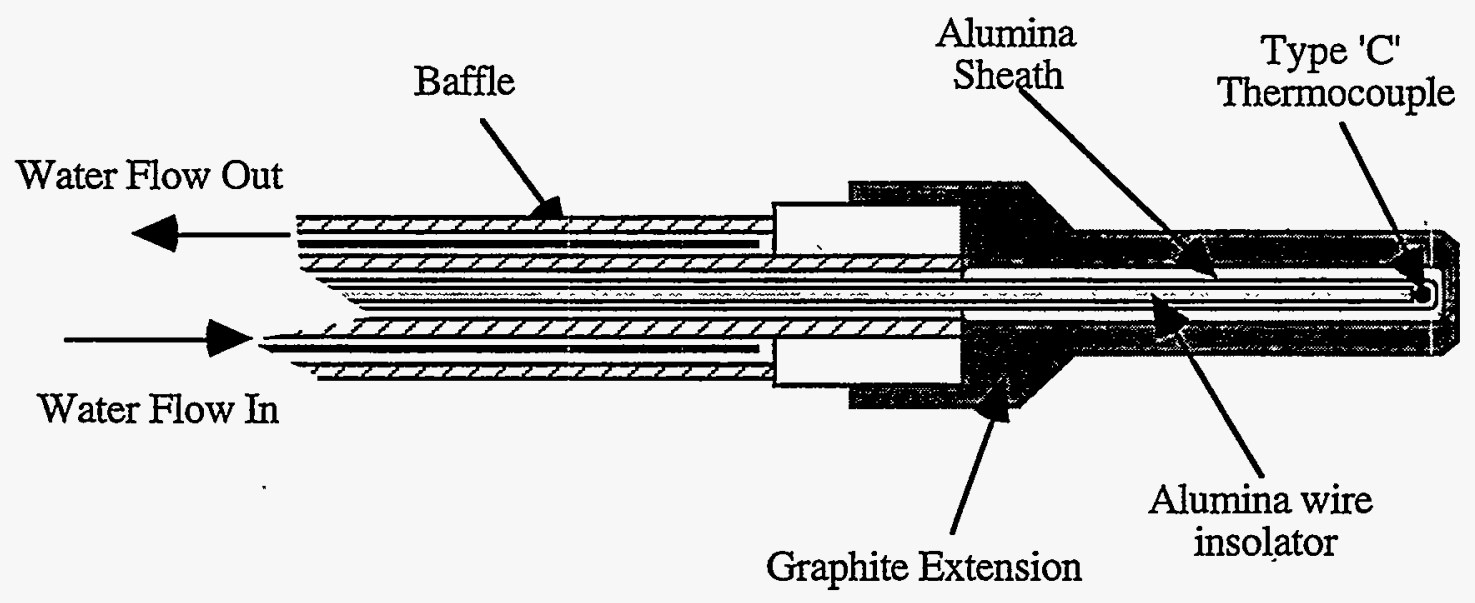

Figure 4.8 Schematic of the water-cooled TC probes used during the FY-94 HVPM tests. 
Two TCs were used for each of the FY-94 tests. One was located near the center of the melt zone, and the other was placed near the edge. In Figure 4.9 the black line is the temperature response near the edge, and grey line is the reponse in the center. The temperature response of the slag at the two locations shows that the operating slag temperature of $1600-1700^{\circ} \mathrm{C}$ was reached after 44 minutes in both locations. At this point in time, the power in and out curves begin to parallel each other (the power out curve is not displayed). 


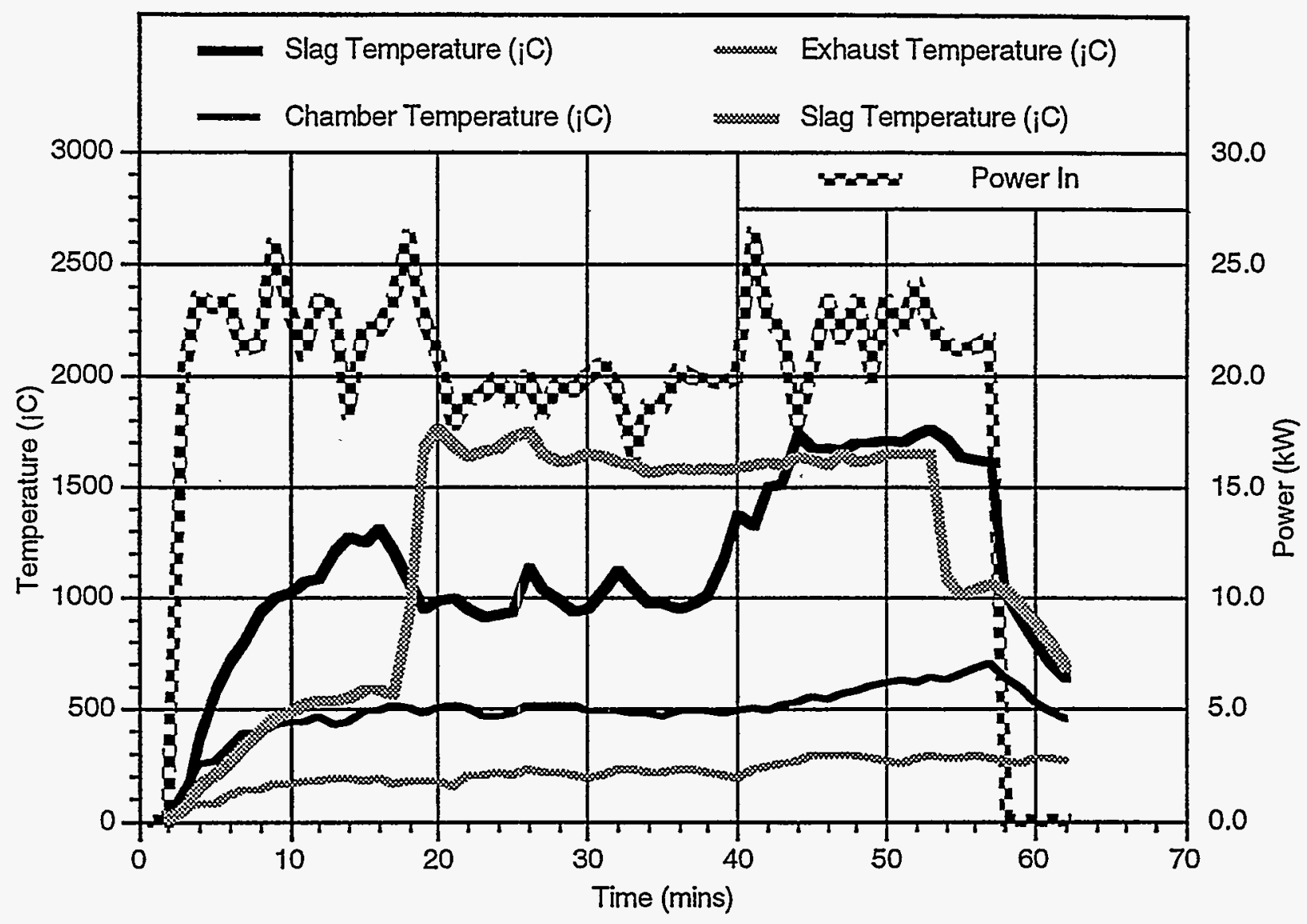

Figure 4.9 Temperature response of the slag and power input versus time for the HVPM run ARM092294. 


\section{VOLATILIZATION AND REDOX TESTING OVERVIEW}

\subsection{Introduction}

This work was performed over a 2-year period in a bench-scale arc melter ${ }^{13,14}$ that was constructed to process simulated TRU waste and soil over a temperature range of 1300 to $1900^{\circ} \mathrm{C}$ and to evaluate the extent of vaporization. Surrogates used in the program that were expected to mimic volatilization characteristics of the TRUs and $\mathrm{U}$ compounds were $\mathrm{CeO}_{2}$, $\mathrm{SmO}_{2}, \mathrm{NdO}_{2}, \mathrm{Eu}_{2} \mathrm{O}_{3}$, and $\mathrm{Gd}_{2} \mathrm{O}_{3}$ for the early FY-93 tests. Later in FY-93 and in all of FY-94, only $\mathrm{CeO}_{2}$ and $\mathrm{SmO}_{2}$ were used as TRU surrogates. In early FY-93, the HVPMs used in the testing were $\mathrm{Cd}, \mathrm{Cr}, \mathrm{Cs}, \mathrm{Pb}$, and $\mathrm{Zn}$ and were all added as metals except for cesium. For later tests, the HVPMs were added as oxides. Due to extremely reactive nature of pure cesium, it was always added as a carbonate $\left(\mathrm{Cs}_{2} \mathrm{CO}_{3}\right)$. These elements cover the range of boiling points of interest and are the major toxic contaminants in TRU wastes that may remain in the solids after incineration. Cs is not toxic, but is a mixed fission product and has high volatility. $\mathrm{Cr}$ is not highly volatile, but is toxic. $\mathrm{Hg}$ was not considered for this series of tests, since it was already assumed that it will completely volatilize and end up in the off-gas collection system. The simulated waste mixtures contained $10 \% \mathrm{TiO}_{2}$ and $5 \% \mathrm{ZrO}_{2}$ by total weight and $1 \%$ each of the HVPMs and TRU surrogates.

As a convenient reference, the melting and boiling points of the elements above plus their relevant oxide forms are listed in Table 5.1 as contained in the CRC Handbook of Chemistry and Physics. ${ }^{15}$ Both metals and oxides are listed since conditions within the melter (oxidizing vs. reducing) may transform the metals into oxide forms or reduce metal oxides to metals.

\subsection{HVPM Tests (FY-93)}

This series of tests was designed to measure the extent of volatilization of several HVPMs and radionuclide surrogates to be processed in an arc melter environment. In these experiments, particulates in the exhaust gases were collected using an exhaust gas analyzer. The off-gas samples were intended to be obtained at melt temperatures $1900,1600,1450$, and $1300^{\circ} \mathrm{C}$. Control of the arc melter was not that precise, but the melt temperatures for the various experiments spanned the desired range. The exhaust gas particulates and slag were analyzed for composition. Table 5.2 below summarizes analytical testing for both the HVPM and cold cap experiments. 
Table 5.1 Melting and boiling points of HVPMs and surrogates plus oxides.

\begin{tabular}{|c|c|c|c|c|c|}
\hline Metal & $\begin{array}{l}\text { Melting } \\
\text { point } \\
\left({ }^{\circ} \mathrm{C}\right)\end{array}$ & $\begin{array}{l}\text { Boiling } \\
\text { point } \\
\left({ }^{\circ} \mathrm{C}\right)\end{array}$ & Oxides & $\begin{array}{c}\text { Melting } \\
\text { point } \\
\left({ }^{\circ} \mathrm{C}\right)\end{array}$ & $\begin{array}{c}\text { Boiling } \\
\text { point } \\
\left({ }^{\circ} \mathrm{C}\right)\end{array}$ \\
\hline \multirow[t]{2}{*}{$\mathrm{Cd}$} & 320.9 & 765 & $\mathrm{CdO}$ amph & $>1500$ & d $900-1000$ \\
\hline & & & $\mathrm{CdO}$ cub & $>1500$ & subl 1559 \\
\hline \multirow[t]{3}{*}{$\mathrm{Cr}$} & $1857 \pm 20$ & 2672 & $\mathrm{CrO}$ & & \\
\hline & & & $\mathrm{CrO}_{2}$ & 300 & \\
\hline & & & $\mathrm{Cr}_{2} \mathrm{O}_{3}$ & $2266 \pm 25$ & 4000 \\
\hline \multirow[t]{5}{*}{$\mathrm{Pb}$} & 327.5 & 1740 & $\mathrm{PbO}$ & 886 & \\
\hline & & & $\mathrm{PbO}_{2}$ & 290 & \\
\hline & & & $\mathrm{Pb}_{2} \mathrm{O}$ & $\mathrm{d}$ & \\
\hline & & & $\mathrm{Pb}_{2} \mathrm{O}_{3}$ & 370 & \\
\hline & & & $\mathrm{Pb}_{3} \mathrm{O}_{4}$ & 500 & \\
\hline $\mathrm{Zn}$ & 419.6 & 907 & $\mathrm{ZnO}$ & 1975 & \\
\hline \multirow[t]{4}{*}{ Cs } & $28.4 \pm 0.01$ & 669.3 & $\mathrm{Cs}_{2} \mathrm{O}$ & d 400; & \\
\hline & & & $\mathrm{Cs}_{2} \mathrm{O}_{2}$ & 400 & 650 \\
\hline & & & $\mathrm{Cs}_{2} \mathrm{O}_{3}$ & 400 & \\
\hline & & & $\mathrm{Cs}_{2} \mathrm{CO}_{3}$ & d 610 & \\
\hline \multirow[t]{2}{*}{$\mathrm{Ce}$} & 798 & 3443 & $\mathrm{CeO}_{2}$ & ca 2600 & \\
\hline & & & $\mathrm{Ce}_{2} \mathrm{O}_{3}$ & $\begin{array}{c}1692 \\
\text { ign } 200\end{array}$ & \\
\hline $\mathrm{Sm}$ & 1074 & 1793 & $\mathrm{Sm}_{2} \mathrm{O}_{3}$ & & \\
\hline $\mathrm{Nd}$ & 1021 & 3074 & $\mathrm{Nd}_{2} \mathrm{O}_{3}$ & $\sim 1900$ & \\
\hline $\mathrm{Eu}$ & 822 & 1527 & $\mathrm{Eu}_{2} \mathrm{O}_{3}$ & & \\
\hline $\mathrm{Gd}$ & 1313 & 3273 & $\mathrm{Gd}_{2} \mathrm{O}_{3}$ & $2330 \pm 20$ & \\
\hline
\end{tabular}

amph - amorphous, ca - calculated, cub - cubic, d - decomposes, ign - ignites, subl - sublimates 
Table 5.2 HVPM analyses for FY-93 HVPM and cold cap experiments.

\begin{tabular}{|l|l|l|}
\hline \multicolumn{1}{|c|}{ Sample type } & \multicolumn{1}{|c|}{ Method } & \multicolumn{1}{|c|}{ Elements } \\
\hline slag (TCLP only) & $\begin{array}{l}\text { SW-846 1311, 3010, USEPA 200.8, and } \\
\text { any furnace AA methods necessary to } \\
\text { meet TCLP requirements provided in } \\
\text { ERD-SOW-107 }\end{array}$ & $\mathrm{Cd}, \mathrm{Cr}, \mathrm{Pb}$ \\
\hline slag & USEPA 200.8 & $\begin{array}{l}\mathrm{Al}, \mathrm{Ca}, \mathrm{Cd}, \mathrm{Cr}, \mathrm{Ce}, \mathrm{Cs}, \\
\mathrm{Fe}, \mathrm{Gd}, \mathrm{K}, \mathrm{Mg}, \mathrm{Na}, \mathrm{Nd}, \\
\mathrm{Pb}, \mathrm{Si}, \mathrm{Sm}, \mathrm{Ti}, \mathrm{Zn}, \mathrm{Zr}\end{array}$ \\
\hline soil & USEPA 200.8 & $\begin{array}{l}\mathrm{Al}, \mathrm{Ca}, \mathrm{Cd}, \mathrm{Cr}, \mathrm{Fe}, \mathrm{K}, \\
\mathrm{Mg}, \mathrm{Na}, \mathrm{Pb}, \mathrm{Si}, \mathrm{Ti}, \mathrm{Zn}, \mathrm{Zr}\end{array}$ \\
\hline glass fiber filters & USEPA 200.8 & $\begin{array}{l}\mathrm{Cd}, \mathrm{Ce}, \mathrm{Cs}, \mathrm{Cr}, \mathrm{Gd} \mathrm{Nd}, \\
\mathrm{Pb}, \mathrm{Sm}, \mathrm{Zn}\end{array}$ \\
\hline impinger liquid & USEPA 200.8 & $\begin{array}{l}\mathrm{Cd}, \mathrm{Ce}, \mathrm{Cs}, \mathrm{Cr}, \mathrm{Gd} \mathrm{Nd}, \\
\mathrm{Pb}, \mathrm{Sm}, \mathrm{Zn}\end{array}$ \\
& & \\
\hline
\end{tabular}

\subsection{Cold Cap Tests (FY-93)}

A cold cap of IEB4/A40 with HVPM and TRU surrogates was used during these tests to study its effect on volatilization of the HVPM and TRU surrogates. The tests focused on global (total mass as opposed to elemental mass) volatilization from the melt having a cold cap of feed material over the surface of the melt. One technique sometimes employed to minimize volatization from a molten surface is to over load that surface with feed material, effectively placing a cold cap on the melt surface. Materials will condense on the cold cap and be returned to the melt as the cold cap is consumed from beneath. Raw material is added from above to maintain a desired thickness of cap material. In a batch-type operation, the cold cap will be consumed prior to securing the operation. 


\subsection{Redox Tests (FY-93)}

Oxidizing and reducing conditions were varied during melting in a preliminary effort to determine the effect, if any, of redox on retention and distribution of the HVPMs, Cs, and TRU surrogates in the melt. Four experiments were run that may individually be described as highly reducing, slightly reducing, slightly oxidizing, and highly oxidizing. All redox melts were made without a cold cap, and the exhaust gas analyzer was not used. Compositional analysis and examination of crystalline and amorphous phases of the slags were done using SEM/EDXS. Compositions were also determined using inductively coupled plasma/ atomic emission spectroscopy (ICP/AES) and flame atomic absorbtion (FLAA) Spectroscopy. An independent lab, determined the $\mathrm{Fe}^{+2} / \mathrm{Fe}^{+3}$ ratios.

\subsection{Volatilization Tests (FY-94)}

The purpose of the FY-94 HVPM tests was to determine methods to retain surrogates and HVPMs in the final waste form (IEB4/A-40). In order to analyze these methods, quantitative mass balances were needed during melter operations. An accurate mass balance was obtained by a procedure developed to measure all input and output materials. Prior to FY-94 testing, the arc melter system was modified to improve its operabililty and performance with the goal of total material recovery, which would allow accurate mass balances to be made.

$\mathrm{XRF}$ and EDXS analyses were done to determine elemental compositions of both the filter particulates and slags. An independent ICP analysis was also conducted by a commercial analytical lab to determine metals basis compositions for particulates and slags. 


\section{HVPM RETENTION AND EXHAUST GAS ANALYSIS (FY-93)}

\subsection{Introduction}

These experiments began with a $6.0 \mathrm{~kg}$ charge of IEB4/A-80 mix in the melter. This amount of material would take 45 minutes to 1 hour to melt depending upon the input power and whether a cast ceramic insert or crucible was installed in the melter. A crucible insert provides some insulation from the water-cooled stainless steel wall and thus reduces the overall amount of energy needed to melt a charge of material. Once this initial charge had melted, the A-40 mix with HVPMs and TRUs was added via the auger feeder system. Slag and off-gas samples were collected during the feeding operations. Problems with the electrodes and exhaust plug ups limited the length of most of these runs. Table 6.1 outlines some of the basic parameters of the HVPM and cold cap experiments.

Additions of alkali (IEB4/A-40 $+\mathrm{KOH}$ and $\mathrm{NaOH}$ ) and adjusting power input were to be used to control melt viscosity and temperature. Melt viscosity varies mainly as a function of temperature: the higher the temperature the lower the viscosity. Only in experiment HVPM05 was alkali added to decrease viscosity. For this series of tests, the melt temperature was monitored using a type $\mathrm{C}$ thermocouple probe sheathed with a high-temperature alumina tube. The probe would be lowered into the melt and held there until the temperature reading stabilized, whereupon it would be withdrawn to prevent damage.

\subsection{Data Collection}

The primary goal of determining the extent and nature of volatilization within the arc melter system requires that volatile materials be tracked through the system as it is operating. To achieve this, both the melt and particulates entrained in the exhaust gases were sampled and analyzed to determine the concentrations of HVPMs and TRU surrogates they contained.

\subsubsection{Slag Sampling}

Slag samples were extracted directly from the melt just before and just after each exhaust gas sample collection. Slag samples were collected during FY-93 by using a quartz tube with an aspiration device, shown schematically in Figure 6.1. The aspiration device concists of three components: a venturi vacuum pump, a vacuum control valve, and a vacuum cut-off valve. The quartz tube is used to collect the sample. As 90 psi air is forced 
Table 6.1 FY-93 HVPM and cold cap test series.

\begin{tabular}{|c|c|c|c|c|c|c|}
\hline $\begin{array}{l}\text { Test } \\
\text { name }\end{array}$ & Date & Starting material & Additions & $\begin{array}{l}\text { Cruc. } \\
\text { insert }\end{array}$ & $\begin{array}{l}\text { Run } \\
\text { time }\end{array}$ & $\begin{array}{l}\text { Shutdown } \\
\text { condition }\end{array}$ \\
\hline HVPM01 & $6 / 18$ & $\begin{array}{l}6.0 \mathrm{~kg} \text { IEB4/A-80 } \\
\text { + HVPM's } \\
\text { + Surrogates }\end{array}$ & $\begin{array}{l}1.0 \mathrm{~kg} \mathrm{IEB} 4 / \mathrm{A}-40 \\
+ \text { + HVPM's } \\
\text { + Surrogates }\end{array}$ & no & $\begin{array}{l}2 \mathrm{hr} \\
49 \mathrm{~m}\end{array}$ & $\begin{array}{l}\text { Normal } \\
\text { (some } \\
\text { damage to } \\
\text { anode) }\end{array}$ \\
\hline HVPM02 & $6 / 23$ & $6.0 \mathrm{~kg}$ IEB $4 / \mathrm{A}-80$ & $\begin{array}{l}1.0 \mathrm{~kg} \mathrm{IEB} 4 / \mathrm{A}-40 \\
+\mathrm{H}+\mathrm{S}\end{array}$ & no & $\begin{array}{l}2 \mathrm{hr} \\
5 \mathrm{~m}\end{array}$ & $\begin{array}{l}\text { Exhaust } \\
\text { plug up }\end{array}$ \\
\hline HVPM03 & $6 / 24$ & $6.0 \mathrm{~kg}$ IEB4/A-80 & $\begin{array}{l}1.0 \mathrm{~kg} \mathrm{IEB} 4 / \mathrm{A}-40 \\
+\mathrm{H}+\mathrm{S}\end{array}$ & no & $\begin{array}{l}1 \mathrm{hr} \\
38 \mathrm{~m}\end{array}$ & $\begin{array}{l}\text { Exhaust } \\
\text { plug up }\end{array}$ \\
\hline HVPM04 & $6 / 25$ & $\begin{array}{l}\text { HVPM03 remelt } \\
+0.7 \mathrm{~kg} \text { alkali }\end{array}$ & (none) & yes & $1 \mathrm{hr}$ & $\begin{array}{l}\text { Exhaust } \\
\text { plug up }\end{array}$ \\
\hline HVPM05 & $7 / 01$ & $\begin{array}{l}\text { HVPM04 remelt } \\
+0.5 \mathrm{~kg} \\
\text { IEB4/A-40 }\end{array}$ & $\begin{array}{l}2.0 \mathrm{~kg} \mathrm{IEB} 4 / \mathrm{A}-40 \\
+\mathrm{H}+\mathrm{S} \\
+.87 \mathrm{~kg} \text { alkali }\end{array}$ & yes & $\begin{array}{l}2 \mathrm{hr} \\
16 \mathrm{~m}\end{array}$ & $\begin{array}{l}\text { Exhaust } \\
\text { plug up }\end{array}$ \\
\hline HVPM06 & $7 / 02$ & $\begin{array}{l}\text { HVPM05 remelt } \\
+0.5 \mathrm{~kg} \\
\text { IEB4/A-40 }\end{array}$ & $\begin{array}{l}4.0 \mathrm{~kg} \mathrm{IEB} 4 / \mathrm{A}-40 \\
+\mathrm{H}+\mathrm{S}\end{array}$ & yes & $\begin{array}{l}2 \mathrm{hr} \\
24 \mathrm{~m}\end{array}$ & Normal \\
\hline $\mathrm{CC} 01$ & $7 / 09$ & $\begin{array}{l}6 \mathrm{~kg} \mathrm{IEB} 4 / \mathrm{A}-80 \\
+0.5 \mathrm{~kg} \\
\cdot \text { IEB } 4 / \mathrm{A} 40\end{array}$ & $\begin{array}{l}6.0 \mathrm{~kg} \mathrm{IEB} 4 / \mathrm{A}-40 \\
+\mathrm{H}+\mathrm{S}\end{array}$ & yes & $\begin{array}{l}1 \mathrm{hr} \\
02 \mathrm{~m}\end{array}$ & Normal \\
\hline $\mathrm{CCO} 2$ & $7 / 13$ & $6 \mathrm{~kg}-\mathrm{IEB} 4 / \mathrm{A}-80$ & $\begin{array}{l}6.0 \mathrm{~kg} \mathrm{IEB} 4 / \mathrm{A}-40 \\
+\mathrm{H}+\mathrm{S}\end{array}$ & yes & $\begin{array}{l}1 \mathrm{hr} \\
52 \mathrm{~m}\end{array}$ & Normal \\
\hline $\mathrm{CCO} 3$ & $7 / 14$ & $6 \mathrm{~kg}-\mathrm{IEB} 4 / \mathrm{A}-80$ & $\begin{array}{l}6.0 \mathrm{~kg} \mathrm{IEB} 4 / \mathrm{A}-40 \\
+\mathrm{H}+\mathrm{S}\end{array}$ & yes & $\begin{array}{l}1 \mathrm{hr} \\
26 \mathrm{~m}\end{array}$ & $\begin{array}{l}\text { Auger feed } \\
\text { tube plug }\end{array}$ \\
\hline $\mathrm{CC04}$ & $7 / 15$ & $6 \mathrm{~kg}-\mathrm{IEB} 4 / \mathrm{A}-80$ & (none) & yes & $\begin{array}{l}1 \mathrm{hr} \\
02 \mathrm{~m}\end{array}$ & Water leak \\
\hline $\mathrm{CCO5}$ & $7 / 16$ & $6 \mathrm{~kg}-\mathrm{IEB} 4 / \mathrm{A}-80$ & $\begin{array}{l}6.0 \mathrm{~kg} \mathrm{IEB} 4 / \mathrm{A}-40 \\
+\mathrm{H}+\mathrm{S}\end{array}$ & yes & $\begin{array}{l}1 \mathrm{hr} \\
20 \mathrm{~m}\end{array}$ & $\begin{array}{l}\text { Normal } \\
\text { (damage to } \\
\text { anode } \\
\text { occurred) }\end{array}$ \\
\hline
\end{tabular}




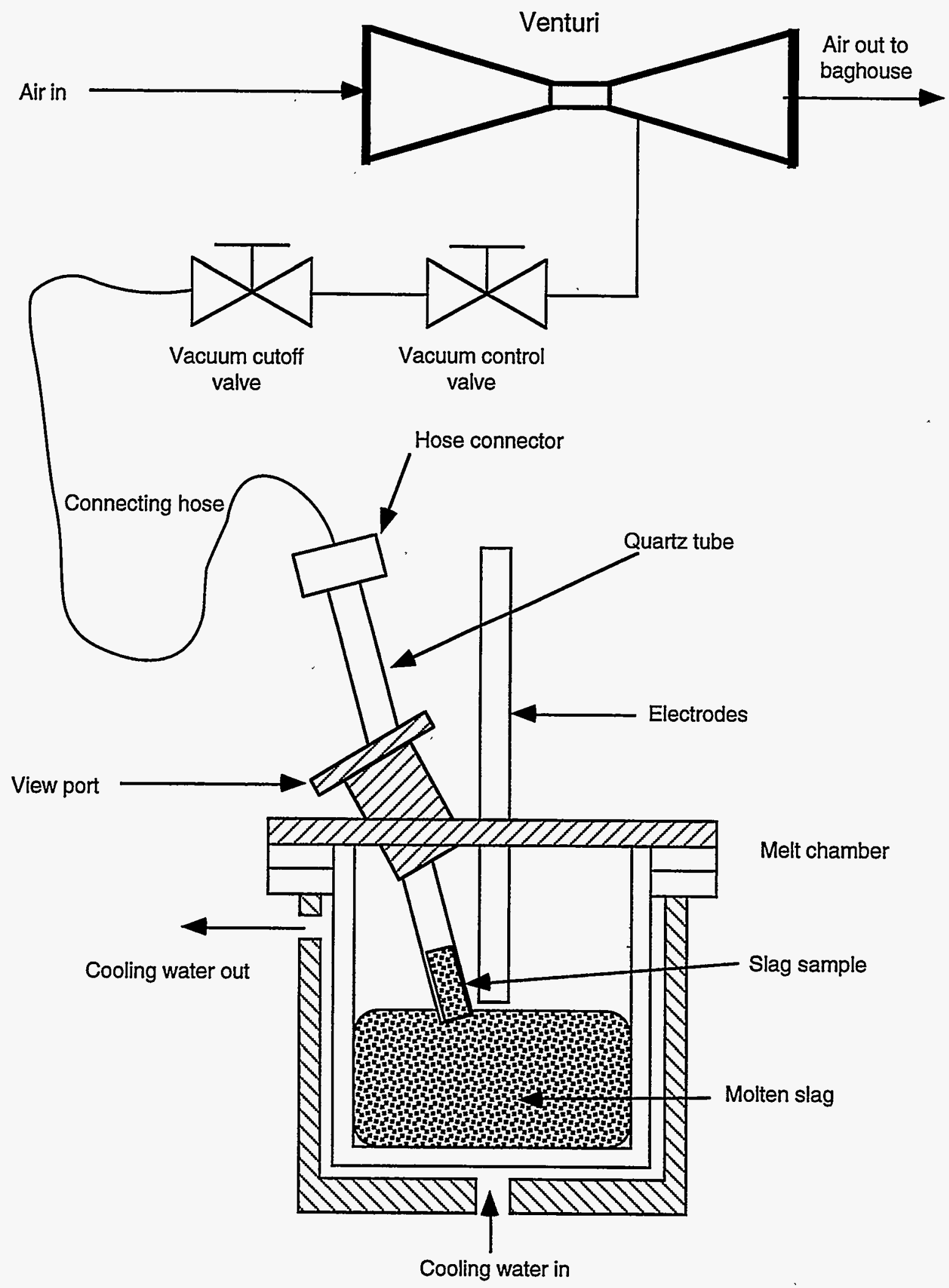

Figure 6.1 Sketch of the slag sampling system used during the FY-93 HVPM studies. 
through it, the venturi vacuum pump creates a negative pressure in the quartz tube causing slag to be sucked up inside it. The transparent quartz tube allows the operator to see the amount of slag collected. The vacuum in the quartz tube is controlled by adjusting the control valve, and the vacuum cut-off valve provides a means to put a vacuum lock on the sample, holding the molten material inside the quartz tube. To prevent slag samples in large tubes from draining out of the quartz tube back into the melt, the arc melter was shut off to allow the sample to become more viscous prior to extraction.

\subsubsection{Exhaust Gas Sampling}

The off-gas sampling train used during the FY-93 experiments was an EPA "Modified Method 5" system and is illustrated in Figure 6.2. It consists of a series of bubblers containing nitric acid solutions for the digestion of the metals content of the off-gas stream. The entire off-gas volume flows through the solutions, depositing soluble species, and proceeds to the scrubber. The bubblers collect residues for a period of time, determined by the expected species concentration present in the off-gas, volume flow rate, and detection limits of the analytical techniques employed. At the end of the sampling period, the train is isolated from the melter outlet, and the solutions are recovered for off-line analysis. Operating procedures for the off-gas sampling train are located in the Appendix B.

As the procedure describes, two leak checks before and one after train operation were performed. The first leak check took place off-line and confirmed that all impinger and filter connections met EPA specifications for seal integrity. Leaks were detected at this stage during some tests. In those cases, the leak location was determined by observation of bubbling in the impinger fluids. Leaks were reduced to an acceptable level by repositioning components, careful application of appropriate sealant to contacting surfaces, or replacement of components. When this check was successfully concluded, the second pretest check took place with the train connected to the melter assembly through the swagelok fitting, with the valve to the train closed. That check confirmed the integrity of the fitting. When a leak was detected at this stage, it was resolved by adjusting the fitting, or by applying sealant to the outer fitting surface. A similar procedure was carried out at the conclusion of the sampling procedure. One post-test leak check fell short of the EPA requirements by a small amount during one sample collection run. In that case, the leak flow rate at the lowest level of vacuum attained during sample collection was recorded. That flow rate was used in a correction procedure applied to the data in the analysis phase.

Off-gas sample collection began when the melter sampling valve was opened and the baghouse valve closed. The gas flow rate through the sample train was controlled via the METHOD-5 BOX bypass valve, with the coarse valve fully open. Significant flow rate 


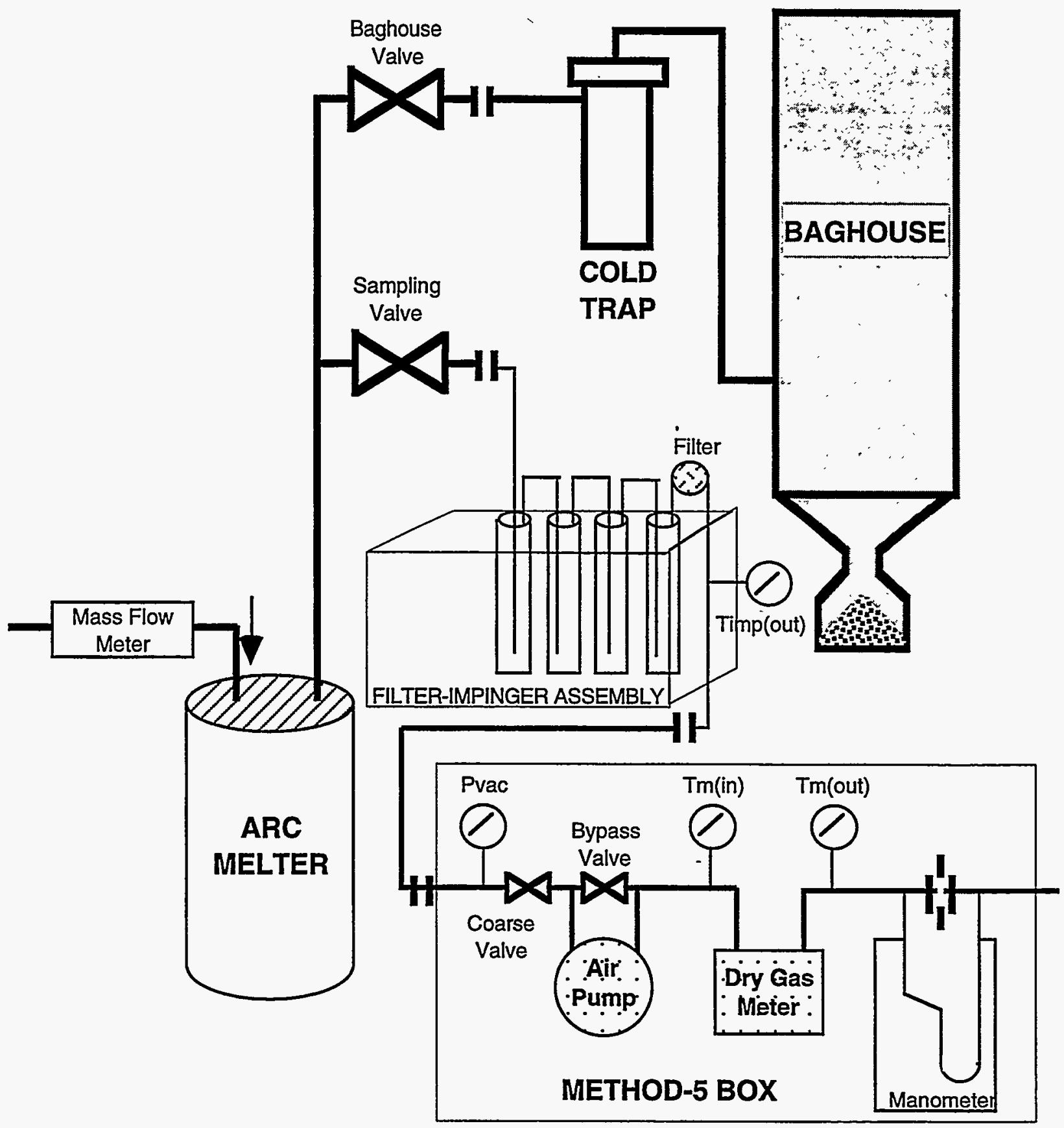

Figure 6.2 Schematic of the exhaust gas sampling train circa FY-93. 
fluctuation occurred during soil addition to the melter. The bypass valve was used during these times to attempt to maintain the flow rate as closely as possible to the undisturbed flow rate.

Exhaust sample collection times varied from 9 to 30 minutes. These sampling time durations are expected to be more than adequate for collection of samples exceeding analytical detection limits, particularly since the loading in exhaust gases was very high. Some general information about the tests is contained in Table 6.2 and summarized in Table 6.3. After just a few minutes of operation, off-gas condensates were readily visible on the sampling train assembly filter and glass fittings prior to the impingers. In fact, during some tests in which the particulate loading was heavy, the sampling train filter capacity was nearly exceeded. This resulted in a notable increase in pressure drop across the filter assembly as condensible matter built up on the filter. In some cases, the filter ruptured. Consequences of this were increasing difficulty in maintaining the desired flow rate through the sample train with the available pump capacity, and also loading of the impinger fluids and fittings with excessive particulates and condensible matter. To remedy this and to ensure adequate sampling train capacity to extract all particulates and condensible matter from the off-gas stream, the following modifications were made to the sample train assembly, beginning with run HVPM06:

1. An additional nitric acid impinger was added to the train, bringing the total number of active impingers for solids digestion to three.

2. The volume of nitric acid in each of the first two impingers was doubled from 100 to $200 \mathrm{ml}$. The volume of the third impinger remained at $100 \mathrm{ml}$, increasing the total nitric acid volume in the train to $500 \mathrm{ml}$ compared to the original $300 \mathrm{ml}$.

3. To help deal with the high particulate loadings, two filters were used in the filter assembly rather than just one. This increased the pressure drop across the filter assembly, but added strength to the filter, preventing the rupturing that had occurred previously during intervals with heavy particulate loadings. 
Table 6.2 Metals sample information for the FY-93 HVPM and cold cap test series.

\begin{tabular}{|c|c|}
\hline $\begin{array}{c}\text { Test } \\
\text { name }\end{array}$ & Experimental conditions and comments \\
\hline HVPM01 & $\begin{array}{l}\text { Start with } 6.0 \mathrm{~kg} \text { of HVPM and surrogates in A-80 mix. Melt temperature of } 1220^{\circ} \mathrm{C} \text { prior to } \\
\text { sampling } 16.2 \mathrm{~kW} \text {. Feed } 1.0 \mathrm{~kg} \mathrm{~A}-40+\mathrm{H}+\mathrm{S} \text { mix during first } 15 \text { minutes of sample. }\end{array}$ \\
\hline$"$ & Melt temperature of $1350^{\circ} \mathrm{C}$ prior to sampling, $1460^{\circ} \mathrm{C}$ just after, $24 \mathrm{~kW}$. No materials fed. \\
\hline HVPM02 & $\begin{array}{l}\text { Start with } 6.0 \mathrm{~kg} \text { of IEB } 4 / \mathrm{A}-80 \text { mix. Melt temperature } 1650^{\circ} \mathrm{C} \text { prior to sampling, } 21 \mathrm{~kW} \text {. Fed } \\
1.0 \mathrm{~kg} \mathrm{~A}-40 \text { with HVPM and surrogates for first } 15 \text { minutes. }\end{array}$ \\
\hline HVPM03 & $\begin{array}{l}\text { Start with } 6.0 \mathrm{~kg} \text { of IEB } 4 / \mathrm{A}-80 \mathrm{mix} \text {. Melt temperature } 1900^{\circ} \mathrm{C} \text { prior to sampling, } 1800-1900^{\circ} \mathrm{C} \\
\text { after. Fed } 1.0 \mathrm{~kg} \text { of IEB4/A-40. Train filter clogged during sampling. }\end{array}$ \\
\hline HVPM04 & $\begin{array}{l}\text { Restart of HVPM03 with } 0.7 \mathrm{~kg} \text { of IEB } 4 / \mathrm{A}-40+\text { alkali, extremely thick green smoke, exhaust } \\
\text { system plugged } 1 \text { hour after starting. }\end{array}$ \\
\hline HVPM05 & $\begin{array}{l}\text { Remelt of HVPM04 with } 0.5 \mathrm{~kg} \text { of IEB } 4 / \mathrm{A}-40 \text {. Melt temperature before and after sample was } \\
1600^{\circ} \mathrm{C}, 18 \mathrm{~kW} \text {. Fed in } 1.0 \mathrm{~kg} \text { of IEB } 4 / \mathrm{A}-40+\mathrm{H}+\mathrm{S} \text { for first } 15 \text { minutes. Fed in } 0.87 \mathrm{~kg} \text { of } \\
\text { alkali mix. }\end{array}$ \\
\hline$"$ & $\begin{array}{l}\text { Melt temperature at } 1500^{\circ} \mathrm{C} \text { before sampling. Fed in } 1.0 \mathrm{~kg} \text { of IEB } 4 / \mathrm{A}-40+\mathrm{H}+\mathrm{S} \text { during } \\
\text { sampling time, sampling was cut short due to a clog in the exhaust pipe. }\end{array}$ \\
\hline HVPM06 & $\begin{array}{l}\text { Restart previous melt with } 0.5 \mathrm{~kg} \text { of IEB } 4 / \mathrm{A}-40 \text {. Added } 1.0 \mathrm{~kg} \text { of IEB } 4 / \mathrm{A}-40+\mathrm{H}+\mathrm{S} \text {. The } \\
\text { filter in the metals sample train clogged up after only } 6 \text { minutes. }\end{array}$ \\
\hline " & $\begin{array}{l}\text { Melt temperature } 1420^{\circ} \mathrm{C} \text { before sampling and } 1460^{\circ} \mathrm{C} \text { after, } 4.9 \mathrm{~kW} \text { (one power supply). Fed } \\
\text { IEB } 4 \mathrm{~A}-40+\mathrm{H}+\mathrm{S} \text { during sampling interval. Fed } 2.0 \mathrm{~kg} \text { IEB } 4 / \mathrm{A}-40 \text { after sampling. }\end{array}$ \\
\hline $\mathrm{CC} 01$ & $\begin{array}{l}\text { Start with } 6.0 \mathrm{~kg} \text { of IEB } 4 / \mathrm{A}-80 \text {. Restart with } 0.5 \mathrm{~kg} \text { IEB } 4 / \mathrm{A}-40 \text {. Measurements }\left(>2300^{\circ} \mathrm{C}\right) \\
\text { before and during sampling, } 18.8 \mathrm{~kW} \text {, cold-cap established } 40 \text { seconds after starting sample, } \\
\text { momentarily lost cold-cap after } 10 \text { minutes. Fed total of } 7.068 \mathrm{~kg} \text { of IEB } 4 / \mathrm{A}-40+\mathrm{H}+\mathrm{S} \text {. }\end{array}$ \\
\hline $\mathrm{CC} 02$ & $\begin{array}{l}\text { Start with } 6.0 \mathrm{~kg} \text { of IEB4/A-80. Melt temperature during sampling, } 1400,1350 \& 1250^{\circ} \mathrm{C} \text {, } \\
3.2 \mathrm{~kW} \text {, cold-cap established } 40 \mathrm{~s} \text { after starting sample. Fed } 3.196 \mathrm{~kg} \text { of IEB } 4 / \mathrm{A}-40+\mathrm{H}+\mathrm{S}\end{array}$ \\
\hline $\mathrm{CCO} 3$ & $\begin{array}{l}\text { Start with } 6.0 \mathrm{~kg} \text { of IEB4/A-80. Melt temperature at } 1870-2000^{\circ} \mathrm{C} \text { at } 12.8 \mathrm{~kW} \text { cold cap } \\
\text { established just before sampling, the feeder plugged up forcing termination of sampling when } \\
\text { the cold cap was lost, the melt temperature after sampling was } 1750^{\circ} \mathrm{C} \text {. Fed } 6.684 \mathrm{~kg} \text { of } \\
\text { IEB4/A- } 40+\mathrm{H}+\mathrm{S} \text {. }\end{array}$ \\
\hline $\mathrm{CCO4}$ & Start with $6.0 \mathrm{~kg}$ of IEB4/A-80. Pinhole water leak prevented taking a sample. \\
\hline $\mathrm{CCO5}$ & $\begin{array}{l}\text { Start with } 6.0 \mathrm{~kg} \text { of IEB } 4 / \mathrm{A}-80 \text {. Initial melt temperature of } 2000-2100^{\circ} \mathrm{C} \text { at } 13.8 \mathrm{~kW} \text {, cold-cap } \\
\text { took over a minute to establish at highest feed rate setting, after } 15 \text { minutes melt temperature } \\
\text { was } 2000^{\circ} \mathrm{C} \text { at } 16.0 \mathrm{~kW} \text {. Fed } 4.031 \mathrm{~kg} \text { of IEB } 4 / \mathrm{A}-40+\mathrm{H}+\mathrm{S} \text {. }\end{array}$ \\
\hline
\end{tabular}


Table 6.3 Metals sample conditions for FY-93 HVPM and cold cap test series.

\begin{tabular}{|l|l|c|c|c|l|}
\hline Test name & Date & $\begin{array}{c}\text { Sample } \\
\text { time }\end{array}$ & $\begin{array}{c}\text { Temperature } \\
\left({ }^{\circ} \mathrm{C}\right)\end{array}$ & $\begin{array}{c}\text { Power } \\
(\mathrm{kW})\end{array}$ & Alkali \\
\hline HVPM01 & $6 / 18 / 93$ & $27 \mathrm{~min}$ & 1220 & 16.2 & no \\
\hline & & $15 \mathrm{~min}$ & 1350,1460 & 24.0 & no \\
\hline HVPM02 & $6 / 23 / 93$ & $30 \mathrm{~min}$ & 1650 & 21.0 & no \\
\hline HVPM03 & $6 / 24 / 93$ & $17 \mathrm{~min}$ & 1900 & unk & no \\
\hline HVPM04 & $6 / 25 / 93$ & $0 \mathrm{~min}$ & & & $0.7 \mathrm{~kg}$ \\
\hline HVPM05 & $7 / 01 / 93$ & $30 \mathrm{~min}$ & 1600 & 18.0 & $0.7 \mathrm{~kg}$ \\
\hline & & $8 \mathrm{~min}$ & 1500 & 14.5 & $1.6 \mathrm{~kg}$ \\
\hline HVPM06 & $7 / 2 / 93$ & $6 \mathrm{~min}$ & 1740,1720 & 18.2 & no \\
\hline & & $11 \mathrm{~min}$ & 1420,1460 & 4.9 & no \\
\hline $\mathrm{CC} 01$ & $7 / 09 / 93$ & $16 \mathrm{~min}$ & $2300+$ & 18.8 & no \\
\hline $\mathrm{CC} 02$ & $7 / 13 / 93$ & $22 \mathrm{~min}$ & $1400,1350,1250$ & 3.2 & no \\
\hline $\mathrm{CC} 03$ & $7 / 14 / 93$ & $12 \mathrm{~min}$ & $1870-2000,1750$ & 12.8 & no \\
\hline $\mathrm{CC} 04$ & $7 / 15 / 93$ & $0 \mathrm{~min}$ & & & no \\
\hline $\mathrm{CC} 05$ & $7 / 16 / 93$ & $21 \mathrm{~min}$ & $2000-2100,2000$ & -14.9 & no \\
\hline
\end{tabular}

At the end of each sample collection period, after the final leak check was performed, the sample train assembly inlet and outlet were sealed, and the assembly was carried to a designated chemistry laboratory for sample recovery. Recovered samples were stored in glass jars and refrigerated until shipment to the analytical laboratory for analysis. 


\subsection{XRD Analysis of Exhaust Particulate}

Particulates collected in the cold trap and crucible wall were used to make some semiqualitative phase identifications using $\mathrm{x}$-ray diffraction techniques. In the case of a no-coldcap experiment $\mathrm{x}$-ray diffraction profiles of material from the crucible wall and from the cold trap were found to be very similar. This fact suggests that most of the chemistry, such as oxidation, etc., has taken place within the melt and shortly after leaving the melt surface. The nature of particulates remains basically the same as they traverse the top of the melter and out the exhaust system. The same conclusion can be made in regard to the cold cap runs for which the XRD analyses of particulates collected from the crucible wall and the cold trap are again very similar.

In addition to the usual $\mathrm{SiO}_{2}, \mathrm{TiO}_{2}, \mathrm{ZrO}_{2}$, and iron oxides, $\mathrm{CrO}, \mathrm{CdO}, \mathrm{ZnO}$, and $\mathrm{Sm}_{2} \mathrm{O}_{3}$ were identified. The original HVPM metal phases were not detected. The metals may have been oxidized while still in the melt or as they volatilized from the surface. Metal vapors just above the melt would be well above $500^{\circ} \mathrm{C}$ and easily oxidized by the incoming air. The $\mathrm{Cr}$ reaction would be different than that of other HVPMs in the melt. $\mathrm{Cr}$ metal is a strong reducing agent that can reduce the iron oxides in the melt to metal and itself will be oxidized to oxides. $\mathrm{Cr}_{2} \mathrm{O}_{3}$ can be dissociated at high temperature, particularly under the influence of an arc, to volatile suboxides such as $\mathrm{CrO}, \mathrm{CrO}_{2}$ or $\mathrm{CrO}_{3}$. The oxides of $\mathrm{Pb}$ and Cs were most likely present. However, they were not specifically identified by the XRD analysis in either cold cap or non cold cap cases.

\subsection{HVPM Tests: Analysis and Results}

\subsubsection{Slag Composition Evaluation}

In order to evaluate the extent of volatilization, it is necessary to compare the compositions of the starting materials with those of the final product or slag. Using the listed compositions of the IEB series in Table 2.2, the IEB4 compositions can be determined since known quantities of $\mathrm{TiO}_{2}$ and $\mathrm{ZrO}_{2}$ were added. Table 6.4 lists the IEB4 compositions and alkali mixture used in the experiments. $\mathrm{TiO}_{2}$ and $\mathrm{ZrO}_{2}$ additions were based on $10 \mathrm{wt} \%$ and $5 \mathrm{wt} \%$ loadings in the soil. The IEB4/A-80 therefore had total additions of $8 \mathrm{wt} \% \mathrm{TiO}_{2}$ and $4 \mathrm{wt} \% \mathrm{ZrO}_{2}$, and the IEB4/A-40 had total additions of $4 \mathrm{wt} \% \mathrm{TiO}_{2}$ and $2 \mathrm{wt} \% \mathrm{ZrO}_{2}$. The alkali mix was composed of $50 \mathrm{wt} \%$ IEB $4 / \mathrm{A}-40$ plus $33.3 \mathrm{wt} \% \mathrm{NaOH}$ and $16.7 \mathrm{wt} \% \mathrm{KOH}$. Materials added to the melts are mentioned in Table 6.2. 
Table 6.4 Chemical compositions for 1 kilogram of IEB4 mixes and alkali mix.

\begin{tabular}{|c|c|c|c|c|}
\hline $\begin{array}{c}\text { Chemical } \\
\text { constituent }\end{array}$ & $\begin{array}{c}\text { IEB4/A-80 } \\
\text { (grams) }\end{array}$ & $\begin{array}{c}\text { IEB } 4 / A-40 \\
\text { (grams) }\end{array}$ & $\begin{array}{l}\text { IEB } 4 / \mathrm{A}-40+\mathrm{H}+\mathrm{S} \\
\text { (grams) }\end{array}$ & $\begin{array}{c}\text { Alkali mix } \\
\text { (grams) }\end{array}$ \\
\hline $\mathrm{SiO}_{2}$ & 531.5 & 479.4 & 436.3 & 239.7 \\
\hline $\mathrm{Al}_{2} \mathrm{O}_{3}$ & 105.6 & 95.9 & 87.3 & 47.9 \\
\hline $\mathrm{Fe}_{\mathrm{x}} \mathrm{O}_{\mathrm{y}}$ & 82.7 & 183.3 & 166.8 & 91.7 \\
\hline $\mathrm{CaO}$ & 87.1 & 91.2 & 83.0 & 45.6 \\
\hline $\mathrm{MgO}$ & 24.6 & 32.9 & 29.9 & 16.5 \\
\hline $\mathrm{Na}_{2} \mathrm{O}$ & 19.4 & 30.1 & 27.4 & $348.3^{*}$ \\
\hline $\mathrm{K}_{2} \mathrm{O}$ & 24.6 & 24.4 & 22.2 & $178.9^{* *}$ \\
\hline $\mathrm{TiO}_{2}$ & 84.4 & 42.8 & 39.0 & 21.4 \\
\hline $\mathrm{ZrO}_{2}$ & 40.0 & 20.0 & 18.2 & 10.0 \\
\hline $\mathrm{Pb}$ & & & 10 & \\
\hline $\mathrm{Cd}$ & & & 10 & \\
\hline $\mathrm{Zn}$ & & & 10 & \\
\hline $\mathrm{Cr}$ & & & 10 & \\
\hline $\mathrm{CeO}_{2}$ & . & & 10 & \\
\hline $\mathrm{Sm}_{2} \mathrm{O}_{3}$ & & & 10 & \\
\hline $\mathrm{Gd}_{2} \mathrm{O}_{3}$ & & & 10 & \\
\hline $\mathrm{Nd}_{2} \mathrm{O}_{3}$ & & & 10 & \\
\hline $\mathrm{Cs}_{2} \mathrm{CO}_{3}$ & & & 10 & \\
\hline
\end{tabular}

* $-\mathrm{Na}_{2} \mathrm{O}$ and $\mathrm{NaOH}$ combined

** $-\mathrm{K}_{2} \mathrm{O}$ and $\mathrm{KOH}$ combined 
Table 6.5 Chemical composition of the FY-93 HVPM experiments.

\begin{tabular}{|c|c|c|c|c|}
\hline $\begin{array}{c}\text { Chemical } \\
\text { constituent }\end{array}$ & $\begin{array}{c}\text { HVPM02 } \\
\text { (grams) }\end{array}$ & $\begin{array}{c}\text { HVPM03 } \\
\text { (grams) }\end{array}$ & $\begin{array}{c}\text { HVPM05 } \\
\text { (grams) }\end{array}$ & $\begin{array}{c}\text { HVPM06 } \\
\text { (grams) }\end{array}$ \\
\hline $\mathrm{SiO}_{2}$ & 3625.37 & 3625.37 & 5113.91 & 7184.92 \\
\hline $\mathrm{Al}_{2} \mathrm{O}_{3}$ & 720.85 & 720.85 & 1018.56 & 1432.76 \\
\hline $\mathrm{Fe}_{\mathrm{x}} \mathrm{O}_{\mathrm{y}}$ & 663.12 & 663.12 & 1232.27 & 2024.13 \\
\hline $\mathrm{CaO}$ & 605.69 & 605.69 & 888.81 & 1282.71 \\
\hline $\mathrm{MgO}$ & 177.78 & 177.78 & 279.93 & 422.06 \\
\hline $\mathrm{Na}_{2} \mathrm{O}$ & 143.53 & 143.53 & 760.26 & 890.21 \\
\hline $\mathrm{K}_{2} \mathrm{O}$ & 170.08 & 170.08 & 507.64 & 613.22 \\
\hline $\mathrm{TiO}_{2}$ & 545.37 & 545.37 & 678.32 & 863.30 \\
\hline $\mathrm{ZrO}_{2}$ & 258.20 & 258.20 & 320.30 & 406.70 \\
\hline $\mathrm{Pb}$ & 10.00 & 10.00 & 30.00 & 50.00 \\
\hline $\mathrm{Cd}$ & 10.00 & 10.00 & 30.00 & 50.00 \\
\hline $\mathrm{Zn}_{\mathrm{Cr}}$ & 10.00 & 10.00 & 30.00 & 50.00 \\
\hline $\mathrm{CeO}_{2}$ & 10.00 & 10.00 & 30.00 & 50.00 \\
\hline $\mathrm{Sm}_{2} \mathrm{O}_{3}$ & 10.00 & 10.00 & 30.00 & 50.00 \\
\hline $\mathrm{Gd}_{2} \mathrm{O}_{3}$ & 10.00 & 10.00 & 30.00 & 50.00 \\
\hline $\mathrm{Nd}_{2} \mathrm{O}_{3}$ & 10.00 & 10.00 & 30.00 & 50.00 \\
\hline $\mathrm{Cs}_{2} \mathrm{CO}_{3}$ & 10.00 & 10.00 & 30.00 & 50.00 \\
\hline $\mathrm{Total}$ & 7000 & 7000 & 11070 & 15570 \\
\hline & & 10.00 & 30.00 & 50.00 \\
\hline
\end{tabular}

* Sodium hydroxide and potassium hydroxide were added to the melt to decrease viscosity. 


\subsubsection{Slag Characterization}

The chemical analyses for selected slag samples from HVPM 02, 03, 05, and 06 were examined to determine residual composition of primary and added constituents. In the case of HVPM06, two slag samples were analysed. Tables 6.6 through 6.11 list the input composition of material for each of the HVPM experiments and (in the next column) the metals basis in parts per million (ppm) for each compound. Analytical results for the slag composition in terms of metals concentrations in ppm are also listed. Due to varying mass losses for each compound during processing, however, direct comparison of input metals concentrations to those of the slag in order to directly determine mass losses will not work. One method that will adjust the input metals concentrations so they can be directly compared to the analytical results is to normalize the input metals concentrations with a metal that has undergone no mass loss during processing. These "corrected" values will only be as good as the assumption of no mass loss for the element used to normalize the data. One can verify this using a simple example with 4 or 5 elements (see last page of Appendix C). The percentage of loss for each element can be determined exactly if the data is normalized to an element that has undergone no mass loss. The results from using this normalization method are, of course, only as good as the assumption that all of one component remains in the final product. In general, the percentage of error in the final results are about the magnitude as any original error in the assumption of no mass loss. For instance, if $15 \%$ of the mass of the element used for normalization has actually been lost, the normalized values for the other elements will be off by approximately the same amount. These errors will be compounded by errors in the analytical data when the comparisons are made.

Zirconia and titania have the highest boiling points of all the compounds in the melt $\left(\mathrm{ZrO}_{2}-5000 \mathrm{C}, \mathrm{TiO}_{2}->2500 \mathrm{C}\right)$ and should, therefore, be more resistant to volatilization. Using $\mathrm{Ti}$ or $\mathrm{Zr}$ to normalize the data results in only a 1 or 2 percent difference in the "Amount retained" column in the tables. Titanium was chosen for the normalization in the HVPM experimental data since when $\mathrm{Zr}$ is used, it results in a greater than $100 \%$ amount retained for Ti. A ratio of the calculated metals basis concentration of titanium to the chemical analysis value was used to normalize the calculated metal concentrations. Appendix $\mathrm{C}$ contains the spread sheet work for the calculated compositions and normalization.

By comparing the corrected values with the slag metals analysis, the amount of each constituent compound retained can be determined. In Table 6.6 for HVPM02, the overall amount of material retained is approximately $50 \%$. This result, however, is known to be incorrect. Even accounting for mass losses from hydrates and carbonates into $\mathrm{H}_{2} \mathrm{O}$ and $\mathrm{CO}_{2}$ and volatilization from all the compounds, still upward of $85 \%$ of the original mass should be retained. This suggests that the analytical metals concentrations for $\mathrm{Ti}$ and $\mathrm{Zr}$ may be over- 
valued. This being the case, the ( $\mathrm{Ti}$ or $\mathrm{Zr}$ ) correction process would result in lowering the amount retained percentage of the other compounds below what they actually are.

Direct comparison of the calculated metals basis values with the slag metals analysis values, while inaccurate, is still useful for making some generalizations. This approach suggests that metals like $\mathrm{Si}, \mathrm{Al}, \mathrm{Ca}$, and $\mathrm{Mg}$ have increased slightly in percentage as expected. The HVPMs like $\mathrm{Pb}, \mathrm{Cd}$, and $\mathrm{Zn}$ have decreased as expected. The metals $\mathrm{Ti}$ and $\mathrm{Zr}$ and in some cases $\mathrm{Fe}$, have increased dramatically to twice or more their original concentrations. An increase in concentration is expected due to the loss of other constituents, but as stated in the previous paragraph, they appear to be abnormally high. The data contained in Table 6.6 for HVPM02 is consistent with the other HVPM experiments.

Some general conclusions concerning volatilization can still be drawn by direct examination of the analytical data. In all the HVPM experiments, the majority of $\mathrm{Pb}$ and $\mathrm{Cd}$ tended to volatilize. Zinc was also heavily volatilized but less so than for $\mathrm{Pb}$ and $\mathrm{Cd}$. Sodium also was heavily volatilized in most cases. Chromium apparently stayed in the melt as did the surrogates, $\mathrm{Ce}$ and $\mathrm{Sm}$. 
Table 6.6 HVPM02 slag materials characterization.

\begin{tabular}{|c|c|c|c|c|c|}
\hline \multicolumn{6}{|c|}{ HVPM02 } \\
\hline & $\begin{array}{c}\text { Final } \\
\text { composition } \\
\text { (grams) }\end{array}$ & $\begin{array}{l}\text { Metals } \\
\text { basis } \\
\text { (ppm) }\end{array}$ & $\begin{array}{l}\text { Correct with } \\
\text { titanium } \\
\text { (ppm) }\end{array}$ & $\begin{array}{l}\text { Slag metals } \\
\text { analysis } \\
\text { (ppm) }\end{array}$ & $\begin{array}{c}\text { Amount } \\
\text { retained } \\
(\%)\end{array}$ \\
\hline $\mathrm{SiO}_{2}$ & 3625.37 & 241864 & 554544 & 276000 & 50 \\
\hline $\mathrm{Al}_{2} \mathrm{O}_{3}$ & 720.85 & 54476 & 124901 & 54300 & 43 \\
\hline $\mathrm{Fe}_{\mathrm{x}} \mathrm{O}_{\mathrm{y}}$ & 663.12 & 66217 & 151823 & 161000 & 106 \\
\hline $\mathrm{CaO}$ & 605.69 & 61867 & 141848 & 96400 & 68 \\
\hline $\mathrm{MgO}$ & 177.78 & 15314. & 35113 & 20100 & 57 \\
\hline $\mathrm{Na}_{2} \mathrm{O}$ & 143.53 & 15214 & 34883 & 5150 & 15 \\
\hline $\mathrm{K}_{2} \mathrm{O}$ & 170.08 & 20167 & 46238 & 24900 & 54 \\
\hline $\mathrm{TiO}_{2}$ & 545.37 & 46668 & 107000 & 107000 & 100 \\
\hline $\mathrm{ZrO}_{2}$ & 258.20 & 27295 & 62583 & 53900 & 86 \\
\hline $\mathrm{Pb}$ & 10.00 & 1429 & 3275 & 262 & 8 \\
\hline $\mathrm{Cd}$ & 10.00 & 1429 & 3275 & 463 & 14 \\
\hline $\mathrm{Zn}$ & 10.00 & 1429 & 3275 & $\therefore \quad 1320$ & 40 \\
\hline $\mathrm{Cr}$ & 10.00 & 1429 & 3275 & 1550 & 47 \\
\hline $\mathrm{CeO}_{2}$ & 10.00 & 1163 & 2666 & 1220 & 46 \\
\hline $\mathrm{Sm}_{2} \mathrm{O}_{3}$ & 10.00 & 1231 & 2823 & 1210 & 43 \\
\hline $\mathrm{Gd}_{2} \mathrm{O}_{3}$ & 10.00 & 1224 & 2843 & 1190 & 42 \\
\hline $\mathrm{Nd}_{2} \mathrm{O}_{3}$ & 10.00 & 1166 & 2807 & 1250 & 45 \\
\hline $\mathrm{Cs}_{2} \mathrm{CO}_{3}$ & 10.00 & 1171 & 2673 & 1210 & 45 \\
\hline
\end{tabular}


Table 6.7 HVPM03 Slag Materials Characterization.

\begin{tabular}{|c|c|c|c|c|c|}
\hline \multicolumn{6}{|c|}{ HVPM03 } \\
\hline & $\begin{array}{c}\text { Final } \\
\text { composition } \\
\text { (grams) }\end{array}$ & $\begin{array}{l}\text { Metals } \\
\text { basis } \\
\text { (ppm) }\end{array}$ & $\begin{array}{l}\text { Correct with } \\
\text { titanium } \\
\text { (ppm) }\end{array}$ & $\begin{array}{c}\text { Slag metals } \\
\text { analysis } \\
\text { (ppm) }\end{array}$ & $\begin{array}{c}\text { Amount } \\
\text { retained } \\
(\%)\end{array}$ \\
\hline $\mathrm{SiO}_{2}$ & 3625.37 & 241864 & 689294 & 261000 & 38 \\
\hline $\mathrm{Al}_{2} \mathrm{O}_{3}$ & 720.85 & 54476 & 155251 & 56900 & 37 \\
\hline $\mathrm{Fe}_{\mathrm{x}} \mathrm{O}_{\mathrm{y}}$ & 663.12 & 66217 & 188714 & 116000 & 61 \\
\hline $\mathrm{CaO}$ & 605.69 & 61867 & 176316 & 90600 & 51 \\
\hline $\mathrm{MgO}$ & 177.78 & 15314 & 43645 & 21500 & 49 \\
\hline $\mathrm{Na}_{2} \mathrm{O}$ & 143.53 & 15214 & 43359 & 2500 & 6 \\
\hline $\mathrm{K}_{2} \mathrm{O}$ & 170.08 & 20167 & 57473 & 21400 & 37 \\
\hline $\mathrm{TiO}_{2}$ & 545.37 & 46668 & 133000 & 133000 & 100 \\
\hline $\mathrm{ZrO}_{2}$ & 258.20 & 27295 & 77790 & 69700 & 90 \\
\hline $\mathrm{Pb}$ & 10.00 & 1429 & 4071 & 549 & 13 \\
\hline $\mathrm{Cd}$ & 10.00 & 1429 & 4071 & 463 & 11 \\
\hline $\mathrm{Zn}$ & 10.00 & 1429 & 4071 & 940 & 23 \\
\hline $\mathrm{Cr}$ & 10.00 & 1429 & 4071 & 1800 & 44 \\
\hline $\mathrm{CeO}_{2}$ & 10.00 & 1163 & 3314 & 1600 & 48 \\
\hline $\mathrm{Sm}_{2} \mathrm{O}_{3}$ & 10.00 & 1231 & 3509 & 1460 & 42 \\
\hline $\mathrm{Gd}_{2} \mathrm{O}_{3}$ & 10.00 & 1224 & 3534 & 1550 & 44 \\
\hline $\mathrm{Nd}_{2} \mathrm{O}_{3}$ & 10.00 & 1166 & 3489 & 1450 & 42 \\
\hline $\mathrm{Cs}_{2} \mathrm{CO}_{3}$ & 10.00 & 1171 & 3322 & 1210 & 36 \\
\hline
\end{tabular}


Table 6.8 HVPM05 slag materials characterization.

\begin{tabular}{|c|c|c|c|c|c|}
\hline \multicolumn{7}{|c|}{} & $\begin{array}{c}\text { Final } \\
\text { composition } \\
\text { (grams) }\end{array}$ & $\begin{array}{c}\text { Metals } \\
\text { basis } \\
\text { (ppm) }\end{array}$ & $\begin{array}{c}\text { Correct with } \\
\text { titanium } \\
\text { (ppm) }\end{array}$ & $\begin{array}{c}\text { Slag metals } \\
\text { analysis } \\
\text { (ppm) }\end{array}$ & $\begin{array}{c}\text { Amount } \\
\text { retained } \\
(\%)\end{array}$ \\
\hline $\mathrm{SiO}_{2}$ & 5113.91 & 215736 & 670060 & 262000 & 39 \\
\hline $\mathrm{Al}_{2} \mathrm{O}_{3}$ & 1018.6 & 48674 & 151177 & 52900 & 35 \\
\hline $\mathrm{Fe}_{\mathrm{x}} \mathrm{O}_{\mathrm{y}}$ & 1232.27 & 77810 & 241672 & 97600 & 40 \\
\hline $\mathrm{CaO}$ & 888.81 & 57407 & 178303 & 70800 & 40 \\
\hline $\mathrm{MgO}$ & 279.93 & 15248 & 47360 & 19200 & 41 \\
\hline $\mathrm{Na}_{2} \mathrm{O}$ & 760.26 & 50959 & 158274 & 22700 & 14 \\
\hline $\mathrm{K}_{2} \mathrm{O}$ & 507.64 & 38062 & 118216 & 26400 & 22 \\
\hline $\mathrm{TiO}_{2}$ & 678.32 & 36704 & 114000 & 114000 & 100 \\
\hline $\mathrm{ZrO}_{2}$ & 320.30 & 21411 & 66502 & 60000 & 90 \\
\hline $\mathrm{Pb}$ & 30.00 & 2710 & 8417 & 524 & 6 \\
\hline $\mathrm{Cd}$ & 30.00 & 2710 & 8417 & 210 & 2 \\
\hline $\mathrm{Zn}$ & 30.00 & 2710 & 8417 & 1420 & 17 \\
\hline $\mathrm{Cr}$ & 30.00 & 2710 & 8417 & 3130 & 37 \\
\hline $\mathrm{CeO}_{2}$ & 30.00 & 2206 & 6852 & 2960 & 43 \\
\hline $\mathrm{Sm}_{2} \mathrm{O}_{3}$ & 30.00 & 2336 & 7256 & 2700 & 37 \\
\hline $\mathrm{Gd}_{2} \mathrm{O}_{3}$ & 30.00 & 2352 & 7306 & 2880 & 39 \\
\hline $\mathrm{Nd}_{2} \mathrm{O}_{3}$ & 30.00 & 2322 & 7213 & 2880 & 40 \\
\hline $\mathrm{Cs}_{2} \mathrm{CO}_{3}$ & 30.00 & 2211 & 6868 & 2310 & 34 \\
\hline
\end{tabular}


Table 6.9 HVPM06-01 Slag Materials Characterization.

\begin{tabular}{|c|c|c|c|c|c|}
\hline \multicolumn{6}{|c|}{ HVPM06-01 } \\
\hline & $\begin{array}{c}\text { Final } \\
\text { composition } \\
\text { (grams) }\end{array}$ & $\begin{array}{c}\text { Metals } \\
\text { basis } \\
\text { (ppm) }\end{array}$ & $\begin{array}{l}\text { Correct with } \\
\text { titanium } \\
\text { (ppm) }\end{array}$ & $\begin{array}{l}\text { Slag metals } \\
\text { analysis } \\
\text { (ppm) }\end{array}$ & $\begin{array}{c}\text { Amount } \\
\text { retained } \\
(\%)\end{array}$ \\
\hline $\mathrm{SiO}_{2}$ & 7184.92 & 215501 & 700775 & 280000 & 40 \\
\hline $\mathrm{Al}_{2} \mathrm{O}_{3}$ & 1432.76 & 48679 & 158296 & 50100 & 32 \\
\hline $\mathrm{Fe}_{\mathrm{x}} \mathrm{O}_{\mathrm{y}}$ & 2024.13 & 90871 & 295499 & 127000 & 43 \\
\hline $\mathrm{CaO}$ & 1282.71 & 58904 & 191547 & 70500 & 37 \\
\hline $\mathrm{MgO}$ & 422.06 & 16346 & 53153 & 18000 & 34 \\
\hline $\mathrm{Na}_{2} \mathrm{O}$ & 890.21 & 45401 & 137955 & 45000 & 33 \\
\hline $\mathrm{K}_{2} \mathrm{O}$ & 613.22 & 32689 & 106300 & 41600 & 39 \\
\hline $\mathrm{TiO}_{2}$ & 863.30 & 33212 & 108000 & 108000 & 100 \\
\hline $\mathrm{ZrO}_{2}$ & 406.70 & 19329 & 62856 & 58500 & 93 \\
\hline $\mathrm{Pb}$ & 50.00 & 3211 & 10443 & 587 & 6 \\
\hline $\mathrm{Cd}$ & 50.00 & 3211 & 10443 & 125 & 1 \\
\hline $\mathrm{Zn}$ & 50.00 & 3211 & 10443 & 1620 & 16 \\
\hline $\mathrm{Cr}$ & 50.00 & 3211 & 10443 & 4030 & 39 \\
\hline $\mathrm{CeO}_{2}$ & 50.00 & 2614 & 8500 & 2840 & 33 \\
\hline $\mathrm{Sm}_{2} \mathrm{O}_{3}$ & 50.00 & 2768 & 9002 & 3390 & 38 \\
\hline $\mathrm{Gd}_{2} \mathrm{O}_{3}$ & 50.00 & 2787 & 9064 & 3610 & 40 \\
\hline $\mathrm{Nd}_{2} \mathrm{O}_{3}$ & 50.00 & 2752 & 8949 & 3540 & 40 \\
\hline $\mathrm{Cs}_{2} \mathrm{CO}_{3}$ & 50.00 & 2620 & 8521 & 2840 & 33 \\
\hline
\end{tabular}


Table 6.10 HVPM06-02 Slag Materials Characterization.

\begin{tabular}{|c|c|c|c|c|c|}
\hline \multicolumn{7}{|c|}{ HVM06-02 } \\
\hline $\begin{array}{c}\text { Final } \\
\text { composition } \\
\text { (grams) }\end{array}$ & $\begin{array}{c}\text { Metals } \\
\text { basis } \\
\text { (ppm) }\end{array}$ & $\begin{array}{c}\text { Correct with } \\
\text { titanium } \\
\text { (ppm) }\end{array}$ & $\begin{array}{c}\text { Slag metals } \\
\text { analysis } \\
\text { (ppm) }\end{array}$ & $\begin{array}{c}\text { Amount } \\
\text { retained } \\
\text { (\%) }\end{array}$ \\
\hline $\mathrm{SiO}_{2}$ & 7184.92 & 215501 & 687798 & 192000 & 32 \\
\hline $\mathrm{Al}_{2} \mathrm{O}_{3}$ & 1432.76 & 48679 & 155364 & 49800 & 36 \\
\hline $\mathrm{Fe}_{\mathrm{x}} \mathrm{O}_{\mathrm{y}}$ & 2024.13 & 90871 & 290026 & 199000 & 78 \\
\hline $\mathrm{CaO}$ & 1282.71 & 58904 & 187999 & 72500 & 44 \\
\hline $\mathrm{MgO}$ & 422.06 & 16346 & 52169 & 20000 & 44 \\
\hline $\mathrm{Na}_{2} \mathrm{O}$ & 890.21 & 45401 & 135400 & 21000 & 18 \\
\hline $\mathrm{K}_{2} \mathrm{O}$ & 613.22 & 32689 & 104332 & 30300 & 33 \\
\hline $\mathrm{TiO}_{2}$ & 863.30 & 33212 & 106001 & 106000 & 100 \\
\hline $\mathrm{ZrO}_{2}$ & 406.70 & 19329 & 61692 & 54200 & 88 \\
\hline $\mathrm{Pb}$ & $50: 00$ & 3211 & 10249 & 589 & 6 \\
\hline $\mathrm{Cd}$ & 50.00 & 3211 & 10249 & 147 & 1 \\
\hline $\mathrm{Zn}$ & 50.00 & 3211 & 10249 & 1320 & 13 \\
\hline $\mathrm{Cr}$ & 50.00 & 3211 & 10249 & 3310 & 32 \\
\hline $\mathrm{CeO}_{2}$ & 50.00 & 2614 & 8343 & 2860 & 34 \\
\hline $\mathrm{Sm}_{2} \mathrm{O}_{3}$ & 50.00 & 2768 & 3534 & 2660 & 75 \\
\hline $\mathrm{Gd}_{2} \mathrm{O}_{3}$ & 50.00 & 2787 & 8896 & 2800 & 31 \\
\hline $\mathrm{Nd}_{2} \mathrm{O}_{3}$ & 50.00 & 2752 & 8784 & 2820 & 32 \\
\hline $\mathrm{Cs}_{2} \mathrm{CO}_{3}$ & 50.00 & 2620 & 8363 & 2230 & 27 \\
\hline & & & & & \\
\hline
\end{tabular}




\subsection{Cold Cap Tests: Analysis and Results}

\subsubsection{Slag Characterization}

Tables 6.11 through 6.14 show the slag analysis results for the cold cap tests. The same normalization technique described above was again used except in this case $\mathrm{Zr}$ was used for the normalization rather than $\mathrm{Ti}$. If $\mathrm{Ti}$ were to be used, it would result in a greater than $100 \%$ amount retained for $\mathrm{Zr}$, with the exception of $\mathrm{CC} 03$.

In general the results are very similar to the HVPM experiments. Once again the amount retained percentages for most elements are far lower than expected using the Ti-corrected values, and therefore direct comparison of analytic values to the calculated (metals basis) values will be used to make some general conclusions. In all the cold cap experiments, the majority of $\mathrm{Pb}$ and $\mathrm{Cd}$ tended to volatilize. Zinc was also heavily volatilized but less so than for $\mathrm{Pb}$ and $\mathrm{Cd}$. Again, $\mathrm{Na}$ was heavily volatilized for each of the cold cap experiments. Chromium tended to remain in the melt as did the surrogates, Ce and Sm.

Direct comparison of the open melt (HVPM) data and the cold cap (CC) data show a slight decrease in the amount of $\mathrm{Pb}$ and $\mathrm{Cd}$ volatilization. This can be seen most easily by comparing the analytical results directly. The concentrations of $\mathrm{Pb}$ and $\mathrm{Cd}$ in the slag are just slightly higher overall in the cold cap experiments. This is true also for $\mathrm{Zn}$ and $\mathrm{Cr}$. For these tests, there is no discernable effect of the cold cap on surrogate element retention in the slag. 
Table 6.11 Cold-cap CC01 slag materials characterization.

\begin{tabular}{|c|c|c|c|c|c|}
\hline \multicolumn{7}{|c|}{} & $\begin{array}{c}\text { Final } \\
\text { composition } \\
\text { (grams) }\end{array}$ & $\begin{array}{c}\text { Metals } \\
\text { basis } \\
\text { (ppm) }\end{array}$ & $\begin{array}{c}\text { Correct with } \\
\text { zirconium } \\
\text { (ppm) }\end{array}$ & $\begin{array}{c}\text { Slag metals } \\
\text { analysis } \\
\text { (ppm) }\end{array}$ & $\begin{array}{c}\text { Amount } \\
\text { retained } \\
(\%)\end{array}$ \\
\hline $\mathrm{SiO}_{2}$ & 6512.26 & 224147 & 676207 & 231000 & 34 \\
\hline $\mathrm{Al}_{2} \mathrm{O}_{3}$ & 1298.23 & 50616 & 152700 & 54400 & 36 \\
\hline $\mathrm{Fe}_{\mathrm{x}} \mathrm{O}_{\mathrm{y}}$ & 1766.93 & 91029 & 274617 & 186000 & 68 \\
\hline $\mathrm{CaO}$ & 1154.77 & 60854 & 183583 & 71400 & 39 \\
\hline $\mathrm{MgO}^{2}$ & 375.90 & 16706 & 50399 & 17900 & 36 \\
\hline $\mathrm{Na}_{2} \mathrm{O}$ & 324.67 & 17755 & 53565 & 2500 & 5 \\
\hline $\mathrm{K}_{2} \mathrm{O}$ & 317.26 & 19408 & 58550 & 21500 & 37 \\
\hline $\mathrm{TiO}_{2}$ & 803.22 & 35461 & 106978 & 103000 & 96 \\
\hline $\mathrm{ZrO}_{2}$ & 378.64 & 20651 & 62300 & 62300 & 100 \\
\hline $\mathrm{Pb}^{2}$ & 70.68 & 5209 & 15715 & 1940 & 12 \\
\hline $\mathrm{Cd}$ & 70.68 & 5209 & 15715 & 805 & 5 \\
\hline $\mathrm{Zn}$ & 70.68 & 5209 & 15715 & 3240 & 21 \\
\hline $\mathrm{Cr}$ & 70.68 & 5209 & 15715 & 5790 & 37 \\
\hline $\mathrm{CeO}_{2}$ & 70.68 & 4240 & 12792 & 3960 & 31 \\
\hline $\mathrm{Sm}_{2} \mathrm{O}_{3}$ & 70.68 & 4490 & 13547 & 3700 & 27 \\
\hline $\mathrm{Gd}_{2} \mathrm{O}_{3}$ & 70.68 & 4522 & 13641 & 3840 & 28 \\
\hline $\mathrm{Nd}_{2} \mathrm{O}_{3}$ & 70.68 & 4464 & 13468 & 4020 & 30 \\
\hline $\mathrm{Cs}_{2} \mathrm{CO}_{3}$ & 70.68 & 4251 & 12824 & 4030 & 31 \\
\hline & & & & & \\
\hline
\end{tabular}


Table 6.12 Cold-cap CC02 slag materials characterization.

\begin{tabular}{|c|c|c|c|c|c|}
\hline \multicolumn{7}{|c|}{} & $\begin{array}{c}\text { Final } \\
\text { Composition } \\
\text { (grams) }\end{array}$ & $\begin{array}{c}\text { Metals } \\
\text { basis } \\
\text { (ppm) }\end{array}$ & $\begin{array}{c}\text { Correct with } \\
\text { zirconium } \\
\text { (ppm) }\end{array}$ & $\begin{array}{c}\text { Slag metals } \\
\text { analysis } \\
\text { (ppm) }\end{array}$ & $\begin{array}{c}\text { Amount } \\
\text { retained } \\
\text { (\%) }\end{array}$ \\
\hline $\mathrm{SiO}_{2}$ & 4583.39 & 232758 & 613083 & 225000 & 37 \\
\hline $\mathrm{Al}_{2} \mathrm{O}_{3}$ & 912.45 & 52489 & 138255 & 58100 & 42 \\
\hline $\mathrm{Fe}_{\mathrm{x}} \mathrm{O}_{\mathrm{y}}$ & 1029.42 & 78248 & 206103 & 169000 & 82 \\
\hline $\mathrm{CaO}$ & 787.90 & 61260 & 161359 & 71300 & 44 \\
\hline $\mathrm{MgO}$ & 243.53 & 15969 & 42062 & 20600 & 49 \\
\hline $\mathrm{Na}_{2} \mathrm{O}$ & 203.64 & 16431 & 43280 & 2500 & 6 \\
\hline $\mathrm{K}_{2} \mathrm{O}$ & 218.92 & 19759 & 52045 & 20700 & 40 \\
\hline $\mathrm{TiO}_{2}$ & 630.94 & 41098 & 108251 & 103000 & 95 \\
\hline $\mathrm{ZrO}_{2}$ & 298.17 & 23994 & 63199 & 62300 & 100 \\
\hline $\mathrm{Pb}$ & 31.96 & 3475 & 9154 & 1100 & 12 \\
\hline $\mathrm{Cd}$ & 31.96 & 3475 & 9154 & 482 & 5 \\
\hline $\mathrm{Zn}_{\mathrm{Cr}}$ & 31.96 & 3475 & 9154 & 2440 & 27 \\
\hline $\mathrm{Cr}$ & 31.96 & 3475 & 9154 & 2090 & 23 \\
\hline $\mathrm{CeO}_{2}$ & 31.96 & 2829 & 7452 & 1840 & 25 \\
\hline $\mathrm{Sm}_{2} \mathrm{O}_{3}$ & 31.96 & 2996 & 7891 & 1640 & 21 \\
\hline $\mathrm{Gd}_{2} \mathrm{O}_{3}$ & 31.96 & 3017 & 7946 & 1740 & 22 \\
\hline $\mathrm{Nd}_{2} \mathrm{O}_{3}$ & 31.96 & 2978 & 7845 & 1720 & 22 \\
\hline $\mathrm{Cs}_{2} \mathrm{CO}_{3}$ & 31.96 & 2836 & 7470 & 1760 & 24 \\
\hline
\end{tabular}


Table 6.13 Cold-cap CC03 slag materials characterization.

\begin{tabular}{|c|c|c|c|c|c|}
\hline \multicolumn{7}{|c|}{} & $\begin{array}{c}\text { Final } \\
\text { composition } \\
\text { (grams) }\end{array}$ & $\begin{array}{c}\text { Metals } \\
\text { basis } \\
\text { (ppm) }\end{array}$ & $\begin{array}{c}\text { Correct with } \\
\text { zirconium } \\
\text { (ppm) }\end{array}$ & $\begin{array}{c}\text { Slag metals } \\
\text { analysis } \\
\text { (ppm) }\end{array}$ & $\begin{array}{c}\text { Amount } \\
\text { retained } \\
\text { (\%) }\end{array}$ \\
\hline $\mathrm{SiO}_{2}$ & 5563.27 & 222359 & 505554 & 230000 & 45 \\
\hline $\mathrm{Al}_{2} \mathrm{O}_{3}$ & 1108.43 & 50185 & 114100 & 58300 & 51 \\
\hline $\mathrm{Fe}_{\mathrm{x}} \mathrm{O}_{\mathrm{y}}$ & 1404.08 & 84000 & 190981 & 152000 & 80 \\
\hline $\mathrm{CaO}$ & 974.27 & 59620 & 135552 & 81700 & 60 \\
\hline $\mathrm{MgO}$ & 310.77 & 16039 & 36465 & 23500 & 64 \\
\hline $\mathrm{Na}_{2} \mathrm{O}$ & 265.13 & 16837 & 38281 & 2780 & 7 \\
\hline $\mathrm{K}_{2} \mathrm{O}$ & 268.88 & 19101 & 43427 & 20600 & 47 \\
\hline $\mathrm{TiO}_{2}$ & 778.99 & 39936 & 90799 & 108000 & 119 \\
\hline $\mathrm{ZrO}_{2}$ & 498.62 & 31580 & 71800 & 71800 & 100 \\
\hline $\mathrm{Pb}$ & 56.84 & 4865 & 11061 & 1130 & 10 \\
\hline $\mathrm{Cd}$ & 56.84 & 4865 & 11061 & 125 & 1 \\
\hline $\mathrm{Zn}$ & 56.84 & 4865 & 11061 & 1440 & 13 \\
\hline $\mathrm{Cr}$ & 56.84 & 4865 & 11061 & 4800 & 43 \\
\hline $\mathrm{CeO}_{2}$ & 56.84 & 3960 & 9003 & 4100 & 46 \\
\hline $\mathrm{Sm}_{2} \mathrm{O}_{3}$ & 56.84 & 4193 & 9534 & 3780 & 40 \\
\hline $\mathrm{Gd}_{2} \mathrm{O}_{3}$ & 56.84 & 4223 & 9601 & 3990 & 42 \\
\hline $\mathrm{Nd}_{2} \mathrm{O}_{3}$ & 56.84 & 4169 & 9479 & 3930 & 41 \\
\hline $\mathrm{Cs}_{2} \mathrm{CO}_{3}$ & 56.84 & 3970 & 9025 & 3830 & 42 \\
\hline & & & & & \\
\hline
\end{tabular}


Table 6.14 Cold-cap CC05 slag materials characterization.

\begin{tabular}{|c|c|c|c|c|c|}
\hline \multicolumn{6}{|c|}{$\mathrm{CC} 05$} \\
\hline & $\begin{array}{c}\text { Final } \\
\text { composition } \\
\text { (grams) }\end{array}$ & $\begin{array}{c}\text { Metals } \\
\text { basis } \\
\text { (ppm) }\end{array}$ & $\begin{array}{l}\text { Correct with } \\
\text { zirconium } \\
\text { (ppm) }\end{array}$ & $\begin{array}{c}\text { Slag metals } \\
\text { analysis } \\
\text { (ppm) }\end{array}$ & $\begin{array}{c}\text { Amount } \\
\text { retained } \\
(\%)\end{array}$ \\
\hline $\mathrm{SiO}_{2}$ & 4872.83 & 222359 & 574481 & 255000 & 44 \\
\hline $\mathrm{Al}_{2} \mathrm{O}_{3}$ & 970.34 & 50185 & 129586 & 58800 & 45 \\
\hline $\mathrm{Fe}_{\mathrm{x}} \mathrm{O}_{\mathrm{y}}$ & 1140.09 & 84000 & 201184 & 220000 & 109 \\
\hline $\mathrm{CaO}$ & 842.95 & 59620 & 152155 & 78200 & 51 \\
\hline $\mathrm{MgO}$ & 263.39 & 16039 & 40095 & 21100 & 53 \\
\hline $\mathrm{Na}_{2} \mathrm{O}$ & 221.80 & 16837 & 41547 & 2500 & 6 \\
\hline $\mathrm{K}_{2} \mathrm{O}$ & 233.68 & 19101 & 48964 & 16300 & 33 \\
\hline $\mathrm{TiO}_{2}$ & 699.71 & 39936 & 105809 & 91000 & 83 \\
\hline $\mathrm{ZrO}_{2}$ & 423.41 & 31580 & 79099 & 79100 & 100 \\
\hline $\mathrm{Pb}$ & 40.31 & 4865 & 10176 & 2170 & 21 \\
\hline $\mathrm{Cd}$ & 40.31 & 4865 & .10176 & 464 & 5 \\
\hline $\mathrm{Zn}$ & 40.31 & 4865 & 10176 & 5400 & 53 \\
\hline $\mathrm{Cr}$ & 40.31 & 4865 & 10176 & 6340 & 62 \\
\hline $\mathrm{CeO}_{2}$ & 40.31 & 3960 & 8284 & 5240 & 63 \\
\hline $\mathrm{Sm}_{2} \mathrm{O}_{3}$ & 40.31 & 4193 & 8772 & 5080 & 58 \\
\hline $\mathrm{Gd}_{2} \mathrm{O}_{3}$ & 40.31 & 4223 & 8833 & 5440 & 62 \\
\hline $\mathrm{Nd}_{2} \mathrm{O}_{3}$ & 40.31 & 4169 & 8721 & 5400 & 62 \\
\hline $\mathrm{Cs}_{2} \mathrm{CO}_{3}$ & 40.31 & 3970 & 8304 & 5510 & 66 \\
\hline
\end{tabular}




\subsection{Exhaust Particulate Composition}

Table 6.15 presents the chemical analysis results obtained for a combination of material collected on the filter and trapped in the liquid in the bubblers for HVPM runs. The volatile heavy metals, cadmium, lead, and zinc were found in the highest concentration. The amount of each metal for a particular run varied, but all were significantly higher in concentration than the next highest metal which was cesium. As indicated by the analyses, rare earth elements were also found in the particulate samples, but their concentration was significantly less than cadmium, cesium, lead, and zinc.

Particulate analyses for the cold cap runs are given in Table 6.16. With the exception of the $\mathrm{CC} 01$ run, the particulate obtained from the cold cap runs has slightly less cesium, lead, and zinc relative to that found for the HVPM runs.

The high levels of lead, cadmium and zinc in the exhaust particulates indicate that significant volatilization of these elements has taken place. The competing process for carryover of material, which is entrainment of feed material, would contribute much less of these elements, consistent with the amounts in the feed (less than $1 \mathrm{wt} \%$ ). The significant levels of these HVPM's, $27 \mathrm{wt} \%$ in the case of $\mathrm{Cd}$ for CC01, can only be the result of volatilization. 
Table 6.15 FY-93 HVPM experiments - particulate elemental analysis.

\begin{tabular}{|c|c|c|c|c|c|}
\hline Metal & $\begin{array}{c}\text { HVPM02 } \\
(\mathrm{ppm})\end{array}$ & $\begin{array}{c}\text { HVPM03 } \\
(\mathrm{ppm})\end{array}$ & $\begin{array}{c}\text { HVPM05 } \\
(\mathrm{ppm})\end{array}$ & $\begin{array}{c}\text { HVPM06-1 } \\
(\mathrm{ppm})\end{array}$ & $\begin{array}{c}\text { HVPM06-2 } \\
(\mathrm{ppm})\end{array}$ \\
\hline $\mathrm{Cd}$ & 94700 & 44900 & 66600 & 20600 & 19100 \\
\hline $\mathrm{Cr}$ & 326 & 226 & 862 & 1230 & 888 \\
\hline $\mathrm{Pb}$ & 136000 & 47300 & 71300 & 16200 & 2550 \\
\hline $\mathrm{Zn}$ & 99100 & 58100 & 57400 & 33800 & 3200 \\
\hline $\mathrm{Cs}$ & 16400 & 7390 & 12400 & 9900 & 1200 \\
\hline $\mathrm{Ce}$ & 623 & 569 & 424 & 141 & 50 \\
\hline $\mathrm{Gd}$ & 1010 & 1070 & 549 & 185 & 50 \\
\hline $\mathrm{Nd}$ & 924 & 1220 & 558 & 179 & 50 \\
\hline $\mathrm{Sm}$ & 698 & 756 & 512 & 177 & 5 \\
\hline
\end{tabular}

Table 6.16 FY-93 cold cap experiments - particulate elemental analysis.

\begin{tabular}{|c|c|c|c|c|}
\hline Metal & $\begin{array}{c}\mathrm{CC01} \\
(\mathrm{ppm})\end{array}$ & $\begin{array}{c}\mathrm{CC02} \\
(\mathrm{ppm})\end{array}$ & $\begin{array}{c}\mathrm{CC} 03 \\
(\mathrm{ppm})\end{array}$ & $\begin{array}{c}\mathrm{CC05} \\
(\mathrm{ppm})\end{array}$ \\
\hline $\mathrm{Cd}$ & 270000 & 81600 & 111000 & 158000 \\
\hline $\mathrm{Cr}$ & 114 & 50 & 50 & 50 \\
\hline $\mathrm{Pb}$ & 223000 & 11700 & 56400 & 14100 \\
\hline $\mathrm{Zn}$ & 133000 & 10700 & 21000 & 17600 \\
\hline $\mathrm{Cs}$ & 11300 & 489 & 1650 & 6550 \\
\hline $\mathrm{Ce}$ & 288 & 318 & 103 & 592 \\
\hline $\mathrm{Gd}$ & 4550 & 1040 & 1010 & 9440 \\
\hline $\mathrm{Nd}$ & 4360 & 728 & 1110 & 11400 \\
\hline $\mathrm{Sm}$ & 4210 & 919 & 863 & 9130 \\
\hline
\end{tabular}




\subsection{Volatilization Rates}

Data gathered during the exhaust gas sampling included the total off-gas.sample volume and temperature, ambient temperature, barometric pressure, differential pressure drop across the sample train, sampling time, etc. With this data the amount of volatilization for the HVPMs and surrogates, averaged over the sample time, can be calculated once the sampling train solutions have been analyzed. Calculations were done on a spread sheet, and Appendix D contains a printout. The results are in units of $\mathrm{lb} / \mathrm{hr}$ and $\mathrm{kg} / \mathrm{hr}$, and they have been converted to units of $\mathrm{mg} / \mathrm{hr}$ in Tables 6.17 through 6.20 below.

Volatilization rates listed in the tables are specific only to the INEL arc melter, since the geometry and temperature profiles within the melter will influence volatilization. Primary factors affecting the volatilization rate are the amount of slag in the melter, slag surface area, concentration of the volatile material in the slag, and slag temperature. Actual volatilization rates may actually be much higher since volatilized material condenses on the walls of the melt chamber and exhaust lines and this material will not be captured downstream by the sampling train. Condensed particulates and entrained particulates on which volatilized metals have condensed also collect on surfaces inside the melter. This further reduces the total load of volatilized material reaching the sampler, which would in turn cause an underestimation of the actual volatilization rate.

Examination of the data in the tables reveals in general the expected correlation between temperature and volatilization, i.e., the higher the temperature the higher the rate of volatilization, although there are exceptions. Lack of a strict correlation between temperature and volatilization rates may be related to the uncertainty in temperature and to unknown HVPM and surrogate concentrations in the slag at the specific time the sampling was done. The averaged temperatures consist of only two or three individual measurements. In the experiments where only one temperature measurement was made, the associated uncertainty in that temperature must be assumed to be quite large.

There appears to be no definite correlation for reduction of volatilization in the cold cap melts vs. the open melts. In fact the volatilization rate for specific elements is higher in many cases for the cold cap melts. This may be related to how the feed material is distributed in the melt. In the open melt case, the waste feed material (IEB4/A-40 plus HVPMs and surrogates) was slowly introduced into the melter allowing the feed to quickly melt into the slag and become well distributed. In the cold cap case, the waste feed is quickly fed in to cover the surface of the melt. The cold cap melts from underneath, and this may cause higher concentrations of HVPMs and surrogates near the melt surface resulting in higher volatilization rates, even in the presence of the cold cap. If true, this would argue for 
a thicker cold cap in order for it be effective.

A further complication in the interpretation of the results is caused by entrainment of particulate as material is fed into the melt. Thus the total carryover load is a combination of volatilized and entrained material. Some of the data follow the expected trend for volatilization such as cesium and chromium. The data for cesium for the open and cold cap melts are shown below in Figure 6.3. The trend of the data clearly shows the expected volatilization rate vs. temperature relationship and also a reduction in the volatilization rate for the cold cap data. The data for chromium are very similar showing a marked reduction in volatility for the cold cap case. Only data with averaged temperatures have been plotted since the uncertainty in the single temperature measurements is too great for the data to be of any value. The data for cadmium in Figure 6.4 show the opposite trends than that for cesium. Correlation with higher volatilization rates to higher temperatures is weak, and the volatilization rates for the cold cap melt are higher. Figures 6.5 and 6.6 show data for cerium and samarium. The cerium data show no difference between open melt and cold cap conditions. Below $1800^{\circ} \mathrm{C}$, the plot shows no temperature dependence for the volatilization rates. Volatilization rates for samarium shown in Figure 6.6 are higher for the cold cap case than for the open melt case. Results for gadolinium and neodymium are similar.

The results for the surrogates seem to indicate that entrainment is the primary mode of transport for them. As material is dropped into the melter chamber, fine particulate becomes airborne and can be carried away in the off-gas stream. The argument that the transport rates for the surrogates are mostly due to entrainment rather than volatilization is easy to make. First of all, the transport rates are very small. Since these elements are less than $1 \mathrm{wt} \%$ of the feed makeup, a substantial amount of entrainment would have to occur for them to be higher. The entrainment mechanism is completely independent of melt temperature, and this fact is indicated by the data for the surrogates. Entrainment may be affected by feed, however, with higher feed rates producing more entrainment. The data for the surrogates would seem to support this idea since most of the time the rates are slightly higher in the cold-cap cases where the feed rates were higher. 
Table 6.17 Volatilization rates for the HVPMs in open melt conditions.

\begin{tabular}{|c|c|c|c|c|c|c|}
\hline $\begin{array}{l}\text { Experiment } \\
\text { name/date }\end{array}$ & $\begin{array}{l}\text { Average } \\
\text { slag } \\
\text { temp } \\
(\mathrm{C})\end{array}$ & $\begin{array}{c}\mathrm{Cd} \\
{[\mathrm{mg} / \mathrm{hr}]}\end{array}$ & $\begin{array}{c}\mathrm{Cs} \\
{[\mathrm{mg} / \mathrm{hr}]}\end{array}$ & $\begin{array}{c}\mathrm{Cr} \\
{[\mathrm{mg} / \mathrm{hr}]}\end{array}$ & $\begin{array}{c}\mathrm{Pb} \\
{[\mathrm{mg} / \mathrm{hr}]}\end{array}$ & $\begin{array}{c}\mathrm{Zn} \\
{[\mathrm{mg} / \mathrm{hr}]}\end{array}$ \\
\hline $\begin{array}{c}\text { HVPM02 } \\
\text { 06/23/93 }\end{array}$ & $(1650)^{*}$ & 474 & 82 & 1.63 & 680 & 496 \\
\hline $\begin{array}{c}\text { HVPM03 } \\
\text { 06/24/93 }\end{array}$ & $(1900)^{*}$ & 396 & 65 & 1.99 & 417 & 513 \\
\hline $\begin{array}{c}\text { HVPM05 } \\
\text { 07/01/93 }\end{array}$ & 1570 & 333 & 62 & 4.31 & 357 & 287 \\
\hline $\begin{array}{c}\text { HVPM06 } \\
\text { 07/02/93 }\end{array}$ & 1730 & 281 & 135 & 16.8 & 221 & 461 \\
\hline $\begin{array}{c}\text { HVPM06 } \\
\text { 07/02/93 }\end{array}$ & 1440 & 318 & 20 & 14.8 & 43 & 53 \\
\hline
\end{tabular}

Table 6.18 Volatilization rates for the surrogates in open melt conditions.

\begin{tabular}{|c|c|c|c|c|c|}
\hline $\begin{array}{l}\text { Experiment } \\
\text { name/date }\end{array}$ & $\begin{array}{l}\text { Average } \\
\text { slag } \\
\text { temp } \\
{[\mathrm{C}]}\end{array}$ & $\begin{array}{c}\mathrm{Ce} \\
{[\mathrm{mg} / \mathrm{hr}]}\end{array}$ & $\begin{array}{c}\mathrm{Gd} \\
{[\mathrm{mg} / \mathrm{hr}]}\end{array}$ & $\begin{array}{c}\mathrm{Nd} \\
{[\mathrm{mg} / \mathrm{hr}]}\end{array}$ & $\begin{array}{c}\mathrm{Sm} \\
{[\mathrm{mg} / \mathrm{hr}]}\end{array}$ \\
\hline $\begin{array}{c}\text { HVPM02 } \\
\text { 06/23/93 }\end{array}$ & $(1650)^{*}$ & 3.12 & 5.05 & 4.62 & 3.49 \\
\hline $\begin{array}{c}\text { HVPM03 } \\
\text { 06/24/93 }\end{array}$ & $(1900)^{*}$ & 5.02 & 9.44 & 10.8 & 6.67 \\
\hline $\begin{array}{c}\text { HVPM05 } \\
\text { 07/01/93 }\end{array}$ & 1570 & 2.02 & 2.75 & 2.79 & 2.56 \\
\hline $\begin{array}{c}\text { HVPM06 } \\
\text { 07/02/93 }\end{array}$ & 1730 & 1.92 & 2.52 & 2.44 & 2.41 \\
\hline $\begin{array}{c}\text { HVPM06 } \\
\text { 07/02/93 }\end{array}$ & 1440 & 0.833 & 0.833 & 0.833 & 0.833 \\
\hline
\end{tabular}

* - single measurement 
Table 6.19 Volatilization rates for the HVPM's under cold cap conditions.

\begin{tabular}{|c|c|c|c|c|c|c|}
\hline $\begin{array}{c}\text { Experiment } \\
\text { name/date }\end{array}$ & $\begin{array}{c}\text { Average } \\
\text { slag } \\
\text { temp } \\
{[\mathrm{C}]}\end{array}$ & $\begin{array}{c}\mathrm{Cd} \\
{[\mathrm{mg} / \mathrm{hr}]}\end{array}$ & $\begin{array}{c}\mathrm{Cs} \\
{[\mathrm{mg} / \mathrm{hr}]}\end{array}$ & $\begin{array}{c}\mathrm{Cr} \\
{[\mathrm{mg} / \mathrm{hr}]}\end{array}$ & $\begin{array}{c}\mathrm{Pb} \\
{[\mathrm{mg} / \mathrm{hr}]}\end{array}$ & $\begin{array}{c}\mathrm{Zn} \\
{[\mathrm{mg} / \mathrm{hr}]}\end{array}$ \\
\hline $\begin{array}{c}\mathrm{CC} 01 \\
07 / 09 / 93\end{array}$ & $(2300)^{*}$ & 2700 & 113 & 1.14 & 2230 & 1330 \\
\hline $\begin{array}{c}\mathrm{CC} 02 \\
07 / 13 / 93\end{array}$ & 1340 & 556 & 3.33 & 0.34 & 7.98 & 73 \\
\hline $\begin{array}{c}\mathrm{CC} 03 \\
07 / 14 / 93\end{array}$ & 1870 & 1390 & 20.6 & 0.63 & 705 & 263 \\
\hline $\begin{array}{c}\mathrm{CC} 05 \\
07 / 16 / 93\end{array}$ & 2000 & 1130 & 46.8 & 0.357 & 101 & 126 \\
\hline
\end{tabular}

Table 6.20 Volatilization rates for the surrogates under cold cap conditions.

\begin{tabular}{|c|c|c|c|c|c|}
\hline $\begin{array}{l}\text { Experiment } \\
\text { Name/ } \\
\text { Date }\end{array}$ & $\begin{array}{l}\text { Average } \\
\text { Slag } \\
{[\mathrm{C}]}\end{array}$ & $\begin{array}{c}\mathrm{Ce} \\
{[\mathrm{mg} / \mathrm{hr}]}\end{array}$ & $\begin{array}{c}\mathrm{Gd} \\
{[\mathrm{mg} / \mathrm{hr}]}\end{array}$ & $\begin{array}{c}\mathrm{Nd} \\
{[\mathrm{mg} / \mathrm{hr}]}\end{array}$ & $\begin{array}{c}\mathrm{Sm} \\
{[\mathrm{mg} / \mathrm{hr}]}\end{array}$ \\
\hline $\begin{array}{c}\mathrm{CC} 01 \\
07 / 09 / 93\end{array}$ & $(2300)^{*}$ & 2.88 & 45.5 & 43.6 & 42.1 \\
\hline $\begin{array}{c}\mathrm{CC} 02 \\
07 / 13 / 93\end{array}$ & 1340 & 2.17 & 7.09 & 4.96 & 6.27 \\
\hline $\begin{array}{c}\mathrm{CC} 03 \\
07 / 14 / 93\end{array}$ & 1870 & 1.29 & 12.6 & 13.9 & 10.8 \\
\hline $\begin{array}{c}\mathrm{CC} 05 \\
07 / 16 / 93\end{array}$ & 2000 & 4.23 & 67.4 & 81.4 & 65.2 \\
\hline
\end{tabular}

* - single measurement 


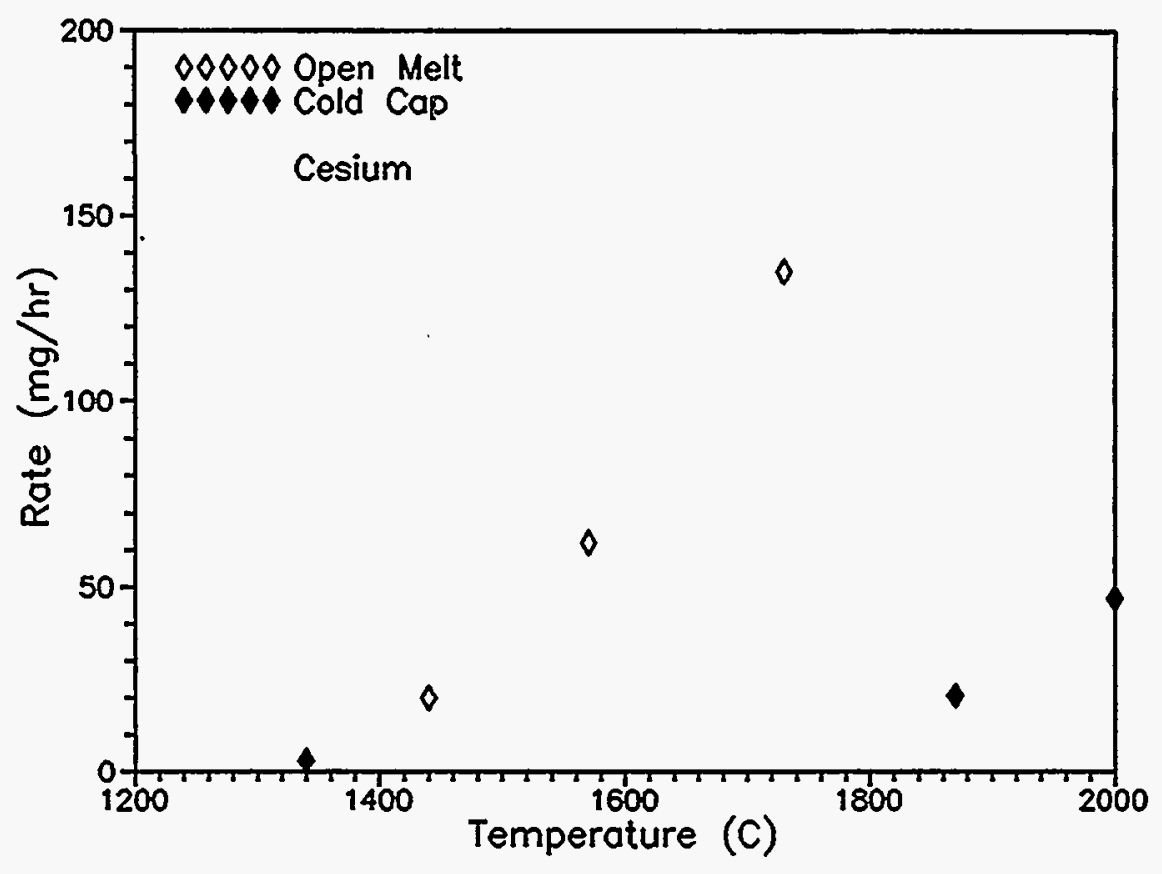

Figure 6.3 Open melt vs. cold cap cesium volatilization rates.

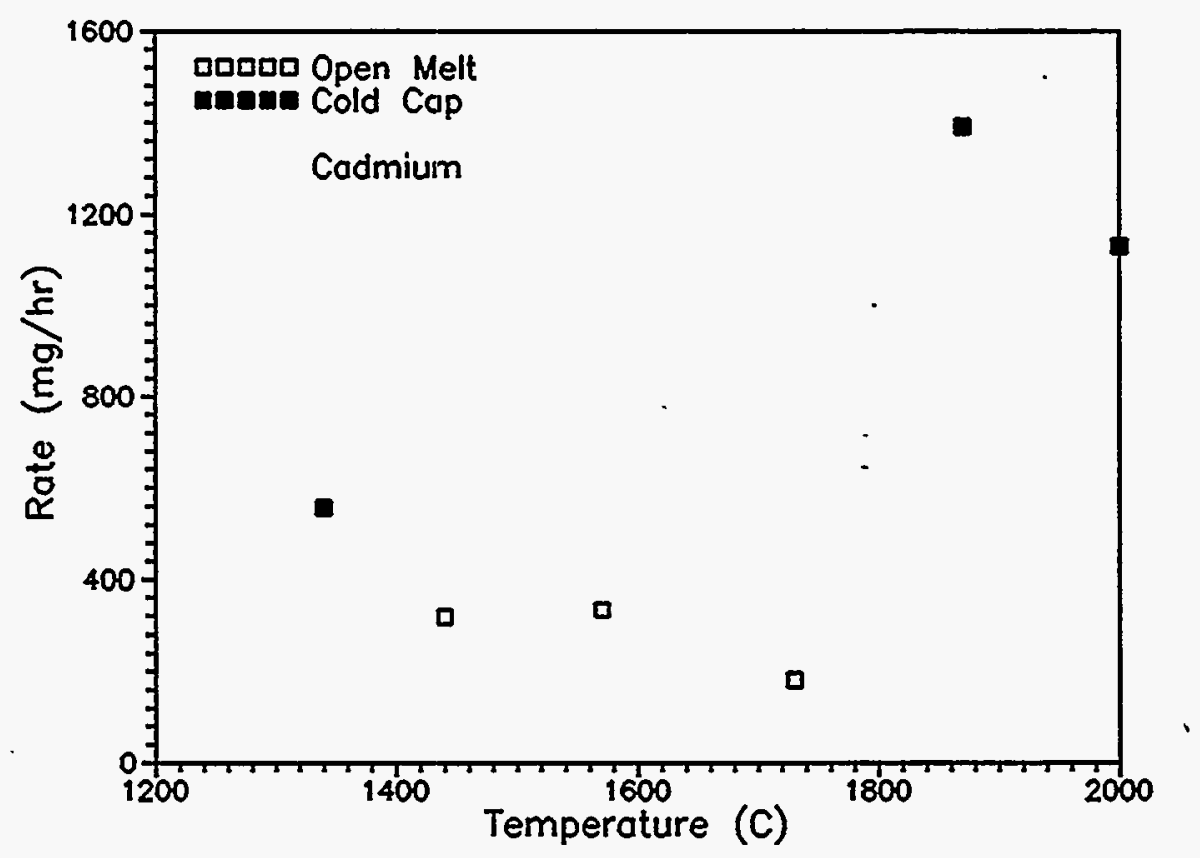

Figure 6.4 Open melt vs. cold cap cadmium volatilization rates. 


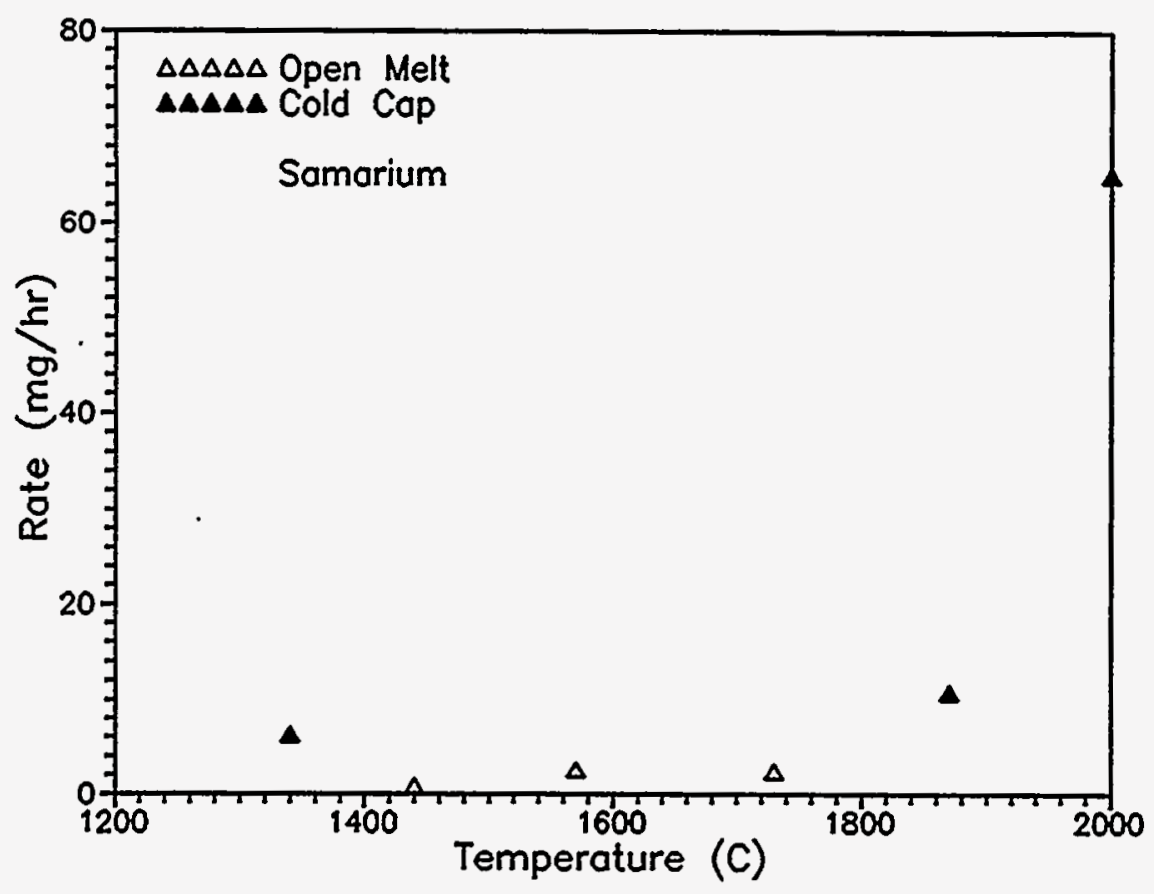

Figure 6.5 Open melt vs. cold cap cerium volatilization rates.

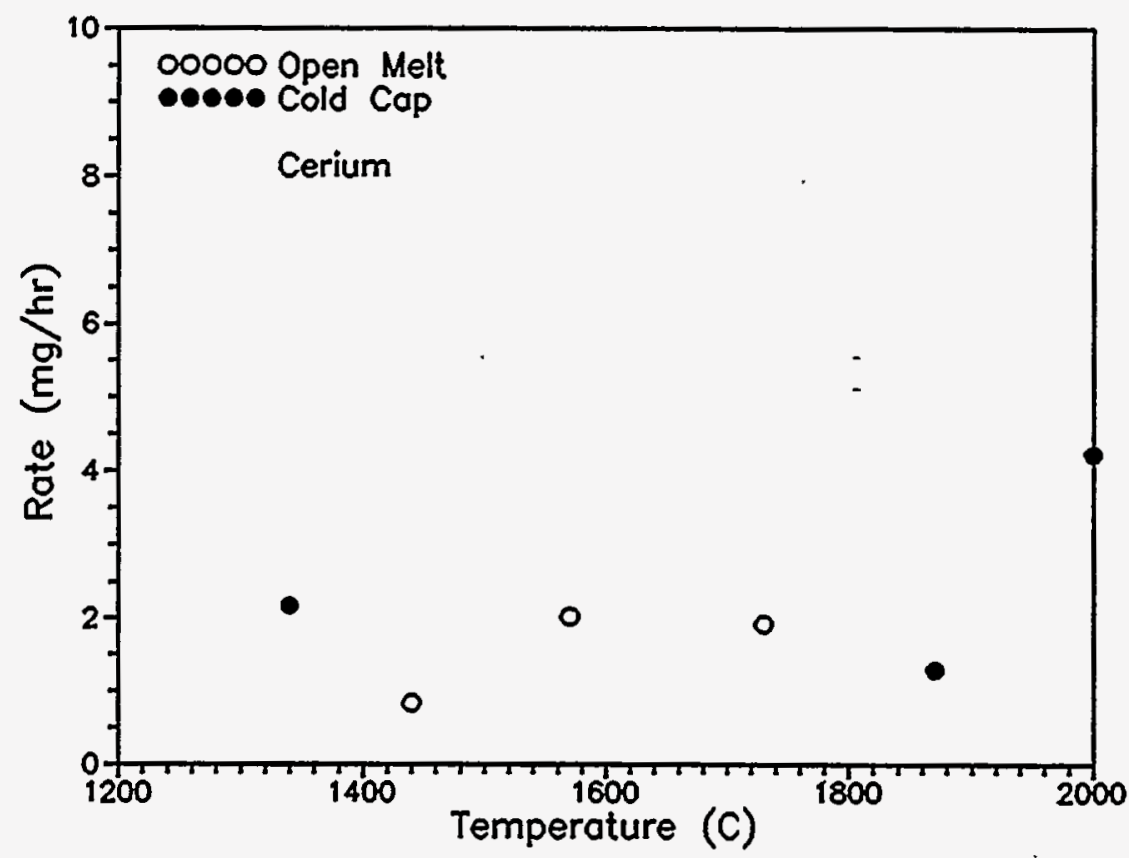

Figure 6.6 Open melt vs. cold cap samarium volatilization rates. 


\section{REDOX MEASUREMENTS (FY-93)}

\subsection{Introduction}

The redox experiments tested the extremes in reducing or oxidizing conditions and their effect on melt chemistry and crystallization. Two melts had different levels of carbon blended into the melt mix to achieve two reducing conditions. Alternately, two additional melts were subjected to two levels of oxidation by injecting air under the melt surface with a lance. In the reducing cases, the first melt mix contained sufficient carbon to reduce half of the iron oxides to $\mathrm{Fe}$, while the second melt contained twice as much carbon to convert all of the iron oxides to $\mathrm{Fe}$. In the oxidizing experiments, which employed an air lance, sufficient air was injected into one melt to oxidize half of the iron (assuming $\mathrm{FeO}$ ) to $\mathrm{Fe}_{2} \mathrm{O}_{3}$, while twice as much air was introduced into the next melt to convert all of the $\mathrm{FeO}$ to $\mathrm{Fe}_{2} \mathrm{O}_{3}$. The general operating conditions of each of the redox tests are summarized in Table 7.1.

In order to determine the effects of varying redox conditions on the distribution of high vapor pressure metals $(\mathrm{Cd}, \mathrm{Cr}, \mathrm{Pb}$, and $\mathrm{Zn}$ ), $1.0 \mathrm{wt} \%$ (metals basis) of each of these elements was added to the mix as oxides. So that zirconolite crystals would form, $4.0 \mathrm{wt} \% \mathrm{TiO}_{2}$ and $2 \mathrm{wt} \%$ $\mathrm{ZrO}_{2}$ were added to the mix. The $\mathrm{CaO}$ already present $(10 \mathrm{wt} \%$ for $\mathrm{A}-40)$ was considered sufficient to enable zirconolite formation. Also, $1.0 \mathrm{wt} \%$ each of $\mathrm{CeO}_{2}$ and $\mathrm{Sm}_{2} \mathrm{O}_{3}$ was added as surrogates for actinide elements so that the zirconolite, if formed, could demonstrate its ability to remove these surrogates from the glass phase and incorporate them into its structure. In addition, $1.0 \mathrm{wt} \%$ of $\mathrm{Cs}_{2} \mathrm{CO}_{3}$ was added to each of the melts, and in the case of the oxidizing melts only, $1.0 \mathrm{wt} \%$ each of $\mathrm{Nd}_{2} \mathrm{O}_{3}$ and $\mathrm{Gd}_{2} \mathrm{O}_{3}$ was added as actinide surrogates also.

An air lance was designed and fabricated to provide submerged air/oxygen injection into the slag. The air lance was constructed from three concentric stainless steel tubes. As shown in Figure 7.1, the inner and outer tubes were welded to a copper end piece, while the intermediate tube provides a flow path for the cooling water. Air is supplied to the inner tube that delivers gas to the copper nozzle. The copper nozzle contains five 0.025 -inch diameter holes, four being directed at 30 degrees from center and one on center as shown in the diagram. Air flow into the lance is monitored by a MKS M062-LS06E mass flow valve and a MKS 440 series mass flow controller. During operation the lance is earth grounded through the power supply for safety. 
Table 7.1 Summary of FY-93 redox tests.

\begin{tabular}{|c|c|c|c|c|c|c|}
\hline $\begin{array}{l}\text { Test } \\
\text { name }\end{array}$ & Date & $\begin{array}{l}\text { Starting } \\
\text { material }\end{array}$ & $\begin{array}{l}\text { Run } \\
\text { time } \\
\text { (min) }\end{array}$ & $\begin{array}{l}\text { Ave slag } \\
\text { temp } \\
\text { (C) }\end{array}$ & $\begin{array}{c}\text { Ave } \\
\text { power } \\
(\mathrm{kW})\end{array}$ & $\begin{array}{l}\text { Shutdown } \\
\text { condition }\end{array}$ \\
\hline RED01 & $7 / 22$ & $\begin{array}{l}6.0 \mathrm{~kg} \text { IEB } 4 / \mathrm{A}-40 \\
+ \text { HVPMs } \\
+ \text { surrogates }\end{array}$ & 110 & 1470 & 10.9 & Normal \\
\hline RED02 & $7 / 27$ & $\begin{array}{l}6.0 \mathrm{~kg} \text { IEB } 4 / \mathrm{A}-40 \\
+ \text { HVPMs } \\
+ \text { surrogates }\end{array}$ & 95 & 1570 & 11.5 & Normal \\
\hline OX01 & $6 / 23$ & $\begin{array}{l}6.0 \mathrm{~kg} \text { IEB } 4 / \mathrm{A}-40 \\
+ \text { HVPMs } \\
+ \text { surrogates }\end{array}$ & 115 & 1615 & 6.6 & Normal \\
\hline OX02 & $6 / 24$ & $\begin{array}{l}\text { OX01 remelt } \\
+3.0 \mathrm{~kg} \mathrm{IEB} 4 / \mathrm{A}-40\end{array}$ & 125 & 1710 & 12.8 & Normal \\
\hline OX03A & $6 / 25$ & $\begin{array}{l}6.0 \mathrm{~kg} \mathrm{IEB} 4 / \mathrm{A}-40 \\
+ \text { HVPMs } \\
+ \text { surrogates } \\
+3.0 \mathrm{~kg} \text { IEB } 4 / \mathrm{A}-40\end{array}$ & 95 & 1700 & 13.0 & $\begin{array}{l}\text { Positive } \\
\text { pressure } \\
\text { buildup }\end{array}$ \\
\hline OX03B & $7 / 01$ & OX03A remelt & 120 & 1700 & 13.0 & $\begin{array}{l}\text { Normal } \\
\text { (anode } \\
\text { consumed) }\end{array}$ \\
\hline
\end{tabular}

\subsection{Experimental Conditions}

The redox experiments were conducted in the modified bench-scale arc melter. The RED01 test used an addition of 75 grams of carbon to produce a half stoichiometric reduction of the iron assuming $\mathrm{FeO}(\mathrm{FeO}+\mathrm{C} \Leftrightarrow \mathrm{Fe}+\mathrm{CO})$. The test was carried out for almost 2 hours, trying to maintain about $1500^{\circ} \mathrm{C}$ in the slag. The test was characterized by a long period of dust evolution. Visual observations indicated that direct combustion of the carbon powder may have been taking place. The slag from this experiment was slightly orange in color. Metal beads were found at the bottom of the slag. 


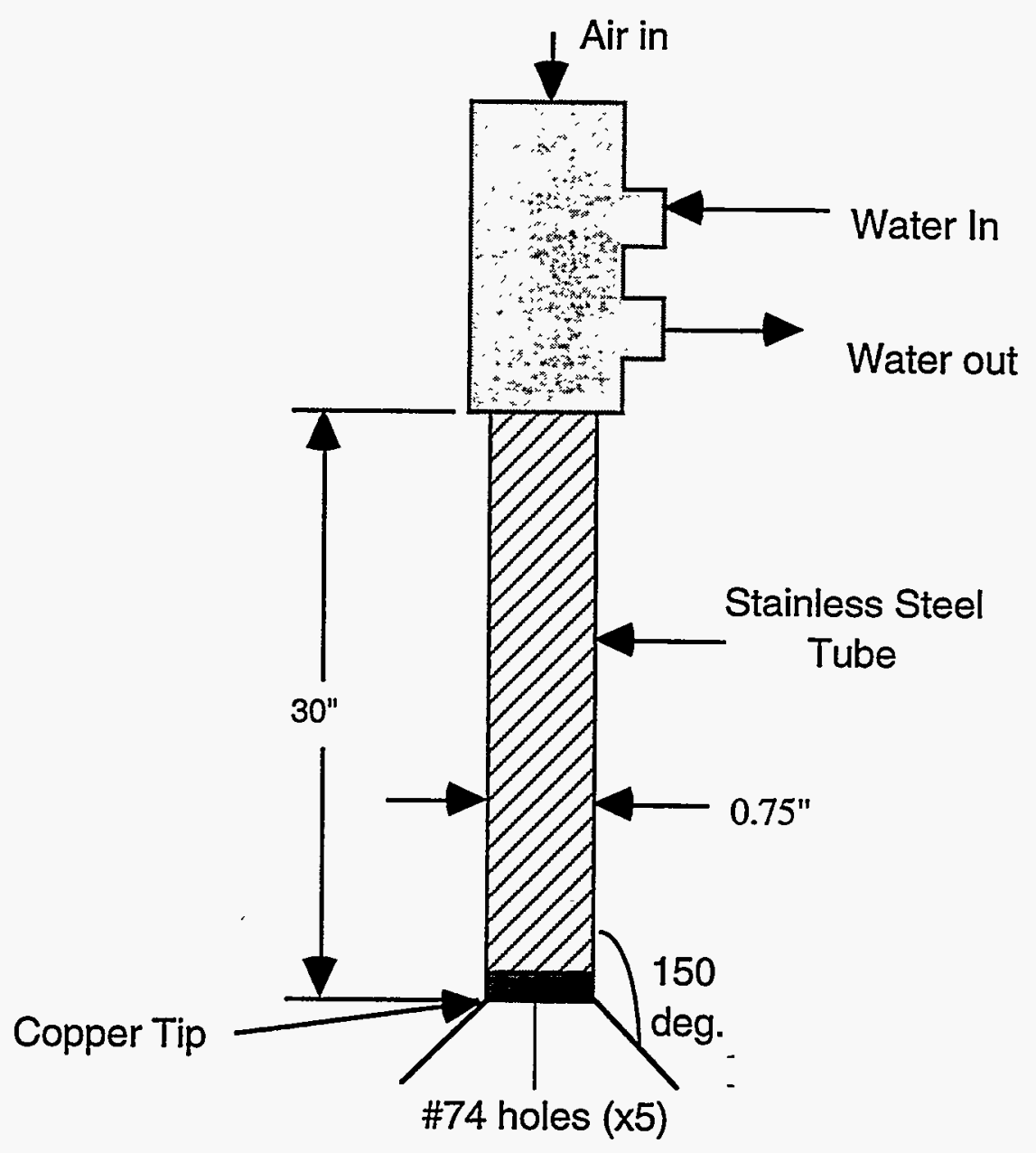

Figure 7.1 Schematic of the air/oxygen lance. 
The RED02 test used an addition of 318 grams of carbon, twice the stoichiometric amount to reduce all the iron from the melt. The test was carried out for about one and one-half hours trying to maintain about $1500^{\circ} \mathrm{C}$ in the slag. Again, direct combustion of some of the carbon with the normal air flow through the melter appeared to be taking place. The slag from this experiment was black in color and, again, metal beads were formed in the slag at bottom of the crucible.

Forty minutes after starting the OX01 test when the mixture was completely melted, the air lance with air flow of $2.5 \mathrm{slpm}$ was inserted in the molten slag. The lance was inserted for 70 minutes to provide enough oxygen to convert half the iron oxides (assuming all of it is $\mathrm{FeO}$ ) into $\mathrm{Fe}_{2} \mathrm{O}_{3}\left(2 \mathrm{FeO}+1 / 2 \mathrm{O}_{2} \Leftrightarrow \mathrm{Fe}_{2} \mathrm{O}_{3}\right)$. It was found after the run that the level of slag was too low for proper mixing of air with the slag (part of the slag froze off), and the portion of the mix directly under the lance did not melt. It was decided to run this experiment again with more material in the crucible so the lance would meet the slag directly between the electrodes.

The OX02 test started with $3.0 \mathrm{~kg}$ more of the IEB-4/A-40 mix added to the OX01 crucible liner. This was intended to raise the slag level so the air-lance would intercept the slag surface directly between the electrodes for maximum mixing. After 50 minutes the mix was melted and the air lance was inserted in the molten slag with air flowing through it at $5.0 \mathrm{slpm}$. The lance was inserted for 55 minutes $\left(2 \mathrm{FeO}+1 / 2 \mathrm{O}_{2} \Leftrightarrow \mathrm{Fe}_{2} \mathrm{O}_{3}\right.$ - half stoichiometry). As soon as the lance was inserted, melt began to bubble around the area of the lance insertion point. The experiment continued without incident and was shutdown by removing the air lance and turning off the power supplies. After cooling and removal from the crucible, the slag was observed to be a light brown color throughout.

The OX03A test started with $6.0 \mathrm{~kg}$ IEB-4/A-40 (including HVPMs and TRU/U surrogates). After 40 minutes when it was melted, an additional $3.0 \mathrm{~kg}$ of IEB-4/A-40 mix with HVPM and TRU/U surrogates were added using the auger feeder, raising the slag level so the air lance would intercept the slag surface directly between the electrodes for maximum mixing. After feeding and melting for another 35 minutes, the air lance was inserted in the molten slag with air flowing through it at $10.0 \mathrm{slpm}$. The lance was intended to be inserted for 55 minutes to allow for full stoichiometric oxidation of iron oxides $\left(2 \mathrm{FeO}+1 / 2 \mathrm{O}_{2} \Leftrightarrow \mathrm{Fe}_{2} \mathrm{O}_{3}\right)$. As soon as the lance was inserted, melt began to bubble around the area of the lance insertion point. After operating for another 15 minutes, the system pressure measured positive. Attempts were made to lower the pressure but failed, and the system was shut down. 
The OX03B test remelted the OX03A material in the same refractory crucible liner. Because of the porous nature of the previously melted slag, a large hole quickly developed under the cathode shortly after startup, and the arc extinguished due to over voltage. The system was opened and material moved around and leveled in order to restart the run. Another graphite strip was placed under the electrode, the system sealed up and restarted without consequence. The melter was operated for another 40 minutes before the air lance was inserted in the molten slag with air flowing through it at $10 \mathrm{slpm}$. An additional 40 minutes was needed to achieve the total oxidation of $9 \mathrm{kgs}$ of material based on full stoichiometry. As the lance was inserted, the melt began to boil around the insertion point. After operating for another 40 minutes, the system was shut down.

\subsection{Analytical Results}

\subsection{1 $\mathrm{Fe}^{+2} / \mathrm{Fe}^{+3}$ Ratios}

The $\mathrm{Fe}^{+2} / \mathrm{Fe}^{+3}$ ratio (or $\mathrm{FeO} / \mathrm{Fe}_{2} \mathrm{O}_{3}$ ratio) is a convenient measure of the redox state of the melt. Influencing the $\mathrm{Fe}^{+2} / \mathrm{Fe}^{+3}$ ratio will affect development of several of the crystalline species during melt cooldown. For example, the transition from a Fe${ }^{+2}$ to $\mathrm{Fe}^{+3}$ dominant material may inhibit formation of augite $\left[\mathrm{Ca}\left(\mathrm{MgFe}^{+2} \mathrm{Al}\right)(\mathrm{SiAl})_{2} \mathrm{O}_{6}\right]$ and favor formation of pseudobrookite $\left(\mathrm{Fe}_{2} \mathrm{TiO}_{5}\right)$ instead of ilmenite $\left(\mathrm{FeTiO}_{3}\right)$. One question needing resolution is whether the redox state of the melt will affect development of zirconolite $\left(\mathrm{CaZrTi}{ }_{2} \mathrm{O}_{7}\right)$, spinels (usually $\left.\mathrm{Fe}_{3} \mathrm{O}_{4}\right)$, or other desired phases. Zirconolite development is largely a function of the concentrations of $\mathrm{TiO}_{2}$, $\mathrm{ZrO}_{2}$, and $\mathrm{CaO}$ in the residual glass. The formation of zirconolite may be influenced indirectly by the redox state of the melt. If an oxidized melt is rich in iron, it will produce pseudobrookite early in the cooling cycle. This phase will consume $\mathrm{TiO}_{2}$ and may deplete this oxide from the residual glass to the extent that zirconolite cannot precipitate. ${ }^{8}$.

Slag samples from each of the redox tests were analyzed by an independent laboratory for total iron oxide content and $\mathrm{FeO}$ content. Total iron oxide content was determined by ICP analysis and $\mathrm{FeO}$ content by titration. Table 7.2 shows these results along with the calculated $\mathrm{Fe}^{+2} / \mathrm{Fe}^{+3}$ and $\mathrm{Fe}^{+3} / \mathrm{Fe}_{\text {tot }}$ ratios. For comparison, two separate IEB $4 / \mathrm{A}-40$ samples made for another project and produced under "normal" arc melter operating conditions are also shown. The operating state of the arc melter is slightly reducing, due to the presence of the carbon electrodes.

The $\mathrm{Fe}^{+2} / \mathrm{Fe}^{+3}$ ratios follow the redox conditions imposed on the melts except for the highly reducing and highly oxidizing cases. For instance, when half the carbon needed to 
Table 7.2 Redox results over a range of reducing and oxidizing conditions.

\begin{tabular}{|l|c|c|c|c|c|}
\hline \multicolumn{1}{|c|}{ Test } & $\begin{array}{c}\text { Operating } \\
\text { condition }\end{array}$ & $\begin{array}{c}\text { Total } \\
\text { iron oxide } \\
\text { (wt\%) }\end{array}$ & $\begin{array}{c}\mathrm{FeO} \\
(\mathrm{wt} \%)\end{array}$ & $\begin{array}{c}\mathrm{Fe}^{+2} / \mathrm{Fe}^{+3} \\
\text { ratio }\end{array}$ & $\begin{array}{c}\mathrm{Fe}^{+2} / \mathrm{Fe}^{\text {tot }} \\
\text { ratio }\end{array}$ \\
\hline RED02 & highly reducing & 14.2 & 11.9 & 13.60 & 0.93 \\
\hline RED01 & slightly reducing & 12.0 & 10.9 & infinite & 1.00 \\
\hline PSPI03C & normal & 16.9 & 14.5 & 20.49 & 0.95 \\
\hline PSPI03 & normal & 16.1 & 12.3 & 5.87 & 0.85 \\
\hline OX02 & slightly oxidizing & 17.5 & 8.07 & 1.05 & 0.51 \\
\hline OX03B & highly oxidizing & 16.4 & 12.8 & 6.55 & 0.87 \\
\hline
\end{tabular}

effect reduction was blended with the mix, the $\mathrm{Fe}^{+3}$ was eliminated from the specimen examined. Therefore, with only $\mathrm{Fe}^{+2}$ present the $\mathrm{Fe}^{+2} / \mathrm{Fe}^{+3}$ ratio was infinite. The range of the $\mathrm{Fe}^{+2} / \mathrm{Fe}^{+3}$ ratio is infinity for complete reduction and zero for complete oxidation. In the other reducing case, when twice the needed carbon was present in the melt, not all of the $\mathrm{Fe}^{+3}$ was reduced in the specimen and the $\mathrm{Fe}^{+2} / \mathrm{Fe}^{+3}$ ratio was 13.6:1. When the air lance was inserted into the melts, the most $\mathrm{Fe}^{+3}$ was produced when the lesser amount of air was injected (ratio $=1.05$ ). When enough air was injected to convert all of the $\mathrm{Fe}$ to $\mathrm{Fe}^{+3}$ the $\mathrm{Fe}^{+2} / \mathrm{Fe}^{+3}$ ratio increased to 6.55 rather decreasing toward zero. In both cases, the injected oxygen had to compete with reducing conditions normally present in the arc furnace.

Speculation from these results is that there may have been localized effects on the redox state for these melts and that the highly reduced and oxidized samples that were analyzed were not representative of the overall redox state of the melt. Alternatively, in the case of the highly oxidizing melt, it may be argued that the increased air flow rate may have caused localized cooling to occur in the injection region and that higher flow velocities might reduce the residence time of the air in the slag. If so, the outcome would be to decrease the effective oxidation rate. After removal from the furnace, the fracture surfaces of both slags subjected to air lancing exhibited a brownish color characteristic of an elevated $\mathrm{Fe}_{2} \mathrm{O}_{3}$ content. Results for the highly reducing melt remain somewhat of a mystery, except for the possibility stated above, that the redox state was not homogenous throughout the melt and caused a sampling error. 


\subsubsection{SEM/EDXS Analysis of Slag}

Examination of slag specimens by SEM, EDXS, and XRD indicated that the cooldown of the melts was too rapid to enable significant crystal growth to occur. Samples melted under reducing conditions were almost entirely glass, with a few feathery crystals of chromite spinel and numerous small beads of metallic iron present. These features may be observed in Figures 7.2 and 7.3. The corresponding chemistry data for the EDXS spots are contained in Tables 7.3 and 7.4. The elemental analysis by the EDXS has been converted to oxide forms based on the amount of oxygen detected, except where noted, as in column 2. In cases where the oxygen content cannot account for oxide forms (in these cases, only 1 or $2 \mathrm{wt} \%$ ), the major components are assumed to be metallic. The conversions are done by software on the SEM/EDXS computer.

The beads of metallic iron are considerably larger in the highly reducing case. Even larger beads (up to $6 \mathrm{~mm}$ ) settled toward the bottom of the melt and became trapped in the cooler, viscous material near the cold container liner. Spinel crystals were too small for the EDXS technique to produce a meaningful analysis. Of the additives, $\mathrm{CdO}, \mathrm{PbO}$, and $\mathrm{ZnO}$ were below the EDXS detection limit and were assumed to have evaporated almost entirely during melting, the $\mathrm{Cr}_{2} \mathrm{O}_{3}$ was combined with the spinels, while the $\mathrm{Cs}_{2} \mathrm{O}, \mathrm{TiO}_{2}, \mathrm{ZrO}_{2}$, and the surrogates remained in the glass. The $\mathrm{CdO}, \mathrm{PbO}$, and $\mathrm{ZnO}$ were found deposited on the furnace interior and in the cold trap, along with some of the other oxides lost as dust, or by evaporation or ejection from the melt.

The XRD patterns showed the spinels and the presence of pyroxene crystals, although pyroxenes could not be discerned in the photomicrographs. Some $\mathrm{Fe}_{3} \mathrm{C}$ was indicated by $\mathrm{XRD}$, confirming the reducing nature of the melts. 


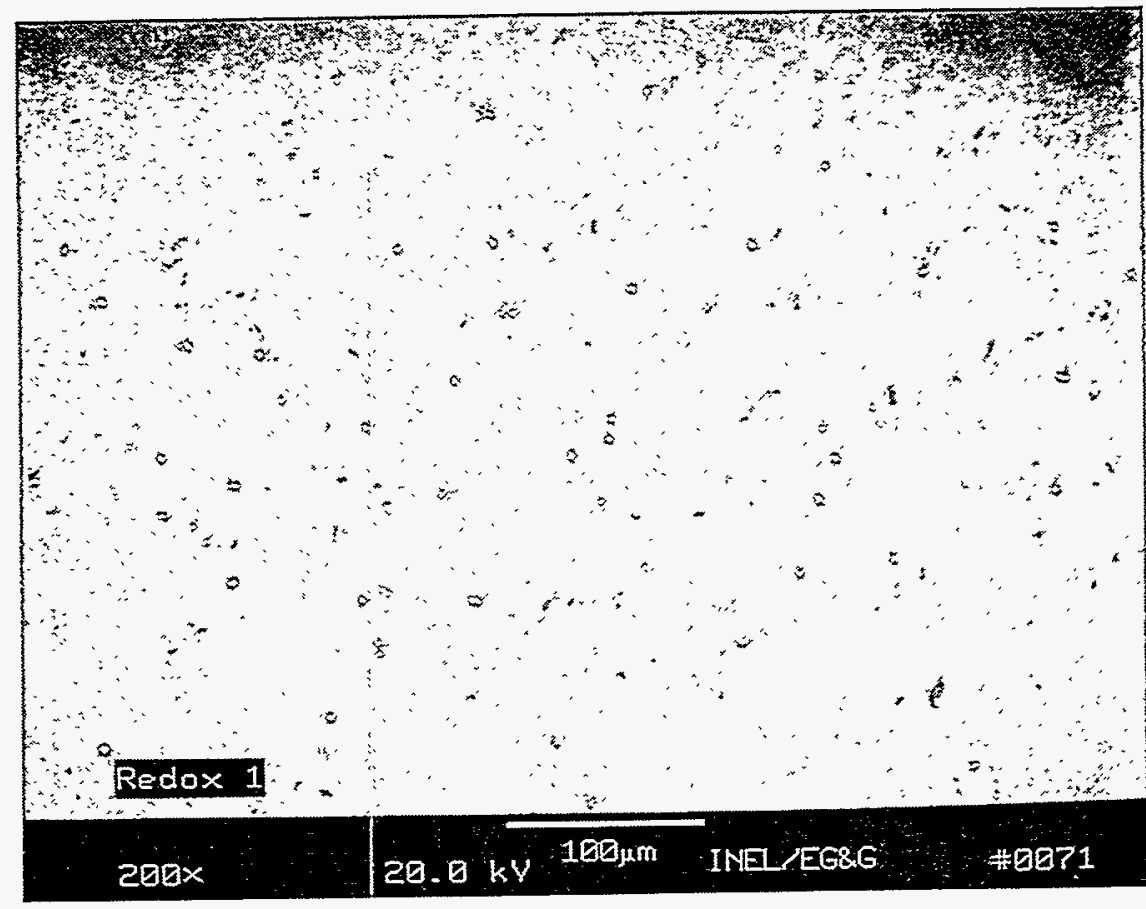

(a)

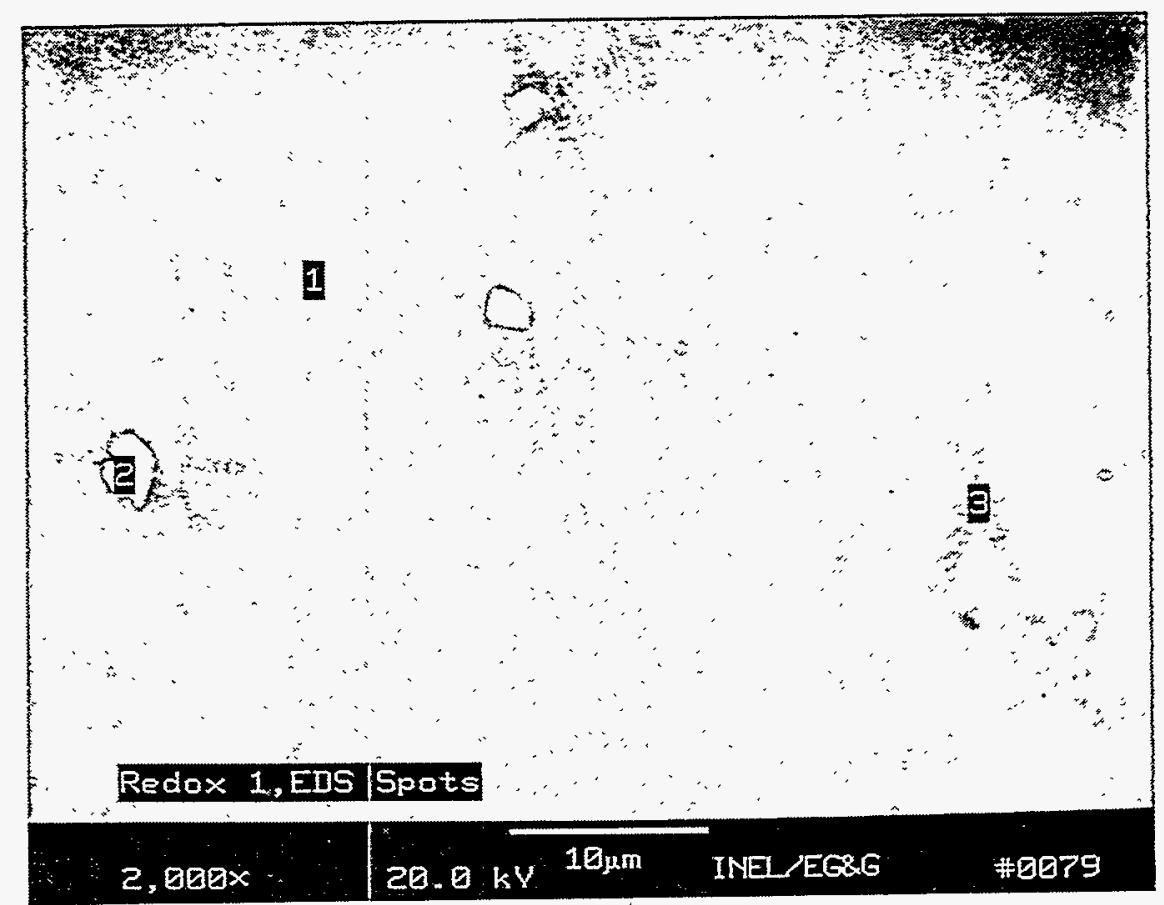

(b)

Figure 7.2 SEM micrographs for the slightly reduced slags: (a) general area and (b) associated EDXS spots. 
Table 7.3 EDXS analysis of designated spots in the slightly reduced slag (RED01).

\begin{tabular}{|c|c|c|c|c|}
\hline & Average & 1 & $2^{*}$ & 3 \\
\hline $\mathrm{Na}_{2} \mathrm{O}$ & 1.65 & 1.74 & & 1.98 \\
\hline $\mathrm{MgO}$ & 2.96 & 3.18 & & 2.66 \\
\hline $\mathrm{Al}_{2} \mathrm{O}_{3}$ & 11.33 & 11.49 & 0.81 & 11.11 \\
\hline $\mathrm{SiO}_{2}$ & 57.31 & 57.42 & 3.40 & 49.22 \\
\hline $\mathrm{K}_{2} \mathrm{O}$ & 1.92 & 1.79 & & 2.11 \\
\hline $\mathrm{CaO}$ & 6.82 & 7.28 & 0.31 & 2.70 \\
\hline $\mathrm{TiO}_{2}$ & 4.64 & 4.42 & 0.23 & 4.37 \\
\hline $\mathrm{FeO}$ & 8.93 & 8.85 & 93.14 & 10.82 \\
\hline $\mathrm{ZrO}_{2}$ & 2.18 & 2.38 & & 1.45 \\
\hline $\mathrm{CeO}_{2}$ or Ce $\mathrm{O}_{3}$ & 0.54 & 0.59 & & \\
\hline $\mathrm{Nd}_{2} \mathrm{O}_{3}$ & & & & 0.74 \\
\hline $\mathrm{Sm}_{2} \mathrm{O}_{3}$ & 0.41 & 0.44 & & \\
\hline $\mathrm{Gd}_{2} \mathrm{O}_{3}$ & & & & \\
\hline $\mathrm{Cs}_{2} \mathrm{O}$ & & 0079 & & \\
\hline $\mathrm{Cr}_{2} \mathrm{O}_{3}$ & 1.30 & 0.41 & 0.56 & \\
\hline $\mathrm{ZnO}$ & & & & \\
\hline $\mathrm{PbO}$ & & & & \\
\hline $\mathrm{CdO}^{\mathrm{Photo}}$ & 0071 & & & \\
\hline
\end{tabular}

* - metallic 


$$
0 I-L
$$

'słods SXaG pəze!cosse (q)

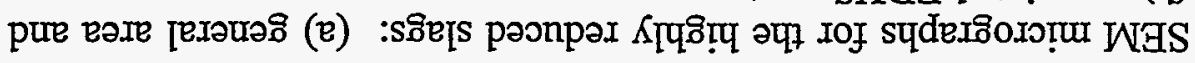

(q)

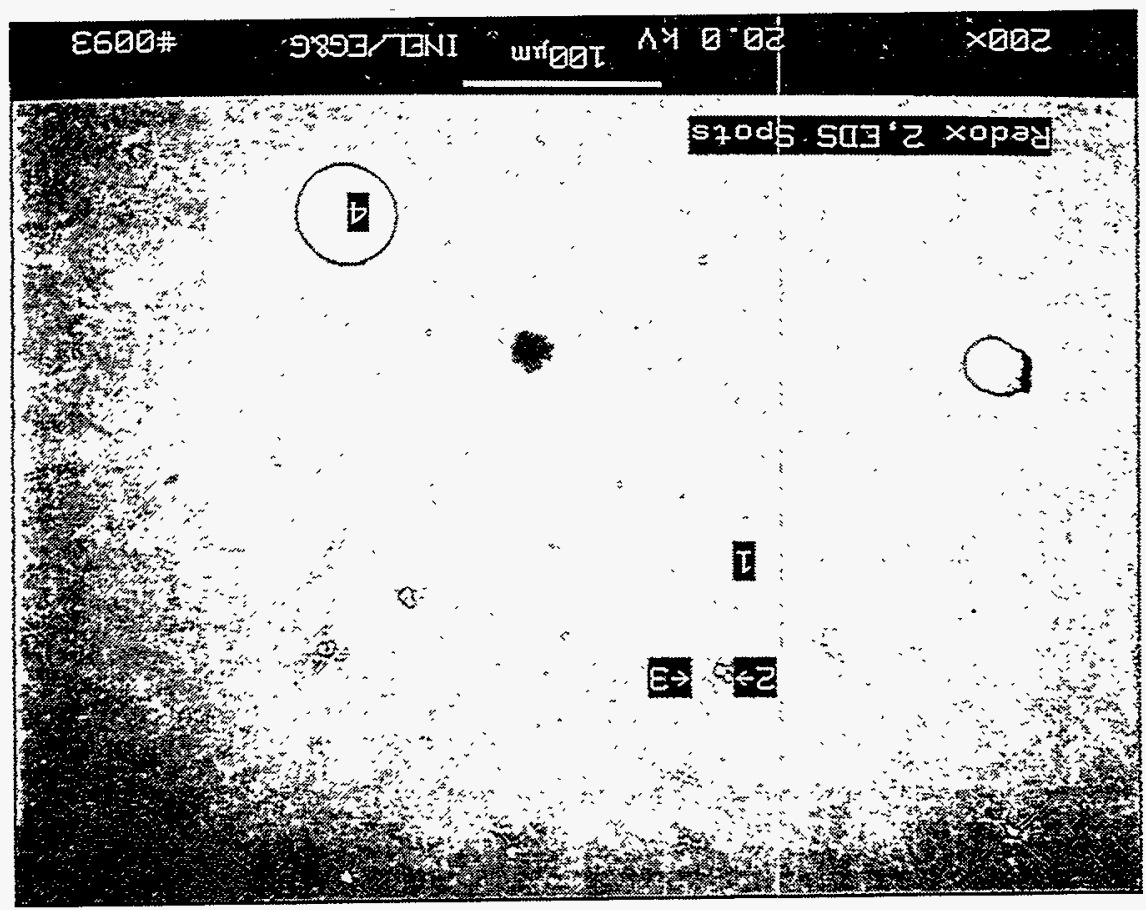

(B)

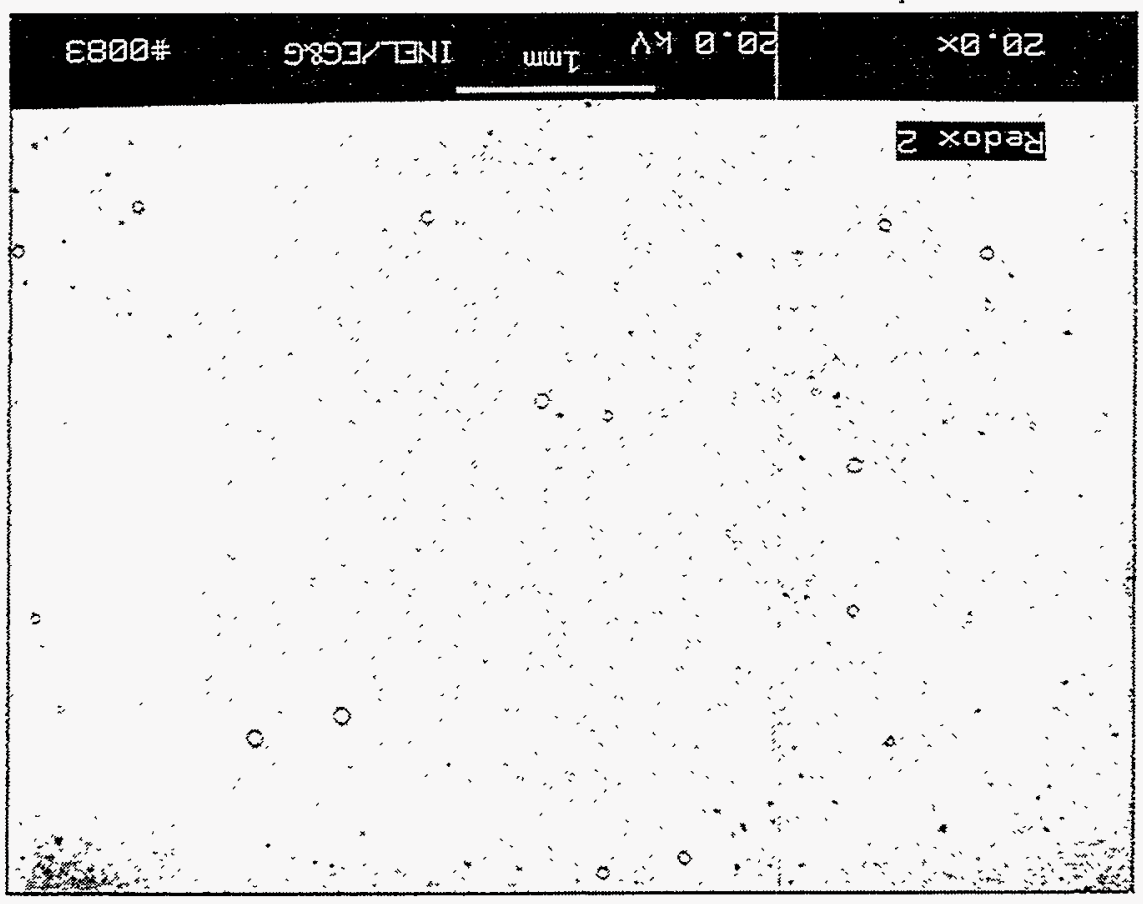




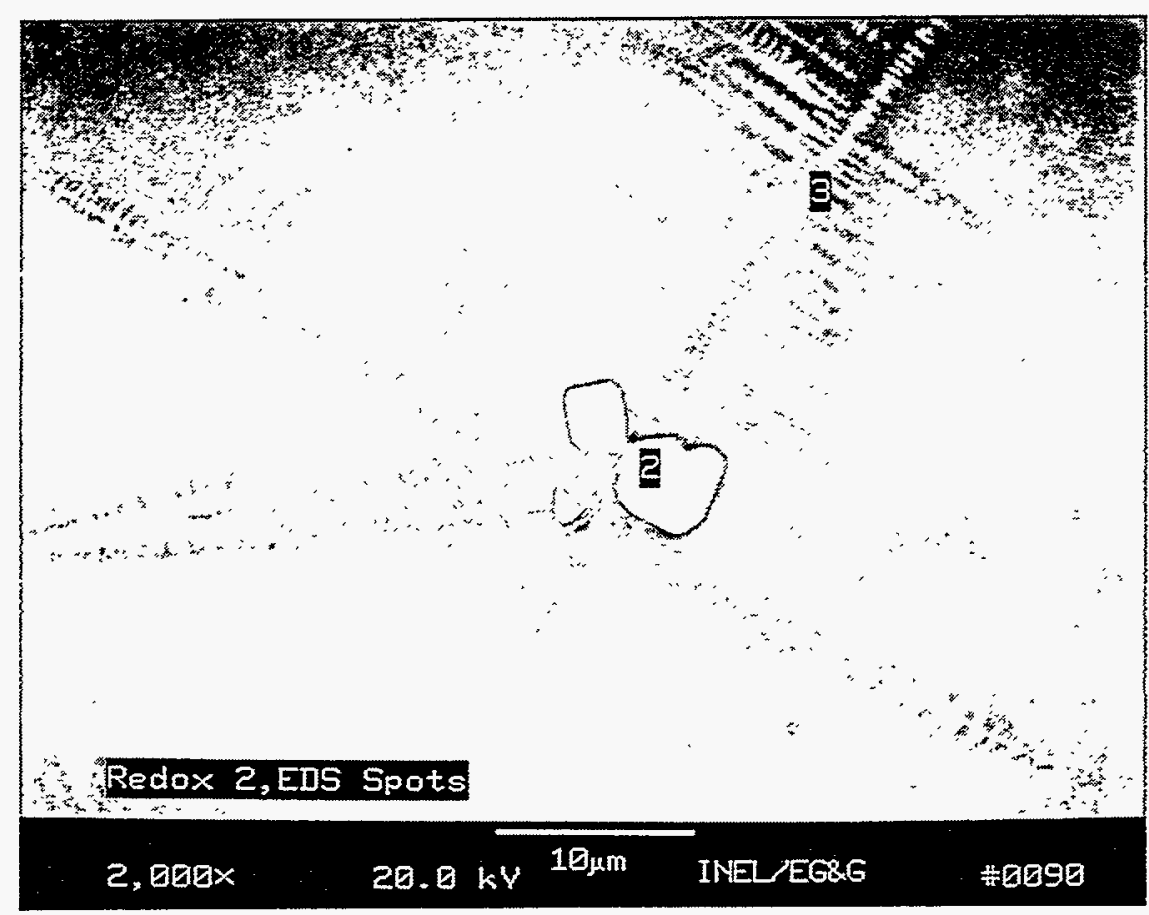

(c)

Figure 7.3 SEM micrographs for the highly reduced slags: (c) close-up of associated EDXS spots. 
Table 7.4 EDXS analysis of designated spots in the highly reduced slag (RED02).

\begin{tabular}{|c|c|c|c|c|c|}
\hline & Average & 1 & $2^{*}$ & 3 & $4^{*}$ \\
\hline $\mathrm{Na}_{2} \mathrm{O}$ & 2.51 & 1.82 & & 2.14 & \\
\hline $\mathrm{MgO}$ & 2.84 & 3.37 & & 2.76 & \\
\hline $\mathrm{Al}_{2} \mathrm{O}_{3}$ & 10.29 & 10.37 & & 9.70 & \\
\hline $\mathrm{SiO}_{2}$ & 54.87 & 55.46 & 0.59 & 44.47 & 0.43 \\
\hline $\mathrm{K}_{2} \mathrm{O}$ & 2.05 & 1.58 & & 2.24 & \\
\hline $\mathrm{CaO}$ & 7.37 & 8.51 & 0.11 & 1.77 & \\
\hline $\mathrm{TiO}_{2}$ & 5.13 & 4.91 & 0.21 & 5.69 & \\
\hline $\mathrm{FeO}$ & 10.25 & 9.59 & 98.56 & 14.09 & 97.56 \\
\hline $\mathrm{ZrO}_{2}$ & 2.62 & 2.91 & & 1.58 & 0.35 \\
\hline $\mathrm{CeO}_{2}$ or Ce $\mathrm{O}_{3}$ & 0.54 & 0.74 & & & \\
\hline $\mathrm{Nd}_{2} \mathrm{O}_{3}$ & & & & & \\
\hline $\mathrm{Sm}_{2} \mathrm{O}_{3}$ & 0.34 & 0.54 & & & \\
\hline $\mathrm{Gd}_{2} \mathrm{O}_{3}$ & & & & & \\
\hline $\mathrm{Cs}_{2} \mathrm{O}$ & & & & & \\
\hline $\mathrm{Cr}_{2} \mathrm{O}_{3}$ & 1.20 & 0.19 & 0.54 & 15.54 & \\
\hline $\mathrm{ZnO}$ & & & & & \\
\hline $\mathrm{PbO}$ & & & & & \\
\hline $\mathrm{CdO}_{\mathrm{Photo}}$ & 0083 & 0093 & 0090,0093 & 0090,0093 & \\
\hline
\end{tabular}

* - metallic 
The melts produced under oxidizing conditions appear less glassy, even though the samples were subjected to about the same cooling rate after melting was complete. The oxidized melts exhibited no metallic beads (except for some $\mathrm{Cu}$ that melted from the anode at the end of the heat) and considerably more crystallization. The SEM photomicrographs are shown in Figures 7.4 and 7.5, and the individual EDXS spot analyses are given in Tables 7.5 and 7.6. The spinel composition was about the same as before (chromite) and had grown much larger. Some of these spinels contained elevated levels of zinc. A substantial network of fine crystals is evident at higher magnifications which appear to be pyroxene, and this was confirmed by XRD to be augite $\left[\mathrm{Ca}(\mathrm{MgFeAl})(\mathrm{SiAl})_{2} \mathrm{O}_{6}\right]$ and/or omphacite $\left[\mathrm{CaNa}(\mathrm{MgFeAl})(\mathrm{SiAl})_{2} \mathrm{O}_{6}\right]$. The lacy network of pyroxene crystals (Figures 7.4e and 7.5b) obscures the amount of glass present. After prolonged (hours) exposure to an elevated temperature, or slower cooling, the pyroxene crystals would coalesce into a bulkier, tabular form, and it would appear that more glass was present. The feathery spinels behave in a similar manner. Growth of the pyroxene networks from individual nuclei continued until collision between adjacent growths occurs giving the appearance of grain boundaries. Lanthanides tend to become concentrated at these boundaries and precipitate, as is shown in Figures $7.4 \mathrm{~d}$ and $7.4 \mathrm{c}$. No crystals approximately conforming to the zirconolite composition could be located. Cesium was below the detection limit in the area analysis but could be found in the residual glass, and much of it was presumed to have left the melt. A large zirconia-rich area was found (Figures $7.5 \mathrm{a}$ and $7.5 \mathrm{~d}$ ). It was believed to result from a zircon grain from the crucible liner decomposed in the melt. 


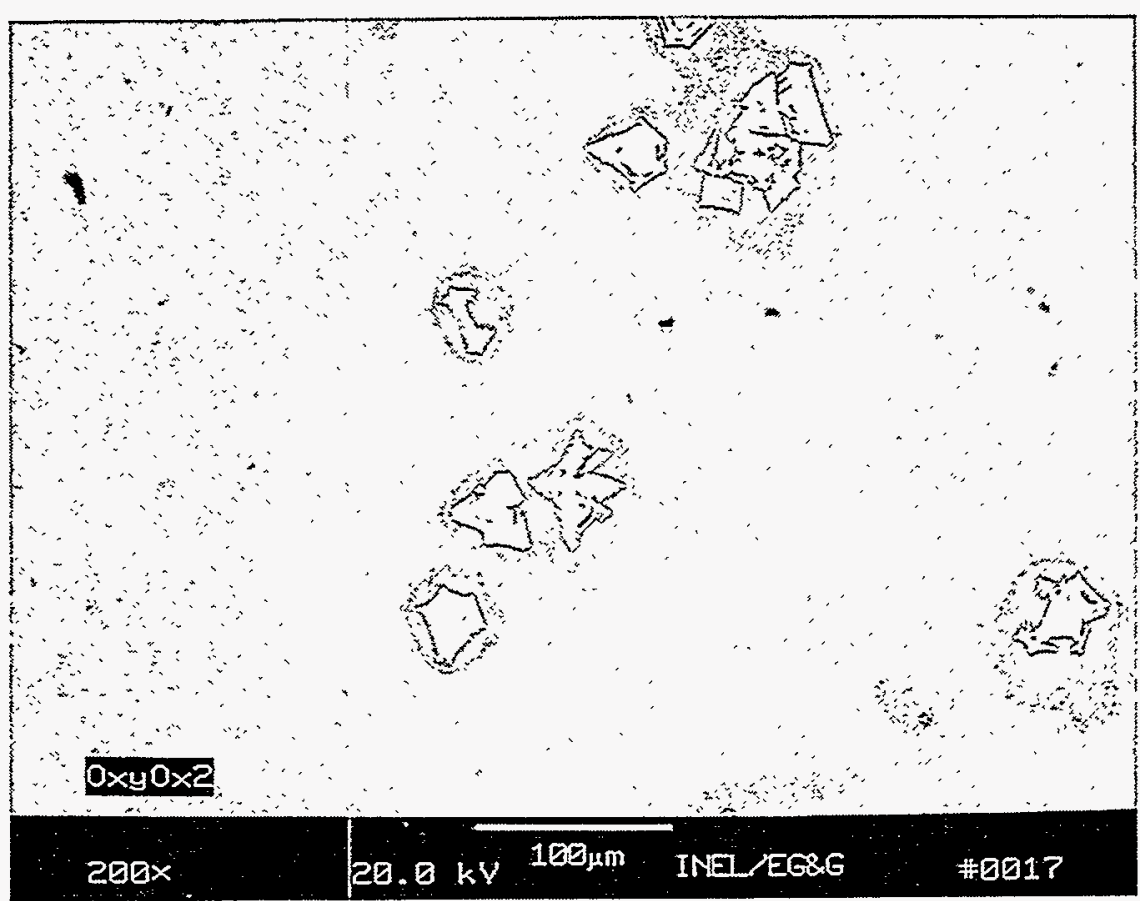

(a)

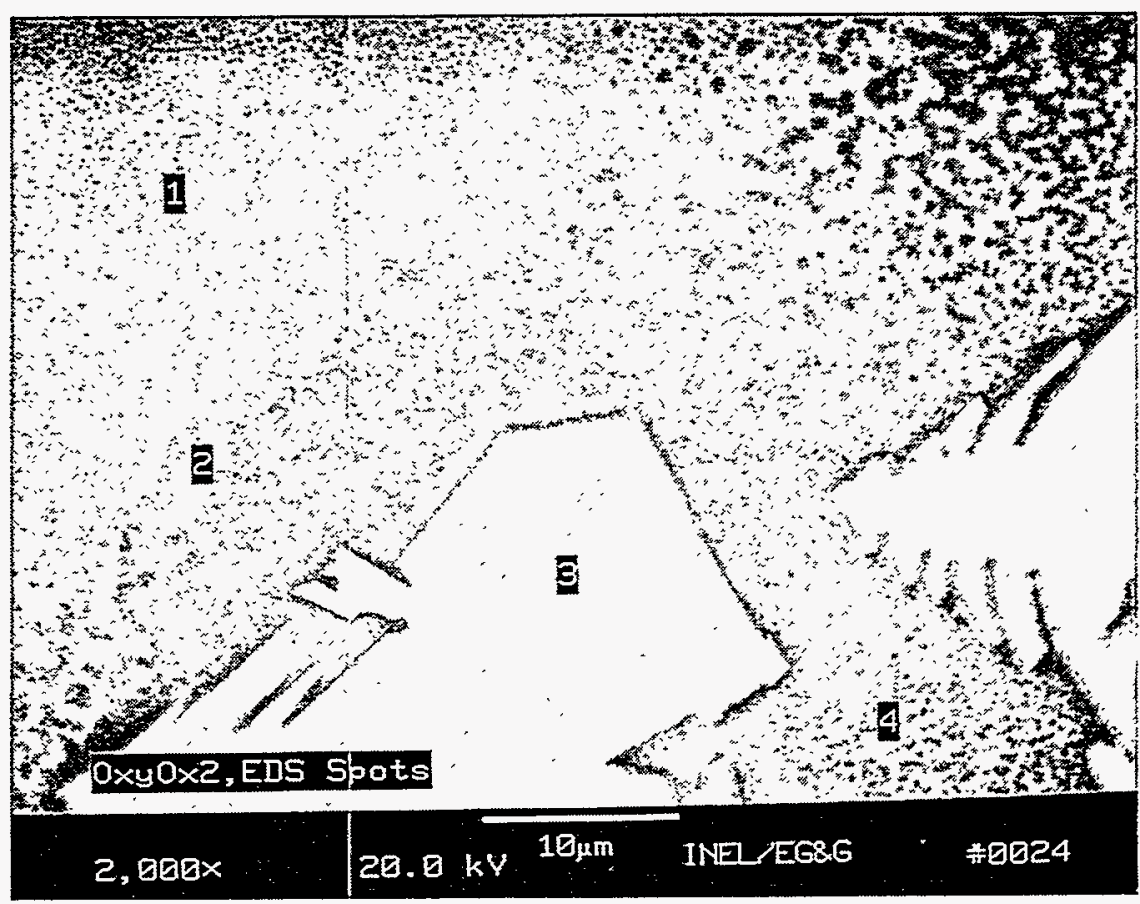

(b)

Figure 7.4 SEM micrographs for the slightly oxidized slags: (a) general area and (b) associated EDXS spots for different phases. 


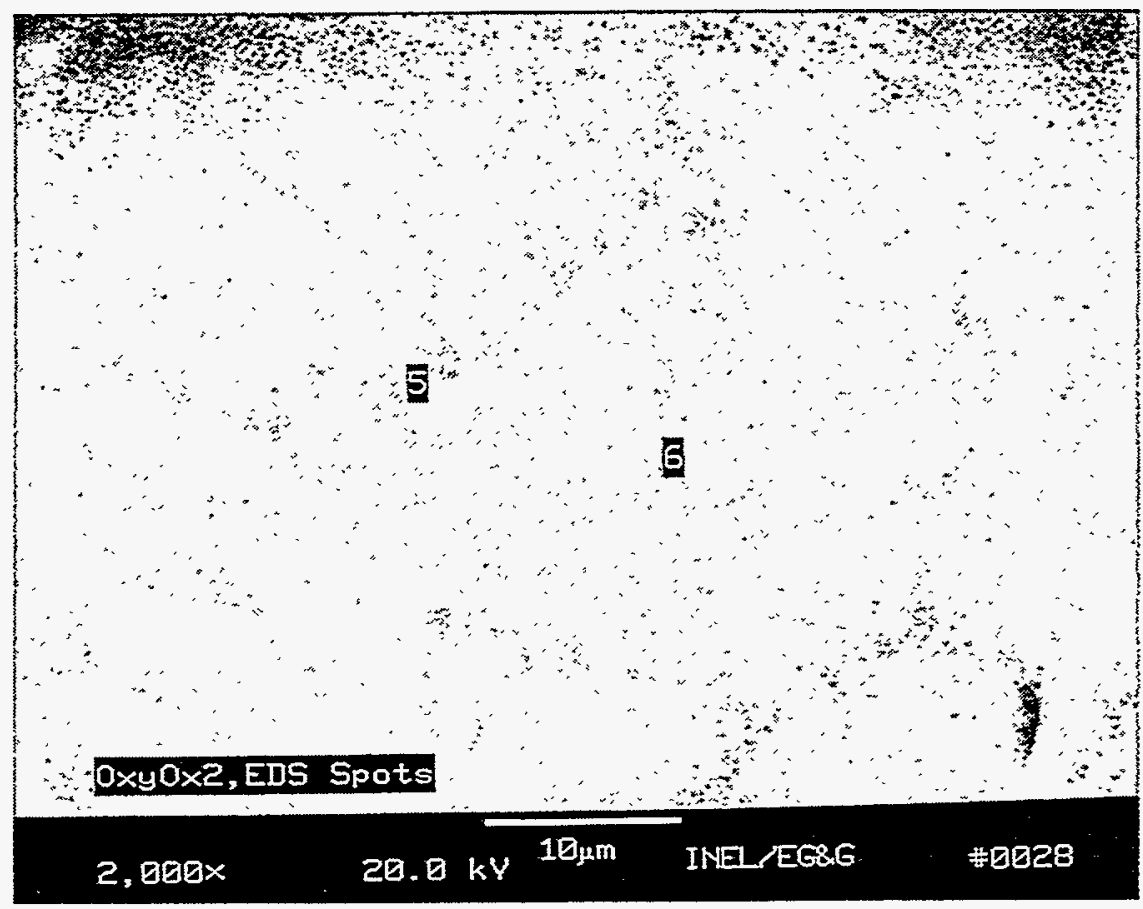

(c)

Figure 7.4 SEM micrographs for the slightly oxidized slags: (c) associated EDXS spots. 


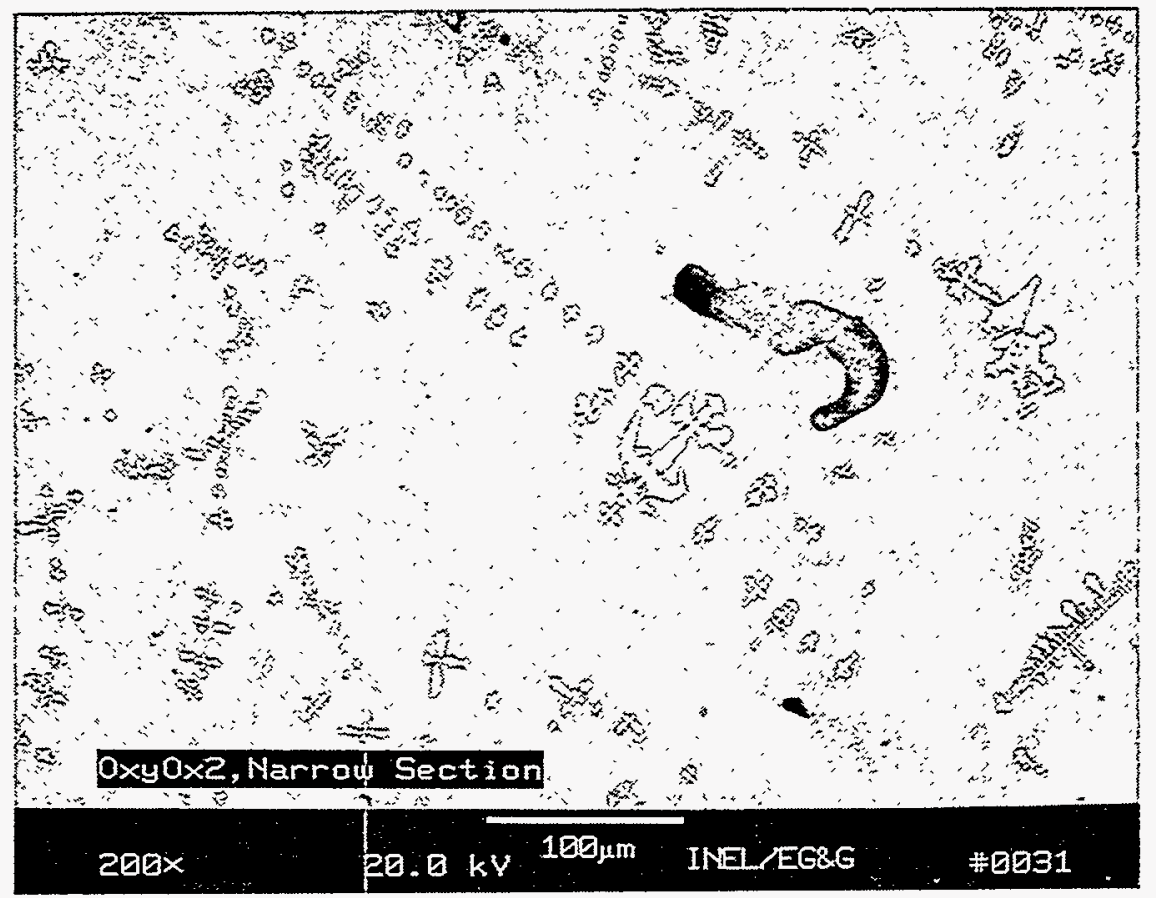

(d)

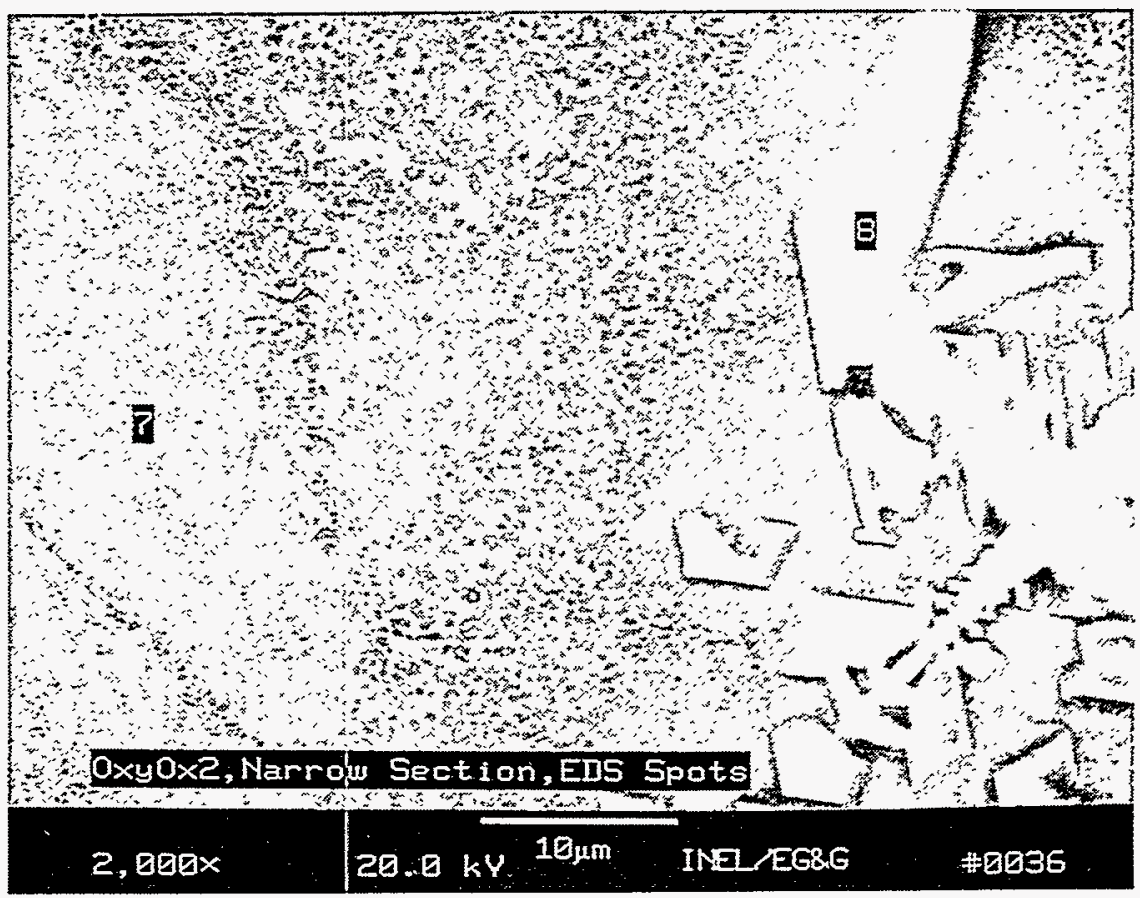

(e)

Figure 7.4 SEM micrographs for the slightly oxidized slags: (d) different general area and (e) associated EDXS spots for different phases. 
Table 7.5 EDXS analysis of designated spots for the slightly oxidized slag (OX02).

\begin{tabular}{|c|c|c|c|c|c|c|c|c|c|}
\hline & Ave & 1 & 2 & 3 & 4 & 5 & 6 & 7 & 8 \\
\hline $\mathrm{Na}_{2} \mathrm{O}$ & 2.28 & 2.08 & 1.42 & & 1.64 & 2.11 & 1.96 & 1.77 & \\
\hline $\mathrm{MgO}$ & 2.92 & 3.06 & 4.30 & 5.03 & 2.76 & & 3.51 & 3.28 & 5.07 \\
\hline $\mathrm{Al}_{2} \mathrm{O}_{3}$ & 9.96 & 10.07 & 8.34 & 4.87 & 10.83 & 9.71 & 10.08 & 9.84 & 5.89 \\
\hline $\mathrm{SiO}_{2}$ & 51.36 & 52.68 & 49.82 & 1.17 & 57.00 & 54.21 & 51.96 & 52.23 & 1.08 \\
\hline $\mathrm{K}_{2} \mathrm{O}$ & 1.74 & 1.85 & 1.25 & & 2.00 & 1.98 & 1.74 & 1.7 & \\
\hline $\mathrm{CaO}$ & 7.40 & 7.59 & 8.75 & & 7.69 & 3.89 & 8.66 & 7.95 & \\
\hline $\mathrm{TiO}_{2}$ & 4.91 & 5.13 & 5.33 & 1.11 & 3.32 & 3.18 & 5.19 & 5.59 & 2.68 \\
\hline $\mathrm{FeO}$ & 14.25 & 13.29 & 14.65 & 26.55 & 9.56 & 16.09 & 11.77 & 11.3 & 29.83 \\
\hline $\mathrm{ZrO}_{2}$ & 3.07 & 3.18 & 4.04 & & 3.35 & 3.46 & 3.22 & 4.06 & \\
\hline $\mathrm{CeO}_{2}$ & 0.84 & 0.70 & 0.68 & & tr & 1.70 & 0.07 & 0.36 & \\
\hline $\mathrm{Nd}_{2} \mathrm{O}_{3}$ & & & 0.74 & tr & 0.42 & 1.39 & 0.52 & 0.95 & \\
\hline $\mathrm{Sm}_{2} \mathrm{O}_{3}$ & tr & & 0.70 & tr & 0.35 & 1.07 & 0.35 & 0.41 & \\
\hline $\mathrm{Gd}_{2} \mathrm{O}_{3}$ & tr & & tr & tr & 0.57 & 1.03 & 0.59 & 0.57 & \\
\hline $\mathrm{Cs}_{2} \mathrm{O}$ & 0.38 & 0.38 & & & 0.52 & 0.18 & 0.46 & 0.36 & \\
\hline $\mathrm{Cr}_{2} \mathrm{O}_{3}$ & 0.89 & & & 60.53 & & & & & 54.71 \\
\hline $\mathrm{ZnO}_{\mathrm{PbO}}$ & & & & 0.74 & & & & & 0.74 \\
\hline $\mathrm{CdO}$ & & & & & & & & & \\
\hline $\mathrm{Photo}$ & & 0017 & 0024 & 0024 & 0024 & 0024 & 0028 & 0028 & 0036 \\
\hline
\end{tabular}

tr - trace 


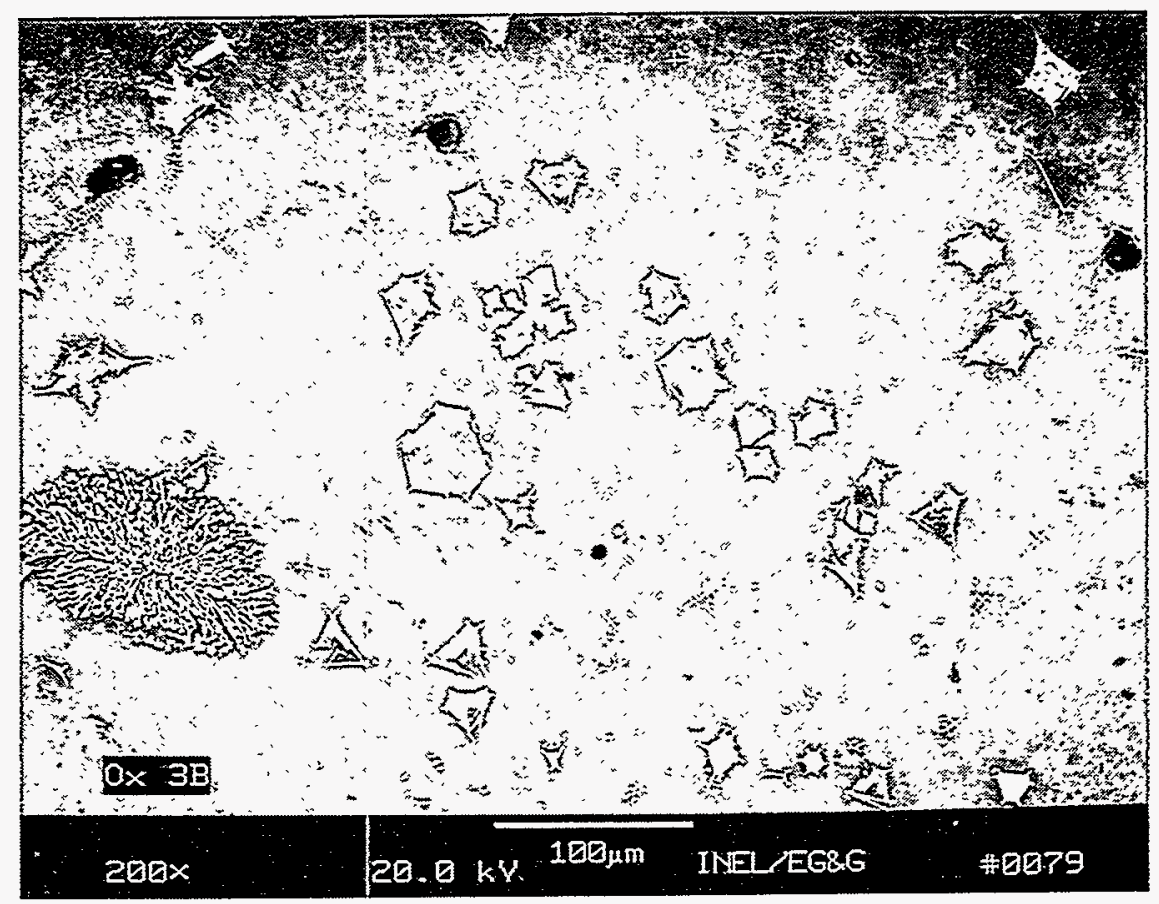

(a)

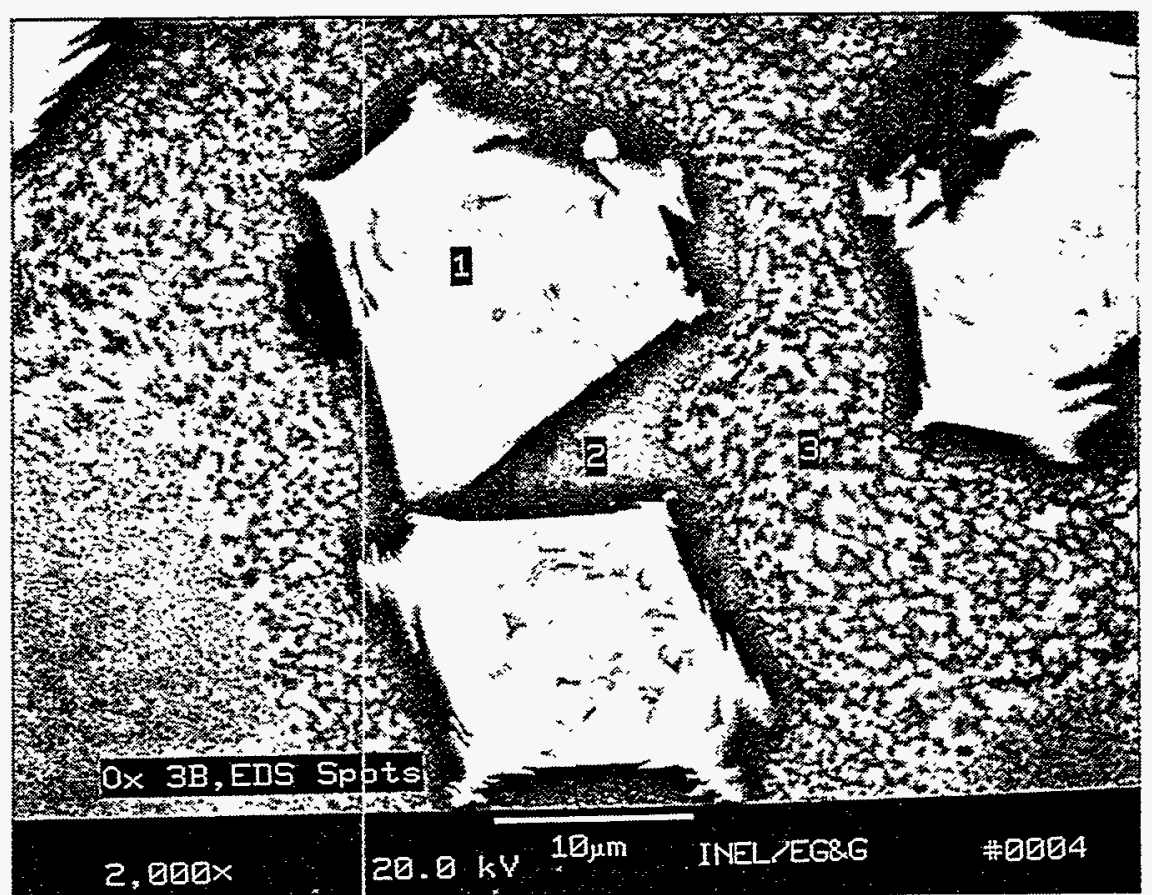

(b)

Figure 7.5 SEM micrographs for the highly oxidized slags: (a) general area and (b) associated EDXS spots for different phases. 


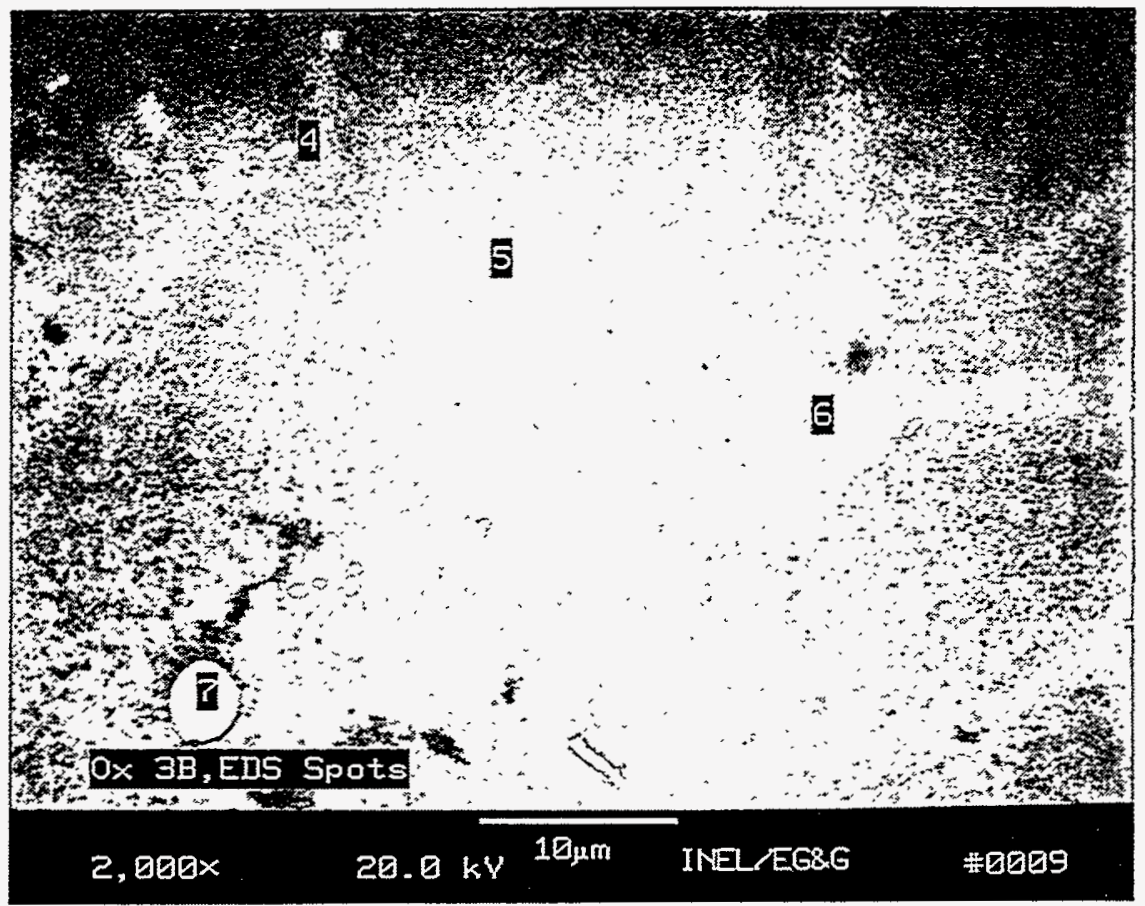

(c)

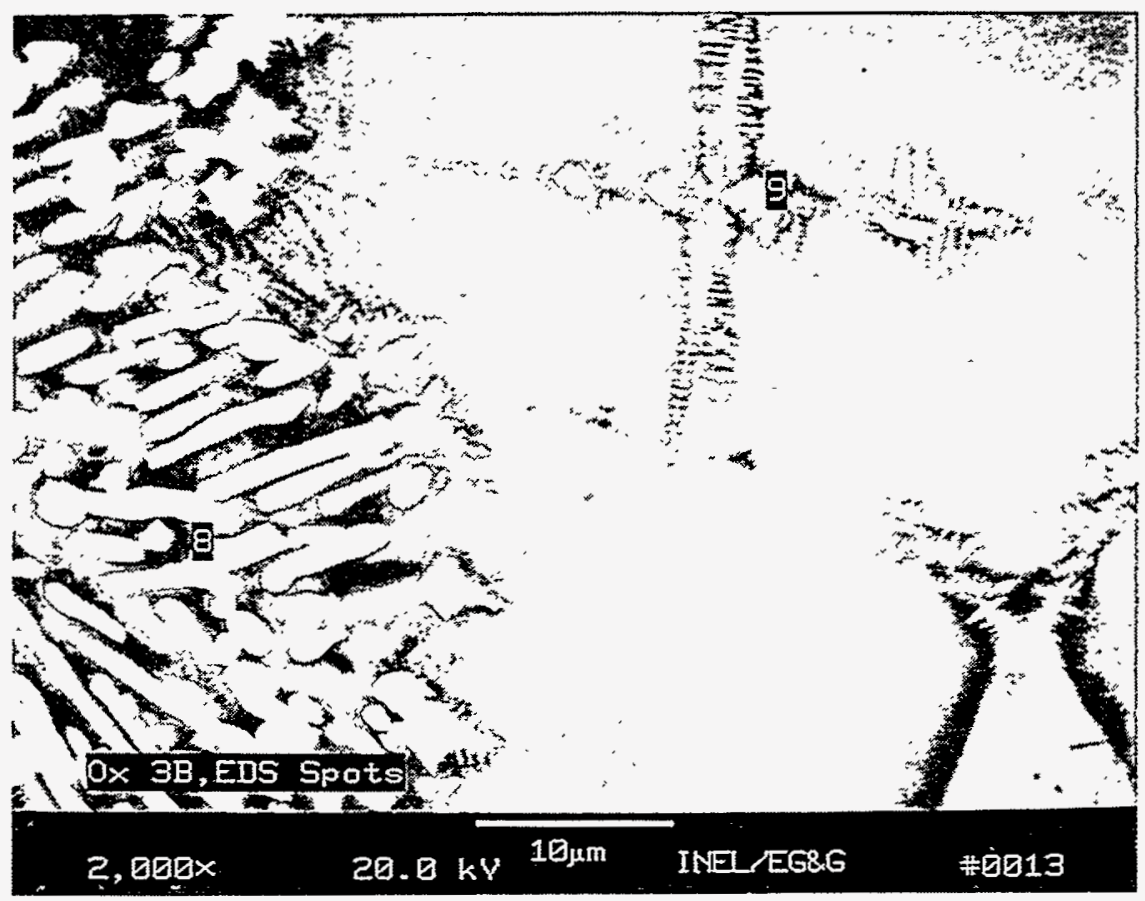

(d)

Figure 7.5 SEM micrographs for the highly oxidized slags: (c) and (d) associated EDXS spots for different phases. 
Table 7.6 EDXS analysis of designated spots in the highly oxidized slag (OX03).

\begin{tabular}{|c|c|c|c|c|c|c|c|c|c|c|}
\hline & Average & 1 & 2 & 3 & 4 & 5 & 6 & $7^{*}$ & 8 & 9 \\
\hline $\mathrm{Na}_{2} \mathrm{O}$ & 2.06 & & 1.92 & 2.14 & & 1.93 & 2.19 & & & 1.09 \\
\hline $\mathrm{MgO}$ & 2.73 & 5.38 & 1.65 & 2.27 & 2.62 & 3.24 & 0.84 & & & 2.36 \\
\hline $\mathrm{Al}_{2} \mathrm{O}_{3}$ & 9.03 & 4.02 & 11.6 & 9.88 & 6.47 & 9.38 & 8.84 & & 1.04 & 7.66 \\
\hline $\mathrm{SiO}_{2}$ & 49.6 & 1.09 & 59.0 & 54.0 & 27.5 & 49.3 & 53.4 & 0.92 & 9.83 & 31.4 \\
\hline $\mathrm{K}_{2} \mathrm{O}$ & 1.68 & & 2.30 & 2.05 & 0.64 & 1.68 & 1.84 & & & 1.38 \\
\hline $\mathrm{CaO}$ & 8.99 & & 6.52 & 7.88 & 3.02 & 10.2 & 7.25 & 0.15 & 0.99 & 1.25 \\
\hline $\mathrm{TiO}_{2}$ & 5.09 & 1.35 & 3.12 & 4.10 & 1.85 & 5.23 & 4.06 & 0.12 & 0.66 & 4.96 \\
\hline $\mathrm{FeO}$ & 15.4 & 48.0 & 7.93 & 10.4 & 4.75 & 12.2 & 10.6 & 1.57 & 1.34 & 47.3 \\
\hline $\mathrm{CuO}$ & 0.25 & 0.35 & & & 50.0 & & & 97.2 & & 0.23 \\
\hline $\mathrm{ZrO}_{2}$ & 3.92 & & 4.28 & 4.84 & 2.67 & 4.57 & 4.50 & & 86.1 & 1.32 \\
\hline $\mathrm{CeO}_{2}$ & 0.57 & 0.70 & 0.27 & tr & 0.11 & tr & 2.38 & & & \\
\hline $\mathrm{Nd}_{2} \mathrm{O}_{3}$ & 0.55 & & & 0.74 & 0.24 & 0.82 & 1.99 & & & \\
\hline $\mathrm{Sm}_{2} \mathrm{O}_{3}$ & $t r$ & & & 0.53 & 0.14 & 0.75 & 1.13 & & & \\
\hline $\mathrm{Gd}_{2} \mathrm{O}_{3}$ & 0.17 & & 0.34 & 0.53 & & 0.44 & 0.98 & & & \\
\hline $\mathrm{Cs}_{2} \mathrm{O}$ & & 0.38 & & 0.65 & & 0.28 & & & & 0.37 \\
\hline $\mathrm{Cr}_{2} \mathrm{O}_{3}$ & & 37.4 & & & & & & & & \\
\hline $\mathrm{ZnO}$ & 0.25 & 2.52 & & & & & & & & 0.69 \\
\hline $\mathrm{PbO}$ & & & & & & & & & & \\
\hline $\mathrm{CdO}$ & & & & & & & & & & \\
\hline $\mathrm{Photo} \#$ & 0079 & 0004 & 0004 & 0004 & 0009 & 0009 & 0009 & 0009 & 0013 & 0013 \\
\hline
\end{tabular}

\footnotetext{
* - metallic

tr - trace
} 


\subsection{Discussion}

The redox tests were performed as preliminary efforts to assess the ability of the laboratory arc furnace to operate under several reducing and oxidizing conditions. The furnace is small and the transients were large, yet the influence of redox conditions on microstructure was evident, even with the conditions of rapid cooling that occurred after melt termination. The reduced melts produced mostly glassy specimens, while oxidized melts developed substantially more crystalline material under similar cooling conditions. No zirconolite crystals were detected.

Table 7.7 shows overall results from the redox tests. Calculated values reflect the composition of the waste feed mix. The other columns show the general area EDX spectroscopy scans, which give the overall composition of the slags. A general comparison can be made in that the $\mathrm{SiO}_{2}$ percentage in the slags has increased due to the absence of the HVPMs and much of the surrogate mass. This is true of other compounds such as $\mathrm{Al}_{2} \mathrm{O}_{3}$, etc.

The disposition of the lanthanides was mixed. A significant portion of the cerium tended to remain in the glassy phases of the slag as did the samarium in the case of the reducing melts. Curiously, only trace amounts of samarium were found in the glassy matrix for the oxidizing melts, and Sm also did not appear in any crystalline phases. Neodymium and Gadolinium, which were used only in the oxidizing melts, did not appear in significant amounts in either glassy or crystalline phases, except for $\mathrm{Nd}$ in the glassy phase of the highly oxidized melt. Under reducing conditions, the additional surrogate, cesium, completely disappeared, while under oxidizing conditions, some of the metal remained in glassy phases of the slag.

With the exception of chromium, the HVPMs evaporated from the melt, regardless of the redox conditions. Chromium showed a strong affinity to iron in forming crystals under both reducing and oxidizing conditions, although the crystalline structures formed in reducing conditions tended to be much smaller and finer. 
Table 7.7 EDX general area scan analysis for the redox tests vs. calculated waste mix composition.

\begin{tabular}{|c|c|c|c|c|c|c|}
\hline & $\begin{array}{c}\text { Calculated } \\
\text { waste mix } \\
(\mathrm{wt} \%)\end{array}$ & $\begin{array}{c}\text { RED01 } \\
\text { slag } \\
\text { (wt\%) }\end{array}$ & $\begin{array}{c}\text { RED02 } \\
\text { slag } \\
\text { (wt\%) }\end{array}$ & $\begin{array}{l}\text { Calculated } \\
\text { waste mix } \\
\text { (wt\%) }\end{array}$ & $\begin{array}{c}\text { OX02 } \\
\text { slag } \\
\text { (wt\%) }\end{array}$ & $\begin{array}{c}\text { OX03B } \\
\text { slag } \\
\text { (wt\%) }\end{array}$ \\
\hline $\mathrm{Na}_{2} \mathrm{O}$ & 2.77 & 1.65 & 2.51 & 2.71 & 2.28 & 2.06 \\
\hline $\mathrm{MgO}$ & 3.03 & 2.96 & 2.84 & 2.97 & 2.92 & 2.73 \\
\hline $\mathrm{Al}_{2} \mathrm{O}_{3}$ & 8.83 & 11.33 & 10.29 & 8.64 & 9.96 & 9.03 \\
\hline $\mathrm{SiO}_{2}$ & 44.08 & 57.31 & 54.87 & 43.13 & 51.36 & 49.6 \\
\hline $\mathrm{K}_{2} \mathrm{O}$ & 2.25 & 1.92 & 2.05 & 2.20 & 1.74 & 1.68 \\
\hline $\mathrm{CaO}$ & 8.40 & 6.82 & 7.37 & 8.22 & 7.40 & 8.99 \\
\hline $\mathrm{TiO}_{2}$ & 3.95 & 4.64 & 5.13 & 3.86 & 4.91 & 5.09 \\
\hline $\mathrm{FeO}$ & 16.97 & 8.93 & 10.25 & 16.61 & 14.25 & 15.4 \\
\hline $\mathrm{ZrO}_{2}$ & 1.84 & 2.18 & 2.62 & 1.80 & 3.07 & 3.92 \\
\hline $\mathrm{CeO}_{2}$ & 0.99 & 0.54 & 0.54 & 0.99 & 0.84 & 0.57 \\
\hline $\mathrm{Nd}_{2} \mathrm{O}_{3}$ & & & & 0.99 & & 0.55 \\
\hline $\mathrm{Sm}_{2} \mathrm{O}_{3}$ & 0.99 & 0.41 & 0.34 & 0.99 & tr & tr \\
\hline $\mathrm{Gd}_{2} \mathrm{O}_{3}$ & & & & 0.99 & tr & 0.17 \\
\hline $\mathrm{Cs}_{2} \mathrm{O}$ & 0.99 & & & 0.99 & 0.38 & \\
\hline $\mathrm{Cr}_{2} \mathrm{O}_{3}$ & 1.45 & 1.30 & 1.20 & 1.45 & 0.89 & \\
\hline $\mathrm{ZnO}$ & 1.24 & & & 1.24 & & 0.25 \\
\hline $\mathrm{PbO}$ & 1.07 & & & 1.07 & & \\
\hline $\mathrm{CdO}$ & 1.14 & & & 1.14 & & \\
\hline Photo \# & & 0071 & 0083 & & 0017 & 0079 \\
\hline
\end{tabular}




\section{VOLATILIZATION TESTS (FY-94)}

\subsection{Introduction}

The purpose of the FY-94 HVPM tests was to determine methods to retain surrogates and HVPMs in the final waste form (IEB4/A-40). In order to analyze these methods, quantitative mass balances were needed during melter operations. An accurate mass balance was obtained by a procedure that was developed to measure all input and output materials. The arc melter system was modified to provide for complete particulate collection and thus allow accurate mass balances to be made.

\subsection{Experimental Conditions}

Six tests were run, using as controlled parameters: cold cap vs. non-cold cap conditions, using or not using a graphite feed tube extender, and thermally desorbing water from the simulated waste mix prior to processing in the arc melter. Table 8.1 shows the general parameters for each of the tests. The experiments began with a small amount of the IEB4/A-40 mix, usually $1.5 \mathrm{~kg}$, and a carbon steel ring (about $0.4 \mathrm{~kg}$ ) to initiate starting. Once the initial charge of material was melted, more mix was added either gradually or at faster rates in order to establish a cold cap. Average feed rates for operation are $94.7 \mathrm{~g} / \mathrm{min}$ with cold cap and 54.6 $\mathrm{g} / \mathrm{min}$ without cold cap. Details are given in Table 8.1. The function of the graphite feed tube extender was to limit the amount of dust and particulate generated as new material was being fed into the melt chamber. The last two tests used material that had been dried in an oven at $400^{\circ} \mathrm{C}$ for 2 hours then kept at above $100^{\circ} \mathrm{C}$ until being placed into the ceramic crucible and feeder hopper. The surrogates and HVPMs were added at this time.

All tests used IEB4/A-40 having $5 \mathrm{wt} \%$ each of $\mathrm{TiO}_{2}$ and $\mathrm{ZrO}_{2}$ and with HVPMs and surrogates in oxide form at $1 \mathrm{wt} \%$ each. Specific materials used were $\mathrm{PbO}$ (lead oxide), $\mathrm{ZnO}$ (zinc oxide), $\mathrm{CdO}$ (cadmium oxide), $\mathrm{Cr}_{2} \mathrm{O}_{3}$ (chromium oxide) as the HVPMs and $\mathrm{Cs}_{2} \mathrm{CO}_{3}$ (cesium carbonate), $\mathrm{CeO}_{2}$ (cerium [IV] oxide), and $\mathrm{Sm}_{2} \mathrm{O}_{3}$ (samarium oxide) as surrogate radionuclides. The normal coloring of the total mix was black (due to $\mathrm{Fe}_{3} \mathrm{O}_{4}$ ), but for the mixes which underwent thermal desorbtion, the color changed to red $\left(\mathrm{Fe}_{2} \mathrm{O}_{3}\right)$.

For each test about $5.0 \mathrm{~kg}$ of soil mixture was used. Therefore, after placing material in the crucible, as mentioned above the remaining amount would be placed in the feed hopper. The can assembly and the lid are then clamped together and cooling water flow initiated through the can assembly, electrodes, and lid. Plant air is supplied to the view port to prevent dust collection and the exhaust eductor to dilute and cool the exhaust gases. 
Table 8.1 General parameters and feeding information for the FY-94 HVPM runs.

\begin{tabular}{|c|c|c|c|c|c|}
\hline Test Name & $\begin{array}{c}\text { Starting material } \\
\text { amount } \\
(\mathrm{kg}) \\
\end{array}$ & Type of run & $\begin{array}{l}\text { Feed } \\
\text { rate } \\
(\mathrm{g} / \mathrm{min})\end{array}$ & $\begin{array}{c}\text { Feed } \\
\text { duration } \\
\text { (mins) }\end{array}$ & $\begin{array}{l}\text { Amount } \\
\text { fed } \\
(\mathrm{kg})\end{array}$ \\
\hline ARM082394 & $\begin{array}{c}0.750 \mathrm{~kg} \text { IEB } 4 / \mathrm{A}-40 \\
+ \text { HVPMs } \\
+ \text { surrogates }\end{array}$ & $\begin{array}{l}\text { no cold cap, } \\
\text { no extension tube }\end{array}$ & 22.6 & 100 & 2.257 \\
\hline ARM082694 & $\begin{array}{c}1.500 \mathrm{~kg} \mathrm{IEB} 4 / \mathrm{A}-40 \\
+\mathrm{H}+\mathrm{S}\end{array}$ & $\begin{array}{c}\text { cold cap, } \\
\text { no extension tube }\end{array}$ & 97.9 & 33 & 3.230 \\
\hline ARM090694 & $\begin{array}{c}1.500 \mathrm{~kg} \mathrm{IEB} 4 / \mathrm{A}-40 \\
+\mathrm{H}+\mathrm{S}\end{array}$ & $\begin{array}{l}\text { no cold cap, } \\
\text { extension tube }\end{array}$ & 56.8 & 52 & 2.950 \\
\hline ARM090894 & $\begin{array}{c}1.500 \mathrm{~kg} \mathrm{IEB} 4 / \mathrm{A}-40 \\
+\mathrm{H}+\mathrm{S}\end{array}$ & $\begin{array}{l}\text { cold cap, } \\
\text { extension tube }\end{array}$ & 70.3 & 47 & 3.303 \\
\hline ARM092094 & $\begin{array}{c}1.500 \mathrm{~kg} \mathrm{IEB} 4 / \mathrm{A}-40 \\
+\mathrm{H}+\mathrm{S}\end{array}$ & $\begin{array}{l}\text { no cold cap, } \\
\text { extension tube, } \\
\text { thermal desorbtion }\end{array}$ & 84.6 & 48 & 4.063 \\
\hline ARM092294 & $\begin{array}{c}1.683 \mathrm{~kg} \mathrm{IEB} 4 / \mathrm{A}-40 \\
+\mathrm{H}+\mathrm{S}\end{array}$ & $\begin{array}{l}\text { cold cap, } \\
\text { extension tube, } \\
\text { thermal desorbtion }\end{array}$ & 115.8 & 30 & 3.473 \\
\hline
\end{tabular}

Typical flow rates are $1.0 \mathrm{slm}$ and 50-55 slpm, respectively. All points are verified to be indicating properly, and a record file is set up. The electrodes are positioned so that they both just touch the starter ring. A video camera adapted with a pin-hole aperture is positioned over the view port, and the video equipment (camera power supply, video cassette recorder, and monitor) is energized and verified to be operating properly. As for all previous experiments, prior to arc initiation the data acquisition system is placed in the SCAN and RECORD modes. The data acquisition system is programmed to accumulate one complete data set per minute. 
The power supply is then energized with the adjustment knob set at zero. An indication of voltage $(\sim 50$ volts DC) far below open circuit voltage $(\sim 480$ volts DC) means that a conducting path has been established between the graphite electrodes and carbon steel ring. The power is then adjusted to maintain a stable arc. The electrode arc gaps are controlled so that voltage is maintained between 50 and 250 volts DC. Typical values after initial startup are 110200 volts $\mathrm{DC}$, and $80-130$ amps. This condition is maintained until the molten material covers the complete surface and then feeding commences. Cold cap vs. noncold cap conditions were accomplished by different power level adjustments and material feed rate variances. Operational data for each test are presented in Table 8.2.

Table 8.2 Data and operating conditions for the FY-94 experiments.

\begin{tabular}{|c|c|c|c|c|c|}
\hline Test name & Date & $\begin{array}{c}\text { Run } \\
\text { time } \\
(\mathrm{min})\end{array}$ & $\begin{array}{c}\text { Ave temp } \\
\left({ }^{\circ} \mathrm{C}\right)\end{array}$ & $\begin{array}{c}\text { Ave power } \\
\left({ }^{\circ} \mathrm{C}\right)\end{array}$ & $\begin{array}{c}\text { Shutdown } \\
\text { condition }\end{array}$ \\
\hline ARM082394 & $8 / 23 / 94$ & 109 & 1543 & 19.1 & normal \\
\hline ARM082694 & $8 / 26 / 94$ & 64 & 1746 & 21.0 & normal \\
\hline ARM090694 & $9 / 06 / 94$ & 75 & 1695 & 17.4 & normal \\
\hline ARM090894 & $9 / 08 / 94$ & 64 & 1619 & 18.0 & normal \\
\hline ARM092094 & $9 / 20 / 94$ & 89 & 1562 & 19.9 & normal \\
\hline ARM092294 & $9 / 22 / 94$ & 56 & 1683 & 20.3 & normal \\
\hline
\end{tabular}

Each melt started with a new filter installed and would operate until the filter loading caused a pressure drop of 5.0 inches of water, then it would be bypassed, removed, and replaced. Total off-gas loading was calculated by weighing the filter papers and determining a time averaged loading based on all the filters collected during that run. Typical amounts of time that the filter would be online ranged from 2 to 7 minutes. 


\subsection{Data Collection}

Sample collection and classification for the FY-94 work was broken into five areas: unused feed, material recovered from the lid and head space above the melt, material recovered from exhaust lines, material recovered from the cyclone, and off-gas filter samples. Modifications were made to the off-gas system for the FY-94 work to allow for collection of particulate from these areas for mass balance calculations. A photo and a schematic of the modified off-gas system can be seen in Figures 3.4 and 3.5. The exhaust equipment consists of a piece of 1.25-inch stainless steel tubing approximately 36 inches in length and straight walled, a diffuser shaped vacuum fitting, a venturi chamber where additional air is supplied at the throat at an approximate rate of 50-60 slm, a cyclonic separator with sample container, filter box and bypass piping, and the baghouse.

Sampling of off-gas particulate is obtained in a batch operation. Typically a filter was left in place until the differential pressure across it reached 5 inches of water. It was then bypassed, isolated, and replaced with a new filter. Filters would remain online for an average of 5-6 minutes and would collect approximately 1-2 grams of particulate. Usually 4 to 5 filters were utilized during a run. The color of the deposit on the filter would vary depending on melter operating conditions.

The cyclone separator removed little particulate material from the exit gas stream. However, for most runs moisture would condense into the cyclone collection can. The quantity of moisture found here was on the order of 5-25 ml. There was no liquid found in the cyclone collection can for the last two runs where the soil was preheated to drive off moisture.

Additional particulate sample collection was done during the cleanup phase of the operation. These samples were the scrapings from under the lid (to include water cooled electrode tube walls), brushings from exhaust components minus the cyclone (which was collected separately), and the feed hopper (including feed tube). The material collected from the lid and electrode tube areas tended to be of a scalely crust most probably due to the condensation promoted by the water-cooled lid and electrodes.

The usual color of this residue was yellow to orange and red. The material collected from the exhaust components tended to be darker in color than the lid and electrode material with an appearance from gray to black. The material would collect at highest concentrations at the entrance to the exhaust line, expansion section, and upstream side of the venturi. Of the materials collected, slag (both top and bottom sections), and filter samples were aliquoted for the purpose of $\mathrm{X}$-ray fluorescence (XRF) analysis. Sample aliquots were also taken on the slag, lid, and filter 
materials for the purpose of energy dispersive x-ray emission (EDXS) analysis. Lastly, sample aliquots were obtained for the intent of performing moisture analysis of the various samples in house, and metals analysis of samples from slag, combined exhaust and lid and filters were contracted out. One sample of combined exhaust and lid aliquot which was sent out for wet chemistry analysis (ICP/EAS and FLAA) was spiked with 0.25 grams calcium carbonate (sample $\mathrm{A} 0826 \mathrm{EL})$ for quality assurance considerations.

\subsection{General Mass Balance}

A material mass balance of general proportions can be obtained by consideration of the various inputs and outputs of the melter system as shown in Table 8.3. The column labeled "Refractory liner" is the start weight of the liner. The regular refractory liner does not reach up to the top of the stainless steel crucible, and a refractory liner extension is used to cover the upper portion of the crucible. Small amounts of slag occasionally splash up onto this liner extension. The filters were not in continuous use during any of the runs. Therefore, some mass was lost as particulate through the bypass exhaust when filters were not in place. The amount of mass collected and time in place of each filter was recorded so that an average particulate flow in the exhaust stream can be calculated. This rate is about $0.3 \mathrm{~g} / \mathrm{min}$, but varies for each experiment. Multiplying the rate with the total time of experiment yields the total amount of particulate lost in the exhaust gas stream. This is the figure listed in the "Filters" column. In this way, particulate lost when the filters were not in use can be accounted for. The rest of the columns are self-explanatory being dust collected in the other areas of the exhaust system or materials that were added into the melt. The start weight in the column labeled "Total IEB4/A-40" includes the amount of A-40 put into the crucible before prior to starting (see Table 8.1). Since all the solids have been accounted for, the solid mass loss, listed in the last column, is therefore assumed to be made up of material lost in the conversion carbonates and hydrates as solids into gaseous $\mathrm{CO}_{2}$ and $\mathrm{H}_{2} \mathrm{O}$. Except for run ARM092094 which is $17.8 \mathrm{wt} \%$, this weight loss amount ranges from $10-13 \mathrm{wt} \%$ of the original IEB4/A-40 used during the experiment. The weight loss average for all the runs is $13.1 \mathrm{wt} \%$. 
Table 8.3a Mass balance information for the FY-94 HVPM experiments.

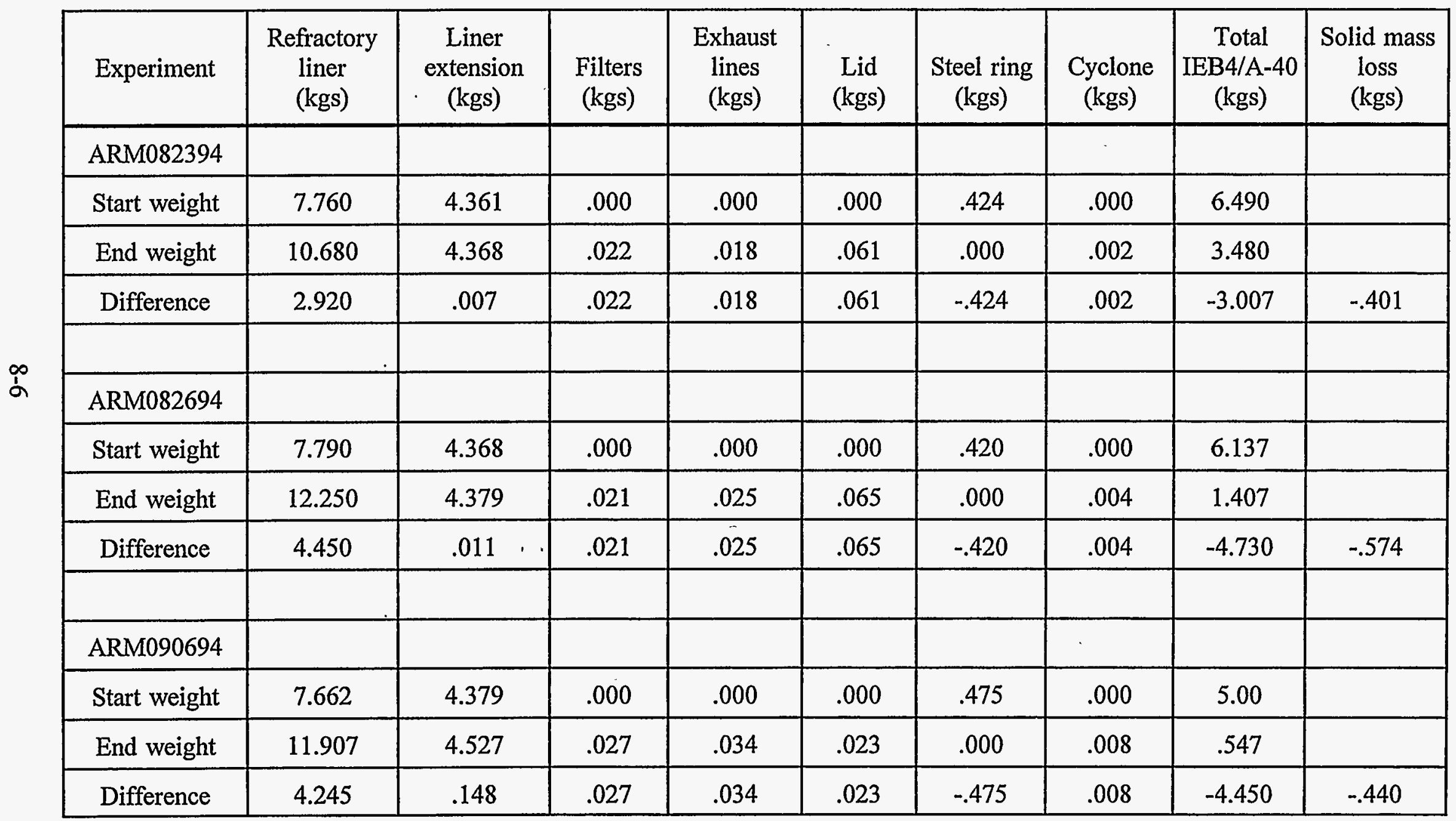


Table $8.3 \mathrm{~b}$ Mass balance information for the FY-94 HVPM experiments.

\begin{tabular}{|c|c|c|c|c|c|c|c|c|c|}
\hline Experiment & $\begin{array}{c}\text { Refractory } \\
\text { liner } \\
\text { (kgs) }\end{array}$ & $\begin{array}{l}\text { Liner } \\
\text { extension } \\
\text { (kgs) }\end{array}$ & $\begin{array}{c}\text { Filters } \\
\text { (kgs) }\end{array}$ & $\begin{array}{c}\text { Exhaust } \\
\text { lines } \\
\text { (kgs) }\end{array}$ & $\begin{array}{c}\text { Lid } \\
\text { (kgs) }\end{array}$ & $\begin{array}{l}\text { Steel ring } \\
\quad \text { (kgs) }\end{array}$ & $\begin{array}{c}\text { Cyclone } \\
\text { (kgs) }\end{array}$ & $\begin{array}{c}\text { Total } \\
\text { IEB4/A-40 } \\
\text { (kgs) }\end{array}$ & $\begin{array}{l}\text { Solid mass } \\
\text { mismatch } \\
\text { (kgs) }\end{array}$ \\
\hline \multicolumn{10}{|l|}{ ARM090894 } \\
\hline Start weight & 7.900 & 4.366 & .000 & .000 & .000 & .427 & .000 & 5.000 & \\
\hline End weight & 12.430 & 4.368 & .024 & .033 & .039 & .000 & .007 & 0.197 & \\
\hline Difference & 4.530 & .002 & $.024^{\circ}$ & .033 & .039 & -.427 & .007 & -4.803 & -.595 \\
\hline \multicolumn{10}{|l|}{ ARM092094 } \\
\hline Start weight & 7.930 & 4.368 & .000 & .000 & .000 & .373 & .000 & 5.740 & . \\
\hline End weight & 12.788 & 4.373 & .023 & .024 & .035 & .000 & .003 & 0.177 & \\
\hline Difference & 4.858 & .005 & .023 & .024 & .035 & -.373 & .003 & -5.563 & -.988 \\
\hline \multicolumn{10}{|l|}{ ARM092294 } \\
\hline Start weight & 7.551 & 4.373 & .000 & .000 & .000 & .337 & .000 & 5.350 & \\
\hline End weight & 12.237 & 4.384 & .035 & .038 & .056 & .000 & .005 & 0.194 & \\
\hline Difference & 4.686 & .011 & .035 & .038 & .056 & -.337 & .005 & -5.156 & -.662 \\
\hline
\end{tabular}




\subsection{Off-Gas Particulate Analysis}

Off-gas particulate evolved during operation of the melting process collects on the walls and top of the melting chamber or lid. A portion of the produced particulate is transported by the exhaust gases to filters located in the lines leading between the melt chamber and baghouse. As feed material was added to the process, the off-gas flow was diverted through these filters to collect representative samples of the evolved particulate. Over the period of one run, a number of filters were introduced to collect samples. Following termination of the run, the melt chamber was dissembled, and material deposited on the lid was removed and sampled.

Analyses for the particulates and the slags were done twice. The first analysis used XRF spectroscopy and EDX spectroscopy. The second analysis was done by an independent laboratory using ICP spectroscopy and FLAA spectroscopy.

\subsubsection{EDXS and XRF Analysis of Exhaust Filter Particulate}

This section details the $x$-ray chemical analyses obtained for the material collected on the filters and condensate collected from the chamber head. Two types of $\mathrm{x}$-ray analysis methods were employed to determine the metal/elemental composition of these samples, XRF and EDX spectroscopy. These methods obtain chemical information by bombardment of the prepared sample using either $\mathrm{x}$-rays in the case of XRF or electrons for EDX. The resulting $\mathrm{x}$-ray emissions were analyzed relative to internal and prepared standards to obtain elemental composition. The relative error of these measurements was estimated to be approximately \pm 5 to $8 \%$ of the reported value.

Table 8.4 shows the averaged results of the EDX and XRF analyses. The full data set is contained in Appendix E. The average was taken using both EDX and XRF data. In cases where only XRF or EDX data were available, the data for either the XRF or EDX cases were ignored. If zero values were part of either the EDX or XRF data, they were used in the averaging. Dashes in the table indicate that data were not taken or the concentration of the element was below detection limits for the instrument.

In all cases, the majority constituents in the filter particulate is zinc, cadmium, and lead at an levels between 15-20 wt\%. Cesium was present at levels of several percent along with silicon, iron, and potassium in most cases (See Appendix E). Considering the 
Table 8.4 EDXS and XRF analysis - Average concentrations for HVPMs and surrogates in exhaust filter particulate.

\begin{tabular}{|c|c|c|c|c|c|c|}
\hline Element & $\begin{array}{c}\mathrm{ARM} \\
082394 \\
(\mathrm{ppm})\end{array}$ & $\begin{array}{c}\mathrm{ARM} \\
082694 \\
(\mathrm{ppm})\end{array}$ & $\begin{array}{c}\text { ARM } \\
090694 \\
(\mathrm{ppm})\end{array}$ & $\begin{array}{c}\text { ARM } \\
090894 \\
(\mathrm{ppm})\end{array}$ & $\begin{array}{c}\text { ARM } \\
092094 \\
(\mathrm{ppm})\end{array}$ & $\begin{array}{c}\text { ARM } \\
092294 \\
(\mathrm{ppm})\end{array}$ \\
\hline $\mathrm{Cr}$ & - & - & 3700 & 1840 & 2100 & 1950 \\
\hline $\mathrm{Zn}$ & 187850 & 142075 & 163425 & 187710 & 217150 & 237830 \\
\hline $\mathrm{Cd}$ & 163575 & 129225 & 223975 & 155100 & 178750 & 221425 \\
\hline $\mathrm{Cs}$ & 72900 & 17450 & 53340 & 52900 & 19550 & 18125 \\
\hline $\mathrm{Ce}$ & 870 & 578 & - & - & - & - \\
\hline $\mathrm{Sm}$ & 1440 & 943 & - & - & - & - \\
\hline $\mathrm{Pb}$ & 167900 & 165325 & 208000 & 138700 & 266000 & 215200 \\
\hline
\end{tabular}

overall amounts of HVPMs and surrogates, the cold cap tests (ARM082694, ARM090894, and ARM092294) were only somewhat effective in reducing volatilization. In certain cases for specific elements, data indicate a slight increase in the volatilization in the cold cap test vs. the noncold cap test.

\subsubsection{ICP Analysis of Exhaust Filter Particulate}

Table 8.5 shows the averaged results of the ICP spectroscopic chemical analyses. FLAA spectroscopy was used to determine cesium concentrations only. The full data set for the ICP and FLAA analyses is contained in Appendix F. In this analysis, the filters containing particulate were prepared using microwave digestion then analyzed. Because both the filter and particulate were analyzed, a plain filter sample was also analyzed so the data from this could be subtracted from the filter plus particulate samples, yielding the elemental concentrations for the particulate only. The plain filter sample was composed primarily ( $98 \mathrm{wt} \%$, metals basis only) of silicon with small amounts sodium, calcium, and aluminum plus trace elements. 
Once again the majority constituents in the filter particulate are found to be zinc, cadmium, and lead at levels approaching between 15-20 wt\%. The overall results compare reasonably well with the EDXS and XRF analysis. Cesium was present at levels of several percent, and cerium and samarium exist in amounts of only tenths and hundredths of a percent. The data in Table 8.5 suggest there is no correlation in reductions of HVPMs and surrogates in the cold cap melts, since about half the time the concentrations for specific elements increase slightly rather than decrease.

Table 8.5 ICP analysis - Average concentrations for HVPMs and surrogates in exhaust filter particulate.

\begin{tabular}{|c|c|c|c|c|c|c|}
\hline Element & $\begin{array}{c}\mathrm{ARM} \\
082394 \\
(\mathrm{ppm})\end{array}$ & $\begin{array}{c}\text { ARM } \\
082694 \\
(\mathrm{ppm})\end{array}$ & $\begin{array}{c}\text { ARM } \\
090694 \\
(\mathrm{ppm})\end{array}$ & $\begin{array}{c}\text { ARM } \\
090894 \\
(\mathrm{ppm})\end{array}$ & $\begin{array}{c}\text { ARM } \\
092094 \\
(\mathrm{ppm})\end{array}$ & $\begin{array}{c}\text { ARM } \\
092294 \\
(\mathrm{ppm})\end{array}$ \\
\hline $\mathrm{Cr}$ & 1339 & 2160 & 2062 & 2197 & 2033 & 1593 \\
\hline $\mathrm{Zn}$ & 78972 & 100826 & 100575 & 142435 & 123782 & 159001 \\
\hline $\mathrm{Cd}$ & 99876 & 127778 & 142407 & 168418 & 214363 & 197526 \\
\hline $\mathrm{Cs}$ & 21413 & 33279 & 46176 & 45799 & 33776 & 29549 \\
\hline $\mathrm{Ce}$ & 504 & 1077 & 796 & 1163 & 210 & 213 \\
\hline $\mathrm{Sm}$ & 149 & 123 & 156 & 113 & 16 & 21 \\
\hline $\mathrm{Pb}$ & 136296 & 164793 & 132186 & 146597 & 147130 & 173313 \\
\hline
\end{tabular}

\subsubsection{EDX and XRF Analysis of Melter Chamber Particulate}

Table 8.6 shows the elemental composition of material removed from the cover of the arc melter chamber. Most of the elements present in the material added to the melter are present in the condensate. Major constituents are cadmium, iron, lead, and zinc. Cerium and samarium are present in measurable amounts. The HVPMs, particularly cadmium, are in higher concentrations than in the filter particulate collected downstream in the exhaust system. Samples for the last two experiments were not collected. 
Table 8.6 EDX and XRF melter chamber condensate/particulate analysis.

\begin{tabular}{|c|c|c|c|c|}
\hline Element & ARM082394 & ARM082694 & ARM090694 & ARM090894 \\
\hline $\mathrm{Na}$ & 0 & 0 & 0 & 0 \\
\hline $\mathrm{Mg}$ & 0 & 0 & 0 & 0 \\
\hline $\mathrm{Al}$ & 0 & 0 & 0 & 0 \\
\hline $\mathrm{Si}$ & 26800 & 13000 & 7300 & 10900 \\
\hline $\mathrm{K}$ & 16200 & 21000 & 18800 & 14900 \\
\hline $\mathrm{Ca}$ & 26900 & 17000 & 20000 & 20100 \\
\hline $\mathrm{Ti}$ & 23800 & 15000 & 25900 & 24500 \\
\hline $\mathrm{Fe}$ & 146200 & 72600 & 125200 & 141300 \\
\hline $\mathrm{Zn}$ & 155600 & 175600 & 190000 & 161700 \\
\hline $\mathrm{Zr}$ & 27200 & 12300 & 22000 & 26700 \\
\hline $\mathrm{Cd}$ & 313000 & 358400 & 378300 & 166200 \\
\hline $\mathrm{Cs}$ & 18000 & 15600 & 31100 & 12100 \\
\hline $\mathrm{Ce}$ & 7600 & 4600 & .5900 & 3000 \\
\hline $\mathrm{Sm}$ & 9900 & 6700 & 9200 & 13500 \\
\hline $\mathrm{Pb}$ & 230400 & 199500 & 219900 & 161700 \\
\hline
\end{tabular}




\subsubsection{ICP Analysis of Melter Chamber Particulate.}

Data in Table 8.7 for the ICP spectroscopic analysis of HVPMs and surrogates correlates well with in Table 8.6 using EDXS and XRF analyses, in particular the somewhat higher levels of cadmium found in the chamber particulate as compared to filter particulates downstream. Data on the other elements can be found in Appendix F.

Table 8.7 ICP analysis - Average concentrations for HVPMs and surrogates for particulate collected from the melter chamber.

\begin{tabular}{|c|c|c|c|c|c|c|}
\hline Element & $\begin{array}{c}\text { ARM } \\
082394 \\
(\mathrm{ppm})\end{array}$ & $\begin{array}{c}\text { ARM } \\
082694 \\
(\mathrm{ppm})\end{array}$ & $\begin{array}{c}\text { ARM } \\
090694 \\
(\mathrm{ppm})\end{array}$ & $\begin{array}{c}\text { ARM } \\
090894 \\
(\mathrm{ppm})\end{array}$ & $\begin{array}{c}\text { ARM } \\
092094 \\
(\mathrm{ppm})\end{array}$ & $\begin{array}{c}\text { ARM } \\
092294 \\
(\mathrm{ppm})\end{array}$ \\
\hline $\mathrm{Cr}$ & 1089 & 1345 & 3212 & 2908 & 3346 & 2329 \\
\hline $\mathrm{Zn}$ & 123941 & 95776 & 108560 & 104802 & 138395 & 157266 \\
\hline $\mathrm{Cd}$ & 262825 & 243015 & 240691 & 246378 & 279838 & 238345 \\
\hline $\mathrm{Cs}$ & 34700 & 21448 & 47142 & 36836 & 45717 & 29809 \\
\hline $\mathrm{Ce}$ & 4458 & 613 & 687 & 1308 & 1001 & 623 \\
\hline $\mathrm{Sm}$ & 5972 & 193 & 421 & 6950 & 672 & 507 \\
\hline $\mathrm{Pb}$ & 238847 & 285003 & 162706 & 148894 & 176772 & 178987 \\
\hline
\end{tabular}

\subsection{Slag Composition Analysis}

Coincident with the XRF, EDXS, and ICP spectroscopic analyses of the particulate materials, samples of the resulting slags were also analyzed. Two samples of each melt were analyzed, one from the top portion of the melt and a second from the lower portion of the melt. The location within the melt was thought to be important in determining if mixing or stratification of the melt was occurring. Since the slag is composed of both a glass matrix and distributed distinct crystals, the applicability of XRF and EDXS for complete characterization of the exact composition of the slag is questionable. Both of these methods yield concentration 
values that are averaged over an observation area. Elements that tend to segregate or congregate into localized areas can be overstated or understated by these methods. For example, zirconium tends to concentrate in large dendritic grains or crystals that spread across the melt. EDXS analyses of samples where these large crystals are exposed to detection display elevated concentrations of zirconium. These concentration values are judged high based on the original amount of oxide added and corresponding values obtained using XRF on the same and similar samples. Therefore, elements found to segregate are better defined relative to composition by using wet chemical methods (ICP and FLAA spectroscopy) than the $\mathrm{x}$-ray methods (EDX and $\mathrm{XRF}$ ) which are good indicators of elemental presence rather than precise data values when concentrations are low. EDX measurement values below $1 / 2 \mathrm{wt} \%$ may have large relative errors associated with them.

\subsubsection{EDXS and XRF Slag Analysis}

Slag compositions for all 1994 runs are presented in Tables 8.8 through 8.13 and are shown graphically for easy comparison in Figures 8.1 through 8.6. 
Table 8.8 EDX and XRF analysis of ARM082394 slag.

\begin{tabular}{|c|c|c|c|c|}
\hline Element & TOP-XRF & TOP-EDX & BOT-XRF & BOT-EDX \\
\hline $\mathrm{Na}$ & 0 & 9900 & 0 & 9600 \\
\hline $\mathrm{Mg}$ & 26400 & 10300 & 34300 & 10000 \\
\hline $\mathrm{Al}$ & 81200 & 50900 & 74000 & 51400 \\
\hline $\mathrm{Si}$ & 246000 & 193700 & 276000 & 195000 \\
\hline $\mathrm{K}$ & 19400 & 10700 & 25400 & 11100 \\
\hline $\mathrm{Ca}$ & 38300 & 29900 & 36300 & 30600 \\
\hline $\mathrm{Ti}$ & 24300 & 23900 & 30600 & 24000 \\
\hline $\mathrm{Cr}$ & 0 & 3200 & 0 & 3200 \\
\hline $\mathrm{Fe}$ & 152000 & 127000 & 126400 & 121000 \\
\hline $\mathrm{Zn}$ & 1600 & 0 & 1100 & 0 \\
\hline $\mathrm{Zr}$ & 15800 & 35500 & 15800 & 32900 \\
\hline $\mathrm{Cd}$ & 8 & 0 & 0 & 0 \\
\hline $\mathrm{Ce}$ & 483 & 2100 & 728 & 3400 \\
\hline $\mathrm{Cs}$ & 557 & 2100 & 8800 & 2400 \\
\hline $\mathrm{Sm}$ & 1900 & 1600 & 6900 & 0 \\
\hline $\mathrm{Pb}$ & 2400 & 0 & 2500 & 0 \\
\hline
\end{tabular}




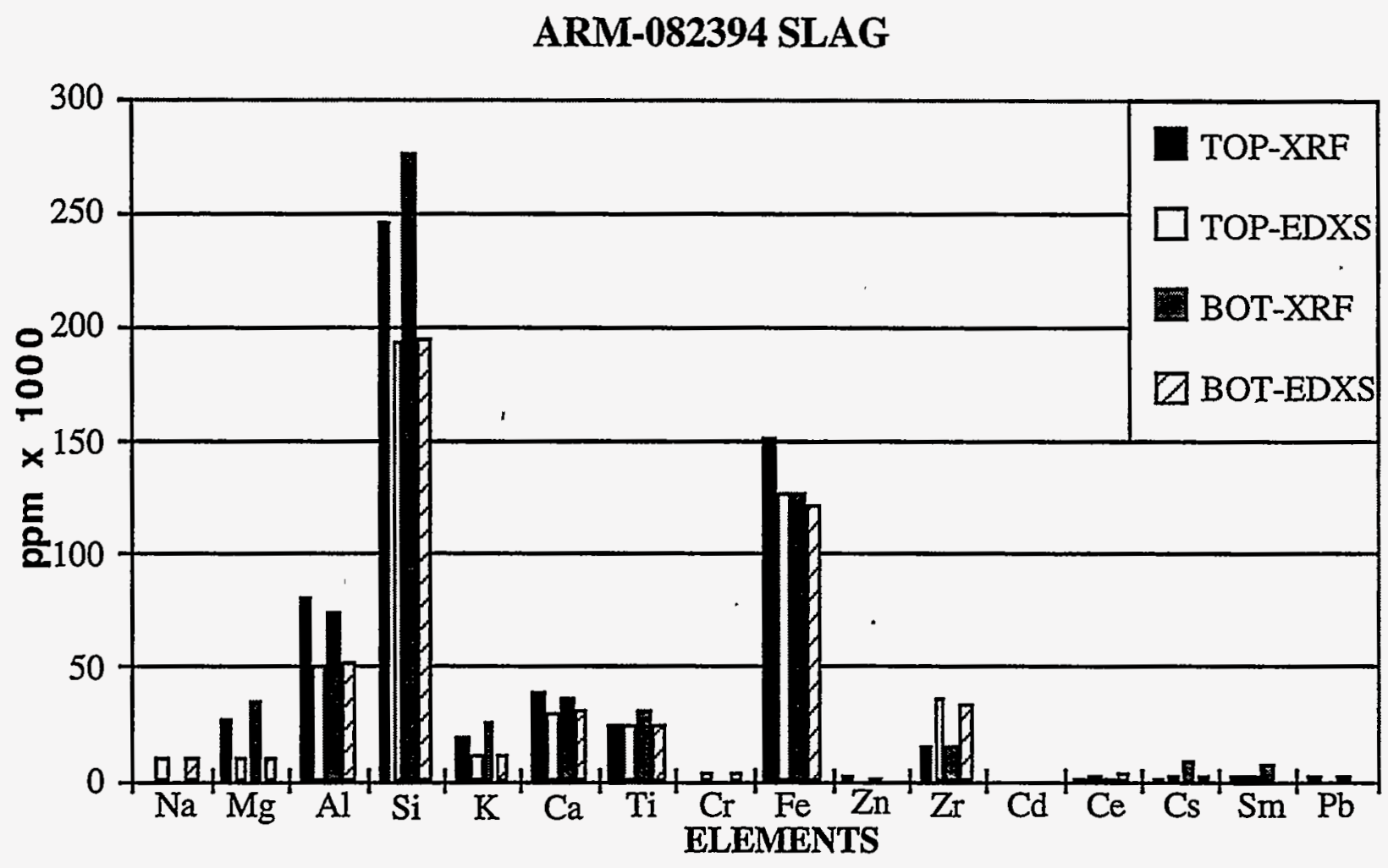

Figure 8.1 XRF and EDXS chemistry results from top and bottom samples of slag taken from run \#ARM082394. 
Table 8.9 EDX and XRF analysis of ARM-082694 slag.

\begin{tabular}{|c|c|c|c|c|}
\hline Element & TOP-XRF & TOP-EDXS & BOT-XRF & BOT-EDXS \\
\hline $\mathrm{Na}$ & 0 & 12300 & 0 & 10600 \\
\hline $\mathrm{Mg}$ & 28000 & 13100 & 27400 & 12300 \\
\hline $\mathrm{Al}$ & 65100 & 49700 & 57600 & 47600 \\
\hline $\mathrm{Si}$ & 246300 & 210800 & 218600 & 201600 \\
\hline $\mathrm{K}$ & 22100 & 12200 & 21200 & 11300 \\
\hline $\mathrm{Ca}$ & 37300 & 40200 & 38100 & 38800 \\
\hline $\mathrm{Ti}$ & 29100 & 26300 & 29400 & 25300 \\
\hline $\mathrm{Cr}$ & 0 & 3900 & 0 & 3700 \\
\hline $\mathrm{Fe}$ & 118000 & 120800 & 129400 & 123500 \\
\hline $\mathrm{Zn}$ & 2300 & 0 & 2100 & 0 \\
\hline $\mathrm{Zr}$ & 15400 & 101500 & 17000 & 108200 \\
\hline $\mathrm{Cd}$ & 215 & 0 & 79 & 0 \\
\hline $\mathrm{Ce}$ & 1600 & 4900 & 863 & 3200 \\
\hline $\mathrm{Cs}$ & 2300 & 3000 & 1100 & 3000 \\
\hline $\mathrm{Sm}$ & 7100 & 3700 & 7300 & 2400 \\
\hline $\mathrm{Pb}$ & 7000 & 0 & 6100 & 0 \\
\hline
\end{tabular}




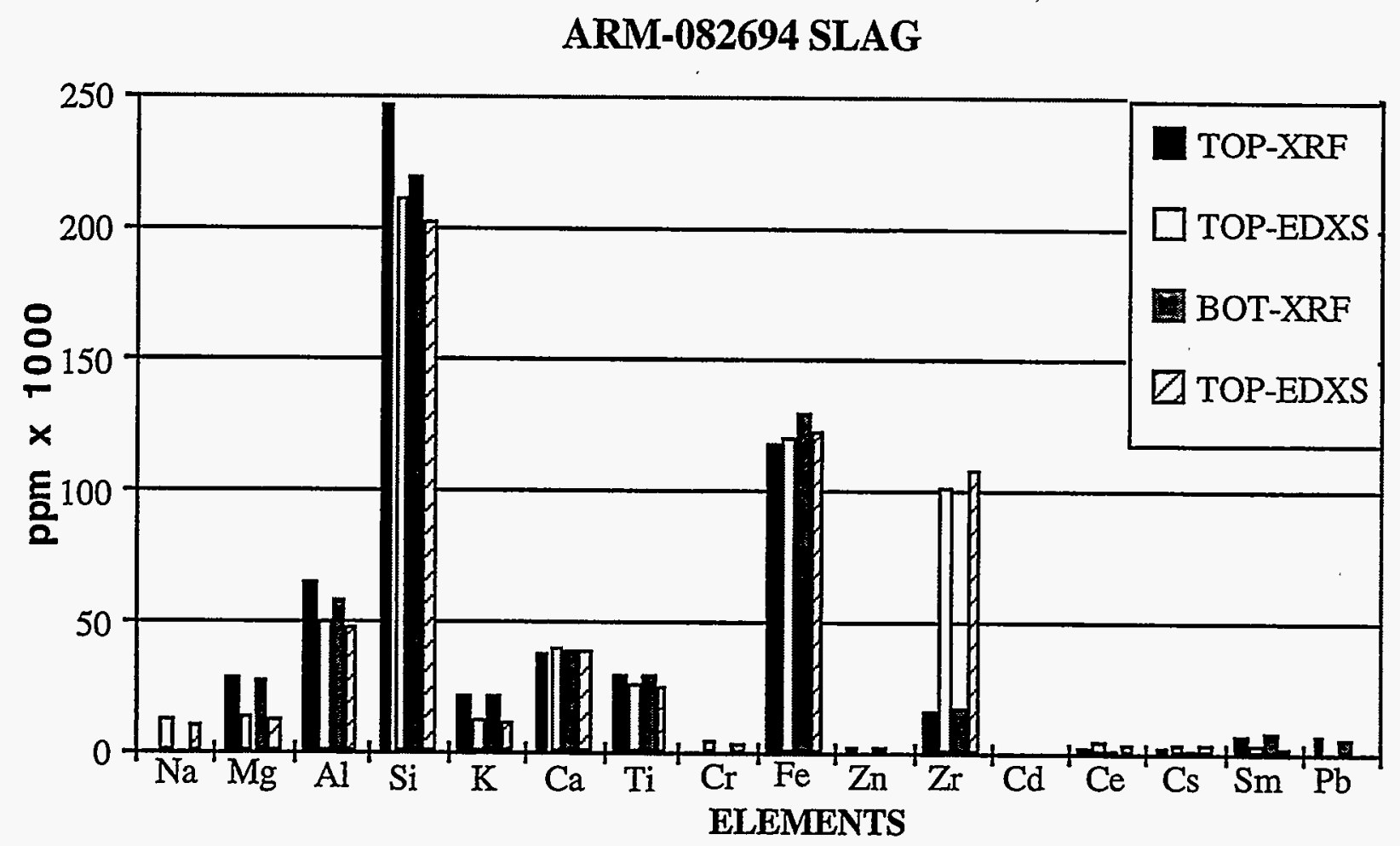

Figure 8.2 XRF and EDXS chemistry results from top and bottom samples of slag taken from run \#ARM082694. 
Table 8.10 EDX and XRF analysis of ARM-090694 slag.

\begin{tabular}{|c|c|c|c|c|}
\hline Element & TOP-XRF & TOP-EDXS & BOT-XRF & BOT-EDXS \\
\hline $\mathrm{Na}$ & 0 & 13200 & 0 & 15200 \\
\hline $\mathrm{Mg}$ & 32800 & 13000 & 48600 & 14600 \\
\hline $\mathrm{Al}$ & 57600 & 43900 & 48000 & 45400 \\
\hline $\mathrm{Si}$ & 57600 & 43900 & 222300 & 200000 \\
\hline $\mathrm{K}$ & 22800 & 11200 & 14800 & 11900 \\
\hline $\mathrm{Ca}$ & 45500 & 42600 & 37000 & 42400 \\
\hline $\mathrm{Ti}$ & 34600 & 27000 & 24700 & 27100 \\
\hline $\mathrm{Cr}$ & 0 & 2200 & 0 & 3100 \\
\hline $\mathrm{Fe}$ & 150000 & 147400 & 126900 & 151800 \\
\hline $\mathrm{Zn}$ & 2100 & 0 & 1700 & 0 \\
\hline $\mathrm{Zr}$ & 14400 & 73100 & 13600 & 62900 \\
\hline $\mathrm{Cd}$ & 45 & 0 & 32 & 0 \\
\hline $\mathrm{Ce}$ & 1400 & 4300 & 1300 & 2400 \\
\hline $\mathrm{Cs}$ & 1400 & 2100 & 1300 & 2300 \\
\hline $\mathrm{Sm}$ & 6800 & 0 & .5300 & 1900 \\
\hline $\mathrm{Pb}$ & 2500 & 0 & 2000 & 0 \\
\hline
\end{tabular}




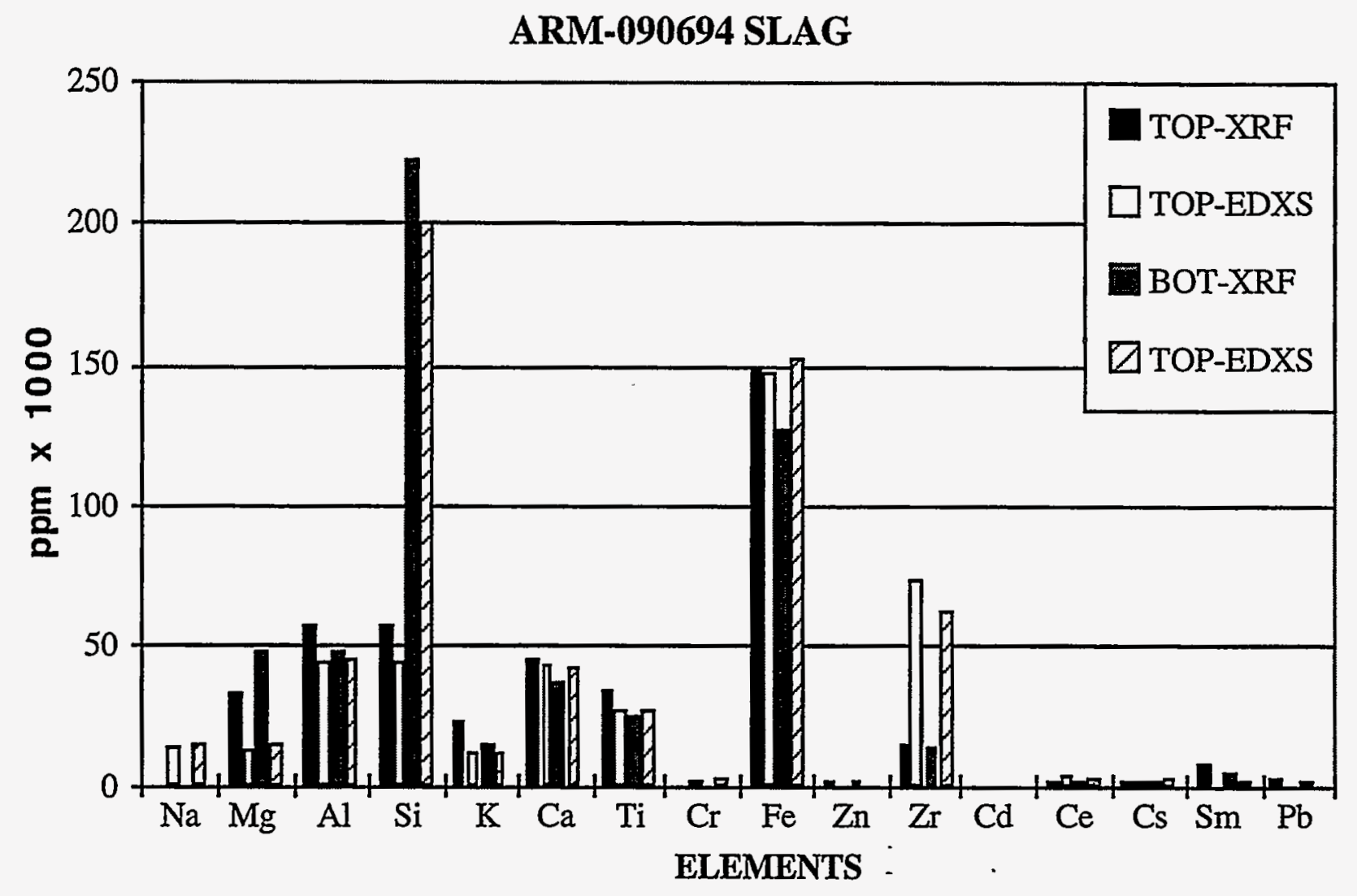

Figure 8.3 XRF and EDXS chemistry results from top and bottom samples of slag taken from run \#ARM090694. 
Table 8.11 EDX and XRF analysis of ARM-090894 slag.

\begin{tabular}{|c|c|c|c|c|}
\hline Element & TOP-XRF & TOP-EDXS & BOT-XRF & BOT-EDXS \\
\hline $\mathrm{Na}$ & 0 & 14400 & 0 & 13900 \\
\hline $\mathrm{Mg}$ & 26600 & 14900 & 34500 & 14800 \\
\hline $\mathrm{Al}$ & 57200 & 47800 & 61000 & 47300 \\
\hline $\mathrm{Si}$ & 265700 & 202300 & 263900 & 199300 \\
\hline $\mathrm{K}$ & 20900 & 12700 & 23900 & 12200 \\
\hline $\mathrm{Ca}$ & 41600 & 43400 & 45200 & 42900 \\
\hline $\mathrm{Ti}$ & 30900 & 27500 & 34600 & 27800 \\
\hline $\mathrm{Cr}$ & 0 & 3200 & 0 & 2100 \\
\hline $\mathrm{Fe}$ & 128700 & 131600 & 143000 & 133200 \\
\hline $\mathrm{Zn}$ & 1800 & 0 & 2000 & 0 \\
\hline $\mathrm{Zr}$ & 16100 & 82300 & 17400 & 81800 \\
\hline $\mathrm{Cd}$ & 19 & 0 & 20 & 0 \\
\hline $\mathrm{Ce}$ & 1400 & 4700 & 1300 & 2300 \\
\hline $\mathrm{Cs}$ & 1700 & 3400 & 1700 & 3100 \\
\hline $\mathrm{Sm}$ & 6800 & 2900 & 7600 & 0 \\
\hline $\mathrm{Pb}$ & 2700 & 0 & 2900 & 0 \\
\hline
\end{tabular}




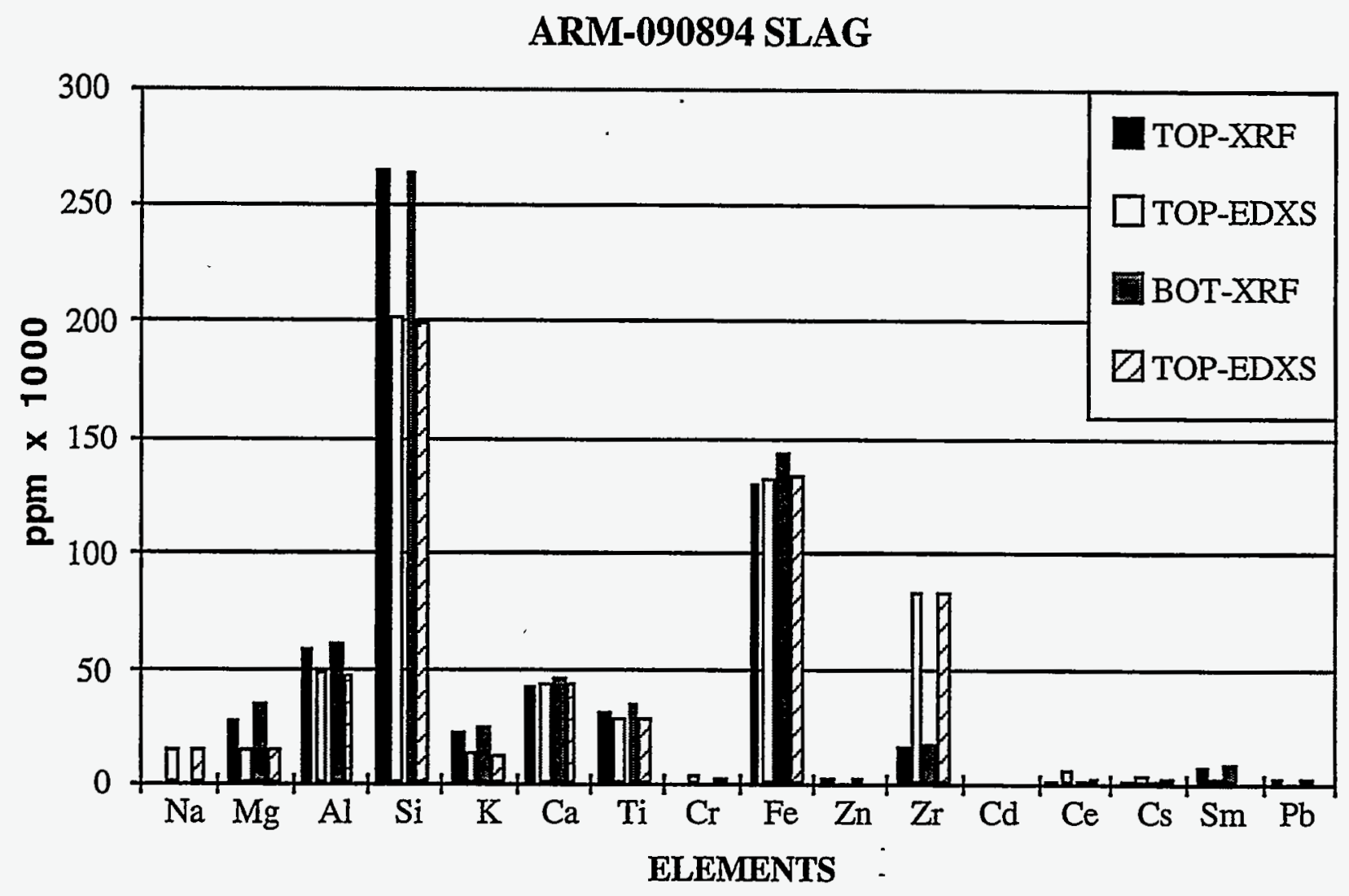

Figure 8.4 XRF and EDXS chemistry results from top and bottom samples of slag taken from run \#ARM090894. 
Table 8.12 EDX analysis of ARM-092094 slag.

\begin{tabular}{|c|c|c|}
\hline Element & TOP-EDXS & BOT-EDXS \\
\hline $\mathrm{Na}$ & 11700 & 13600 \\
\hline $\mathrm{Mg}$ & 14900 & 15300 \\
\hline $\mathrm{Al}$ & 46200 & 48200 \\
\hline $\mathrm{Si}$ & 194100 & 201100 \\
\hline $\mathrm{K}$ & 11000 & 9900 \\
\hline $\mathrm{Ca}$ & 46500 & 46600 \\
\hline $\mathrm{Ti}$ & 25700 & 25900 \\
\hline $\mathrm{Cr}$ & 1900 & 2200 \\
\hline $\mathrm{Fe}$ & 124800 & 123300 \\
\hline $\mathrm{Zn}$ & 0 & 0 \\
\hline $\mathrm{Zr}$ & 84500 & 89000 \\
\hline $\mathrm{Cd}$ & 0 & 0 \\
\hline $\mathrm{Ce}$ & 2600 & 4400 \\
\hline $\mathrm{Cs}$ & 2700 & 2200 \\
\hline $\mathrm{Sm}$ & 1500 & 1800 \\
\hline $\mathrm{Pb}$ & 0 & 0 \\
\hline
\end{tabular}




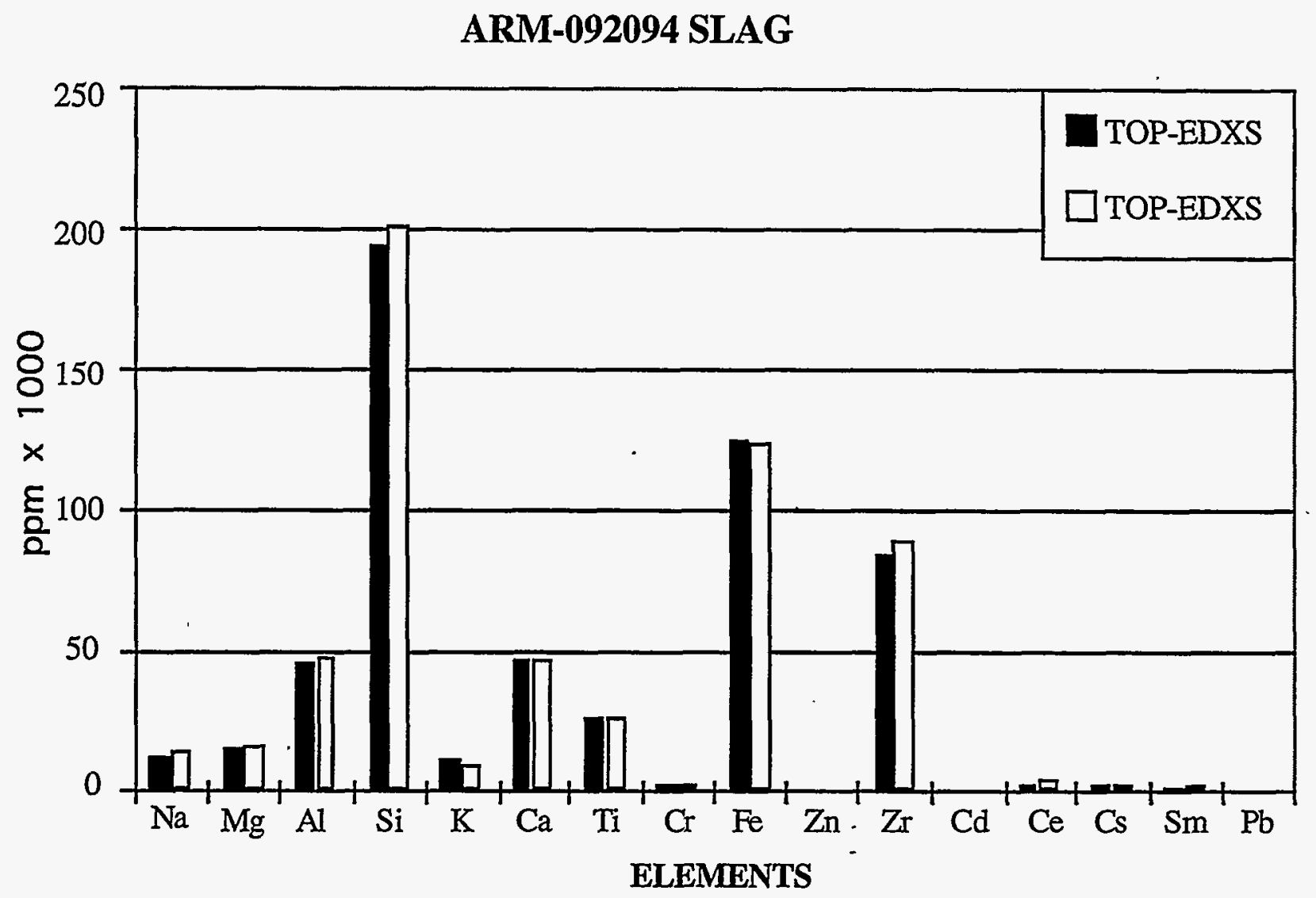

Figure 8.5 EDXS chemistry results from top and bottom samples of slag taken from run \#ARM092094. 
Table 8.13 EDX Analysis of ARM-092294 Slag.

\begin{tabular}{|c|c|c|}
\hline Element & TOP-EDXS & BOT-EDXS \\
\hline $\mathrm{Na}$ & 10300 & 13900 \\
\hline $\mathrm{Mg}$ & 15100 & 15400 \\
\hline $\mathrm{Al}$ & 49500 & 37500 \\
\hline $\mathrm{Si}$ & 212500 & 138000 \\
\hline $\mathrm{K}$ & 13000 & 4700 \\
\hline $\mathrm{Ca}$ & 50500 & 19000 \\
\hline $\mathrm{Ti}$ & 28200 & 8000 \\
\hline $\mathrm{Cr}$ & 3700 & 40910 \\
\hline $\mathrm{Fe}$ & 109200 & 37500 \\
\hline $\mathrm{Zn}$ & 0 & 0 \\
\hline $\mathrm{Zr}$ & 88300 & 14600 \\
\hline $\mathrm{Cd}$ & 0 & 0 \\
\hline $\mathrm{Ce}$ & 3000 & 1000 \\
\hline $\mathrm{Cs}$ & 3400 & 500 \\
\hline $\mathrm{Sm}$ & 4100 & 4800 \\
\hline $\mathrm{Pb}$ & 0 & 0 \\
\hline
\end{tabular}




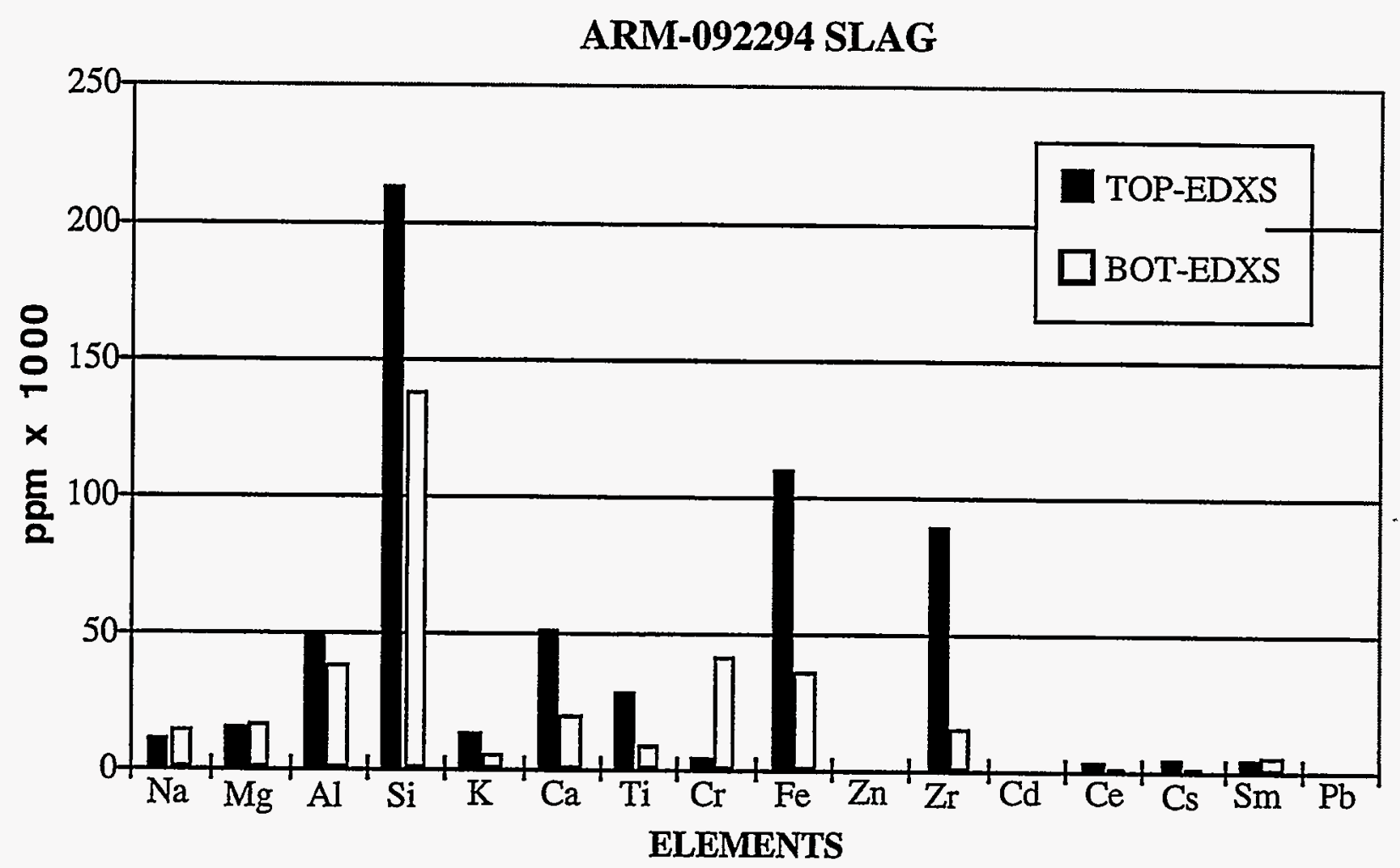

Figure 8.6 EDXS chemistry results from top and bottom samples of slag taken from run \#ARM092294. 


\subsubsection{ICP and FLAA Slag Analysis}

The ICP spectrochemical analysis of the slags for the HVPMs and surrogates for each experiment is presented in Table 8.14. FLAA spectroscopy was used only to determine cerium concentrations. Results in Table 8.14 are averaged, and the full analysis for these and the other elements can be found in Appendix F.

The ICP analysis of the slags which consists of first digesting the material to be analyzed was expected to show greater concentrations of samarium, cerium, and chromium in the slag since relatively smaller amounts of these elements were found in the particulate entrained in the off-gas as compared to the rest of HVPMs and surrogates. Data in Table 8.15, however, indicates relatively small amounts of $\mathrm{Sm}, \mathrm{Ce}$, and $\mathrm{Cr}$, and is consistent with the EDXS and XRF analyses. As will be seen in section 8.7, the mass balance for these elements is very poor, with far less material accounted for than originally added to the melt. On the other hand, the volatile HVPMs (cadmium, lead, and zinc) show a marked decrease in concentration in the slag, which is commensurate with the high concentrations found in the off-gas particulates.

Table 8.14 ICP analysis - Average concentrations for HVPMs and surrogates in the slag.

\begin{tabular}{|c|c|c|c|c|c|c|}
\hline Element & $\begin{array}{c}\text { ARM } \\
082394 \\
(\mathrm{ppm})\end{array}$ & $\begin{array}{c}\text { ARM } \\
082694 \\
(\mathrm{ppm})\end{array}$ & $\begin{array}{c}\text { ARM } \\
090694 \\
(\mathrm{ppm})\end{array}$ & $\begin{array}{c}\text { ARM } \\
090894 \\
(\mathrm{ppm})\end{array}$ & $\begin{array}{c}\text { ARM } \\
092094 \\
(\mathrm{ppm})\end{array}$ & $\begin{array}{c}\text { ARM } \\
092294 \\
(\mathrm{ppm})\end{array}$ \\
\hline $\mathrm{Cr}$ & 3557 & 3301 & 1599 & 2258 & 3257 & 3404 \\
\hline $\mathrm{Zn}$ & 2113 & 8976 & 6076 & 2165 & 3097 & 1002 \\
\hline $\mathrm{Cd}$ & 1832 & 1086 & 222 & 111 & 1289 & 91 \\
\hline $\mathrm{Cs}$ & 5082 & 2732 & 3216 & 5060 & 4325 & 5319 \\
\hline $\mathrm{Ce}$ & 2514 & 1139 & 1251 & 2038 & 1145 & 1020 \\
\hline $\mathrm{Sm}$ & 1154 & 167 & 794 & 1041 & 331 & 659 \\
\hline $\mathrm{Pb}$ & 2808 & 6128 & 2126 & 2385 & 3181 & 870 \\
\hline
\end{tabular}




\subsection{Detailed Mass Balance for HVPMs and Surrogates}

With the concentrations of HVPMs and surrogates in the slag and particulates identified, a detailed mass balance for each element can be formulated. As a first step, Table 8.15 gives the elemental composition of the starting material, IEB4/A-40 with HVPMs and surrogates added. Using this table, the total amount (grams) of any element can be calculated by knowing the total amount of IEB4/A-40 used in the melt. Since the chemical analyses indicate only the metals amounts and not oxide forms, Table 8.15 also contains the metals basis wt $\%$ and parts per million for each metals constituent.

Table 8.16 contains the necessary information to complete the mass balances. The information is similar to that contained in Table 8.3, but has been rearranged and grouped differently. Column two contains the total amount of IEB4/A-40 added during the experiment. The total mass (column three Table 8.16) is simply the sum of IEB4/A-40 mass plus the mass of the iron starting ring. The total solids mass measured after the experiment is the sum of the next three columns, which includes the slag mass and the particulate collected within the arc melter system. The chamber mass (column 5 ) is the sum of masses listed under liner extension and lid in Table 8.3. This is total particulate collected in the melt chamber just above the slag. The remaining particulates collected in the exhaust system equal the sum of material collected in the exhaust lines, filters, and cyclone.

\subsubsection{Detailed Mass Balances for HVPMs}

Using the information on concentrations of HVPMs in the slag and particulates found in Sections 8.5 and 8.6, and the information in Table 8.16 listing the mass amounts of slag and particulates, a detailed mass balance can be calculated. Table 8.17 lists the wt $\%$ of each constituent HVPM found in the slag and particulates as determined by EDX and XRF analysis and in the next column the mass amount of that constituent. In the second to the last column, the masses are added together yielding the total amount of each HVPM found in the slag and particulates. This can be compared with the total mass amount of each HVPM originally introduced into the IEB4/A-40. EDX or XRF spectroscopic analyses were not performed for ARM092094 and ARM092294. While the mass balance for chromium cannot be calculated since the particulates were not analyzed for that element, the results for the remaining HVPMs in general do not account for all the HVPMs. Averaging over results of the four tests, lead shows the best mass balance at $89 \%$, while zinc and cadmium average only $76 \%$ and $64 \%$, respectively. 
Table 8.15 IEB4/A-40, HVPMs, and surrogates composition for the FY-94 tests.

\begin{tabular}{|c|c|c|c|c|}
\hline $\begin{array}{c}\text { Oxide } \\
\text { component }\end{array}$ & $\begin{array}{c}\text { Calculated } \\
\text { oxide values } \\
\text { (wt\%) }\end{array}$ & $\begin{array}{c}\text { Calculated } \\
\text { oxide values } \\
\text { (ppm) }\end{array}$ & $\begin{array}{c}\text { Metals } \\
\text { basis values } \\
\text { (wt\%) }\end{array}$ & $\begin{array}{c}\text { Metals } \\
\text { basis values } \\
\text { (ppm) }\end{array}$ \\
\hline $\mathrm{Na2O}$ & 2.678 & 26780 & 1.987 & 19870 \\
\hline $\mathrm{MgO}$ & 2.930 & 29300 & 1.767 & 17670 \\
\hline $\mathrm{Al}_{2} \mathrm{O}_{3}$ & 8.537 & 85370 & 4.520 & 45200 \\
\hline $\mathrm{SiO}_{2}$ & 42.603 & 426030 & 19.881 & 198810 \\
\hline $\mathrm{K}_{2} \mathrm{O}$ & 2.176 & 21760 & 1.806 & 18060 \\
\hline $\mathrm{CaO}$ & 8.119 & 81190 & 5.803 & 58030 \\
\hline $\mathrm{TiO}_{2}$ & 4.902 & 49020 & 2.939 & 29390 \\
\hline $\mathrm{Cr}_{2} \mathrm{O}_{3}$ & 1.000 & 10000 & 0.684 & 6840 \\
\hline $\mathrm{Fe}_{2} \mathrm{O}_{3}$ & 16.405 & 164050 & 11.747 & 11747 \\
\hline $\mathrm{ZnO}$ & 1.000 & 10000 & 0.803 & 8030 \\
\hline $\mathrm{ZrO}_{2}$ & 4.650 & 46500 & 3.442 & 34420 \\
\hline $\mathrm{CdO}$ & 1.000 & 10000 & 0.875 & 8750 \\
\hline $\mathrm{Cs}_{2} \mathrm{CO}_{3}$ & 1.000 & 10000 & 0.820 & 8200 \\
\hline $\mathrm{CeO}_{2}$ & 1.000 & 10000 & 0.814 & 8140 \\
\hline $\mathrm{Sm}_{2} \mathrm{O}_{3}$ & 1.000 & 10000 & 0.862 & 8620 \\
\hline $\mathrm{PbO}$ & 1.000 & 10000 & 0.928 & \\
\hline
\end{tabular}




\section{IEB4/A-40 COMPOSITION}

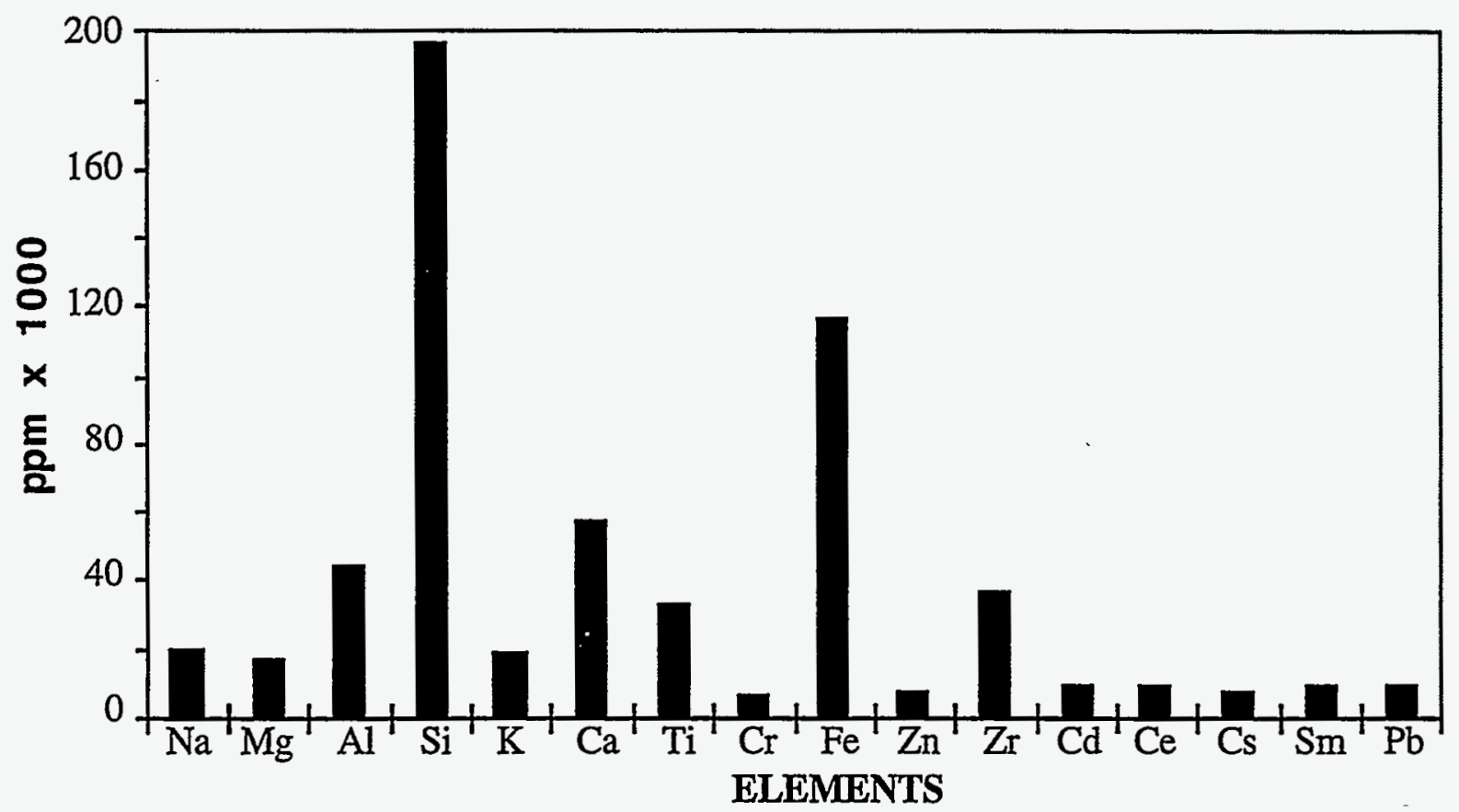

Figure 8.7 Calculated composition of the starting IEB4/A-40 waste-soil mixture. 
Table 8.16 Mass balance information for solid materials in the arc melter system.

\begin{tabular}{|c|c|c|c|c|c|c|}
\hline Experiment & $\begin{array}{c}\text { IEB4/A-40 } \\
\text { mass } \\
(\mathrm{kg})\end{array}$ & $\begin{array}{c}\text { Total } \\
\text { mass } \\
(\mathrm{kg})\end{array}$ & $\begin{array}{c}\text { Slag } \\
\text { mass } \\
(\mathrm{kg})\end{array}$ & $\begin{array}{c}\text { Chamber } \\
\text { mass } \\
(\mathrm{kg})\end{array}$ & $\begin{array}{c}\text { Exhaust } \\
\text { mass } \\
(\mathrm{kg})\end{array}$ & $\begin{array}{c}\text { Diff } \\
(\mathrm{kg})\end{array}$ \\
\hline ARM082394 & 3.007 & 3.431 & 2.920 & 0.068 & 0.042 & 0.401 \\
\hline ARM082694 & 4.730 & 5.150 & 4.450 & 0.076 & 0.050 & 0.574 \\
\hline ARM090694 & 4.450 & 4.925 & 4.245 & 0.033 & 0.069 & 0.440 \\
\hline ARM090894 & 4.803 & 5.230 & 4.530 & 0.041 & 0.064 & 0.595 \\
\hline ARM092094 & 5.563 & 5.936 & 4.858 & 0.040 & 0.050 & 0.988 \\
\hline ARM092294 & 5.156 & 5.493 & 4.686 & 0.067 & 0.078 & 0.662 \\
\hline
\end{tabular}

Slag and particulate samples were also analyzed using ICP spectroscopy by an independent source. Table 8.18 contains the results for the HVPMs. These results are similar to those of the EDX and XRF analysis in that generally the amounts of each element found in the slag and particulates are lower than the amount initially introduced, although in some instances the amount is greater. The amount of chromium found in the slag and particulates is consistently much lower than the amount introduced. Over the six experiments, the average mass balance for chromium is just $40 \%$. The other HVPMs show much better recovery, averaging $83 \%$ for zinc, $67 \%$ for cadmium and $79 \%$ for lead, however, there are extreme fluctuations in the data. For instance for lead, the mass balance for ARM082694 is 134\%, while the mass balance for ARM092094 is only $57 \%$.

\subsubsection{Detailed Mass Balances for Radionuclide Surrogates.}

The mass balance closure for the surrogate elements is more worrisome than for the HVPMs. Table 8.19 shows both the EDX and ICP analytical results for ARM082394. Both data sets are extremely consistent, and the data in Table 8.19 are representative of any of the other experiments. The mass balance closure for cesium is close to $60 \%$, which is similar to the HVPMs (Cs is also very volatile). The closure for cerium and samarium is only within the range of $20-30 \%$, even less than that of chromium. It is notable that for the surrogate elements, there is consistency between the X-ray analytical methods (EDX and XRF) and the wet chemical analysis (ICP and FLAA). 
Table 8.17a HVPM mass balance using EDXS and XRF spectroscopic analysis.

\begin{tabular}{|c|c|c|c|c|c|c|c|c|}
\hline Element & $\begin{array}{c}\text { Slag } \\
(\mathrm{wt} \%)\end{array}$ & $\begin{array}{c}\text { Slag } \\
\text { mass } \\
(\mathrm{g}) \\
\end{array}$ & $\begin{array}{c}\text { Chamber } \\
\text { particulate } \\
\text { mass } \\
(w t \%) \\
\end{array}$ & $\begin{array}{c}\text { Chamber } \\
\text { particulate } \\
\text { mass } \\
(\mathrm{g})\end{array}$ & $\begin{array}{c}\text { Exhaust } \\
\text { filter } \\
\text { particulate } \\
\text { (wt\%) }\end{array}$ & $\begin{array}{c}\text { Filter } \\
\text { particulate } \\
\text { mass } \\
\text { (g) }\end{array}$ & $\begin{array}{c}\text { Total } \\
\text { mass } \\
(\mathrm{g})\end{array}$ & $\begin{array}{l}\text { Introduced } \\
\text { mass } \\
(\mathrm{g})\end{array}$ \\
\hline \multicolumn{9}{|c|}{ ARM082394 } \\
\hline $\mathrm{Cr}$ & 0.32 & 11.7 & - & & - & & & 25.7 \\
\hline $\mathrm{Zn}$ & 0.14 & 5.1 & 15.56 & 13.3 & 18.79 & 7.9 & 23.6 & 30.2 \\
\hline $\mathrm{Cd}$ & 0.00 & 0.0 & 31.30 & 27.2 & 16.36 & 6.9 & 28.2 & 32.9 \\
\hline $\mathrm{Pb}$ & 0.25 & 9.2 & 23.04 & 15.2 & 16.79 & 7.1 & 32.0 & 34.9 \\
\hline \multicolumn{9}{|c|}{ ARM082694 } \\
\hline $\mathrm{Cr}$ & 0.38 & 22.6 & - & & - & & & 42.6 \\
\hline $\mathrm{Zn}$ & 0.22 & 13.1 & 17.56 & 13.3 & 14.21 & 7.1 & 33.5 & 50.0 \\
\hline $\mathrm{Cd}$ & 0.02 & 1.2 & 35.84 & 27.2 & 12.92 & 6.5 & 34.9 & 54.5 \\
\hline $\mathrm{Pb}$ & 0.66 & 39.3 & 19.95 & 15.2 & 16.53 & 8.3 & 62.8 & 57.8 \\
\hline \multicolumn{9}{|c|}{ ARM090694 } \\
\hline $\mathrm{Cr}$ & 0.27 & 15.9 & - & & 0.38 & 22.6 & & 40.7 \\
\hline $\mathrm{Zn}$ & 0.19 & 11.2 & 19.00 & 6.3 & 16.34 & 11.3 & 28.8 & 47.8 \\
\hline $\mathrm{Cd}$ & 0.00 & 0.0 & 37.83 & 12.5 & 22.40 & 15.5 & 28.0 & 52.1 \\
\hline $\mathrm{Pb}$ & 0.23 & 13.5 & 21.99 & 7.3 & 20.80 & 14.4 & 35.2 & 55.2 \\
\hline
\end{tabular}


Table 8.17b HVPM mass balance using EDXS and XRF spectroscopic analysis.

\begin{tabular}{|c|c|c|c|c|c|c|c|c|}
\hline Element & $\begin{array}{c}\text { Slag } \\
(w t \%)\end{array}$ & $\begin{array}{c}\text { Slag } \\
\text { mass } \\
(\mathrm{g})\end{array}$ & $\begin{array}{c}\text { Chamber } \\
\text { particulate } \\
\text { mass } \\
(w t \%)\end{array}$ & $\begin{array}{l}\text { Chamber } \\
\text { particulate } \\
\text { Mass } \\
\text { (g) }\end{array}$ & $\begin{array}{c}\text { Exhaust } \\
\text { filter } \\
\text { particulate } \\
(w t \%)\end{array}$ & $\begin{array}{c}\text { Filter } \\
\text { particulate } \\
\text { mass } \\
(\mathrm{g})\end{array}$ & $\begin{array}{c}\text { Total } \\
\text { Mass } \\
\text { (g) }\end{array}$ & $\begin{array}{l}\text { Introduced } \\
\text { Mass } \\
\text { (g) }\end{array}$ \\
\hline \multicolumn{9}{|c|}{ ARM090894 } \\
\hline $\mathrm{Cr}$ & 0.27 & 16.3 & - & & 0.18 & 10.7 & & 43.1 \\
\hline $\mathrm{Zn}$ & 0.19 & 11.5 & 16.17 & 6.6 & 18.77 & 12.0 & 30.1 & 31.0 \\
\hline $\mathrm{Cd}$ & 0.00 & 0.0 & 16.62 & 6.8 & 15.51 & 9.9 & 16.7 & 32.0 \\
\hline $\mathrm{Pb}$ & 0.28 & 16.9 & 16.17 & 6.6 & 13.87 & 8.9 & 32.4 & 34.9 \\
\hline
\end{tabular}


Table 8.18a HVPM mass balance using ICP spectroscopic analysis.

\begin{tabular}{|c|c|c|c|c|c|c|c|c|}
\hline Element & $\begin{array}{c}\text { Slag } \\
(\mathrm{wt} \%)\end{array}$ & $\begin{array}{c}\text { Slag } \\
\text { Mass } \\
\text { (g) }\end{array}$ & $\begin{array}{c}\text { Chamber } \\
\text { Particulate } \\
(w t \%)\end{array}$ & $\begin{array}{c}\text { Chamber } \\
\text { Particulate } \\
\text { Mass } \\
\text { (g) }\end{array}$ & $\begin{array}{l}\text { Exhaust } \\
\text { Filter } \\
\text { Particulate } \\
\text { (wt\%) }\end{array}$ & $\begin{array}{l}\text { Filter } \\
\text { Particulate } \\
\text { Mass } \\
\text { (g) }\end{array}$ & $\begin{array}{c}\text { Total } \\
\text { Mass } \\
\text { (g) }\end{array}$ & $\begin{array}{l}\text { Introduced } \\
\text { Mass } \\
\text { (g) }\end{array}$ \\
\hline \multicolumn{9}{|c|}{ ARM082394 } \\
\hline $\mathrm{Cr}$ & 0.36 & 10.4 & 0.11 & 0.1 & 0.13 & 0.1 & 10.6 & 20.6 \\
\hline $\mathrm{Zn}$ & 0.21 & 6.2 & 12.39 & 8.4 & 7.90 & 3.3 & 17.9 & 24.1 \\
\hline $\mathrm{Cd}$ & 0.18 & 5.3 & 26.28 & 17.9 & 9.99 & 4.2 & 27.4 & 26.3 \\
\hline $\mathrm{Pb}$ & 0.28 & 8.2 & 23.88 & 16.2 & 13.63 & 5.7 & 30.1 & 27.9 \\
\hline \multicolumn{9}{|c|}{ ARM082694 } \\
\hline $\mathrm{Cr}$ & 0.33 & 14.7 & 0.13 & 0.1 & 0.22 & 0.1 & 14.9 & 32.4 \\
\hline $\mathrm{Zn}$ & 0.90 & 38.6 & 9.58 & 7.3 & 10.08 & 5.0 & 50.9 & 38.0 \\
\hline $\mathrm{Cd}$ & 0.11 & 4.8 & 24.32 & 18.5 & 12.78 & 6.4 & 29.7 & 41.4 \\
\hline $\mathrm{Pb}$ & 0.61 & 27.3 & 28.50 & 21.7 & 16.48 & 8.3 & $57.3^{\circ}$ & 43.9 \\
\hline \multicolumn{9}{|c|}{ ARM090694 } \\
\hline $\mathrm{Cr}$ & 0.16 & 6.8 & 0.32 & 0.1 & 0.21 & 0.1 & 7.0 & 30.4 \\
\hline $\mathrm{Zn}$ & 0.61 & 25.8 & 10.82 & 3.6 & 10.06 & 6.9 & 36.3 & $35: 7$ \\
\hline $\mathrm{Cd}$ & 0.02 & 0.9 & 24.07 & 7.9 & 14.24 & 9.8 & 18.6 & $38: 9$ \\
\hline $\mathrm{Pb}$ & 0.21 & 9.0 & 16.27 & 5.4 & 13.22 & 9.1 & 23.5 & 41.3 \\
\hline
\end{tabular}


Table $8.18 \mathrm{~b}$ HVPM mass balance using ICP spectroscopic analysis.

\begin{tabular}{|c|c|c|c|c|c|c|c|c|}
\hline Element & $\begin{array}{c}\text { Slag } \\
(w t \%)\end{array}$ & $\begin{array}{c}\text { Slag } \\
\text { Mass } \\
(\mathrm{g})\end{array}$ & $\begin{array}{c}\text { Chamber } \\
\text { Particulate } \\
(w t \%)\end{array}$ & $\begin{array}{l}\text { Chamber } \\
\text { Particulate } \\
\text { Mass } \\
\text { (g) }\end{array}$ & $\begin{array}{l}\text { Exhaust } \\
\text { Filter } \\
\text { Particulate } \\
\text { (wt \%) }\end{array}$ & $\begin{array}{c}\text { Filter } \\
\text { Particulate } \\
\text { Mass } \\
\text { (g) }\end{array}$ & $\begin{array}{c}\text { Total } \\
\text { Mass } \\
(\mathrm{g})\end{array}$ & $\begin{array}{c}\text { Introduced } \\
\text { Mass } \\
\text { (g) }\end{array}$ \\
\hline \multicolumn{9}{|c|}{ ARM090̣894 } \\
\hline $\mathrm{Cr}$ & 0.23 & 10.3 & 0.29 & 0.1 & 0.22 & 0.1 & 10.5 & 32.8 \\
\hline $\mathrm{Zn}$ & 0.22 & 9.8 & 10.48 & 4.3 & 14.24 & 9.1 & 23.2 & 38.6 \\
\hline $\mathrm{Cd}$ & 0.01 & 0.5 & 24.64 & 10.1 & 16.84 & 10.8 & 21.4 & 42.0 \\
\hline $\mathrm{Pb}$ & 0.24 & 10.8 & 14.89 & 6.1 & 14.66 & 9.4 & 26.3 & 44.6 \\
\hline \multicolumn{9}{|c|}{ ARM092094 } \\
\hline $\mathrm{Cr}$ & 0.33 & 15.8 & 0.33 & 0.1 & 0.20 & 0.1 & 16.0 & 38.1 \\
\hline $\mathrm{Zn}$ & 0.31 & 15.0 & 13.84 & 5.5 & 12.38 & 6.2 & 26.7 & 44.7 \\
\hline $\mathrm{Cd}$ & 0.13 & 6.3 & 27.98 & 11.2 & 21.44 & 10.7 & 28.2 & 48.7 \\
\hline $\mathrm{Pb}$ & 0.32 & 14.9 & 17.68 & 7.1 & 14.71 & 7.4 & 29.4 & 51.6 \\
\hline \multicolumn{9}{|c|}{ ARM092294 } \\
\hline $\mathrm{Cr}$ & 0.34 & 16.0 & 0.23 & 0.2 & 0.16 & 0.1 & 16.3 & 35.2 \\
\hline $\mathrm{Zn}$ & 0.10 & 4.7 & 15.73 & 10.5 & 15.90 & 12.4 & 27.8 & 41.4 \\
\hline $\mathrm{Cd}$ & 0.01 & 0.4 & 23.83 & 16.0 & 19.75 & 15.4 & 31.8 & 45.1 \\
\hline $\mathrm{Pb}$ & 0.08 & 4.1 & 17.90 & 12.0 & 17.33 & 13.5 & 29.6 & 47.8 \\
\hline
\end{tabular}


Table 8.19 Surrogate mass balance for ARM082394.

\begin{tabular}{|c|c|c|c|c|c|c|c|c|}
\hline Element & $\begin{array}{c}\text { Slag } \\
\text { (wt\%) }\end{array}$ & $\begin{array}{l}\text { Slag } \\
\text { Mass } \\
(\mathrm{g})\end{array}$ & $\begin{array}{c}\text { Chamber } \\
\text { Particulate } \\
\text { (wt\%). }\end{array}$ & $\begin{array}{l}\text { Chamber } \\
\text { Particulate } \\
\text { Mass } \\
\text { (g) }\end{array}$ & $\begin{array}{c}\text { Exhaust } \\
\text { Filter } \\
\text { Particulate } \\
\text { (wt\%) }\end{array}$ & $\begin{array}{c}\text { Filter } \\
\text { Particulate } \\
\text { Mass } \\
\text { (g) }\end{array}$ & $\begin{array}{l}\text { Total } \\
\text { Mass } \\
(\mathrm{g})\end{array}$ & $\begin{array}{c}\text { Introduced } \\
\text { Mass } \\
\text { (g) }\end{array}$ \\
\hline \multicolumn{9}{|c|}{ ARM082394 - EDX \& XRF } \\
\hline Cs & 0.35 & 12.8 & 1.80 & 1.2 & 7.29 & 3.1 & 17.1 & 24.7 \\
\hline $\mathrm{Ce}$ & 0.17 & 6.3 & 0.76 & 0.5 & 0.09 & 0.1 & 6.9 & 24.5 \\
\hline $\mathrm{Sm}$ & 0.26 & 9.5 & 0.99 & 0.8 & 0.14 & 0.1 & 10.4 & 25.9 \\
\hline \multicolumn{9}{|c|}{ ARM082394 - ICP \& FLAA } \\
\hline Cs & 0.51 & 14.8 & 3.47 & 2.4 & 2.14 & 1.0 & 18.2 & 24.7 \\
\hline $\mathrm{Ce}$ & 0.25 & 7.3 & 0.45 & 0.3 & 0.05 & 0.0 & 7.6 & 24.5 \\
\hline $\mathrm{Sm}$ & 0.12 & 4.5 & 0.60 & 0.4 & 0.02 & 0.0 & 4.9 & 25.9 \\
\hline
\end{tabular}




\subsection{Discussion}

The mass balance closures for both the HVPM and surrogate elements are low. Reasons for this are not entirely clear, particularly since separate analytical methods were employed and are generally consistent with each other. The largest possibility for error is in the slag analysis since the concentrations of the subject elements are quite low (less than $1 \mathrm{wt} \%$ ). The relative error for low-concentration measurements is probably higher than for high-concentration measurements. This is compounded by the fact that the slag constitutes by far the largest mass amount of melter residues. Therefore, even modest errors in the slag concentrations could cause large deviations in the mass balance closure. There are other possible reasons. The varied mass closure results of lead (57\% to $134 \%$ ) might suggest the partitioning of elements within the slag. This condition could arise due to different processing conditions within the melt. This possibility, however, was taken into account and samples were taken from different parts of the melt such as from the top and bottom regions. An additional possibility is that the surrogates, which are not expected to volatilize, may have selectively partitioned into the refractory liner. Liners for the FY-94 work were an HP-CAST ZR-AL composed of $\mathrm{SiO}_{2}-27 \%, \mathrm{Al}_{2} \mathrm{O}_{3}-16 \%, \mathrm{ZrO}_{2}-54 \%$ and $\mathrm{CaO}-3 \%$. 


\section{CONCLUSIONS AND RECOMMENDATIONS}

The INEL small DC arc melter has proven to be a useful tool in supporting the efforts of several initiatives to remediate mixed low-level wastes at the INEL. These initiatives include the Buried Waste Integration Demonstration (BWID) Program, Private Sector Participation Initiative (PSPI) Program, and Integrated Waste Processing Facility (IWPF) Program. These programs took advantage of the capabilities of the INEL small arc melter to investigate the effects of various processing conditions in a DC arc melter on the properties of thermally treated mixed low-level waste.

\subsection{Arc Melter System and Operations}

An arc-melter facility having undergone a series of modifications has conducted volatilization and redox studies on simulated wastes containing toxic and high vapor pressure metals, as well as TRU surrogates. Operational observations reveal that there is more volatile and particulate emission from the melt chamber when the HVPMs and TRU are present in the simulated waste mix than when they are not. Obviously, the HVPMs contribute most to this increased particulate loading in the exhaust gases. Entrainment of particulate from the waste mix is increased when feeding material into a melt that has already been established. The small size of the pulverized feed particles contribute to this type of emission problem. This increase in particulate loading made it difficult for the operator to view the inside the melt chamber with the video monitor and adjust the position of the electrodes to account for the receding of the meltfeed interface and electrode loss.

Monitoring energy balance data (energy input vs. energy output as a function of time) revealed important insights into the ability of the arc melter to process material under various conditions. Crucible inserts provided better insulation from the water-cooled stainless steel crucible than coating the crucible with thin layers of mortar. This resulted in more heat being supplied to the simulated waste mixtures in a shorter time. For instance, in open melt conditions, six kilograms of material could be melted in 45 minutes using an insert vs. 1 hour otherwise. Establishment of a cold cap would prevent energy from being radiated away from the melt surface. This captured radiation energy would accelerate melting of the cold cap surface material and in some cases increase the overall temperature of the melt. The energy balance data revealed useful information about melting rates and material feeding rates in addition to maintenance problems.

Coatings on the carbon electrodes had a modest effect on increasing their lifetime and thereby increasing the time available for processing. Non-coated electrodes would erode along 
the entire length of the electrode showing progressively increased erosion closer to the tip. Coated electrodes eroded only at the tip, with the coatings protecting the upper portions from oxidation. Plasma-sprayed coatings of ceramic oxides, alumina, and zirconia were used in FY-93, and plasma-sprayed silicon and painted coatings of silicon carbide were used in FY-94.

Slag temperature measurements proved to be problematic. Type $C$ thermocouples encased in alumina sheaths lasted only minutes depending on the slag temperature. A water-cooled TC probe with an alumina sheath and a graphite extension tube coated with silicon carbide proved to be most effective for extended temperature measurements. The graphite extension tube must be long enough so as to not be affected by the water-cooled section of the probe.

Below are lessons learned in operating the present arc melter system:

1. For the initial heating period, two $80 \mathrm{~kW}$ power supplies set for $400 \mathrm{VOC}$ are required to provide stability to account for potentially large shifts in current and voltage. After operation has stabilized, one power supply may be turned off.

2. Operation at low temperatures $\left(<1400^{\circ} \mathrm{C}\right)$ and low power with the compositions studied is not conducive to stable operation and should be avoided.

3. Temperatures in excess of $2000^{\circ} \mathrm{C}$ can be easily obtained. The melt temperature may require monitoring with feedback control to maintain the desired set point.

4. When adding feed at low power and with manual control, it may be necessary to increase the power so that the cold, nonconducting feed.does not significantly alter the operating conditions and cause the arc to extinguish. For this system, $100 \mathrm{~A}$ or more is recommended.

5. Solidified slag from previous experiments melts more easily and can be operated at higher currents than the initial simulated-waste/soil mixture.

6. Exhaust lines must be cleaned out after each test to ensure that plugging will not occur.

7. The cold trap must be kept at the appropriate temperature range so that ice will not form but at the same time, it must sufficiently cool the exhaust gas. Water and ice, rather than liquid nitrogen, provided an adequate amount of cooling. 


\subsection{Effects of Redox Conditions}

The redox experiments conducted in FY-94 tested the extremes in reducing or oxidizing conditions and their effect on melt chemistry and crystallization. Reducing conditions for two melts were achieved by using different levels of carbon blended into the melt mix. In the case of these two melts, that was one-half of the stoichiometric amount of carbon needed to reduce iron oxides to metals and twice the stoichiometric amount. Two levels of oxidation were maintained by introducing air under the surface of the melt with a water-cooled air lance.

An overall generalization of the difference between slag material processed under reducing and oxidizing conditions is that the reduced melts produced mostly glassy slag while the oxidized melts developed substantially more crystalline structure even though the cooling rates were very similar. The highly oxidizing condition resulted in the highest volume fraction of crystalline phases. This may be an important factor to consider in the formulation of a final waste form. Some Cs appears to be interstitially bound to a chromite phase. No zirconolite was observed in any of these experiments. In part this may be due to unfavorable chemistry conditions and to rapid slag cooling that did not allow enough time for nucleation and growth to occur.

Redox conditions had little influence on the disposition of the HVPMs. With the exception of chromium, the HVPMs evaporated from the melt in both reducing and oxidizing environments. Chromium showed a strong tendency to form crystals in conjunction with iron, although the crystalline structures formed in reducing conditions tended to be much smaller and finer. The surrogates did not tend to collect preferentially in the crystalline phases as was hoped. This may be due primarily to relatively fast slag cooling rates once the melter is turned off.

Of the surrogates, only cerium demonstrated an ability to remain in the slag in significant amounts, retaining about half of the original amount in the simulated waste mix. The cerium was. found in the glassy phases of the slag. In general, the rest of the surrogates tended to be volatilized although there were exceptions. For instance, cesium showed modest retention under oxidizing conditions but was completely volatilized in the reducing environment. 


\subsection{Volatilization in a DC Arc Melter}

There were two experimental campaigns conducted during FY-93 and FY-94 to specifically try and quantify the volatilization of HVPMs and radionuclide surrogates under open melt and cold cap conditions. The first test series in FY-93 collected exhaust gases while feed material containing the HVPMs and surrogates was introduced into the melt with the auger feeder. The exhaust gas particulates were collected by an exhaust gas analyzer. After analysis by an independent laboratory, volatilization rates in units of milligrams per hour were calculated for the elements of interest.

Examination of the data showed only the slightest correlation for reduction in volatilization in the cold cap melts vs. the open melts. This conclusion, however, may only point to the need for a thicker cold cap layer. Only in the case chromium of was there a clear indication of reduced volatilization in the cold cap experiments. Results for the other elements show only a slight reduction in volatilization in most cases during cold cap conditions, but there are many instances in which the opposite is true.

Measured volatilization rates can be expected to be system dependent since the geometry, temperature profiles, exhaust gas flow rates, etc., which will affect volatilization will be unique for each melter system. Primary factors affecting volatilization are the amount and surface area of the slag, concentration of the volatile material in the slag, and slag temperature. In general, volatilization rates for the INEL small arc melter show the expected correlation between temperature and volatilization, i.e. higher rates for higher slag temperatures, although there are some exceptions. Lack of a strict correlation can likely be attributed to uncertainties in slag temperature and unknown HVPM and surrogate concentrations during exhaust sampling. In order to obtain reliable volatilization rate data for any processing system, detailed slag temperature must be taken along with slag samples to determine volatile element concentrations.

Volatilization testing was continued in FY-94, again under open melt and cold cap conditions. In these experiments, the arc melter exhaust system was modified to streamline the task of obtaining a global mass balance. Masses of the slag (including metal if any), particulates in the melter chamber, and particulate in the exhaust system were collected and measured. In order to do elemental masses balances, the slag and particulates were analyzed using energy dispersive $\mathrm{x}$-ray spectroscopy and $\mathrm{x}$-ray fluorescence spectroscopy. Additionally, the slag and particulates were analyzed using inductively coupled plasma-atomic emission absorption spectroscopy. All of these analytical methods produced similar results. 
A general mass balance comparing the amount of starting material with the amount of material after processing revealed an average mass loss of $10.7 \mathrm{wt} \%$. This is a typical amount expected to be lost from carbonated and hydrated compounds in the starting material which will be released as carbon dioxide and water vapor during processing. A more complete mass balance would include measurement of the exhaust gas flow rate and input air flow rate rather than assuming the deficit mass was part of the off-gas. While measurement and analysis of exhaust gas flows is necessary to obtain a complete mass balance, in practical terms, it is somewhat complex and expensive. Also, since conservation of total mass must hold, measurements of only solid masses may be considered adequate for the scope and requirements of this project.

The elemental mass balance for the HVPMs revealed that the majority of zinc, cadmium, and lead ended up in particulates in the melt chamber and exhaust system while chromium tended to remain in the slag. The elemental mass balances in general did not account for the metal amounts originally introduced, particularly for chromium having a mass balance closure of just $35 \%$. Mass balances for the other toxic metals on average were $80 \%$ for lead, $73 \%$ for zinc, and $67 \%$ for cadmium. Cesium tended to partition half into the slag and half into the off-gas particulates. The mass balance closure for cesium was just $60 \%$. Partitioning behavior of the surrogate elements, cerium and samarium, is uncertain due the very poor mass balance results ranging from $20-30 \%$. These elements are expected to remain in the slag, and indeed while the relative mass amounts found in the slag are much higher (about 10 times) than for the off-gas particulates, the poor mass balance closure leaves open the question about the ultimate fate of the surrogate elements.

A reason for the poor mass balances may be the result of two factors. First, the mass of the slag is substantially larger than that of the particulates. Therefore a small discrepancy in the measured concentrations of HVPMs and surrogates could cause large discrepancies in the overall mass balance for an element. Second, the widely varying mass closure results suggest the possibility of elemental partitioning to different parts of the slag. Although this possibility was taken into account by taking samples from the top and bottom parts of the melt, elements may have been concentrated in regions of the slag that were not sampled. Based on these possibilities, more samples need to be analyzed to determine average concentrations of an element in the slag.

An additional reason for the poor mass balance in the case of the surrogates may be the presence of the refractory liners. It is unknown whether the refractory liners could selectively react with components of the melt, particularly the surrogates, since this possibility was not investigated. Further work to explore this possibility should be funded, since, in an actual processing setting, selective migration of radionuclides would be entirely unwanted. 


\subsection{Conclusions}

The volatilization experiments conducted in FY-93 and FY-94 provided valuable information on partitioning of toxic heavy metals and radionuclides via surrogate elements in a high temperature arc melter processing system. During the course of the experiments many improvements to the data gathering and analysis procedures were made and areas where further improvements could be made were identified. As a minimum, data collection must include measurement of solid mass amounts distributed during processing and elemental analysis of specific areas where solids have accumulated within the processing system. Exhaust gas mass amounts and elemental analysis can be done if budget constraints allow and if the scope of a project require. This may be dictated for preproduction systems where EPA and other environmental regulations will necessitate off-gas measurements to ensure compliance of that system and future production systems. Off-gas measurements will allow total mass balance measurements to made but are not necessary to determine solid mass partitioning within the melter and air pollution control systems.

It is suspected that the standardless EDXS analysis used for elemental analysis tends to slightly overestimate the amounts of titanium, iron and zirconium. This can be seen particularly in the FY-93 volatilization tests where titanium and zirconium were used to normalize calculated compositions for comparison to EDXs data. For this reason it is recommended that for future work the SEM/EDXS equipment be calibrated with a specimen of known concentrations of these elements.

Measurement of volatilization rates for any specific processing system require good temperature and volatile element concentration measurements of the slag. Although individual processing systems will affect volatilization due to geometry, surface area of the melt, energy input mechanism, etc., slag temperature and volatile element concentration are the primary factors affecting volatilization. Future testing must include radioactive bench scale testing where these considerations are taken into account. Also modelling of the partitioning mechanisms within specific processing systems may prove to be an important aspect in gaining knowledge for control of volatilization during radioactive waste processing. 
The overall results of these experiments show that provisions must be made for the air pollution control system of any high temperature radioactive processing system containing toxic metals to deal with them since the majority of these metals volatilized. Approximately half or more of any cadmium, zinc, lead and cesium will be volatilized or entrained and end up in the off-gas system. In addition some radionuclide elements (based on results from the surrogate elements) will also end up in the off-gas system. Particulates containing these elements must either be rerouted back to the melter or treated as a separate secondary waste stream. 


\section{REFERENCES}

1. J. L. Mayberry et al., Preliminary Systems Design Study Assessment Report, EGG-WTD-9594, EG\&G Idaho, Inc., June 1991.

2. F. Feizollahi and W. J. Quapp, Integrated Thermal Treatment System Study - Phase 2 Results, INEL-95/0129, Lockheed Idaho Technologies Company, February 1996.

3. F. Feizollahi et al., Preliminary Stored Waste Systems Design Study for Low-Level TRU Waste Treatment Assessment Report, EGG-WTD-10254, June 1992.

4. J. E. Flinn et. al., Annual Report on the TRU Waste Form Studies with Special Reference to Iron-Enriched Basalt: 1980, EGG-FM-5366, EG\&G, Idaho, Inc., June 1981.

5. J. M. Welch, C. W. Sill, and J. E. Flinn, Leach Tests of Simulated Low-Level Transuranic Waste Forms Containing Transuranic Elements, EGG-FM-6153, EG\&G Idaho, Inc., January 1983.

6. G. A. Reiman, J. D. Grandy, and T. L. Eddy, Survey of INEL Research on the IronEnriched Waste Form, EGG-WTD-10056, EG\&G Idaho, Inc., January 1992.

7. P. C. Kong and G. A. Reiman, Improving Iron-Enriched Basalt with Additions of $\mathrm{ZrO}_{2}$ and $\mathrm{TiO}_{2}$, EGG-MS-10642, EG\&G Idaho, Inc., June 1993.

8. G. A. Reimann and P. C. Kong, "Iron-Enriched Basalt Waste Form Improved with $\mathrm{TiO}_{2}$ and $\mathrm{ZrO}_{2}$ ", Actinide Processing, (Proc.), p. 275, B. Mishra and W. A. Averill (eds.), The Metallurgical Society, Warrendale, PA, March 1994.

9. J. M. Welch, R. L. Miller, and J. E. Flinn, Fuel and Core Storage and Disposal - Development: FY-82 Immobilization of Three-Mile Island Core Debris, EGG-FM6059, EG\&G Idaho, Inc., June 1983.

10. J. M. Welch, R. L. Miller, and J. E. Flinn, "Immobilization of Three-Mile Island Core Debris," 2nd Int. Symp. Ceramics in Nuclear Waste Management, Chicago, April 1983.

11. J. G. Conley, P. V. Kelsey, and D. V. Miley, "Investigation of the Properties of IronEnriched Basalt with $\mathrm{TiO}_{2}$ and $\mathrm{ZrO}_{2}$ Addition," American Ceramic Society 85th Annual Meeting, 1983. 
12. T. L. Eddy, P. C. Kong, B. D. Raivo, and G. L. Anderson, Thermal Processing System Concepts and Considerations for RWMC Buried Waste, EGG-WTD-10058, EG\&G Idaho, Inc., February 1992.

13. P. C. Kong, J. D. Grandy, A. D. Watkins, T. L. Eddy, and G. L. Anderson, BenchScale Arc Melter for R\&D in Thermal Treatment of Mixed Wastes, EGG-MS-10646, EG\&G Idaho, Inc., May 1993.

14. T. L. Eddy, et. al., Modified Bench-Scale Arc Melter for Waste Processing, EG\&G Idaho, Inc., EGG-MS-10941, March 1994.

15. D. R. Lide (ed.), CRC Handbook of Chemistry and Physics, 75th Edition, Section 4, CRC Press, Boca Raton, 1994. 
Appendix A

\section{LDRD FY-94 Annual Report}


LDRD FY-1994 ANNUAL REPORT Project Number: 8714

Project Title: Sensing Techniques for Thermal Treatment of Mixed Waste

Project Leader: N.M. Carlson

PHONE 6-6302

II. FY 1994 ACCOMPLISHMENTS: What did you accomplish and how does this compare with your project plan? How did you demonstrate the viability of the idea?

Electrical signals from the arc melter were monitored on three separate arc melter runs. During these runs a Hall effect probe was used to measure the $A C$ transient current in the electrodes at various times and under various conditions during each run. Because of safety considerations, the voltage across the electrodes was not monitored. One run included a start with a steel bar for which baseline current data was obtained.

The current signal correlated with the state of operation of the arc melter, to the extent that the state was known from visual observation or from parameter settings. Obvious qualitative differences were observed in the current signal among start up, steady-state operation, and transient events, such as arc extinction and starting or stopping feed into the melter. These qualitative differences could be used to determine the state of the melter in real time, thus providing a basis for automatic control. However, better, independent, correlated observations of the state of the melter are required to confirm the few correlations observed in the three runs. One easy way to . accomplish this would be to use the weld vision system to observe the interior of the reactor, as was proposed in the renewal of this LDRD.

Mounts for acoustic sensors were designed and constructed and the data acquisition system was modified to obtain acoustical data. Due to the limitation of only being able to monitor three arc melter runs, no acoustical data was acquired. 


\section{LABORATORY DIRECIED RESEARCH AND DEVELOPMIENT}

FY-1994 ANNUAL REPORT

Project Number: 8714

Project Title: Sensing Techniques for Thermal Treatment of Mixed Waste

Project Leader: N.M. Carlson

PHONE 6-6302

Date Initiated: April, 1994

Prior Year Costs: $\$ 0$

FY-1994 Costs: $\$ 12 \mathrm{~K}$ 
Appendix B

Melter Off Gas Sampling Proceedures

B-1 


\section{Melter Off Gas Sampling Procedure}

1) Level and zero the Method $5(M-5)$ box manometer.

2) Record local atmospheric parameters and sample identification information on the data sheet.

3) Place the crushed ice/water mixture in the sample train assembly box.

4) Perform the first pretest leak check

a. Fully open the $\mathrm{M}-5$ bypass valve and close the $\mathrm{M}-5$ coarse valve.

b. Start the pump and operate for a 15 minute warm-up time, prior to leak checking the sample train.

c. Connect the sample train assembly to the pump and place a stopper in the first impinger inlet (will be connected to the in the following step).

d. Open the M-5 coarse valve to mid-position.

e. Slowly close the bypass valve until a 15 in. Hg vacuum is obtained. To not reopen the bypass valve, since the impinger water may be drawn out.

f. Note the leak rate measured by the dry gas meter (DGM). Failure is defined as leakage above $0.02 \mathrm{cfm}$ or above $4 \%$ of the average sampling rate. If the leakage is excessive, check the tightness of the fittings along the sampling flowpath.

g. After a successful leak test, slowly break the vacuum upstream of the impinger assembly.

h. Return the M-5 bypass valve to the fully open position and the coarse valve to the fully cooled position.

i. Record the pretest leak rate on the data sheet.

5) Perform the second pretest leak check

a. Check/close the sampling valve.

b. Connect the sample train assembly to the melter through the swaglock fitting.

c. Repeat steps $d$ through $i$ in 3 ) above.

6) Record the initial DGM reading. 
7) When the melter is fully operational, observe the melter air inlet flowrate on the melter digital flow meter.

8) Collect a sample as follows

a. Open the $M-5$ bypass valve and the coarse valve.

b. Open the melter sampling valve, then close the melter baghouse valve. Caution: Some reverse flow, initiated by the baghouse vacuum, may occur. Watch the sampling rate, $\mathrm{dH}$ on the $\mathrm{M}-5$ manometer during this process.

c. Record the start time.

d. Slowly close the bypass valve until the desired manometer level differential is obtained, or until the inlet flow rate on the digital meter noted in step 6) is matched with the flowrate prior to sampling.

e. Adjust the M-5 bypass valve during sampling as necessary to maintain the desired flowrate.

f. Record complete sets of data at least once each 5 minutes during the sampling period.

g. Ensure the air temperature exiting the sample train assemble does not exceed $68 \mathrm{~F}$. Add ice to sample train assembly box as necessary to maintain exit air temperature.

h. To conclude the sampling, open the melter baghouse valve, the close the M-5 coarse valve.

i. Record the sampling stop time.

j. Close the melter sampling valve. Note: A slight vacuum will exist between the sample train assemble and the melter sampling valve.

k. Record the final set of data corresponding to the stop time.

9) Perform the post test leak check

a. Fully open the M-5 bypass valve and close the M-5 coarse valve.

b. Open the coarse valve to the mid-position.

c. Slowly close the bypass valve until a vacuum is reached that is greater than the maximum value obtained during the sample run.

d. Note the leak rate measured by the DGM. Failure criteria are the same as before. Excessive leakage requires either adjustment of flow volume data or voiding the run.

e. After a successful leak test, slowly break vacuum upstream of the sample train assembly.

f. Shut off the pump.

10) Disconnect the filter/impinger assembly and cap off the melter end of the assembly. Transfer the assembly to the designated area for sample recovery. 
Appendix C

Composition and Normalization Calculation Worksheets

C-1 


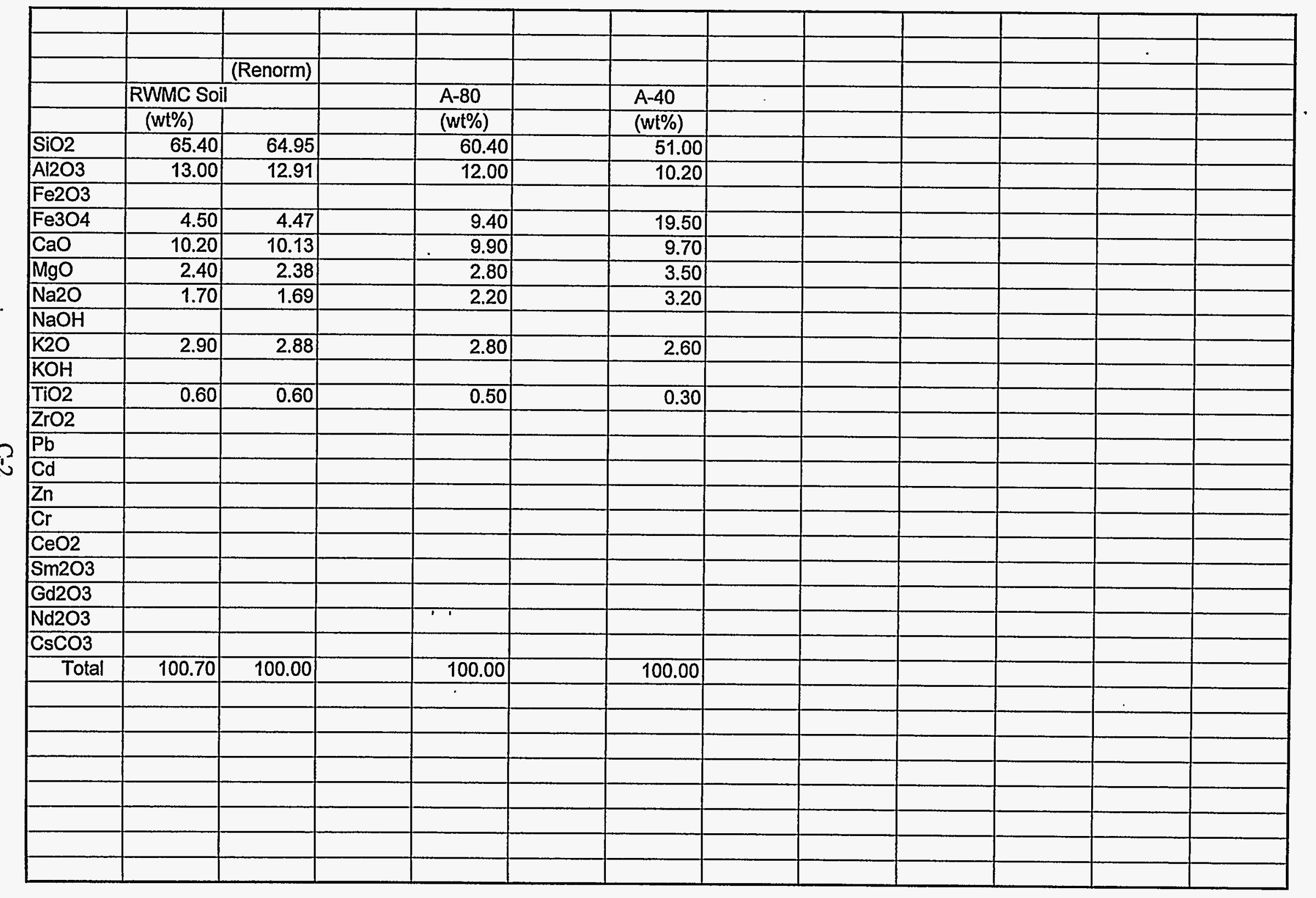




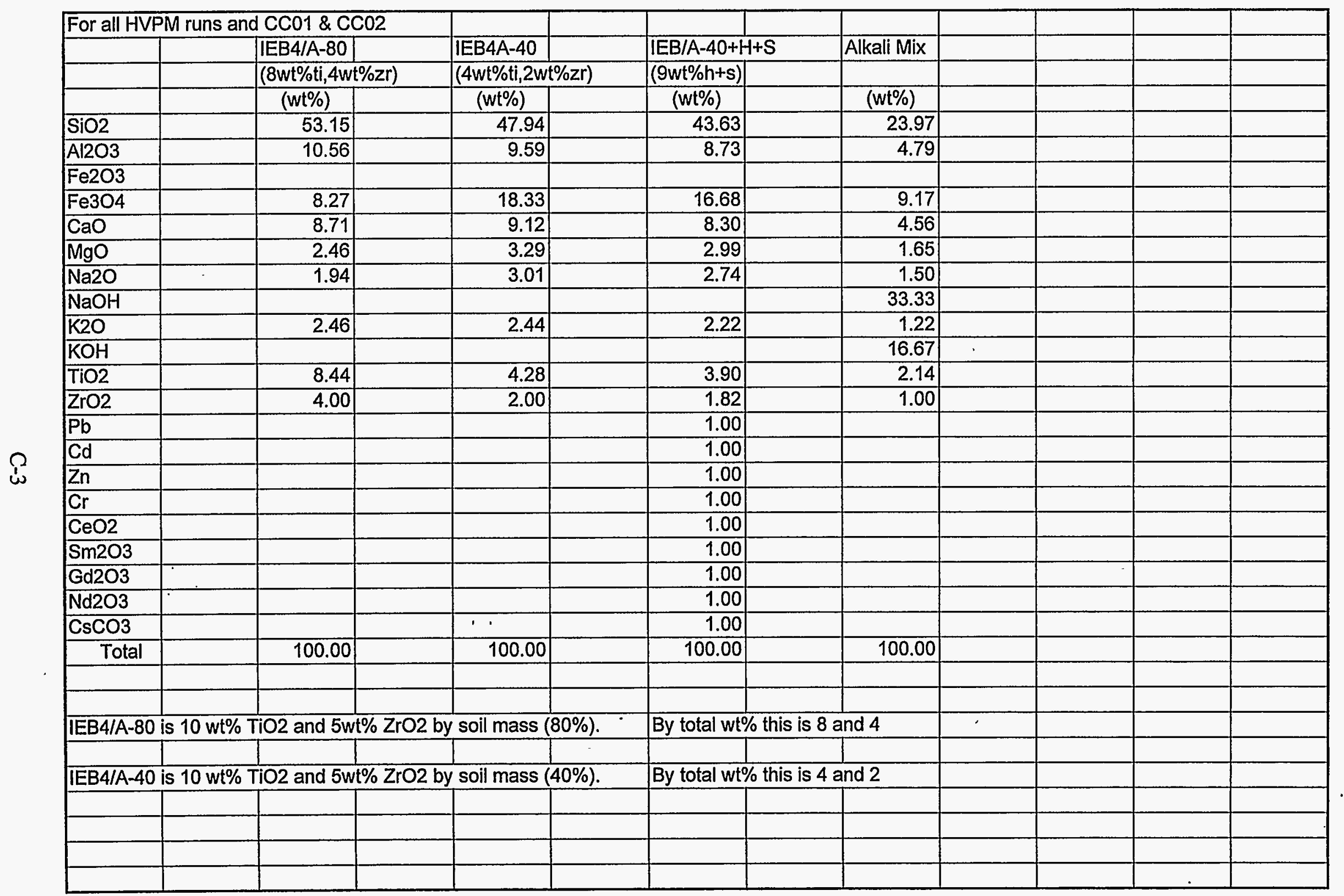




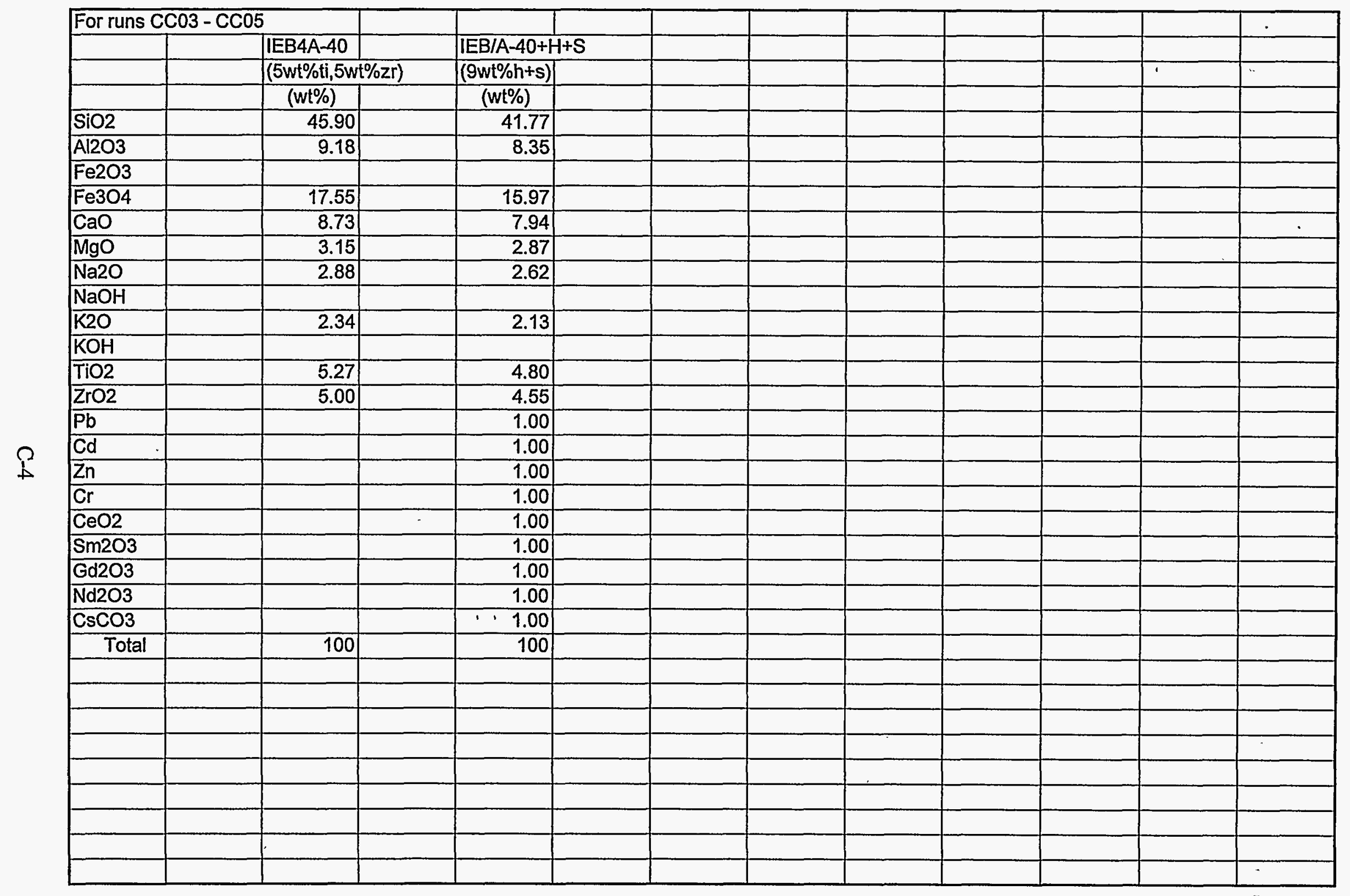




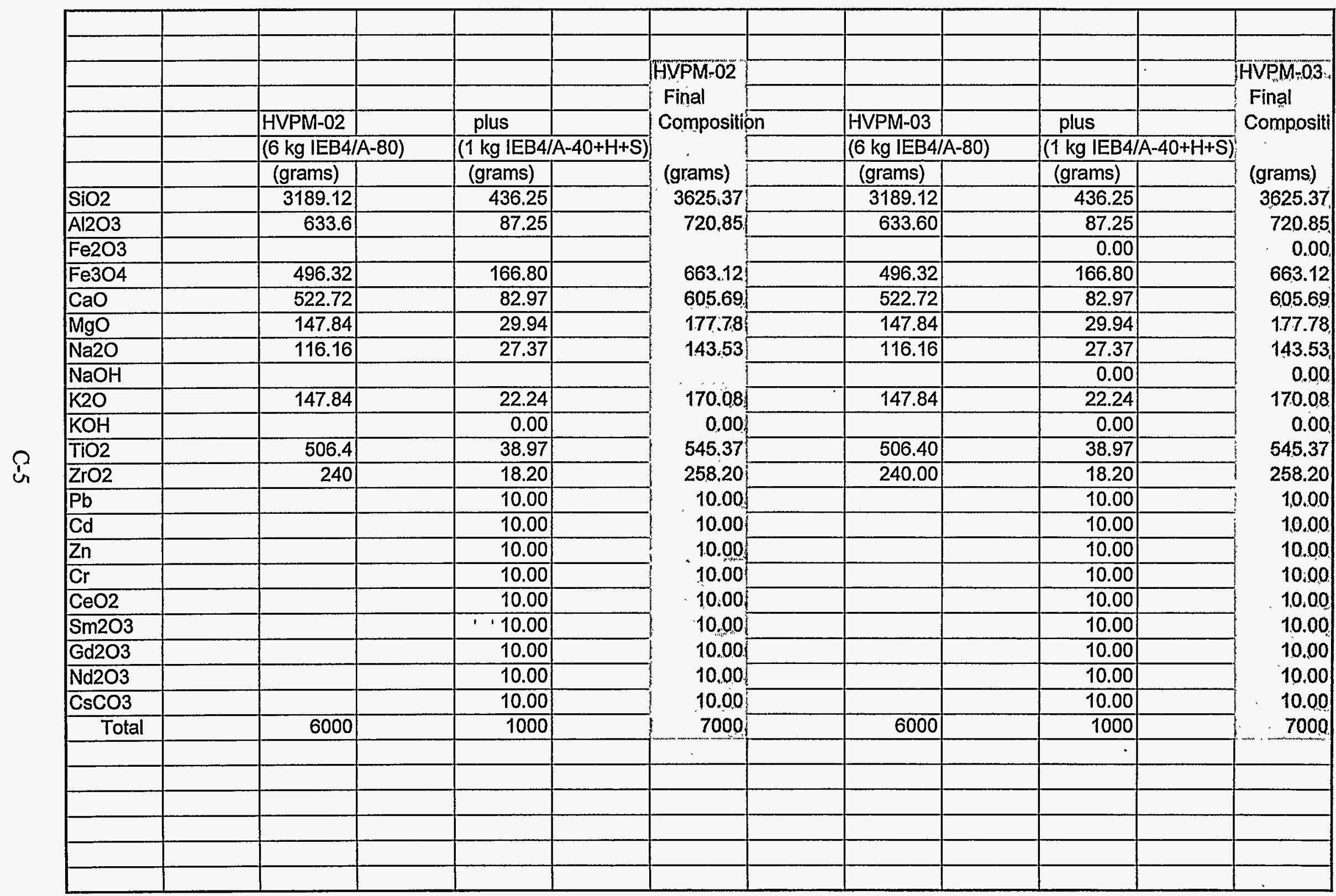




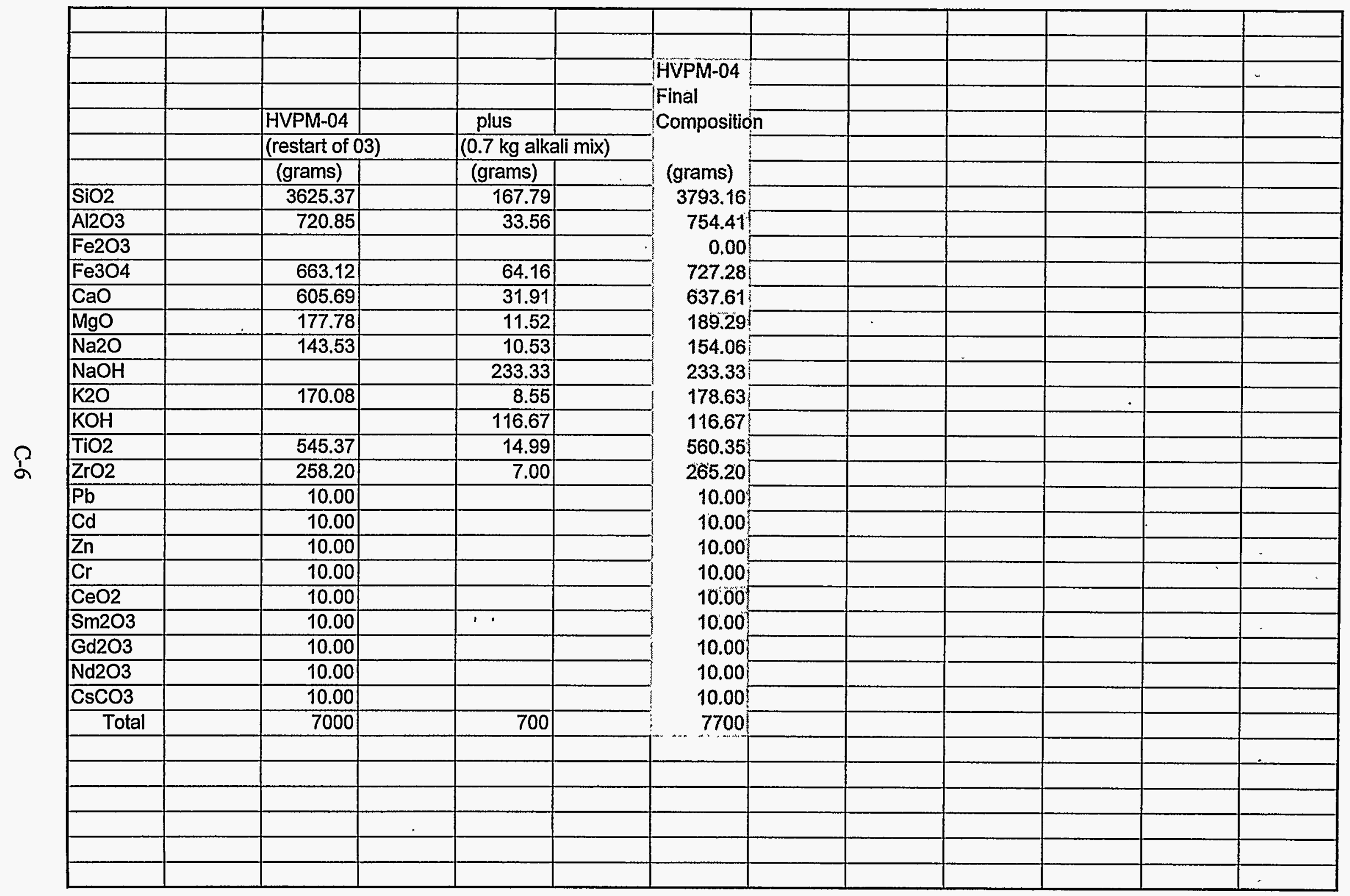




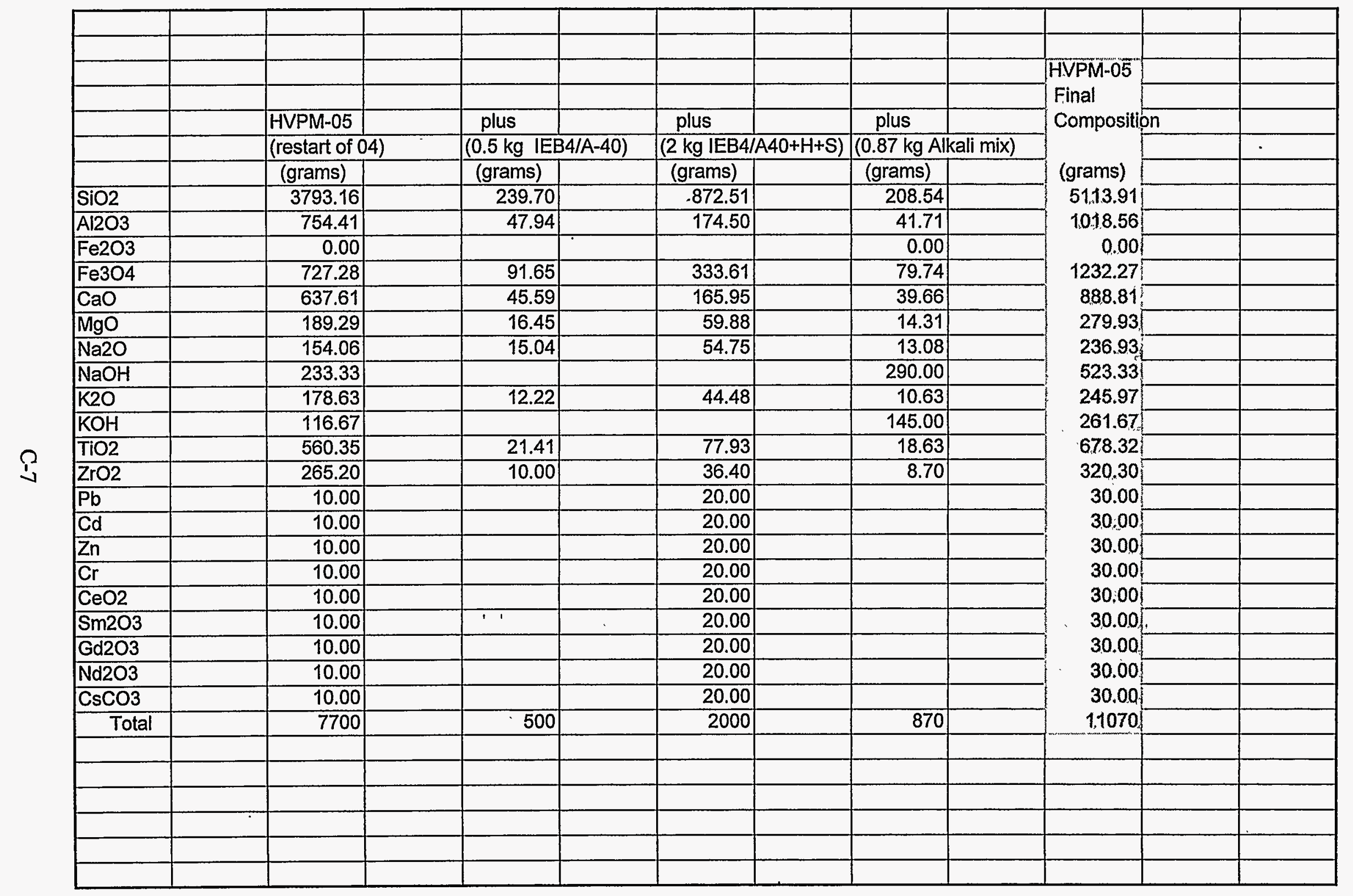




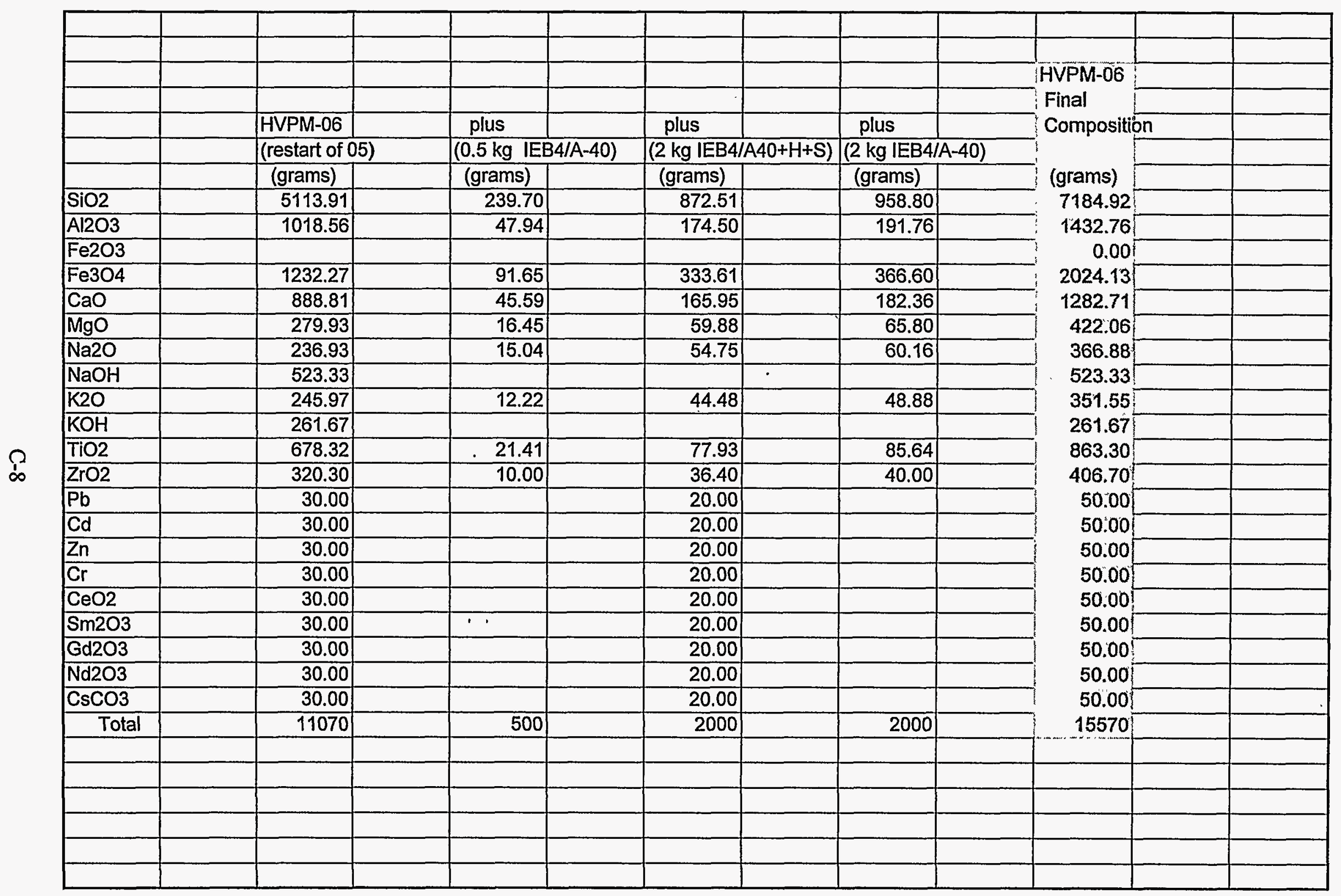




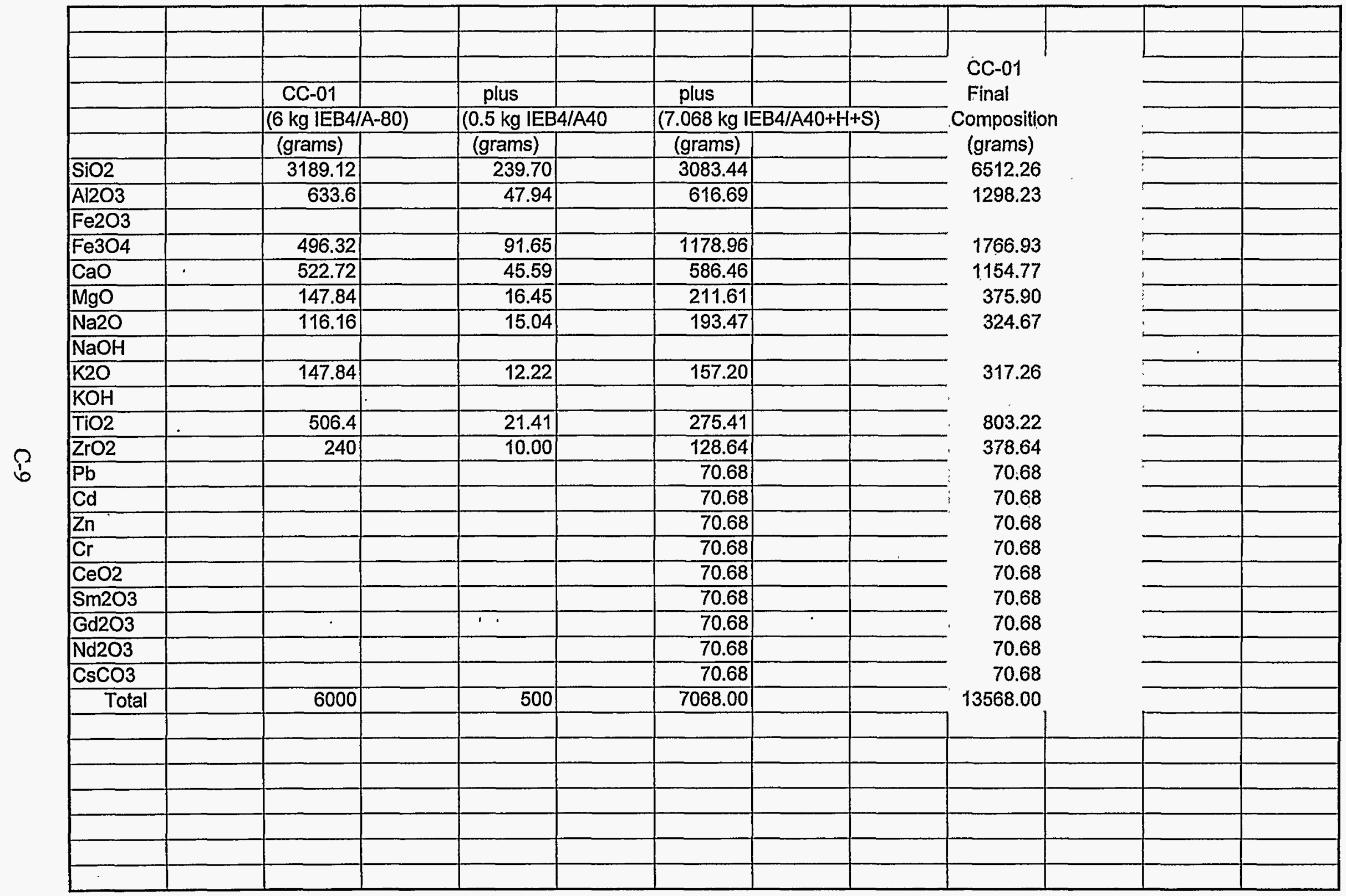




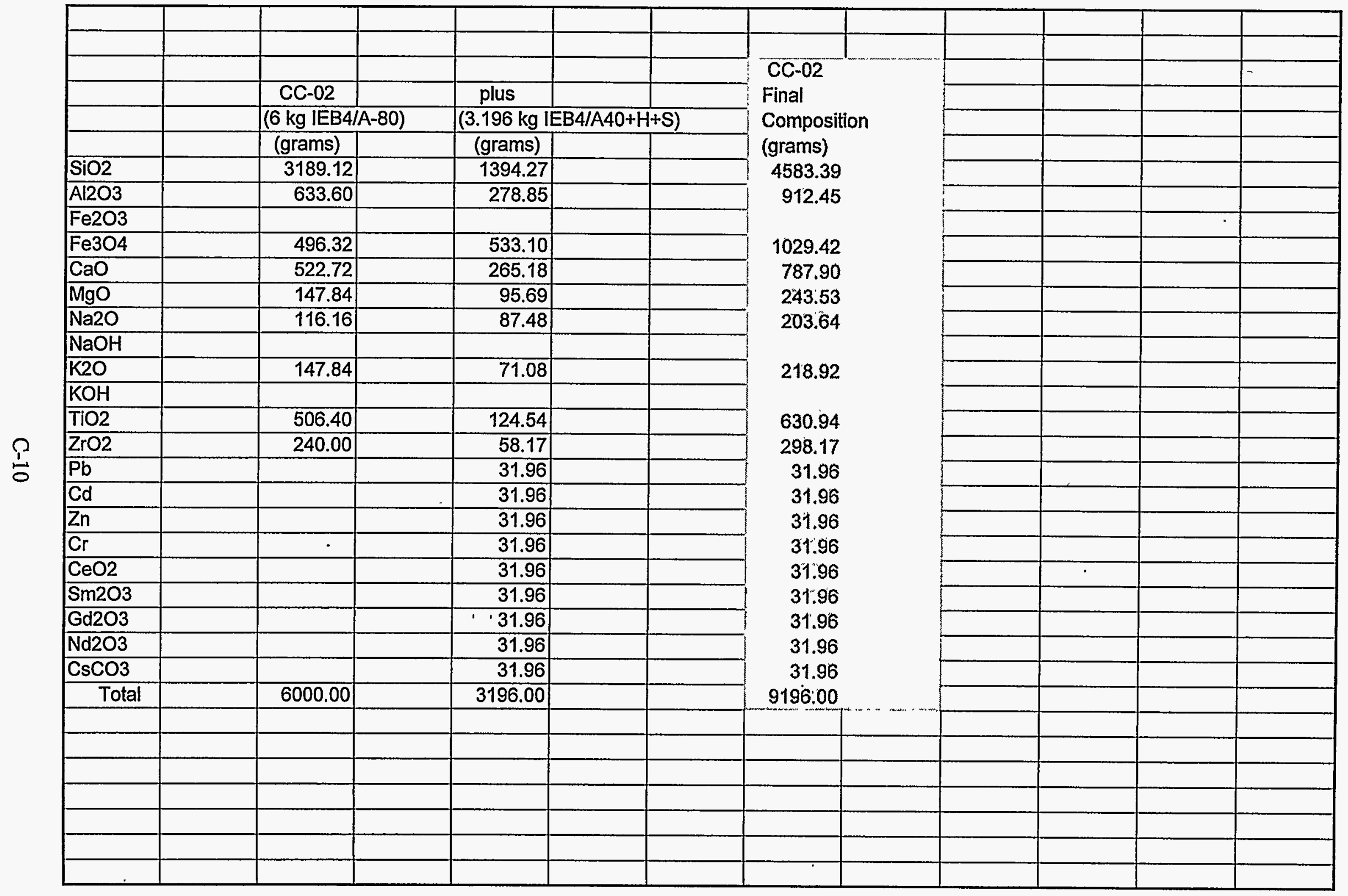




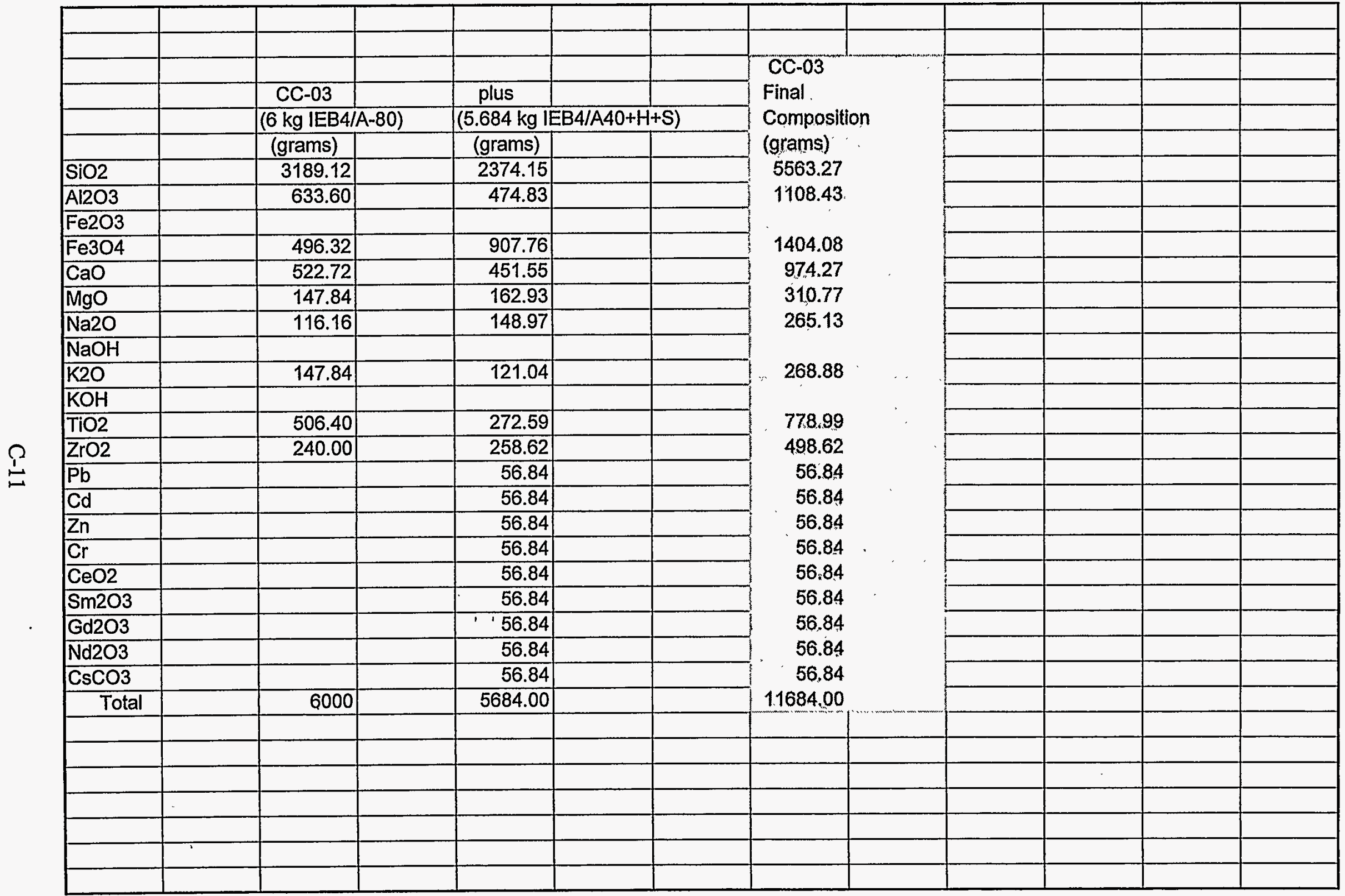




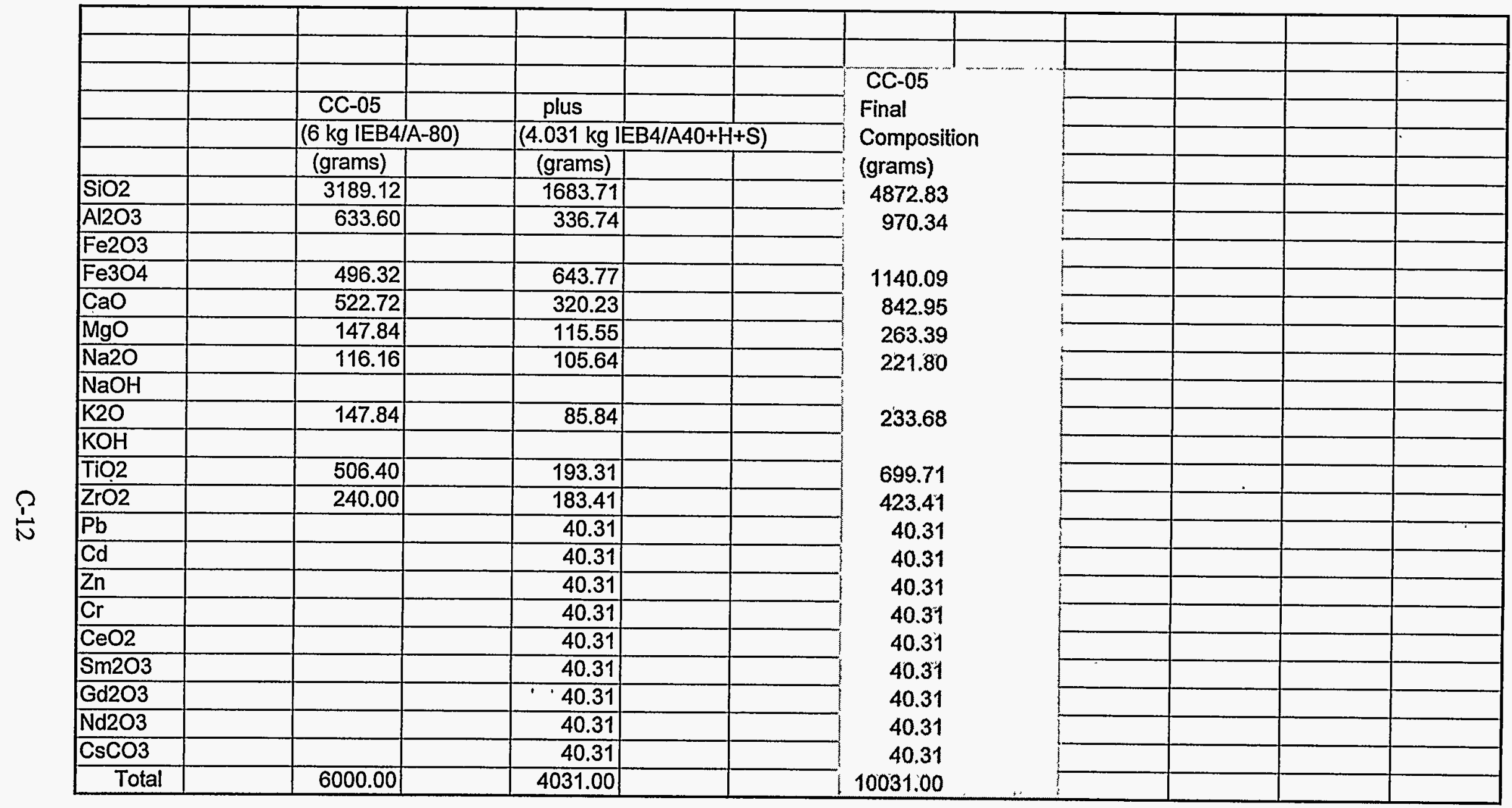




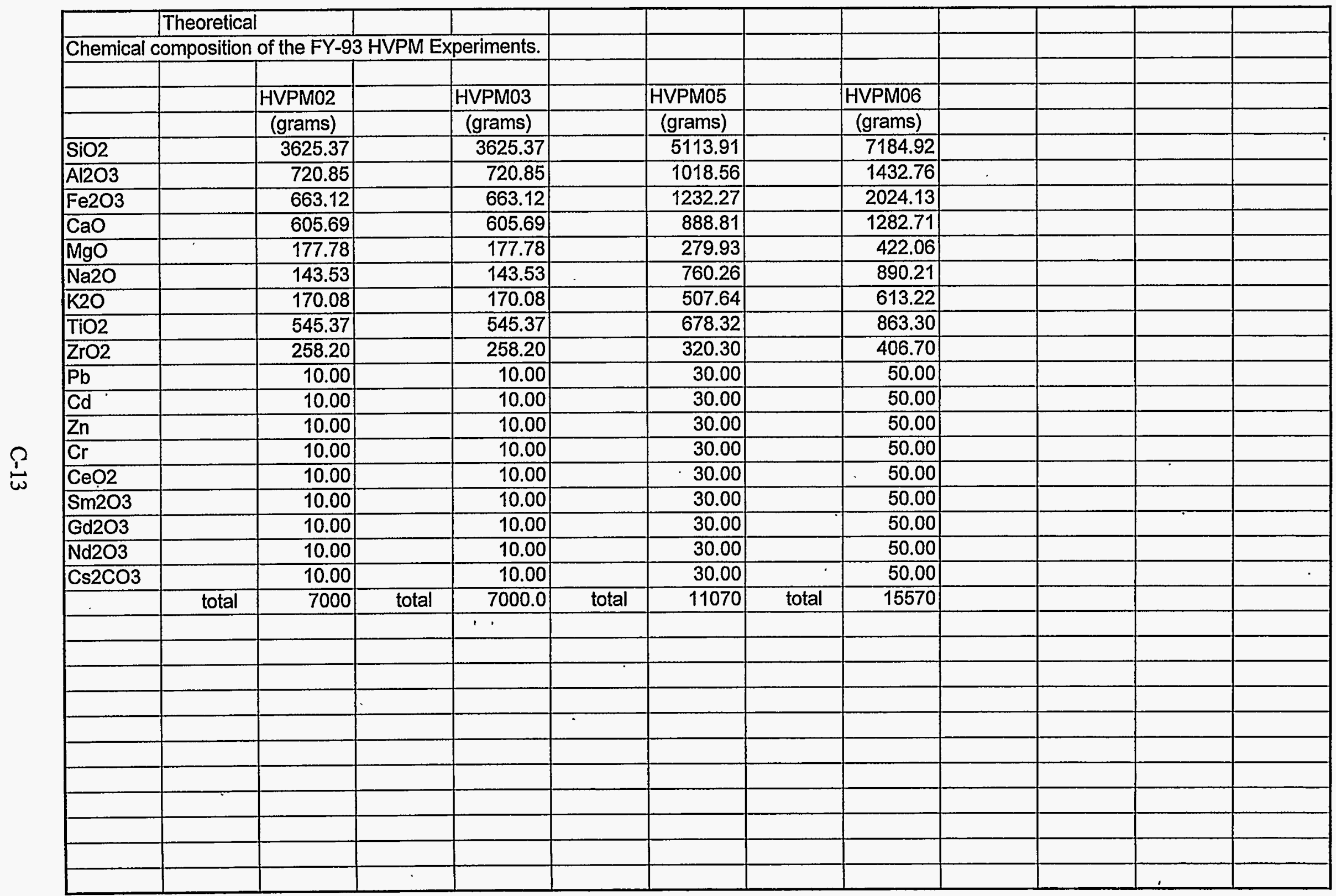




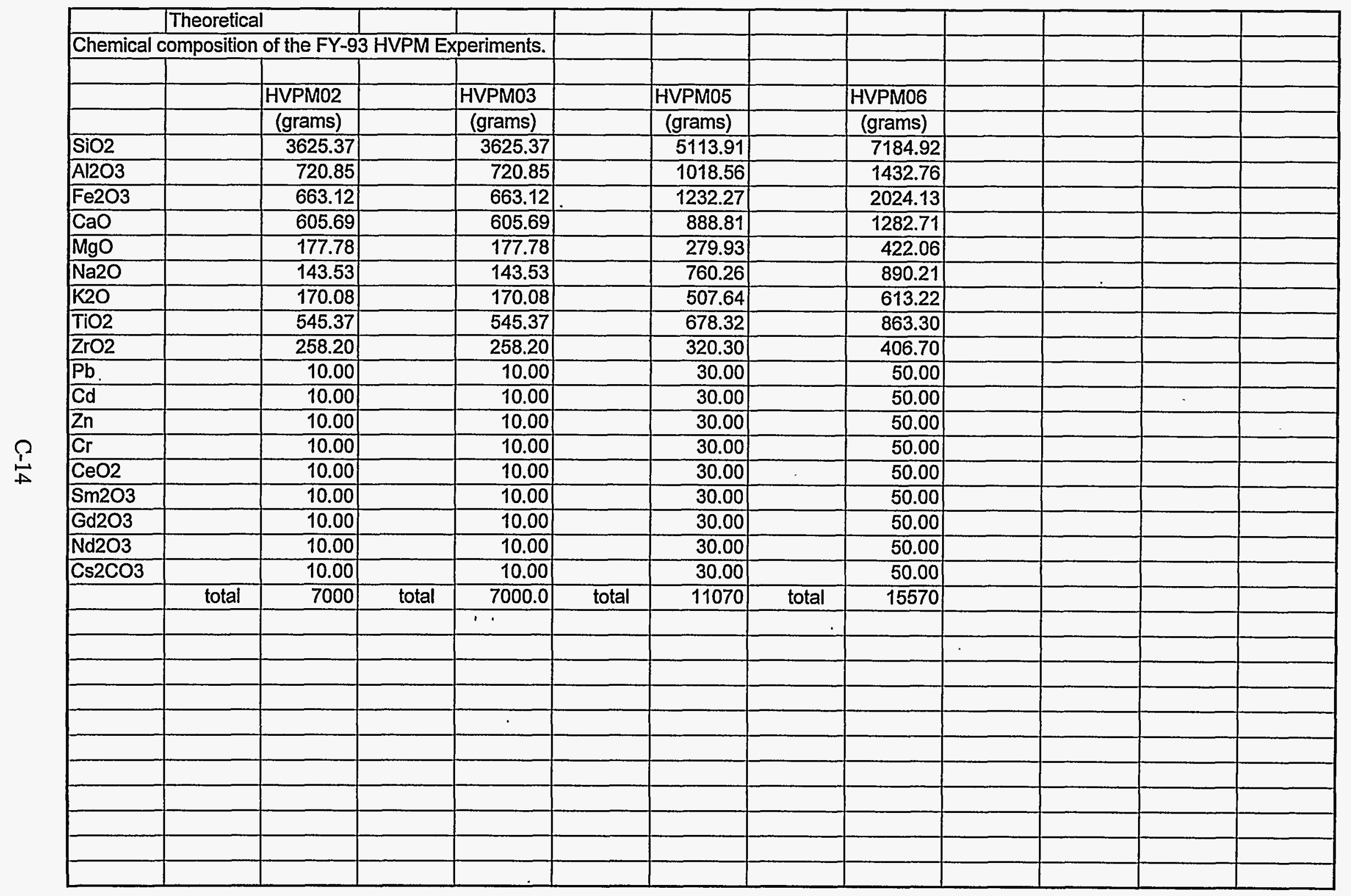




\begin{tabular}{|c|c|c|c|c|c|c|c|c|c|c|c|}
\hline & & & & & & & & & & & \\
\hline HVPM02 & & & & correct & correct & & slag & & (Ti basis) & (Zr basis) & \\
\hline & & metals & oxide & with & with & & chemical & & amount & amount & \\
\hline & & basis & basis & titanium & zirconium & . & analysis & & retained & retained & \\
\hline & $\mathrm{m} / \mathrm{o}$ ratio & (ppm) & (ppm) & (ppm) & (ppm) & & (ppm) & & $\%$ & $\%$ & \\
\hline SiO2 & 0.467 & 241864 & 276046 & 554544 & 477614 & & 276000 & & 50 & 58 & \\
\hline $\mathrm{Al} 2 \mathrm{O3}$ & 0.529 & 54476 & 48503 & 124901 & 107574 & & 54300 & & 43 & 50 & \\
\hline $\mathrm{Fe} 2 \mathrm{O} 3$ & 0.699 & 66217 & 28514 & 151823 & 130761 & & 161000 & & 106 & 123 & \\
\hline$\overline{\mathrm{CaO}}$ & 0.715 & 61867 & 24660 & 141848 & 122170 & & 96400 & & 68 & 79 & \\
\hline $\mathrm{MgO}$ & 0.603 & 15314 & 10083 & 35113 & 30242 & & 20100 & & 57 & 66 & \\
\hline $\mathrm{Na2O}$ & 0.742 & 15214 & 5290 & 34883 & 30044 & & 5150 & & 15 & 17 & \\
\hline $\mathrm{K} 2 \mathrm{O}$ & 0.830 & 20167 & 4131 & 46238 & 39824 & & 24900 & & 54 & 63 & \\
\hline TiO2 & 0.599 & 46668 & 31242 & 107000 & 92157 & & 107000 & & 100 & 116 & \\
\hline $\mathrm{ZrO} 2$ & 0.740 & 27295 & 9590 & 62583 & 53901 & & 53900 & & 86 & 100 & \\
\hline $\mathrm{Pb}$ & 1.000 & 1429 & 0 & 3275 & 2821 & & 262 & & 8 & 9 & \\
\hline $\mathrm{Cd}$ & 1.000 & 1429 & 0 & 3275 & 2821 & & 463 & & 14 & 16 & \\
\hline $\mathrm{Zn}$ & 1.000 & 1429 & 0 & 3275 & 2821 & & 1320 & & 40 & 47 & \\
\hline$\overline{\mathrm{Cr}}$ & 1.000 & 1429 & 0 & 3275 & 2821 & & 1550 & & 47 & 55 & \\
\hline $\mathrm{CeO} 2$ & 0.814 & 1163 & 266 & 2666 & 2296 & & 1220 & & 46 & 53 & \\
\hline $\mathrm{Sm} 2 \mathrm{O3}$ & 0.862 & 1231 & 197 & 2823 & 2432 & & 1210 & & 43 & 50 & \\
\hline $\mathrm{Gd} 2 \mathrm{O} 3$ & 0.868 & 1240 & 189 & 2843 & 2449 & & 1190 & & 42 & 49 & \\
\hline Nd2O3 & 0.857 & 1224 & 204 & 2807 & 2418 & & 1250 & & 45 & 52 & \\
\hline $\mathrm{Cs} 2 \mathrm{CO} 3$ & 0.816 & 1166 & 263 & 2673 & 2302 & & 1210 & & 45 & 53 & \\
\hline & & 560822 & 439178 & 1285847 & 1107466 & Total & 808425 & & & & \\
\hline & & & & & & & & & & & \\
\hline & & Total (ppm) & 1000000 & & & & & & & & \\
\hline & & & & & & & & & & & \\
\hline & & & & & & & & & & & \\
\hline & & & & & & & & & & & \\
\hline & & & & & & & & & & & \\
\hline & & & & & & & & & & & \\
\hline & & & & & & & & & & & \\
\hline & & & & & & & & & & & \\
\hline
\end{tabular}




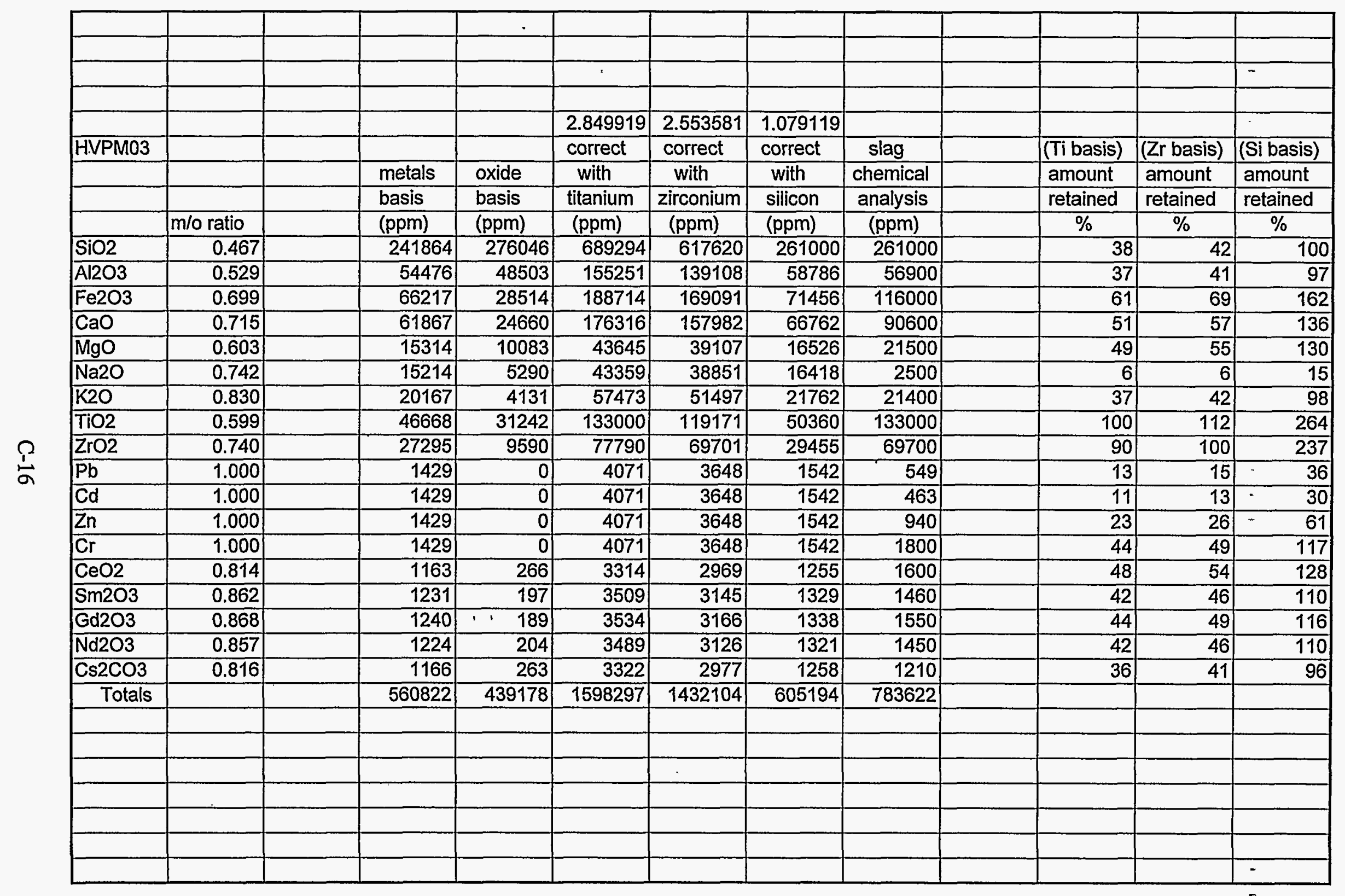




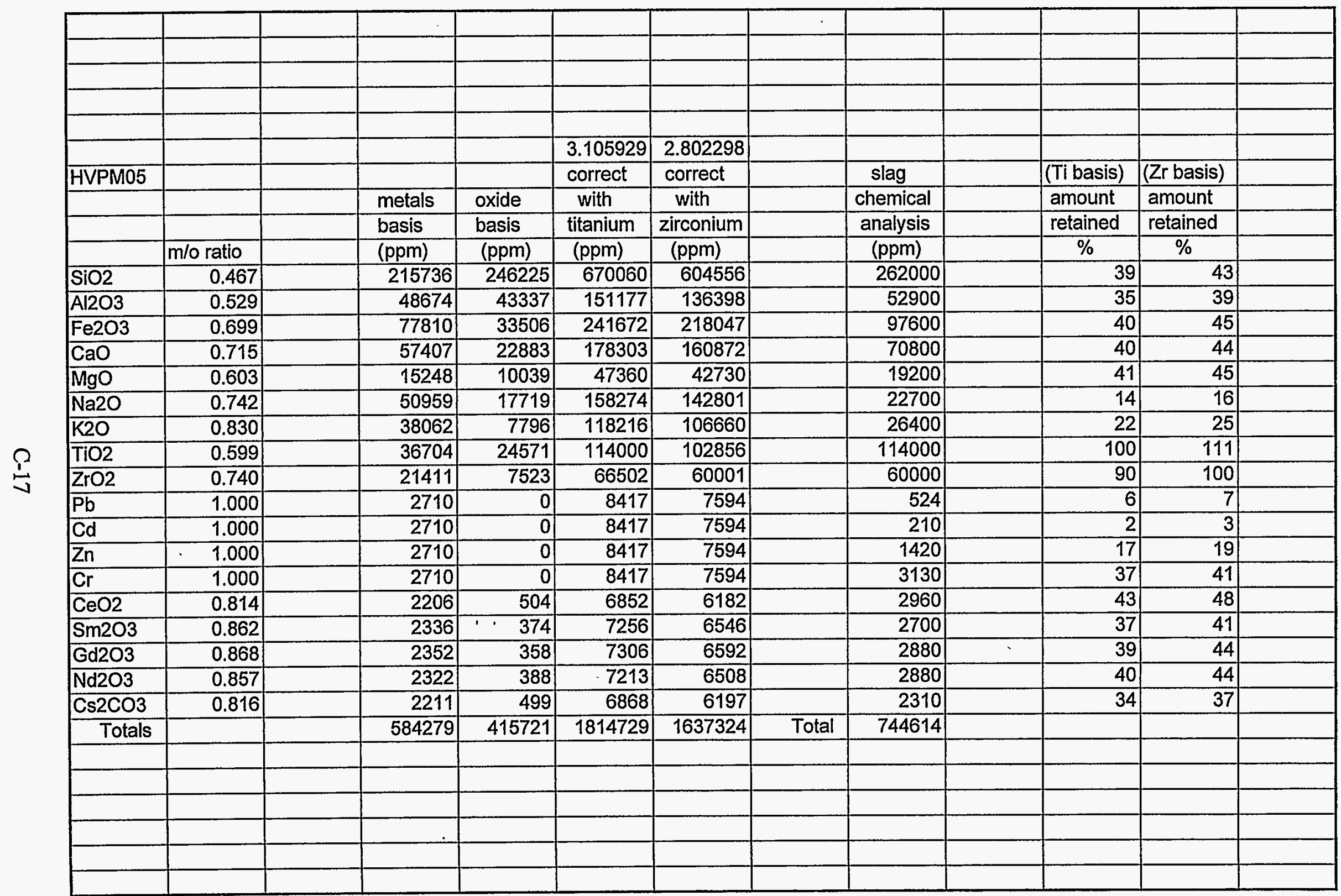




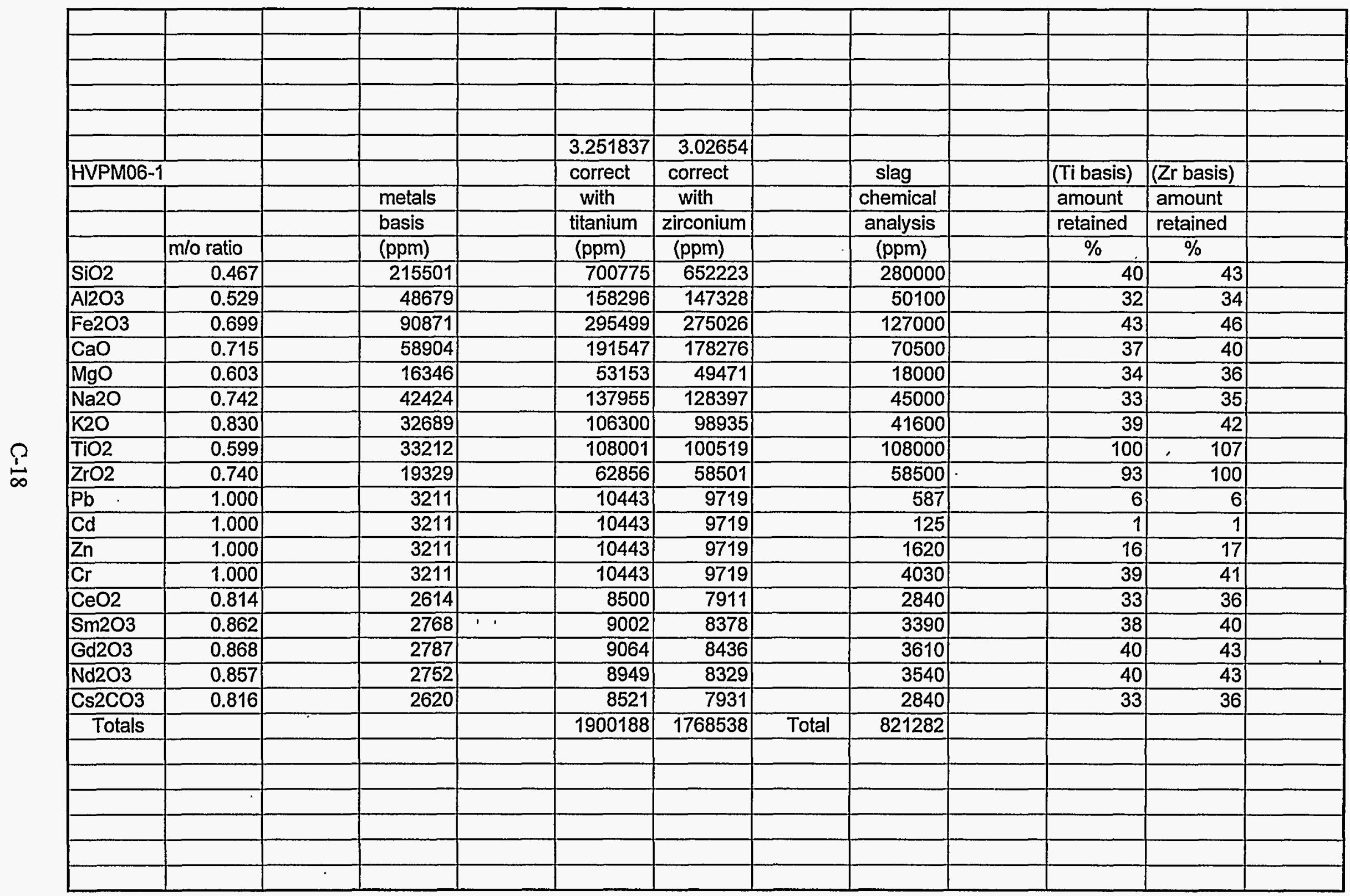




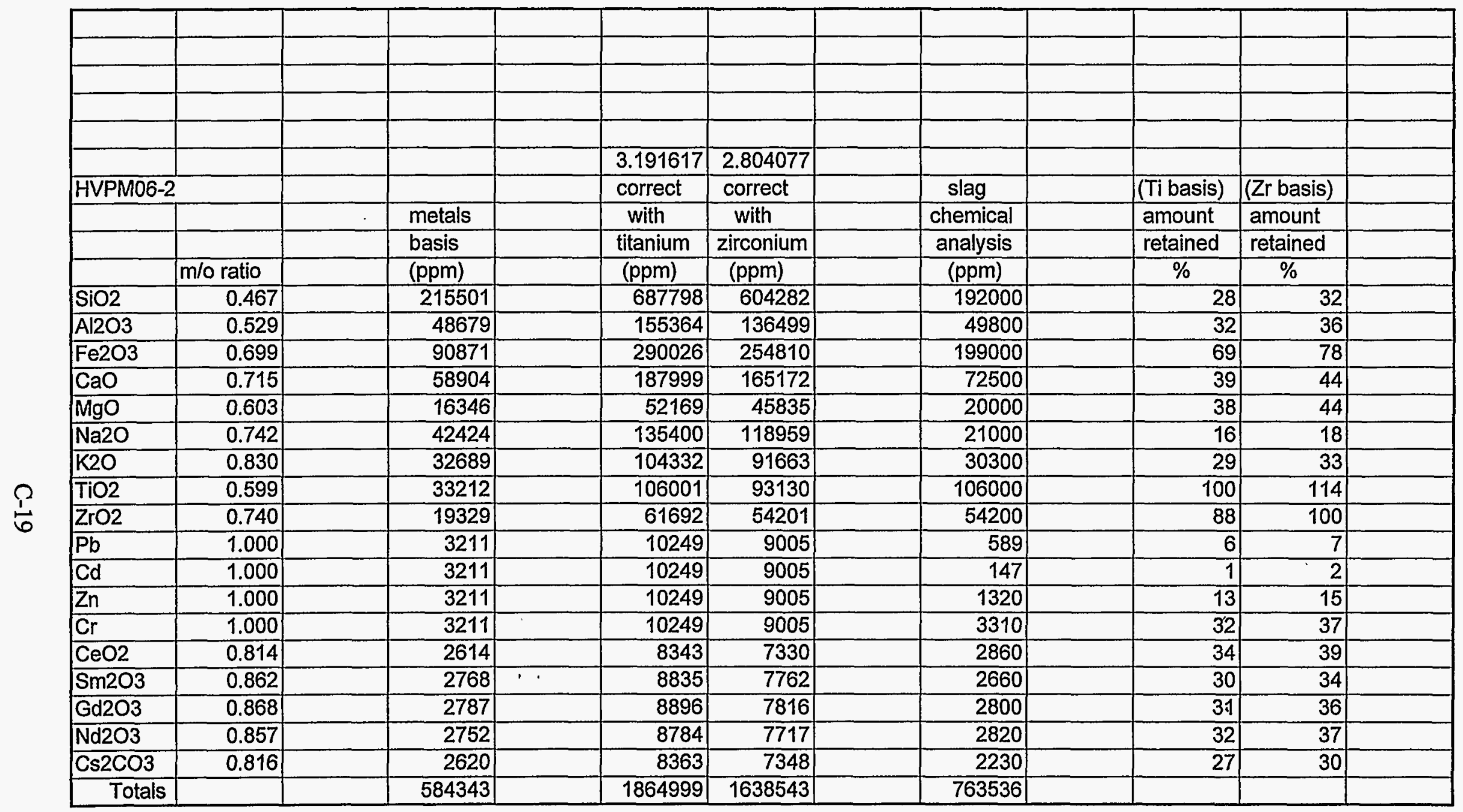




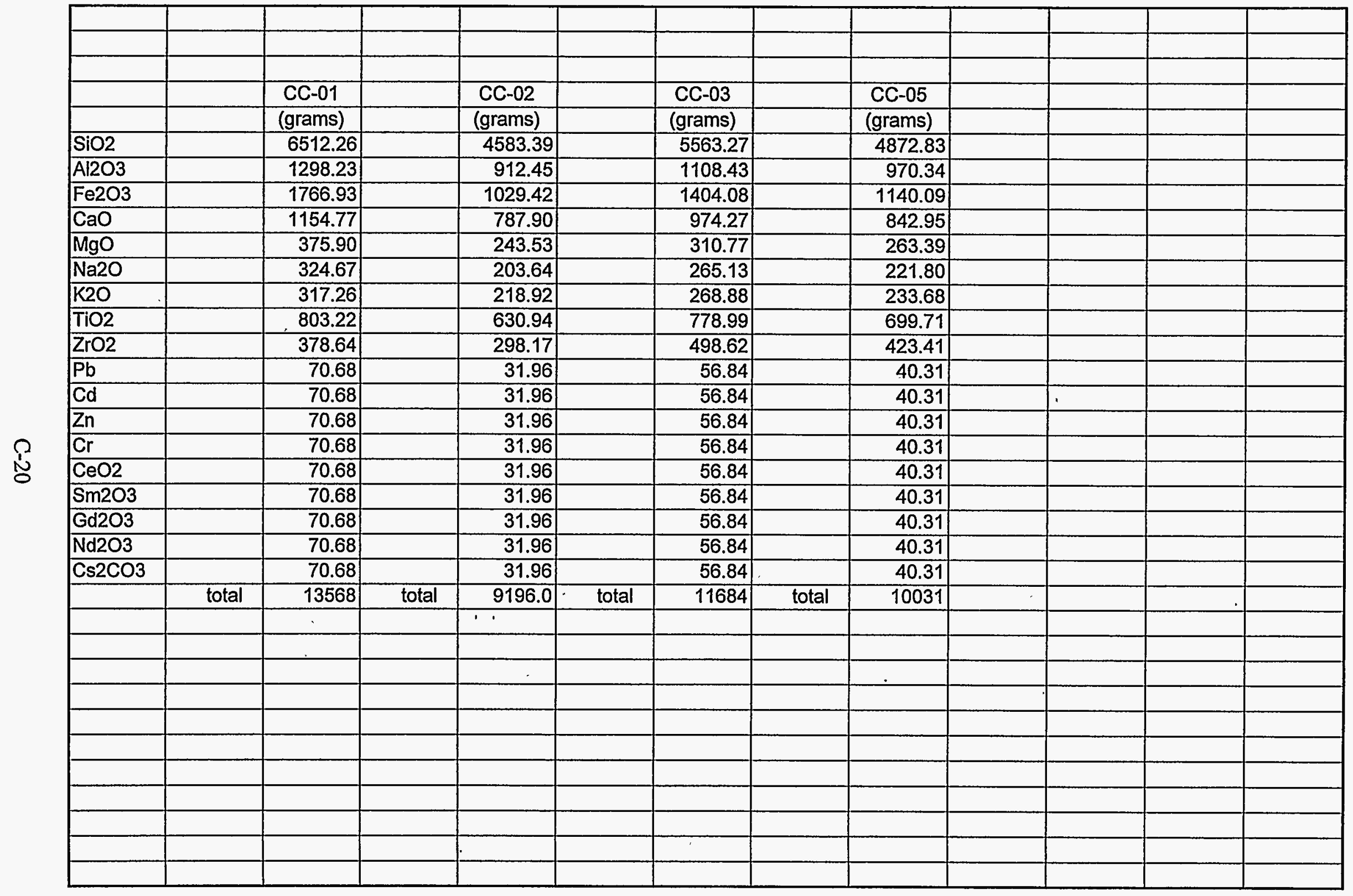




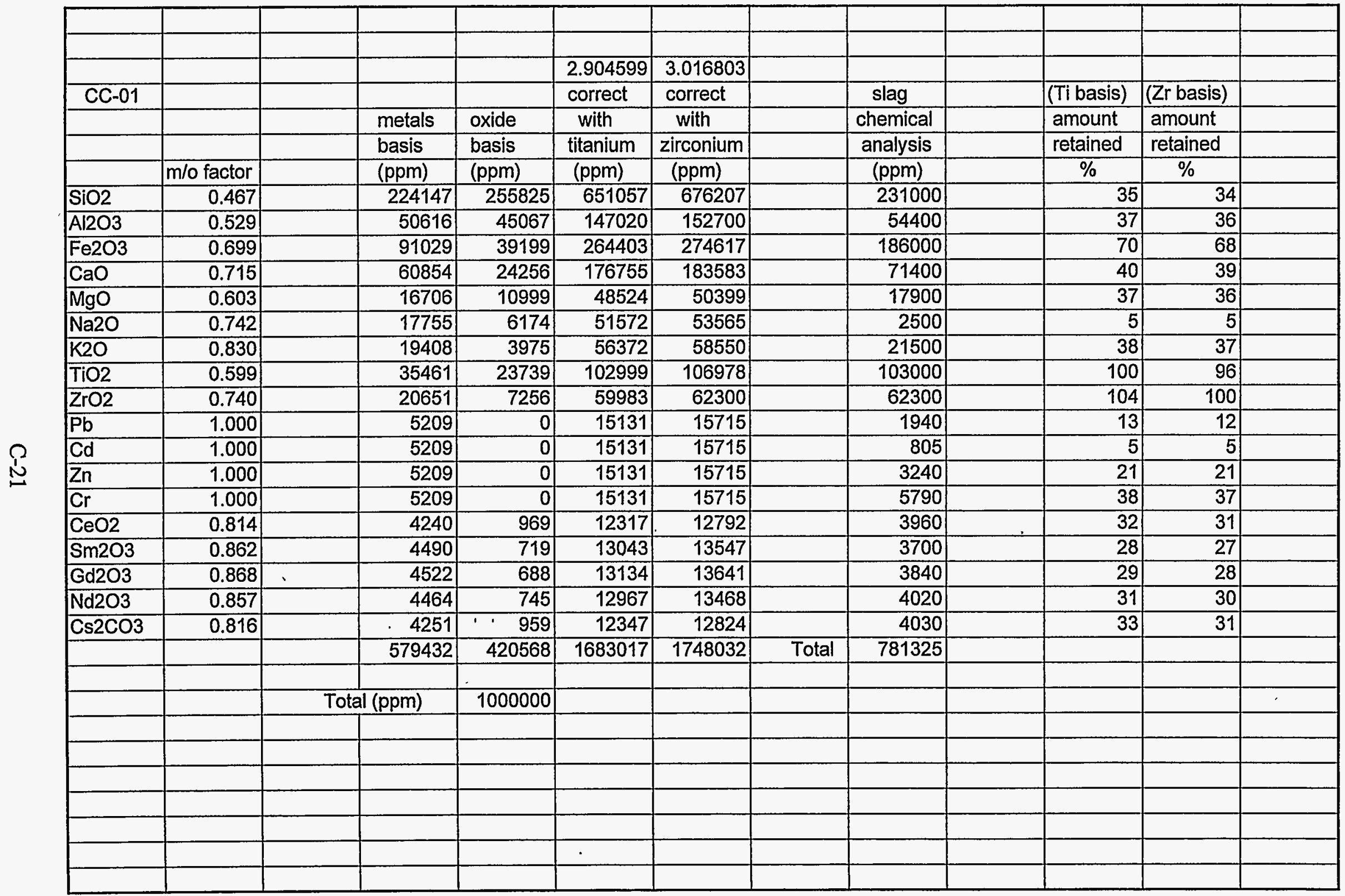




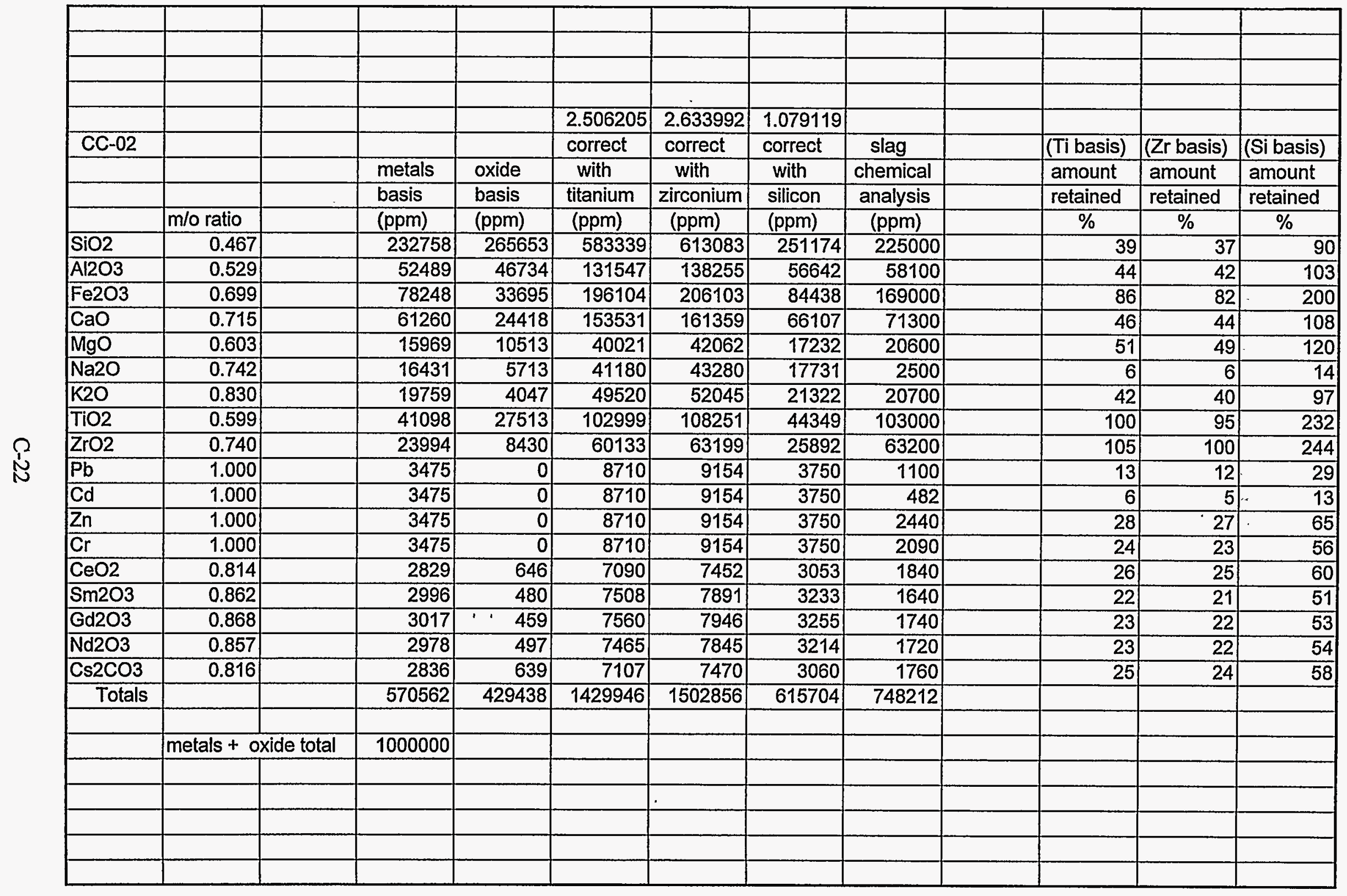




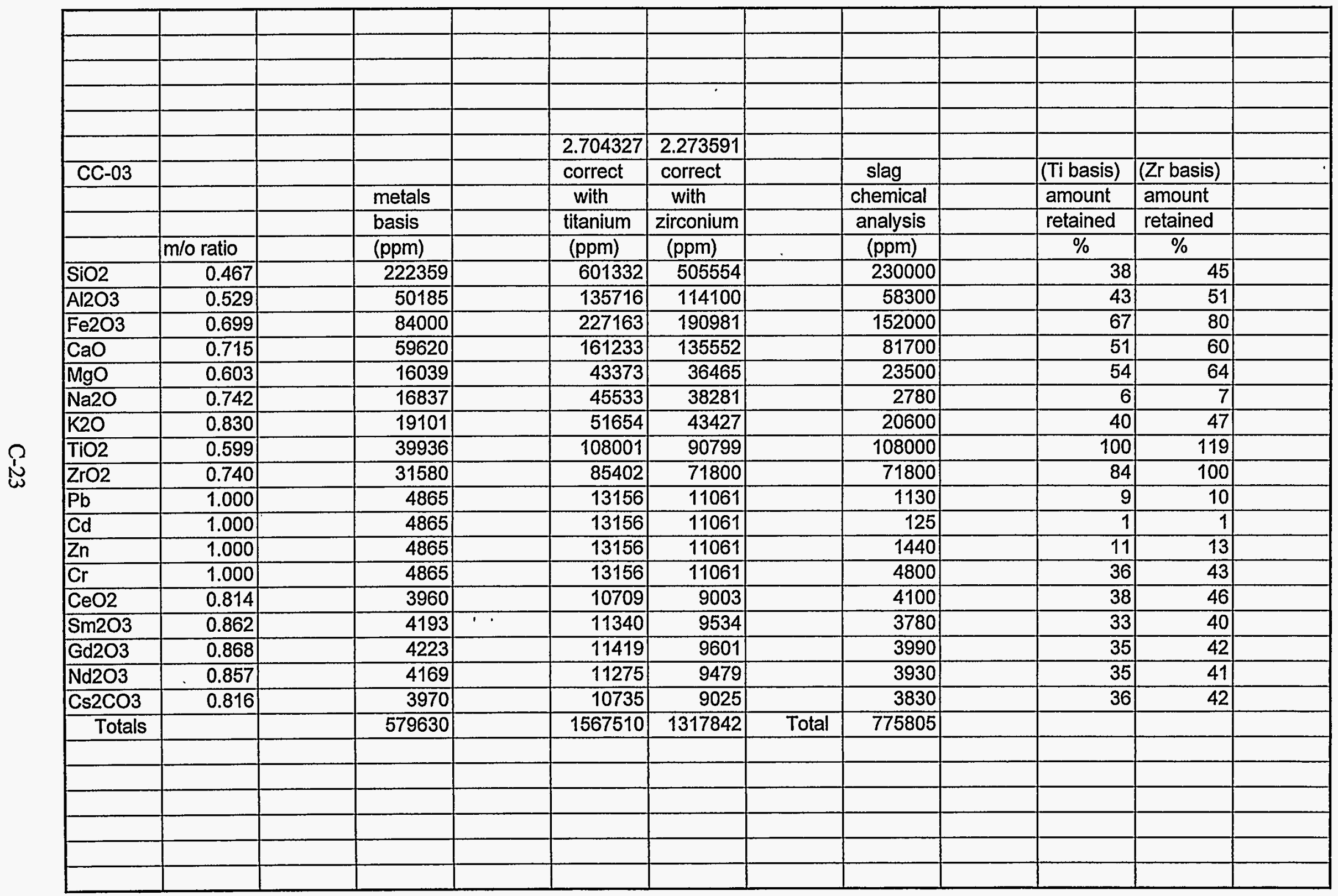




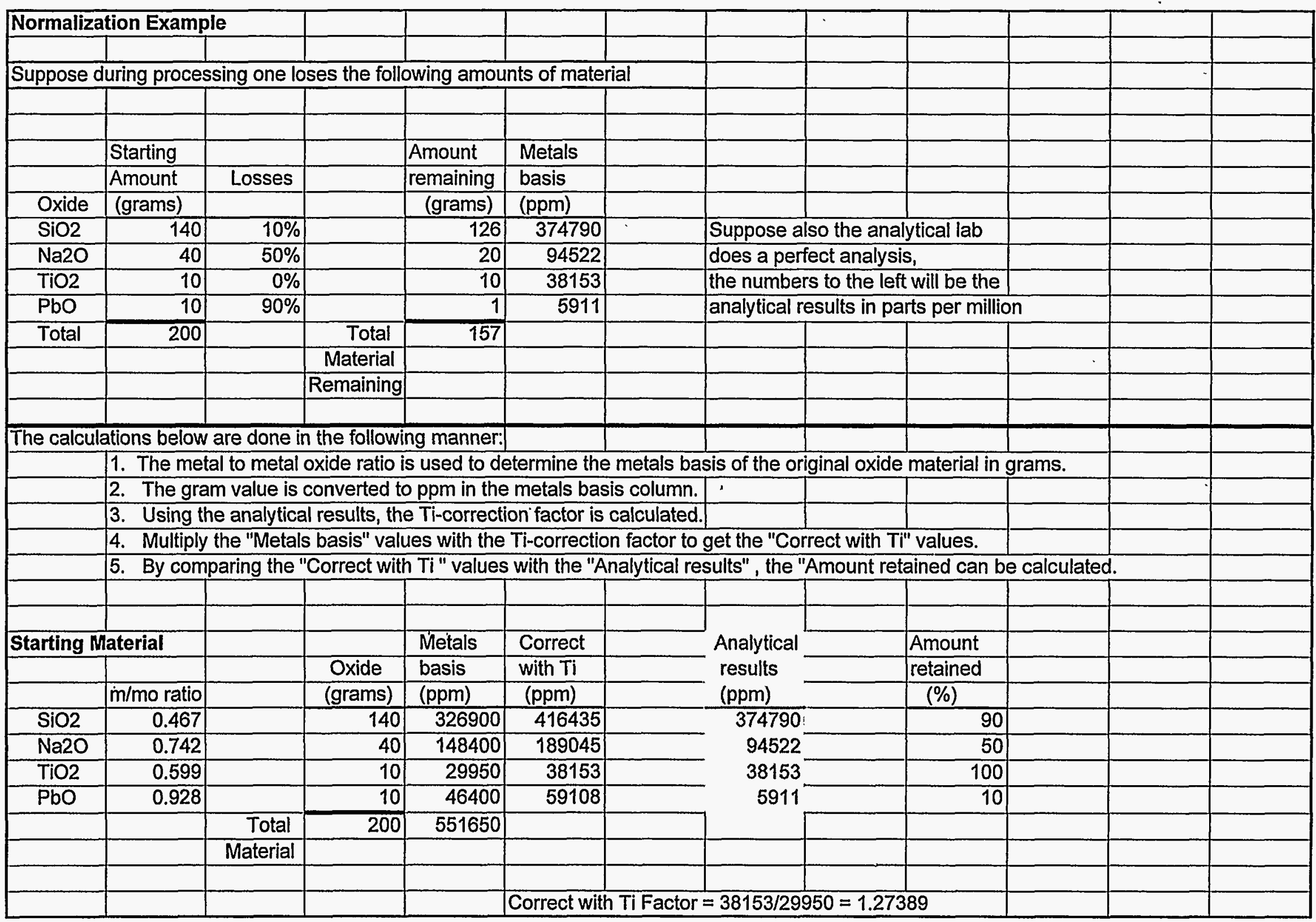


Appendix D

Volatilization Rate Calculations

D-1 


\begin{tabular}{|c|c|c|c|c|c|c|c|}
\hline \multicolumn{7}{|c|}{$\begin{array}{c}\text { IRC ARC MELTER } \\
\text { MULTIPLE METALSPARTICLE EMISSIONS }\end{array}$} & \multirow{2}{*}{$\begin{array}{l}\text { Page } 1 \text { of } 3 \\
\\
\text { 09/20/93 } \\
\text { IRCRUN }\end{array}$} \\
\hline \multicolumn{2}{|c|}{$\begin{array}{l}\text { PLANT: } \\
\text { FACILITY: } \\
\text { SAMPLE LOCATION: }\end{array}$} & $\begin{array}{l}\text { INEL } \\
\text { IRC } \\
\text { IRC MELTER OUTLET }\end{array}$ & \multicolumn{2}{|c|}{$\begin{array}{l}\text { OPERATORS: } \\
\text { ENIERED BY: } \\
\text { CHECKED BY: }\end{array}$} & \multicolumn{2}{|c|}{$\begin{array}{l}\text { HIILARY, GOTSCH } \\
\text { D.M GNOSAR }\end{array}$} & \\
\hline ENTERED DATA & & SYMBOL & UNITS & DATA & DATA & DATA & AVERAGE \\
\hline RUNNUMBER & & - & - & 2 & 3 & 5 & - \\
\hline TEST DATE & & & & $06 / 23 / 93$ & $06 / 24 / 93$ & $07 / 01 / 93$ & \\
\hline TEMPERATURES: & $\begin{array}{l}\text { STACK AVERAGE } \\
\text { MEIER INLET } \\
\text { METER OUILET } \\
\text { METER AVERAGE }\end{array}$ & $\begin{array}{c}\text { Cs } \\
\text { Fmi } \\
\text { Fmo } \\
\text { Fm }\end{array}$ & $\begin{array}{l}\operatorname{deg} C \\
\operatorname{deg} F \\
\operatorname{deg} F \\
\operatorname{deg} F\end{array}$ & $\begin{array}{r}252.2 \\
79.3 \\
76.9 \\
78.1 \\
\end{array}$ & $\begin{array}{r}325.3 \\
77.8 \\
74.7 \\
76.3 \\
\end{array}$ & $\begin{array}{r}257.9 \\
78.5 \\
76.1 \\
77.3 \\
\end{array}$ & \\
\hline PRESSURES: & BAROMETRIC & Pbar & in $\mathrm{Hg}$ & 25.36 & 25.43 & 25.24 & \\
\hline dH (AVERAGE) & & $\mathrm{dH}$ & in $\mathrm{H} 2 \mathrm{O}$ & 0.24 & 1.04 & 0.28 & \\
\hline GAS SAMPLE VOLL & UME & $v_{m}$ & cuft & 9.687 & 10.01 & 10.14 & \\
\hline MEIER CALIBRAT & ION FACTOR & $Y$ & - & 1 & 1 & 1 & \\
\hline SAMPLING TIME (I & TOTAL) & $\min$ & $\min$ & 30 & 17 & 30 & \\
\hline STACX GAS CONTI & $\begin{array}{l}\text { ENT: } \\
\text { OXYGEN } \\
\text { CARBON DIOXIDE }\end{array}$ & $\begin{array}{l}\mathrm{Co} 2 \\
\mathrm{CoO} 2 \\
\end{array}$ & $\begin{array}{l}\% \\
\%\end{array}$ & $\begin{array}{r}21 \\
0 \\
\end{array}$ & $\begin{array}{r}21 \\
0 \\
\end{array}$ & $\begin{array}{r}21 \\
0 \\
\end{array}$ & \\
\hline $\begin{array}{l}\text { WATER COLLECTE } \\
\text { FILIER CATCH }\end{array}$ & & $\begin{array}{l}\text { Whe } \\
\text { Wi }\end{array}$ & $\begin{array}{l}\mathrm{gm} \\
\mathrm{mg}\end{array}$ & $\begin{array}{l}73.2 \\
2370 \\
\end{array}$ & $\begin{array}{r}61.59 \\
1171 \\
\end{array}$ & $\begin{array}{l}52.2 \\
1849 \\
\end{array}$ & \\
\hline METALS CATCH: & $\begin{array}{l}\text { VOL OF ANALYZED SAMPLE } \\
\text { CADMIUM } \\
\text { CERIUM } \\
\text { CESIUM } \\
\text { CHROMIUM (TOTAL) } \\
\text { GADOLINIUM } \\
\text { LEAD } \\
\text { NEODYMIIM } \\
\text { SAMARIUM } \\
\text { ZINC }\end{array}$ & $\begin{array}{l}\text { vi } \\
\text { CCd } \\
C C e \\
C C s \\
C C r \\
C G d \\
\text { Cpt } \\
\text { CNd } \\
\text { CSm } \\
\text { CZn }\end{array}$ & 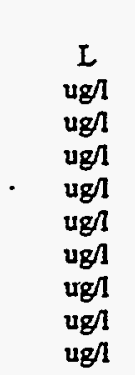 & $\begin{array}{r}0.25 \\
947,000 \\
6,230 \\
164,000 \\
3,260 \\
10,100 \\
1,360,000 \\
9,240 \\
6,980 \\
991,000\end{array}$ & $\begin{array}{r}0.25 \\
449,000 \\
5,690 \\
73,900 \\
2,260 \\
10,700 \\
473,000 \\
12,200 \\
7,560 \\
581,000\end{array}$ & $\begin{array}{r}0.25 \\
666,000 \\
4,240 \\
124,000 \\
8,620 \\
5,490 \\
713,000 \\
5,580 \\
5,120 \\
574,000\end{array}$ & \\
\hline
\end{tabular}


PLANT: INEL

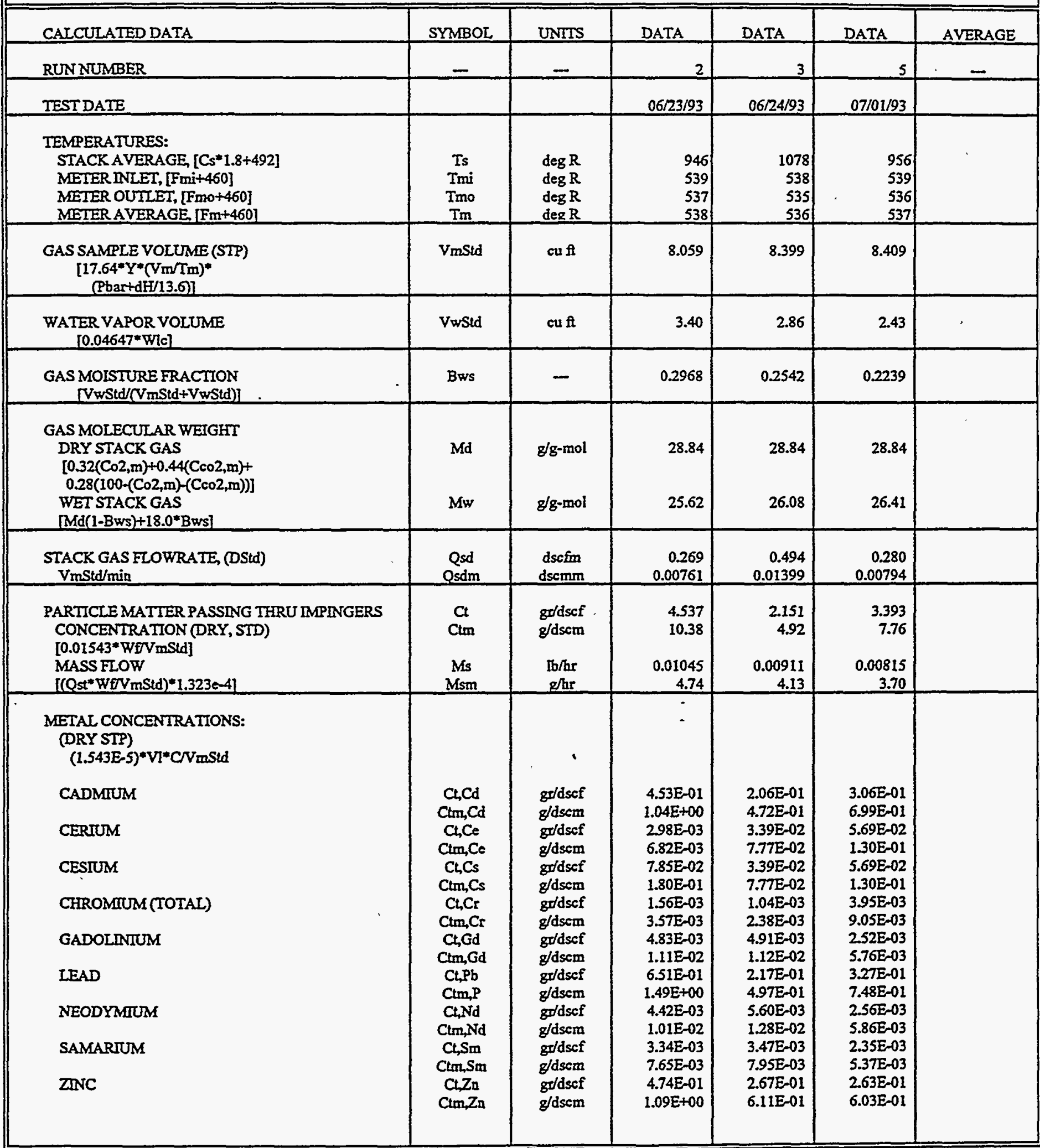


PLANT: INEL

\begin{tabular}{|c|c|c|c|c|c|c|}
\hline CALCULATED DATA & SYMBOL & UNTTS & DATA & DATA & DATA & AVERAGE \\
\hline RUN NUMBER & - & $=$ & 2 & 3 & 5 & $=$ \\
\hline IEST DATE & & & $06 / 23 / 93$ & $06 / 24 / 93$ & 07/01/93 & \\
\hline \multicolumn{7}{|c|}{$\begin{array}{l}\text { METAL MASS FLOWS: } \\
\text { (DRY, STP) } \\
{\left[(1.323 \mathrm{E}-7)^{*} \mathrm{~V}^{\star} \mathrm{C}^{\star} \mathrm{Qsd} / \mathrm{VmStd}\right]}\end{array}$} \\
\hline CADMIUM & $\mathrm{M}, \mathrm{Cd}$ & $\mathrm{Ib} / \mathrm{hr}$ & $1.04 \mathrm{E}-03$ & 8.74E-04 & 7.34E-04 & \\
\hline CERIUM & $\mathrm{M}, \mathrm{Ce}$ & $\mathrm{Ib} / \mathrm{hr}$ & $6.87 \mathrm{E}-06$ & 1.11E-05 & 4.67E-06 & \\
\hline & & $\mathrm{kg} / \mathrm{hr}$ & $3.12 \mathrm{E}-06$ & $5.02 \mathrm{E}-06$ & $2.12 E-06$ & \\
\hline CESIUM & $\mathrm{M}, \mathrm{Cs}$ & $\mathrm{Ib} / \mathrm{hr}$ & $1.81 E-04$ & $1.44 \mathrm{E}-04$ & 1.37E-04 & \\
\hline & & $\mathrm{kg} / \mathrm{hr}$ & $8.20 \mathrm{E}-05$ & $6.52 \mathrm{E}-05$ & $6.20 \mathrm{E}-05$ & \\
\hline CHROMUUM (TOTAL) & $\mathrm{M}, \mathrm{Cr}$ & $\mathrm{lb} / \mathrm{hr}$ & $3.59 \mathrm{E}-06$ & 4.40E-06 & $9.50 \mathrm{E}-06$ & \\
\hline & & $\mathrm{kg} / \mathrm{hr}$ & $1.63 \mathrm{E}-06$ & 1.99E-06 & 4.31E-06 & \\
\hline GADOLINIUM & $M, G d$ & $\mathrm{~Tb} / \mathrm{hr}$ & 1.11E-05 & 2.08E-05 & 6.05E-06 & \\
\hline & & $\mathrm{kg} / \mathrm{hr}$ & 5.05E-06 & $9.44 \mathrm{E}-06$ & 2.75E-06 & \\
\hline LEAD & $\mathrm{M}, \mathrm{Pb}$ & $\begin{array}{l}\mathrm{lb} / \mathrm{hr} \\
\mathrm{kg} / \mathrm{hr}\end{array}$ & $\begin{array}{l}1.50 \mathrm{E}-03 \\
6.80 \mathrm{E}-04\end{array}$ & $\begin{array}{l}9.20 E-04 \\
4.17 E-04\end{array}$ & $\begin{array}{l}7.86 \mathrm{E}-04 \\
3.57 \mathrm{E}-04\end{array}$ & \\
\hline NEODYMIUM & M,Nd & $\mathrm{Ib} / \mathrm{hr}$ & $1.02 E-05$ & 2.37E-05 & 6.15E-06 & \\
\hline SAMARTUM & M,Sm & $\begin{array}{l}\mathrm{kg} / \mathrm{hr} \\
\mathrm{lb} / \mathrm{hr}\end{array}$ & $\begin{array}{l}\text { 4.62E-06 } \\
7.70 \mathrm{E}-06\end{array}$ & $\begin{array}{l}1.08 E-05 \\
1.47 E-05\end{array}$ & $\begin{array}{l}2.79 \mathrm{E}-06 \\
5.64 \mathrm{E}-06\end{array}$ & \\
\hline ZnNC & $M, Z n$ & $\begin{array}{l}\mathrm{kg} / \mathrm{hr} \\
\mathrm{Ib} / \mathrm{hr} \\
\mathrm{kg} / \mathrm{hr}\end{array}$ & $\begin{array}{l}3.49 \mathrm{E}-06 \\
1.09 \mathrm{E}-03 \\
4.96 \mathrm{E}-04\end{array}$ & $\begin{array}{l}6.67 \mathrm{E}-06 \\
1.13 \mathrm{E}-03 \\
5.13 \mathrm{E}-04\end{array}$ & $\begin{array}{l}2.56 \mathrm{E}-06 \\
6.33 \mathrm{E}-04 \\
2.87 \mathrm{E}-04\end{array}$ & \\
\hline
\end{tabular}




\begin{tabular}{|c|c|c|c|c|c|c|c|}
\hline \multicolumn{7}{|c|}{$\begin{array}{l}\text { IRC ARC MELTER } \\
\text { MULTIPLE METALS/PARTCLE EMISSIONS }\end{array}$} & \multirow{2}{*}{$\begin{array}{l}\text { Page } 1 \text { of } 3 \\
\text { 09/20/93 } \\
\text { RRCRUN2 }\end{array}$} \\
\hline \multicolumn{2}{|c|}{$\begin{array}{l}\text { PLANT: } \\
\text { FACILITY: } \\
\text { SAMPLE LOCATION: }\end{array}$} & $\begin{array}{l}\text { INEL } \\
\text { IRC } \\
\text { IRC MEL TER OUILET }\end{array}$ & \multicolumn{2}{|c|}{$\begin{array}{l}\text { OPERATORS: } \\
\text { ENTERED BY: } \\
\text { CHECKED BY: }\end{array}$} & \multicolumn{2}{|c|}{$\begin{array}{l}\text { HIILIARY, GOTSCH } \\
\text { D. M. GINOSAR }\end{array}$} & \\
\hline ENTERED DATA & & SYMBOL & UNTIS & DATA & DATA & DATA & AVERAGE \\
\hline RUN NUMBER & & - & - & 6 & 6 & & - \\
\hline TEST DATE & & & & 07/02/93 & 07/02/93 & & \\
\hline $\begin{array}{r}\text { TEMPERATURES: } \\
\text { ST } \\
\text { M } \\
\text { M } \\
\end{array}$ & $\begin{array}{l}\text { SACK AVERAGE } \\
\text { METER INLET } \\
\text { METER OUTLET } \\
\text { IETER AVERAGE }\end{array}$ & $\begin{array}{c}\text { Cs } \\
\text { Fmi } \\
\text { Fmo } \\
\text { Fm } \\
\end{array}$ & $\begin{array}{l}\operatorname{deg} C \\
\operatorname{deg} F \\
\operatorname{deg} F \\
\operatorname{deg} F \\
\end{array}$ & $\begin{array}{r}193.0 \\
77.0 \\
75.0 \\
76.0 \\
\end{array}$ & \begin{tabular}{r|}
149.9 \\
79.5 \\
78.3 \\
78.9 \\
\end{tabular} & & $\begin{array}{r}171.5 \\
78.3 \\
76.7 \\
77.5 \\
\end{array}$ \\
\hline PRESSURES: & BAROMETRIC & Pbar & in $\mathrm{Hg}$ & 25.19 & 25.19 & & 25.2 \\
\hline dH (AVERAGE) & & $\mathrm{dH}$ & in $\mathrm{H} 2 \mathrm{O}$ & 0.33 & 0.19 & & 0.3 \\
\hline GAS SAMPLE VOLU & UME & $\mathrm{Vm}_{\mathrm{m}}$ & cuft & 4 & 2.4 & & 3.2 \\
\hline METER CAIIBRATI & ION FACTOR & $Y$ & - & 1 & 1 & & 1.0 \\
\hline SAMPLING TIME (T & rOTAL) & $\min$ & $\min$ & 11 & 9 & & 10.0 \\
\hline $\begin{array}{r}\text { STACK GAS CONTE } \\
0 \\
\mathrm{C} \\
\end{array}$ & $\begin{array}{l}\text { ENT: } \\
\text { OXYGEN } \\
\text { CARBON DIOXIDE }\end{array}$ & $\begin{array}{r}\mathrm{Co} 2 \\
\mathrm{C} 02 \\
\end{array}$ & $\begin{array}{l}\% \\
\% \\
\end{array}$ & $\begin{array}{r}21 \\
0 \\
\end{array}$ & $\begin{array}{r}21 \\
0 \\
\end{array}$ & & 21.0 \\
\hline $\begin{array}{l}\text { WATER COLLECTEI } \\
\text { FLTER CATCH }\end{array}$ & & $\begin{array}{l}\text { Whe } \\
\text { Wf }\end{array}$ & $\begin{array}{c}\mathrm{gm} \\
\mathrm{mg}\end{array}$ & $\begin{array}{r}10.81 \\
729 \\
\end{array}$ & $\begin{array}{l}1.9 \\
248 \\
\end{array}$ & & $\begin{array}{r}6.4 \\
488.2 \\
\end{array}$ \\
\hline METALS CATCH: & $\begin{array}{l}\text { VOL OF ANALYZED SAMPLE } \\
\text { CADMIUM } \\
\text { CERUM } \\
\text { CESIUM } \\
\text { CHROMUM (TOTAL) } \\
\text { GADOLINIUM } \\
\text { LEAD } \\
\text { NEODYMIUM } \\
\text { SAMARUM } \\
\text { ZINC }\end{array}$ & $\begin{array}{l}\mathrm{Vl} \\
\mathrm{CCd} \\
\mathrm{CCe} \\
\mathrm{CCs} \\
\mathrm{CCr} \\
\mathrm{CGd} \\
\mathrm{CPb} \\
\mathrm{CNd} \\
\mathrm{CSm} \\
\mathrm{CZn}\end{array}$ & 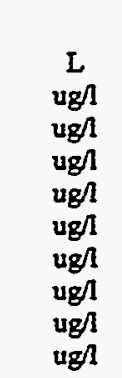 & $\begin{array}{r}0.25 \\
206,000 \\
1,410 \\
99,000 \\
12,300 \\
1,850 \\
162,000 \\
1,790 \\
1,770 \\
338,000\end{array}$ & $\begin{array}{r}0.25 \\
191,000 \\
500 \\
12,000 \\
8,880 \\
500 \\
25,500 \\
500 \\
500 \\
32,000\end{array}$ & & $\begin{array}{r}0.25 \\
198,500 \\
955 \\
55,500 \\
10,590 \\
1,175 \\
93,750 \\
1,145 \\
1,135 \\
185,000\end{array}$ \\
\hline
\end{tabular}


PLANT: INEI

\begin{tabular}{|c|c|c|c|c|c|c|}
\hline CALCULATED DATA & SYMBOL & UNITS & DATA & DATA & DATA & AVERAGE \\
\hline RUNNUMBER & $=$ & - & 6 & 6 & & $=$ \\
\hline TEST DATE & & & $07 / 02 / 93$ & $07 / 02 / 93$ & & \\
\hline $\begin{array}{l}\text { TEMPERATURES: } \\
\text { STACK AVERAGE, [Cs*1.8+492] } \\
\text { METER INLET, [Fmi+460] } \\
\text { METER OUTLET, [Fmo+460] } \\
\text { METER AVERAGE. [Fm+460] }\end{array}$ & $\begin{array}{l}\text { Ts } \\
\text { Tmi } \\
T m o \\
T m\end{array}$ & $\begin{array}{l}\operatorname{deg} R \\
\operatorname{deg} R \\
\operatorname{deg} R \\
\operatorname{deg} R\end{array}$ & $\begin{array}{l}839 \\
537 \\
535 \\
536 \\
\end{array}$ & $\begin{array}{l}762 \\
540 \\
538 \\
539 \\
\end{array}$ & & $\begin{array}{l}801 \\
538 \\
537 \\
537\end{array}$ \\
\hline $\begin{array}{l}\text { GAS SAMPLE VOLUME (STP) } \\
{\left[\begin{array}{c}\text { [17.64* } \\
\text { (Pbartd }(\mathrm{Vm} / 13.6 \mathrm{Tm})\end{array}\right.}\end{array}$ & VmStd & cu $f t$ & 3.319 & 1.980 & & 2.648 \\
\hline $\begin{array}{l}\text { WATER VAPOR VOLUME } \\
{\left[0.04647^{*} \text { Wic] }\right.}\end{array}$ & Vwstd & cu $\mathrm{ft}$ & 0.50 & 0.09 & & 0.30 \\
\hline $\begin{array}{l}\text { GAS MOISTURE FRACTION } \\
{\left[V_{w S t d}\left(V_{\text {mStd }}+V_{w S t d}\right]\right.}\end{array}$ & Bws & - & 0.1314 & 0.0427 & & 0.1003 \\
\hline $\begin{array}{l}\text { GÁS MOLECULAR WEIGHT } \\
\text { DRY STACK GAS } \\
{[0.32(\mathrm{Co} 2, \mathrm{~m})+0.44(\mathrm{Cco} 2, \mathrm{~m})+} \\
0.28(100-(\mathrm{Co} 2, \mathrm{~m})-(\mathrm{Cco} 2, \mathrm{~m}))] \\
\text { WET STACK GAS } \\
\text { [Md(1-Bws)+18.0*Bws] }\end{array}$ & $M w$ & $\begin{array}{l}\text { g/g-mol } \\
g / g-m o l\end{array}$ & $\begin{array}{l}28.84 \\
27.42\end{array}$ & $\begin{array}{l}28.84 \\
28.38\end{array}$ & & $\begin{array}{l}28.84 \\
27.75\end{array}$ \\
\hline $\begin{array}{l}\text { STACK GAS FLOWRATE, (DStd) } \\
V_{\text {mStd/min }}\end{array}$ & $\begin{array}{l}\text { Qsd } \\
\text { Qsdm }\end{array}$ & $\begin{array}{l}\text { dsefm } \\
\text { dscmm }\end{array}$ & $\begin{array}{r}0.302 \\
0.00855 \\
\end{array}$ & $\begin{array}{r}0.220 \\
0.00623 \\
\end{array}$ & & $\begin{array}{r}0.265 \\
0.00750 \\
\end{array}$ \\
\hline $\begin{array}{l}\text { PARTICLE MATTER PASSING THRU IMPINGERS } \\
\text { CONCENTRATION (DRY, STD) } \\
\text { [0.01543*WOVmStd] } \\
\text { MASS FLOW } \\
\left.\text { [QSt"WRVmStd) }{ }^{*} 1.323 e-4\right]\end{array}$ & $\begin{array}{c}\mathrm{Ct} \\
\mathrm{Ctm} \\
\mathrm{Mss} \\
\mathrm{Msm}\end{array}$ & $\begin{array}{l}\text { gddsef } \\
\text { g/dscm } \\
\mathrm{Ib} / \mathrm{hr} \\
\mathrm{g} / \mathrm{hr}\end{array}$ & $\begin{array}{r}3.387 \\
7.75 \\
0.00876 \\
3.97 \\
\end{array}$ & $\begin{array}{r}1.931 \\
4.42 \\
0.00364 \\
1.65 \\
\end{array}$ & & $\begin{array}{r}2.845 \\
6.51 \\
0.00646 \\
2.93 \\
\end{array}$ \\
\hline $\begin{array}{l}\text { METAL CONCENTRATIONS: } \\
\text { (DRY STP) } \\
(1.543 E-5) * I^{*} \text { CVmStd }\end{array}$ & & & - & & & \\
\hline $\begin{array}{l}\text { CADMIUM } \\
\text { CERIUM } \\
\text { CESIUM } \\
\text { CHROMIUM (TOTAL) } \\
\text { GADOLINIUM } \\
\text { LEAD } \\
\text { NEODYMIUM } \\
\text { SAMARIIM } \\
\text { ZNNC }\end{array}$ & $\begin{array}{c}C t, C d \\
C t m, C d \\
C t, C e \\
C t m, C e \\
C t, C s \\
C t m, C s \\
C t, C r \\
C t m, C r \\
C t, G d \\
C t m, G d \\
C t, P b \\
C t m, P \\
C t, N d \\
C t m, N d \\
C t, S m \\
C t m, S m \\
C t, Z a \\
C t m, Z a\end{array}$ & 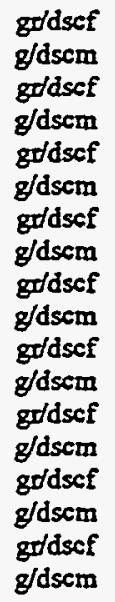 & $\begin{array}{l}2.39 \mathrm{E}-01 \\
5.48 \mathrm{E}-01 \\
1.64 \mathrm{E}-03 \\
3.75 \mathrm{E}-03 \\
1.15 \mathrm{E}-01 \\
2.63 \mathrm{E}-01 \\
1.43 \mathrm{E}-02 \\
3.27 \mathrm{E}-02 \\
2.15 \mathrm{E}-03 \\
4.92 \mathrm{E}-03 \\
1.88 \mathrm{E}-01 \\
4.31 \mathrm{E}-01 \\
2.08 \mathrm{E}-03 \\
4.76 \mathrm{E}-03 \\
2.06 \mathrm{E}-03 \\
4.71 \mathrm{E}-03 \\
3.93 \mathrm{E}-01 \\
8.99 \mathrm{E}-01\end{array}$ & $\begin{array}{l}3.72 \mathrm{E}-01 \\
8.52 \mathrm{E}-01 \\
2.34 \mathrm{E}-02 \\
5.35 \mathrm{E}-02 \\
2.34 \mathrm{E}-02 \\
5.35 \mathrm{E}-02 \\
1.73 \mathrm{E}-02 \\
3.96 \mathrm{E}-02 \\
9.74 \mathrm{E}-04 \\
2.23 \mathrm{E}-03 \\
4.97 \mathrm{E}-02 \\
1.14 \mathrm{E}-01 \\
9.74 \mathrm{E}-04 \\
2.23 \mathrm{E}-03 \\
9.74 \mathrm{E}-04 \\
2.23 \mathrm{E}-03 \\
6.23 \mathrm{E}-02 \\
1.43 \mathrm{E}-01\end{array}$ & $\because$, & $\begin{array}{r}2.89 \mathrm{E}-01 \\
6.62 \mathrm{E}-01 \\
8.09 \mathrm{E}-02 \\
1.85 \mathrm{E}-01 \\
8.09 \mathrm{E}-02 \\
1.850 \mathrm{E}-01 \\
1.54 \mathrm{E}-02 \\
3.531 \mathrm{E}-02 \\
1.71 \mathrm{E}-03 \\
3.917 \mathrm{E}-03 \\
1.37 \mathrm{E}-01 \\
3.13 \mathrm{E}-01 \\
1.67 \mathrm{E}-03 \\
3.817 \mathrm{E}-03 \\
1.65 \mathrm{E}-03 \\
3.784 \mathrm{E}-03 \\
2.70 \mathrm{E}-01 \\
6.168 \mathrm{E}-01\end{array}$ \\
\hline
\end{tabular}




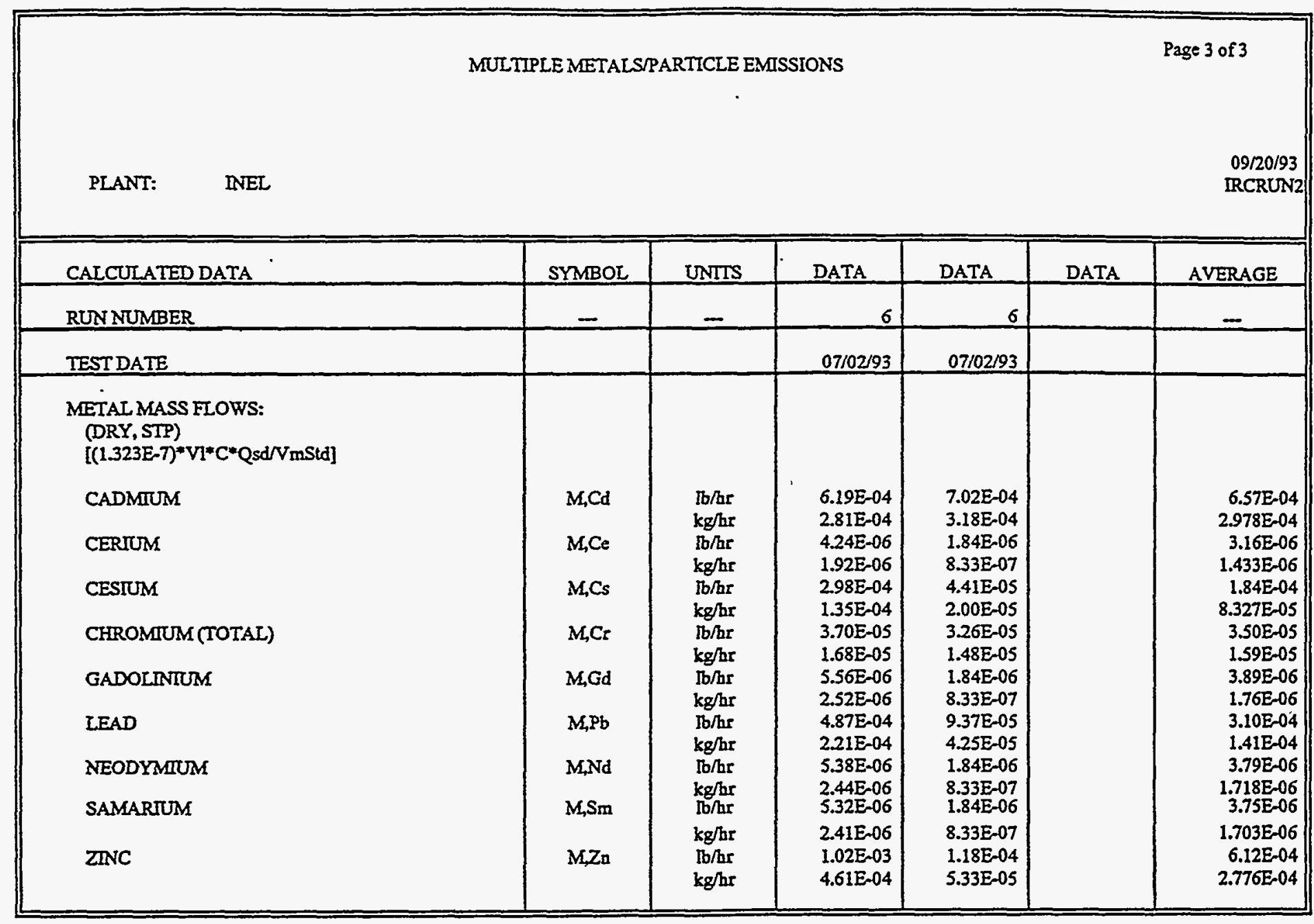




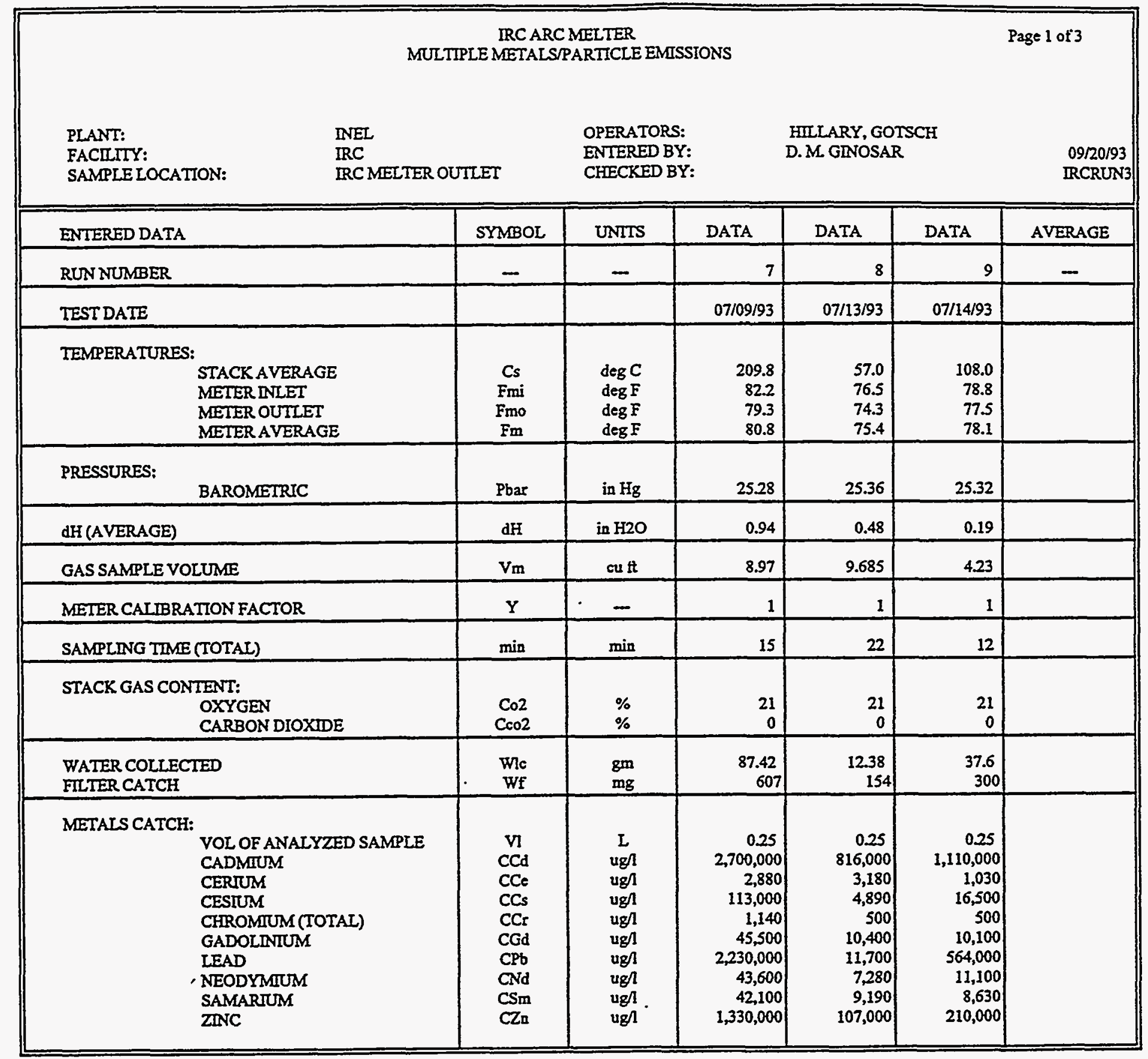


PLANT: INEL

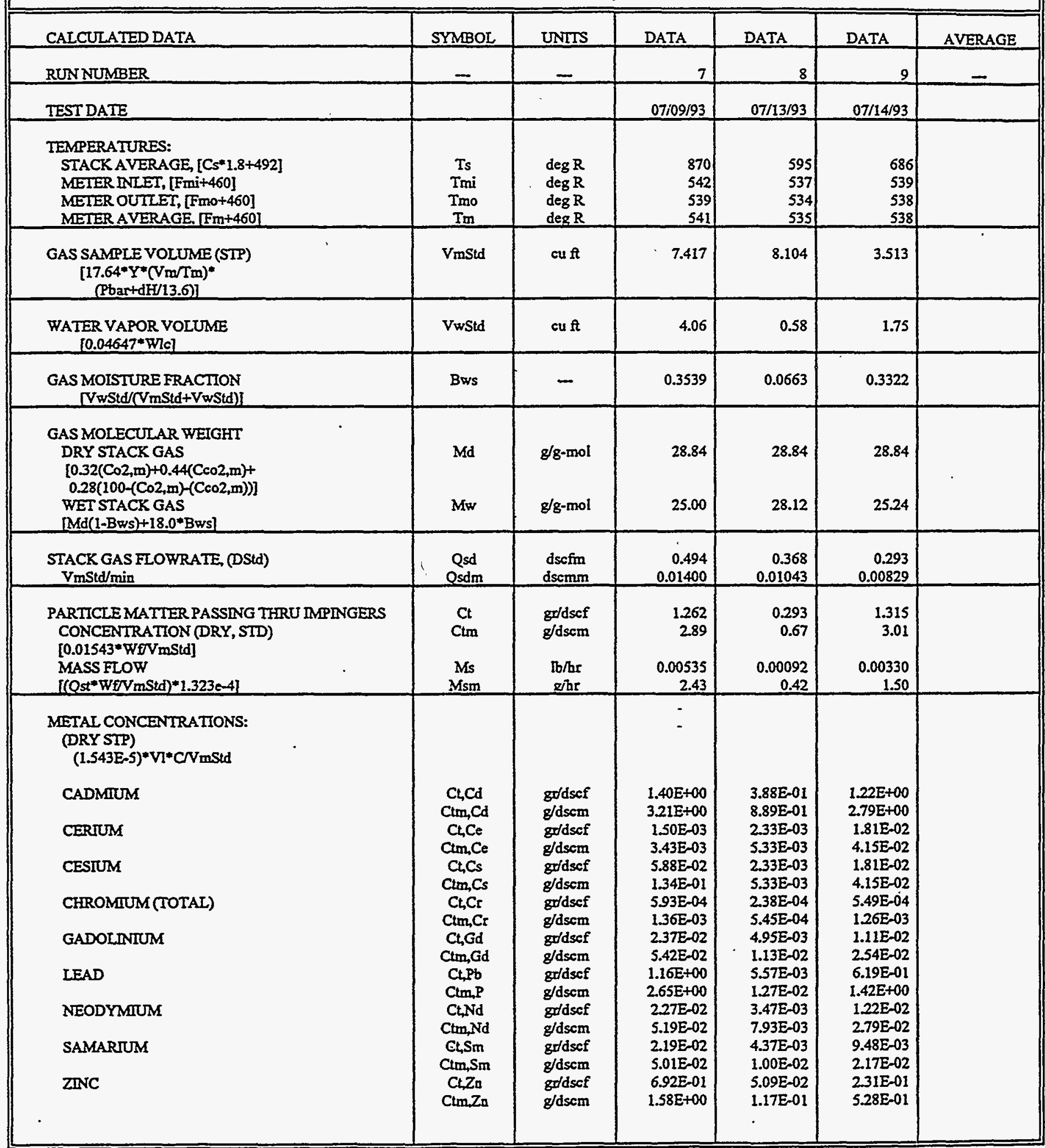




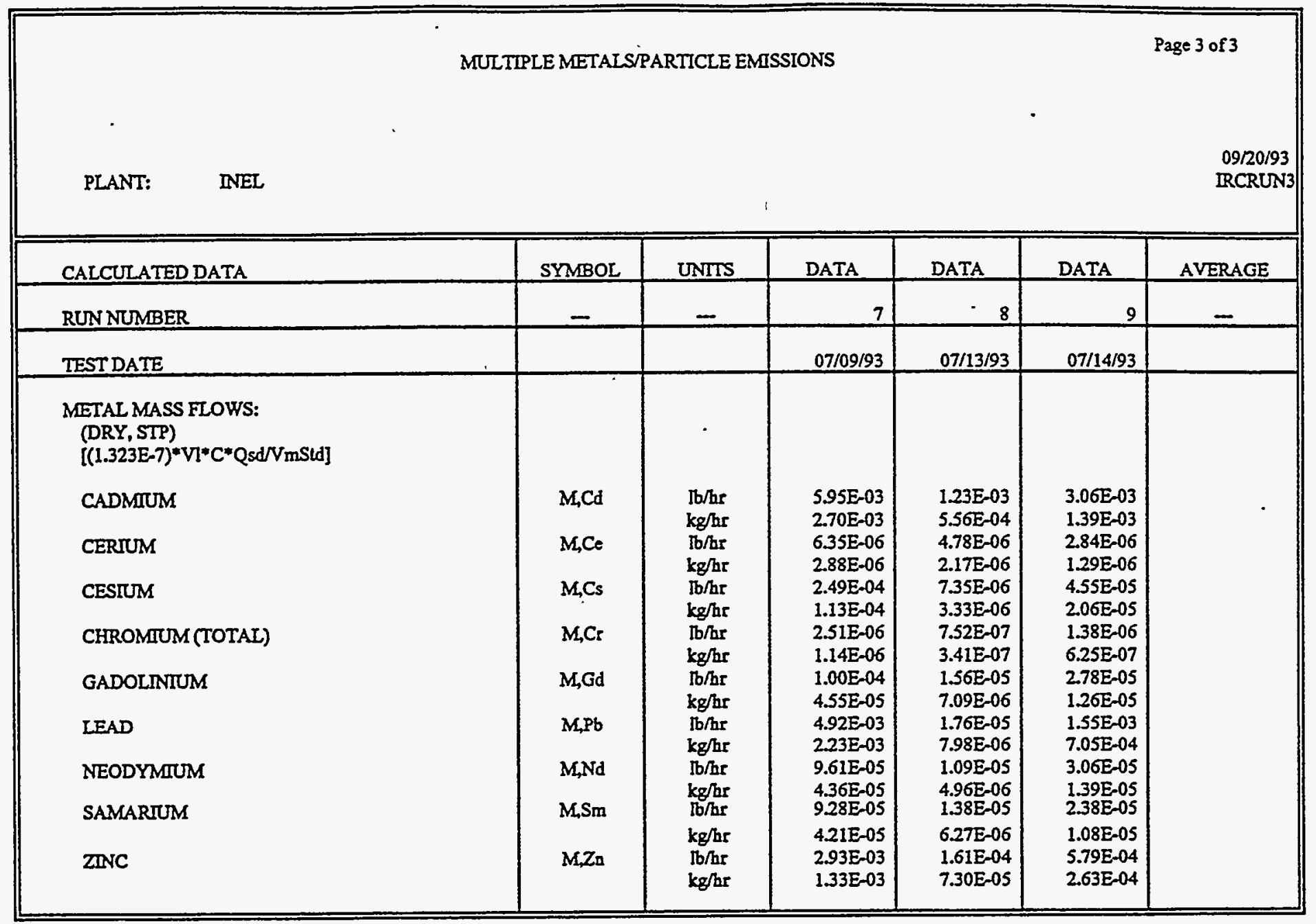




\begin{tabular}{|c|c|c|c|c|c|c|c|}
\hline \multicolumn{7}{|c|}{$\begin{array}{c}\text { IRC ARC MELTER } \\
\text { MUITIPLE METALSTPARTICLE EMISSIONS }\end{array}$} & \multirow{3}{*}{$\begin{array}{r}\text { Page I of } 3 \\
\text { 09/20/93 } \\
\text { IRCRUN } \\
\text { AVERAGE }\end{array}$} \\
\hline \multicolumn{2}{|c|}{$\begin{array}{l}\text { PLANT: } \\
\text { FACIIIY: } \\
\text { SAMPLE LOCATION: }\end{array}$} & $\begin{array}{l}\text { INEL } \\
\text { IRC } \\
\text { IRC MELTER OUTLET }\end{array}$ & \multicolumn{2}{|c|}{$\begin{array}{l}\text { OPERATORS: } \\
\text { ENTERED BY: } \\
\text { CHECKED BY: }\end{array}$} & \multicolumn{2}{|c|}{$\begin{array}{l}\text { GOTSCH } \\
\text { D.M. GINOSAR }\end{array}$} & \\
\hline ENTERED DATA & & SYMBOL & UNITS & DATA & DATA & DATA & \\
\hline RUN NUMBER & - & - & - & 10 & & & - \\
\hline TEST DATE & & & & 07/16/93 & & & \\
\hline TEMPERATURES: & $\begin{array}{l}\text { STACK AVERAGE } \\
\text { METER INLET } \\
\text { METER OUTLET } \\
\text { METER AVERAGE }\end{array}$ & $\begin{array}{l}\mathrm{Cs} \\
\text { Fmi } \\
\text { Fmo } \\
\text { Fm }\end{array}$ & $\begin{array}{l}\operatorname{deg} C \\
\operatorname{deg} F \\
\operatorname{deg} F \\
\operatorname{deg} F\end{array}$ & $\begin{array}{r}107.3 \\
77.5 \\
76.0 \\
76.8 \\
\end{array}$ & & & \\
\hline PRESSURES: & BAROMEIRIC & Pbar & in $\mathrm{Hg}$ & 25.38 & & & \\
\hline dH (AVERAGE) & & $\mathrm{dH}$ & in $\mathrm{H} 2 \mathrm{O}$ & 0.29 & & & \\
\hline GAS SAMPLE VOLU & UME & $\mathrm{V}_{\mathrm{m}}$ & coutt & 7.545 & & & \\
\hline MEIER CAIIBRATI & IION FACTOR & $Y$ & - & 1 & & & \\
\hline SAMPLING TIME (I & TOTAL) & $\min$ & $\min$ & 21 & & & \\
\hline STACK GAS CONTE & $\begin{array}{l}\text { CENT: } \\
\text { OXYGEN } \\
\text { CARBON DIOXIEE }\end{array}$ & $\begin{array}{l}\mathrm{Co2} \\
\mathrm{CoO} 2 \\
\end{array}$ & $\%$ & $\begin{array}{r}21 \\
0 \\
\end{array}$ & & & \\
\hline $\begin{array}{l}\text { WATER COLIECTE } \\
\text { FILTER CATCH }\end{array}$ & & $\begin{array}{l}\text { Wle } \\
\text { WE }\end{array}$ & $\begin{array}{l}\mathrm{gm} \\
\mathrm{mg}\end{array}$ & $\begin{array}{r}126.9 \\
414 \\
\end{array}$ & & & \\
\hline $\begin{array}{r}\text { METALS CATCH: } \\
\text { V } \\
\text { C } \\
\text { C } \\
\text { C } \\
\text { C } \\
\text { C } \\
\text { I } \\
\text { N } \\
\text { S } \\
\text { Z }\end{array}$ & $\begin{array}{l}\text { VOL OF ANALYZED SAMPLE } \\
\text { CADMUM } \\
\text { CERIUM } \\
\text { CESIUM } \\
\text { CEROMIUM(TOTAL) } \\
\text { GADOLINUM } \\
\text { IEAD } \\
\text { NEODYMIUM } \\
\text { SAMARIMM } \\
\text { ZINC }\end{array}$ & $\begin{array}{l}\mathrm{v} \\
\mathrm{CCd} \\
\mathrm{CCe} \\
\mathrm{CCs} \\
\mathrm{CCr} \\
\mathrm{CGd} \\
\mathrm{CPb} \\
\mathrm{CNd} \\
\mathrm{CSm} \\
\mathrm{CZn}\end{array}$ & $\begin{array}{l}\mathrm{L} \\
\mathrm{ug} / 1 \\
\mathrm{ug} / 1 \\
\mathrm{ug} / 1 \\
\mathrm{ugl} \\
\mathrm{ugl} \\
\mathrm{ugl} \\
\mathrm{ugl} \\
\mathrm{ugl} \\
\mathrm{ug} /\end{array}$ & $\begin{array}{r}0.25 \\
1,580,000 \\
5,920 \\
65,500 \\
500 \\
94,400 \\
141,000 \\
114,000 \\
91,300 \\
176,000\end{array}$ & & & \\
\hline
\end{tabular}









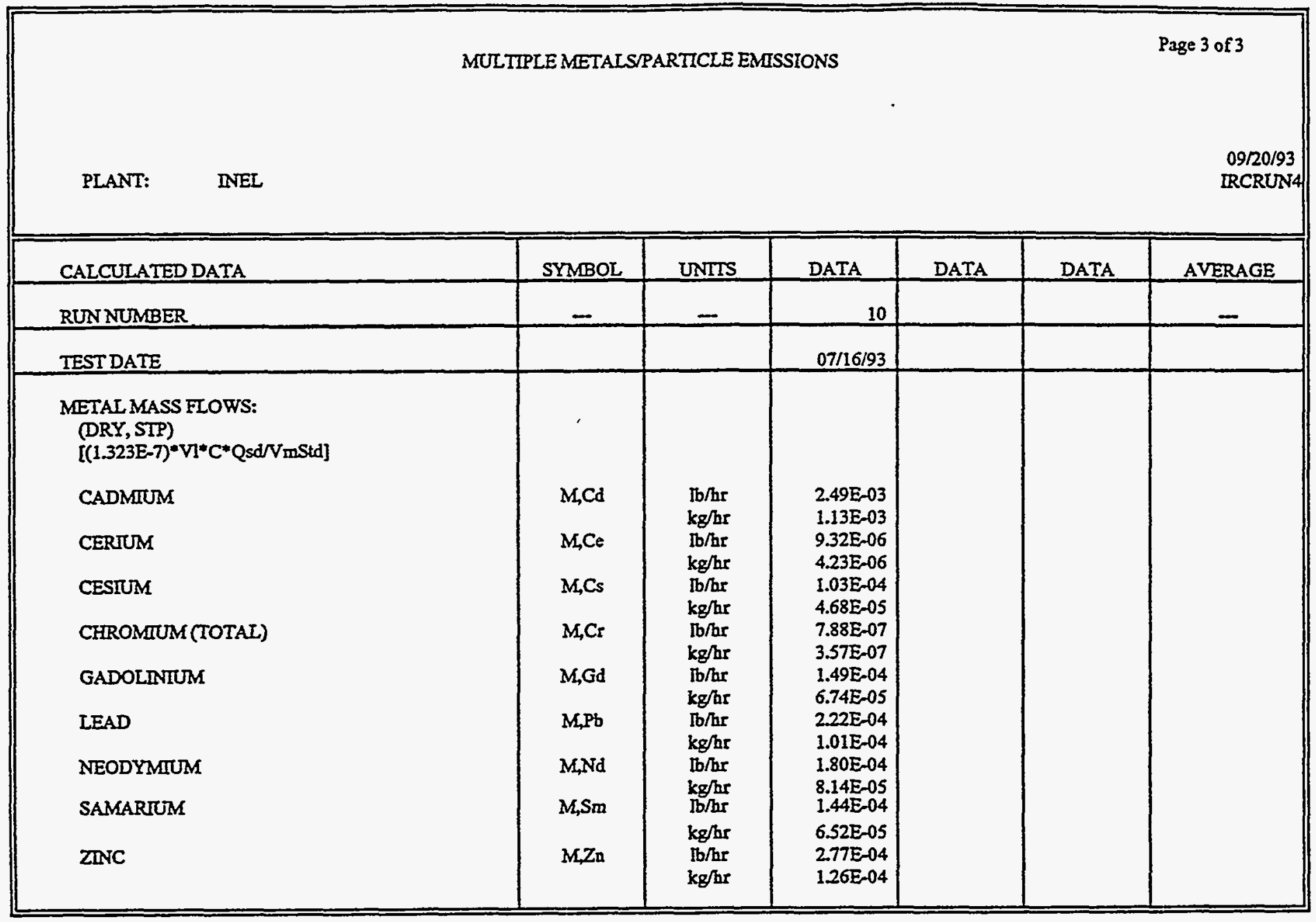


Appendix E

EDXS and XRF Data

E-1 
Filter Particulate Analysis - ARM082394.

\begin{tabular}{|c|c|l|l|l|}
\hline Element & XRF 4.1 & XRF 5.1 & EDXS \#1 & EDXS \#3 \\
\hline $\mathrm{Mg}$ & 0 & 0 & 0 & 0 \\
\hline $\mathrm{Al}$ & 0 & 0 & 0 & 2900 \\
\hline $\mathrm{Si}$ & 38300 & 84300 & 35500 & 139000 \\
\hline $\mathrm{K}$ & 15900 & 18000 & 0 & 37300 \\
\hline $\mathrm{Ca}$ & 2800 & 4600 & 0 & 2900 \\
\hline $\mathrm{Ti}$ & 3000 & 5700 & 0 & 5400 \\
\hline $\mathrm{Fe}$ & 45600 & 75900 & 16100 & 39100 \\
\hline $\mathrm{Zn}$ & 204300 & 156300 & 129800 & 261000 \\
\hline $\mathrm{Zr}$ & 611 & 1900 & 0 & 0 \\
\hline $\mathrm{Cd}$ & 237000 & 78000 & 240200 & 99100 \\
\hline $\mathrm{Cs}$ & 12700 & 13800 & 18100 & 28300 \\
\hline $\mathrm{Ce}$ & 442 & 1300 & 0 & 0 \\
\hline $\mathrm{Sm}$ & 785 & 2100 & 0 & 0 \\
\hline $\mathrm{Pb}$ & 232100 & 18400 & 261600 & 159500 \\
\hline
\end{tabular}


Filter Particulate Analysis - ARM082694.

\begin{tabular}{|c|c|l|l|l|}
\hline Element & XRF 4.1 & XRF 5.1 & EDXS \#1 & EDXS \#3 \\
\hline $\mathrm{Mg}$ & 0 & 0 & 0 & 2600 \\
\hline $\mathrm{Al}$ & 0 & 0 & 0 & 3400 \\
\hline $\mathrm{Si}$ & 33800 & 111300 & 40200 & 109500 \\
\hline $\mathrm{K}$ & 11200 & 32300 & 34300 & 29800 \\
\hline $\mathrm{Ca}$ & 1500 & 12600 & 0 & 7900 \\
\hline $\mathrm{Ti}$ & 2600 & 3000 & 0 & 9800 \\
\hline $\mathrm{Fe}$ & 22400 & 27900 & 22600 & 52800 \\
\hline $\mathrm{Zn}$ & 179700 & 150300 & 153300 & 85000 \\
\hline $\mathrm{Zr}$ & 741 & 654 & 0 & 0 \\
\hline $\mathrm{Cd}$ & 157600 & 33200 & 216700 & 109400 \\
\hline $\mathrm{Cs}$ & 14700 & 3000 & 27100 & 25000 \\
\hline $\mathrm{Ce}$ & 381 & 775 & 0 & 0 \\
\hline $\mathrm{Sm}$ & 786 & 1100 & 0 & 0 \\
\hline $\mathrm{Pb}$ & 174700 & 146000 & 191600 & 149000 \\
\hline
\end{tabular}


Filter Particulate Analysis - ARM090694.

\begin{tabular}{|c|c|c|c|c|c|c|c|c|}
\hline Element & $\begin{array}{c}\text { XRF } \\
4.1\end{array}$ & $\begin{array}{c}\text { XRF } \\
5.1\end{array}$ & $\begin{array}{c}\text { EDXS } \\
\text { F1 }\end{array}$ & $\begin{array}{c}\text { EDXS } \\
\text { F2 }\end{array}$ & $\begin{array}{c}\text { EDXS } \\
\text { F3 }\end{array}$ & $\begin{array}{c}\text { EDXS } \\
\text { F4 }\end{array}$ & $\begin{array}{c}\text { EDXS } \\
\text { F5 }\end{array}$ & $\begin{array}{c}\text { EDXS } \\
\text { F6 }\end{array}$ \\
\hline $\mathrm{Al}$ & 0 & 0 & 0 & 0 & 0 & 0 & 6700 & 0 \\
\hline $\mathrm{Si}$ & 41600 & 29900 & 27900 & 22200 & 25900 & 20200 & 23300 & 66100 \\
\hline $\mathrm{K}$ & 41600 & 32600 & 21400 & 77600 & 35900 & 41300 & 41200 & 52000 \\
\hline $\mathrm{Ca}$ & 1100 & 4000 & 1800 & 600 & 0 & 0 & 1900 & 2300 \\
\hline $\mathrm{Cr}$ & 3100 & 4300 & 0 & 0 & 0 & 0 & 0 & 0 \\
\hline $\mathrm{Fe}$ & 59300 & 33100 & 298000 & 13000 & 14200 & 618400 & 36000 & 23200 \\
\hline $\mathrm{Zn}$ & 173000 & 173500 & 205900 & 146400 & 143100 & 175200 & 126700 & 163600 \\
\hline $\mathrm{Zr}$ & 755 & 978 & 0 & 7000 & 1700 & 3100 & 6300 & 0 \\
\hline $\mathrm{Cd}$ & 216000 & 222900 & 203500 & 246700 & 241600 & 241600 & 244000 & 175500 \\
\hline $\mathrm{Cs}$ & 17300 & 23300 & 29600 & 73300 & 81900 & 58300 & 82400 & 60600 \\
\hline $\mathrm{Pb}$ & 199100 & 215100 & 216000 & 230400 & 229100 & 196200 & 237200 & 140900 \\
\hline
\end{tabular}


Filter Particulate Analysis - ARM090894

\begin{tabular}{|c|c|l|c|c|l|l|l|}
\hline Element & $\begin{array}{c}\text { XRF } \\
4.1\end{array}$ & $\begin{array}{c}\text { XRF } \\
5.1\end{array}$ & $\begin{array}{c}\text { EDXS } \\
\text { F1 }\end{array}$ & $\begin{array}{c}\text { EDXS } \\
\text { F2 }\end{array}$ & $\begin{array}{c}\text { EDXS } \\
\text { F3 }\end{array}$ & $\begin{array}{c}\text { EDXS } \\
\text { F4 }\end{array}$ & $\begin{array}{c}\text { EDXS } \\
\text { F5 }\end{array}$ \\
\hline $\mathrm{Al}$ & 0 & 0 & 0 & 0 & 0 & 0 & 6700 \\
\hline $\mathrm{Si}$ & 27800 & 55800 & 51100 & 48600 & 85900 & 105900 & 54200 \\
\hline $\mathrm{K}$ & 13200 & 7900 & 39000 & 40400 & 55500 & 60700 & 54200 \\
\hline $\mathrm{Ca}$ & 1100 & 2200 & 600 & 4900 & 1000 & 4300 & 2900 \\
\hline $\mathrm{Cr}$ & 0 & 0 & 900 & 5000 & 1400 & 1000 & 900 \\
\hline $\mathrm{Fe}$ & 35900 & 19800 & 38300 & 67200 & 40000 & 27600 & 28200 \\
\hline $\mathrm{Zn}$ & 190100 & 200600 & 212700 & 145300 & 211600 & 123400 & 230300 \\
\hline $\mathrm{Zr}$ & 656 & 1100 & 0 & 0 & 0 & 0 & 0 \\
\hline $\mathrm{Cd}$ & 218200 & 61800 & 220000 & 289500 & 187600 & 57800 & 50800 \\
\hline $\mathrm{Cs}$ & 14700 & 22600 & 34200 & 33100 & 72700 & 81000 & 112000 \\
\hline $\mathrm{Pb}$ & 178700 & 145200 & 196100 & 124000 & 108000 & 86400 & 132500 \\
\hline
\end{tabular}


Filter Particulate Analysis - ARM092094.

\begin{tabular}{|c|c|c|}
\hline Element & EDXS-F1 & EDXS-F2 \\
\hline $\mathrm{Al}$ & 0 & 0 \\
\hline $\mathrm{Si}$ & 36900 & 24700 \\
\hline $\mathrm{K}$ & 17700 & 31500 \\
\hline $\mathrm{Ca}$ & 0 & 900 \\
\hline $\mathrm{Cr}$ & 800 & 3400 \\
\hline $\mathrm{Fe}$ & 16100 & 12500 \\
\hline $\mathrm{Zn}$ & 238800 & 195500 \\
\hline $\mathrm{Zr}$ & 0 & 0 \\
\hline $\mathrm{Cd}$ & 157800 & 199700 \\
\hline $\mathrm{Cs}$ & 12100 & 27000 \\
\hline $\mathrm{Pb}$ & 277300 & 254700 \\
\hline
\end{tabular}


Filter Particulate Analysis - ARM092294.

\begin{tabular}{|c|c|c|c|c|}
\hline Element & EDXS-F1 & EDXS-F3 & EDXS-F4 & EDXS-F5 \\
\hline $\mathrm{Al}$ & 0 & 1000 & 0 & 900 \\
\hline $\mathrm{Si}$ & 3200 & 28900 & 34700 & 68300 \\
\hline $\mathrm{K}$ & 23600 & 30700 & 37800 & 32300 \\
\hline $\mathrm{Ca}$ & 0 & 2400 & 1300 & 2000 \\
\hline $\mathrm{Cr}$ & 0 & 0 & 5200 & 2600 \\
\hline $\mathrm{Fe}$ & 5000 & 12500 & 21500 & 29600 \\
\hline $\mathrm{Zn}$ & 292400 & 242900 & 165100 & 250900 \\
\hline $\mathrm{Zr}$ & 0 & 0 & 0 & 0 \\
\hline $\mathrm{Cd}$ & 208700 & 231000 & 281700 & 164300 \\
\hline $\mathrm{Cs}$ & 19700 & 13800 & 21800 & 17200 \\
\hline $\mathrm{Pb}$ & 244500 & 199800 & 196500 & 220000 \\
\hline
\end{tabular}


Melter Chamber Condensate/Particulate Analysis.

\begin{tabular}{|c|c|c|c|c|}
\hline Element & ARM082394 & ARM082694 & ARM090694 & ARM090894 \\
\hline $\mathrm{Na}$ & 0 & 0 & 0 & 0 \\
\hline $\mathrm{Mg}$ & 0 & 0 & 0 & 0 \\
\hline $\mathrm{Al}$ & 0 & 0 & 0 & 0 \\
\hline $\mathrm{Si}$ & 26800 & 13000 & 7300 & 10900 \\
\hline $\mathrm{K}$ & 16200 & 21000 & 18800 & 14900 \\
\hline $\mathrm{Ca}$ & 26900 & 17000 & 20000 & 20100 \\
\hline $\mathrm{Ti}$ & 23800 & 15000 & 25900 & 24500 \\
\hline $\mathrm{Fe}$ & 146200 & 72600 & 125200 & 141300 \\
\hline $\mathrm{Zn}$ & 155600 & 175600 & 190000 & 161700 \\
\hline $\mathrm{Zr}$ & 27200 & 12300 & 22000 & 26700 \\
\hline $\mathrm{Cd}$ & 313000 & 358400 & 378300 & 166200 \\
\hline $\mathrm{Cs}$ & 18000 & 15600 & 31100 & 12100 \\
\hline $\mathrm{Ce}$ & 7600 & 4600 & 5900 & 3000 \\
\hline $\mathrm{Sm}$ & 9900 & 6700 & -9200 & 13500 \\
\hline $\mathrm{Pb}$ & 230400 & 199500 & 219900 & 161700 \\
\hline
\end{tabular}


ARM082394 Slag Analysis.

\begin{tabular}{|c|c|c|c|c|}
\hline Element & TOP-XRF & TOP-EDXS & BOT-XRF & BOT-EDXS \\
\hline $\mathrm{Na}$ & 0 & 9900 & 0 & 9600 \\
\hline $\mathrm{Mg}$ & 26400 & 10300 & 34300 & 10000 \\
\hline $\mathrm{Al}$ & 81200 & 50900 & 74000 & 51400 \\
\hline $\mathrm{Si}$ & 246000 & 193700 & 276000 & 195000 \\
\hline $\mathrm{K}$ & 19400 & 10700 & 25400 & 11100 \\
\hline $\mathrm{Ca}$ & 38300 & 29900 & 36300 & 30600 \\
\hline $\mathrm{Ti}$ & 24300 & 23900 & 30600 & 24000 \\
\hline $\mathrm{Cr}$ & 0 & 3200 & 0 & 3200 \\
\hline $\mathrm{Fe}$ & 152000 & 127000 & 126400 & 121000 \\
\hline $\mathrm{Zn}$ & 1600 & 0 & 1100 & 0 \\
\hline $\mathrm{Zr}$ & 15800 & 35500 & 15800 & 32900 \\
\hline $\mathrm{Cd}$ & 8 & 0 & 0 & 0 \\
\hline $\mathrm{Ce}$ & 483 & 2100 & 728 & 3400 \\
\hline $\mathrm{Cs}$ & 557 & 2100 & 8800 & 2400 \\
\hline $\mathrm{Sm}$ & 1900 & 1600 & 6900 & 0 \\
\hline $\mathrm{Pb}$ & 2400 & 0 & 2500 & 0 \\
\hline
\end{tabular}


ARM-082694 Slag Analysis.

\begin{tabular}{|c|c|c|c|c|}
\hline Element & TOP-XRF & TOP-EDXS & BOT-XRF & BOT-EDXS \\
\hline $\mathrm{Na}$ & 0 & 12300 & 0 & 10600 \\
\hline $\mathrm{Mg}$ & 28000 & 13100 & 27400 & 12300 \\
\hline $\mathrm{Al}$ & 65100 & 49700 & 57600 & 47600 \\
\hline $\mathrm{Si}$ & 246300 & 210800 & 218600 & 201600 \\
\hline $\mathrm{K}$ & 22100 & 12200 & 21200 & 11300 \\
\hline $\mathrm{Ca}$ & 37300 & 40200 & 38100 & 38800 \\
\hline $\mathrm{Ti}$ & 29100 & 26300 & 29400 & 25300 \\
\hline $\mathrm{Cr}$ & 0 & 3900 & 0 & 3700 \\
\hline $\mathrm{Fe}$ & 118000 & 120800 & 129400 & 123500 \\
\hline $\mathrm{Zn}$ & 2300 & 0 & 2100 & 0 \\
\hline $\mathrm{Zr}$ & 15400 & 101500 & 17000 & 108200 \\
\hline $\mathrm{Cd}$ & 215 & 0 & 79 & 0 \\
\hline $\mathrm{Ce}$ & 1600 & 4900 & 863 & 3200 \\
\hline $\mathrm{Cs}$ & 2300 & 3000 & 1100 & 3000 \\
\hline $\mathrm{Sm}$ & 7100 & 3700 & 7300 & 2400 \\
\hline $\mathrm{Pb}$ & 7000 & 0 & 6100 & 0 \\
\hline & & & & \\
\hline & & & & \\
\hline
\end{tabular}


ARM-090694 Slag Analysis.

\begin{tabular}{|c|c|c|c|c|}
\hline Element & TOP-XRF & TOP-EDXS & BOT-XRF & BOT-EDXS \\
\hline $\mathrm{Na}$ & 0 & 13200 & 0 & 15200 \\
\hline $\mathrm{Mg}$ & 32800 & 13000 & 48600 & 14600 \\
\hline $\mathrm{Al}$ & 57600 & 43900 & 48000 & 45400 \\
\hline $\mathrm{Si}$ & 57600 & 43900 & 222300 & 200000 \\
\hline $\mathrm{K}$ & 22800 & 11200 & 14800 & 11900 \\
\hline $\mathrm{Ca}$ & 45500 & 42600 & 37000 & 42400 \\
\hline $\mathrm{Ti}$ & 34600 & 27000 & 24700 & 27100 \\
\hline $\mathrm{Cr}$ & 0 & 2200 & 0 & 3100 \\
\hline $\mathrm{Fe}$ & 150000 & 147400 & 126900 & 151800 \\
\hline $\mathrm{Zn}$ & 2100 & 0 & 1700 & 0 \\
\hline $\mathrm{Zr}$ & 14400 & 73100 & 13600 & 62900 \\
\hline $\mathrm{Cd}$ & 45 & 0 & 32 & 0 \\
\hline $\mathrm{Ce}$ & 1400 & 4300 & 1300 & 2400 \\
\hline $\mathrm{Cs}$ & 1400 & 2100 & 1300 & 2300 \\
\hline $\mathrm{Sm}$ & 6800 & 0 & 5300 & 1900 \\
\hline $\mathrm{Pb}$ & 2500 & 0 & 2000 & 0 \\
\hline
\end{tabular}


ARM-090894 Slag Analysis.

\begin{tabular}{|c|c|c|c|c|}
\hline Element & TOP-XRF & TOP-EDXS & BOT-XRF & BOT-EDXS \\
\hline $\mathrm{Na}$ & 0 & 14400 & 0 & 13900 \\
\hline $\mathrm{Mg}$ & 26600 & 14900 & 34500 & 14800 \\
\hline $\mathrm{Al}$ & 57200 & 47800 & 61000 & 47300 \\
\hline $\mathrm{Si}$ & 265700 & 202300 & 263900 & 199300 \\
\hline $\mathrm{K}$ & 20900 & 12700 & 23900 & 12200 \\
\hline $\mathrm{Ca}$ & 41600 & 43400 & 45200 & 42900 \\
\hline $\mathrm{Ti}$ & 30900 & 27500 & 34600 & 27800 \\
\hline $\mathrm{Cr}$ & 0 & 3200 & 0 & 2100 \\
\hline $\mathrm{Fe}$ & 128700 & 131600 & 143000 & 133200 \\
\hline $\mathrm{Zn}$ & 1800 & 0 & 2000 & 0 \\
\hline $\mathrm{Zr}$ & 16100 & 82300 & 17400 & 81800 \\
\hline $\mathrm{Cd}$ & 19 & 0 & 20 & 0 \\
\hline $\mathrm{Ce}$ & 1400 & 4700 & 1300 & 2300 \\
\hline $\mathrm{Cs}$ & 1700 & 3400 & 1700 & 3100 \\
\hline $\mathrm{Sm}$ & 6800 & 2900 & 7600 & 0 \\
\hline $\mathrm{Pb}$ & 2700 & 0 & 2900 & 0 \\
\hline
\end{tabular}


ARM-092094 Slag Analysis.

\begin{tabular}{|c|c|c|}
\hline Element & TOP-EDXS & BOT-EDXS \\
\hline $\mathrm{Na}$ & 11700 & 13600 \\
\hline $\mathrm{Mg}$ & 14900 & 15300 \\
\hline $\mathrm{Al}$ & 46200 & 48200 \\
\hline $\mathrm{Si}$ & 194100 & 201100 \\
\hline $\mathrm{K}$ & 11000 & 9900 \\
\hline $\mathrm{Ca}$ & 46500 & 46600 \\
\hline $\mathrm{Ti}$ & 25700 & 25900 \\
\hline $\mathrm{Cr}$ & 1900 & 2200 \\
\hline $\mathrm{Fe}$ & 124800 & 123300 \\
\hline $\mathrm{Zn}$ & 0 & 0 \\
\hline $\mathrm{Zr}$ & 84500 & 89000 \\
\hline $\mathrm{Cd}$ & 0 & 0 \\
\hline $\mathrm{Ce}$ & 2600 & 4400 \\
\hline $\mathrm{Cs}$ & 2700 & 2200 \\
\hline $\mathrm{Sm}$ & 1500 & 1800 \\
\hline $\mathrm{Pb}$ & 0 & 0 \\
\hline
\end{tabular}


ARM-092294 Slag Analysis.

\begin{tabular}{|c|c|c|}
\hline Element & TOP-EDXS & BOT-EDXS \\
\hline $\mathrm{Na}$ & 10300 & 13900 \\
\hline $\mathrm{Mg}$ & 15100 & 15400 \\
\hline $\mathrm{Al}$ & 49500 & 37500 \\
\hline $\mathrm{Si}$ & 212500 & 138000 \\
\hline $\mathrm{K}$ & 13000 & 4700 \\
\hline $\mathrm{Ca}$ & 50500 & 19000 \\
\hline $\mathrm{Ti}$ & 28200 & 8000 \\
\hline $\mathrm{Cr}$ & 3700 & 40910 \\
\hline $\mathrm{Fe}$ & 109200 & 37500 \\
\hline $\mathrm{Zn}$ & 0 & 0 \\
\hline $\mathrm{Zr}$ & 88300 & 14600 \\
\hline $\mathrm{Cd}$ & 0 & 0 \\
\hline $\mathrm{Ce}$ & 3000 & 1000 \\
\hline $\mathrm{Cs}$ & 3400 & 500 \\
\hline $\mathrm{Sm}$ & 4100 & 4800 \\
\hline $\mathrm{Pb}$ & 0 & 0 \\
\hline & & \\
\hline & & \\
\hline
\end{tabular}




\section{Appendix F}

\section{ICP and FLAA Data}




\begin{tabular}{|c|c|c|c|c|c|c|}
\hline \multicolumn{7}{|c|}{ Lockheed Martin Idaho Technologies } \\
\hline & & & & & & \\
\hline \multicolumn{7}{|c|}{ Experiment Name - ARM082394 } \\
\hline \multicolumn{7}{|c|}{ Date conducted - Aug 23, 1994} \\
\hline & & & & & & \\
\hline \multicolumn{7}{|c|}{ Analysis - Triangle Labs } \\
\hline \multicolumn{7}{|c|}{\begin{tabular}{|l|} 
Project \# - 33627A \\
\end{tabular}} \\
\hline \multicolumn{7}{|c|}{ Filter Samples } \\
\hline & & & & & & \\
\hline & & & & & & \\
\hline & A0823F12 & A0823F12 L & A0823F22 & A0823F22 & A0823F32 & A0823F42 \\
\hline \multirow[t]{2}{*}{ analyte } & total ug & total ug & total ug & total ug & total ug & total ug \\
\hline & & & & & & \\
\hline $\mathrm{Al}$ & 4250 & 10000 & 4000 & 4420 & 3990 & 3240 \\
\hline $\mathrm{Ca}$ & 6260 & 7160 & 5020 & 5150 & 6160 & 5710 \\
\hline $\mathrm{Cd}$ & 194400 & 200000 & 81200 & 82400 & 78200 & 75500 \\
\hline $\mathrm{Ce}$ & 772 & 828 & 171 & 938 & 523 & 378 \\
\hline $\mathrm{Cr}$ & 1370 & 1410 & 1010 & 1110 & 2230 & 2480 \\
\hline Cs & 25000 & 25000 & 22600 & 22600 & 37600 & 20400 \\
\hline $\mathrm{Fe}$ & 50000 & 51700 & 29400 & 29500 & 44700 & 27200 \\
\hline $\bar{K}$ & 15300 & 26700 & 14500 & 14200 & 29200 & 17000 \\
\hline $\mathrm{Mg}$ & 2550 & 3140 & 2610 & 2760 & 2900 & 2040 \\
\hline $\mathrm{Na}$ & 32100 & 40400 & 24900 & 25100 & 5.1500 & 35500 \\
\hline $\mathrm{Ni}$ & 67 & 74 & 44 & 45 & 112 & 87 \\
\hline$P$ & 3780 & 4280 & 3730 & 3780 & 8280 & 6150 \\
\hline $\mathrm{Pb}$ & 237500 & 242900 & 93300 & 94500 & 161300 & 141300 \\
\hline Si & 1030700 & 1356000 & 804700 & 821700 & 1107900 & 995700 \\
\hline $\mathrm{Ti}$ & 1740 & 1860 & 2210 & 2250 & 2860 & 3070 \\
\hline $\mathrm{Zn}$ & 124700 & 127900 & 64500 & 65400 & 82200 & 98100 \\
\hline $\mathrm{Sm}$ & 140 & 200 & 366 & 381 & 171 & 40 \\
\hline & & & & & & \\
\hline \multicolumn{2}{|c|}{ Total mass (ug) } & 2099552 & 1154261 & 1176234 & 1619826 & 1433895 \\
\hline & & & & & & \\
\hline & & & & & & \\
\hline & & & & & & \\
\hline
\end{tabular}




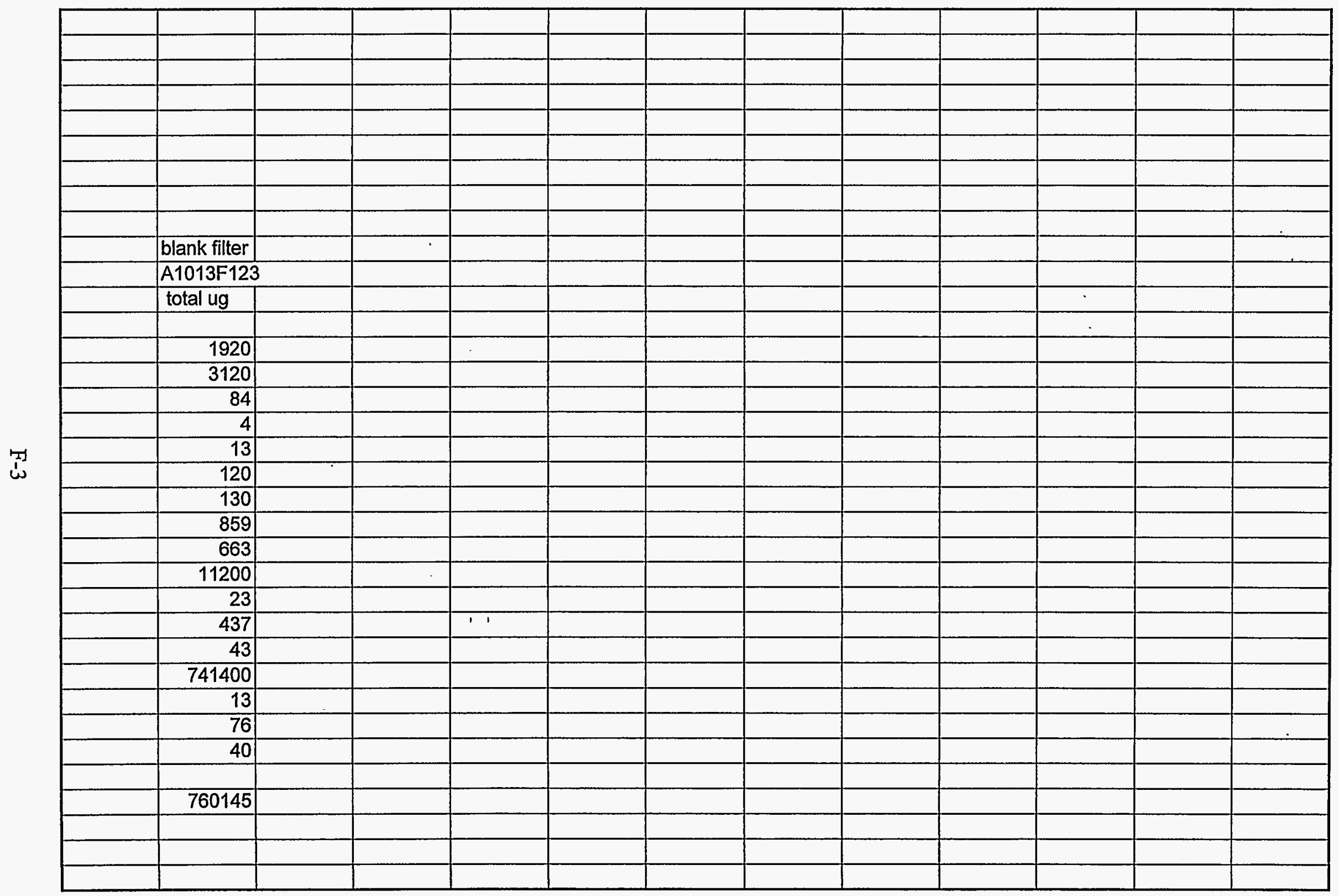




\begin{tabular}{|c|c|c|c|c|c|c|}
\hline \multicolumn{7}{|c|}{ Minus Blank Filter Constituents } \\
\hline & \multirow{3}{*}{\begin{tabular}{|l|} 
A0823F12 \\
total ug \\
\end{tabular}} & & \multirow{3}{*}{\begin{tabular}{|l|} 
A0823F22 \\
total ug \\
\end{tabular}} & & \multirow{3}{*}{\begin{tabular}{|l|} 
A0823F32 \\
total ug \\
\end{tabular}} & \\
\hline \multirow[b]{2}{*}{ analyte } & & $\mathrm{A} 0823 \mathrm{~F} 12 \mathrm{~L}$ & & A0823F22 D/ & & \multirow{2}{*}{\begin{tabular}{|l|} 
A0823F42 \\
total ug \\
\end{tabular}} \\
\hline & & total ug & & total ug & & \\
\hline & & & & & & \\
\hline $\mathrm{Al}$ & 2330 & 8080 & 2080 & 2500 & 2070 & 1320 \\
\hline $\mathrm{Ca}$ & 3140 & 4040 & 1900 & 2030 & 3040 & 2590 \\
\hline $\mathrm{Cd}$ & 194316 & 199916 & 81116 & 82316 & 78116 & 75416 \\
\hline $\mathrm{Ce}$ & 768 & 824 & 167 & 934 & 519 & 374 \\
\hline $\mathrm{Cr}$ & 1357 & 1397 & 997 & 1097 & 2217 & 2467 \\
\hline Cs & 24880 & 24880 & 22480 & 22480 & 37480 & 20280 \\
\hline $\mathrm{Fe}$ & 49870 & 51570 & 29270 & 29370 & 44570 & 27070 \\
\hline $\mathrm{K}$ & 14441 & 25841 & 13641 & 13341 & 28341 & 16141 \\
\hline $\mathrm{Mg}$ & 1887 & 2477 & 1947 & 2097 & 2237 & 1377 \\
\hline $\mathrm{Na}$ & 20900 & 29200 & 13700 & 13900 & 40300 & 24300 \\
\hline $\mathrm{Ni}$ & 44 & 51 & 21 & 22 & 89 & 64 \\
\hline$P$ & 3343 & 3843 & 3293 & 3343 & 7843 & 5713 \\
\hline $\mathrm{Pb}$ & 237457 & 242857 & 93257 & 94457 & 161257 & 141257 \\
\hline Si & 289300 & 614600 & 63300 & 80300 & 366500 & 254300 \\
\hline $\mathrm{Ti}$ & 1727 & 1847 & 2197 & 2237 & 2847 & 3057 \\
\hline$Z n$ & 124624 & 127824 & 64424 & 65324 & 82124 & 98024 \\
\hline $\mathrm{Sm}$ & 100 & 160 & 326 & 341 & 131 & 0 \\
\hline & & & & & & \\
\hline Total Mas & 970484 & 1339407 & 394116 & 416089 & 859681 & 673750 \\
\hline & & 11 & & & & \\
\hline & & & & & & \\
\hline & & & & & & \\
\hline & & & & & & \\
\hline & & & & & & \\
\hline & & & & & & \\
\hline & & & & & & \\
\hline & & & & & & \\
\hline & & & & & & \\
\hline & & & & & & \\
\hline
\end{tabular}




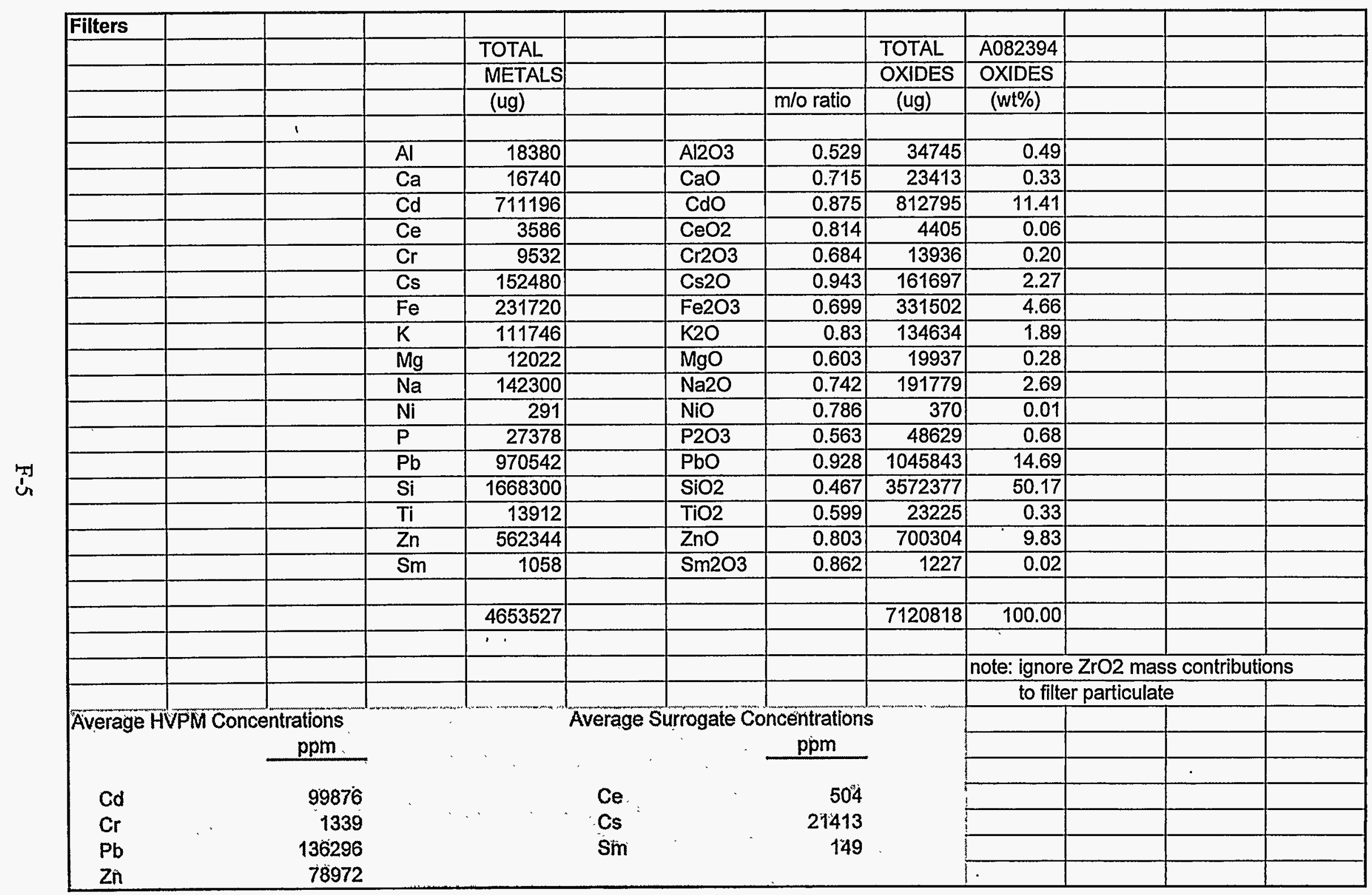




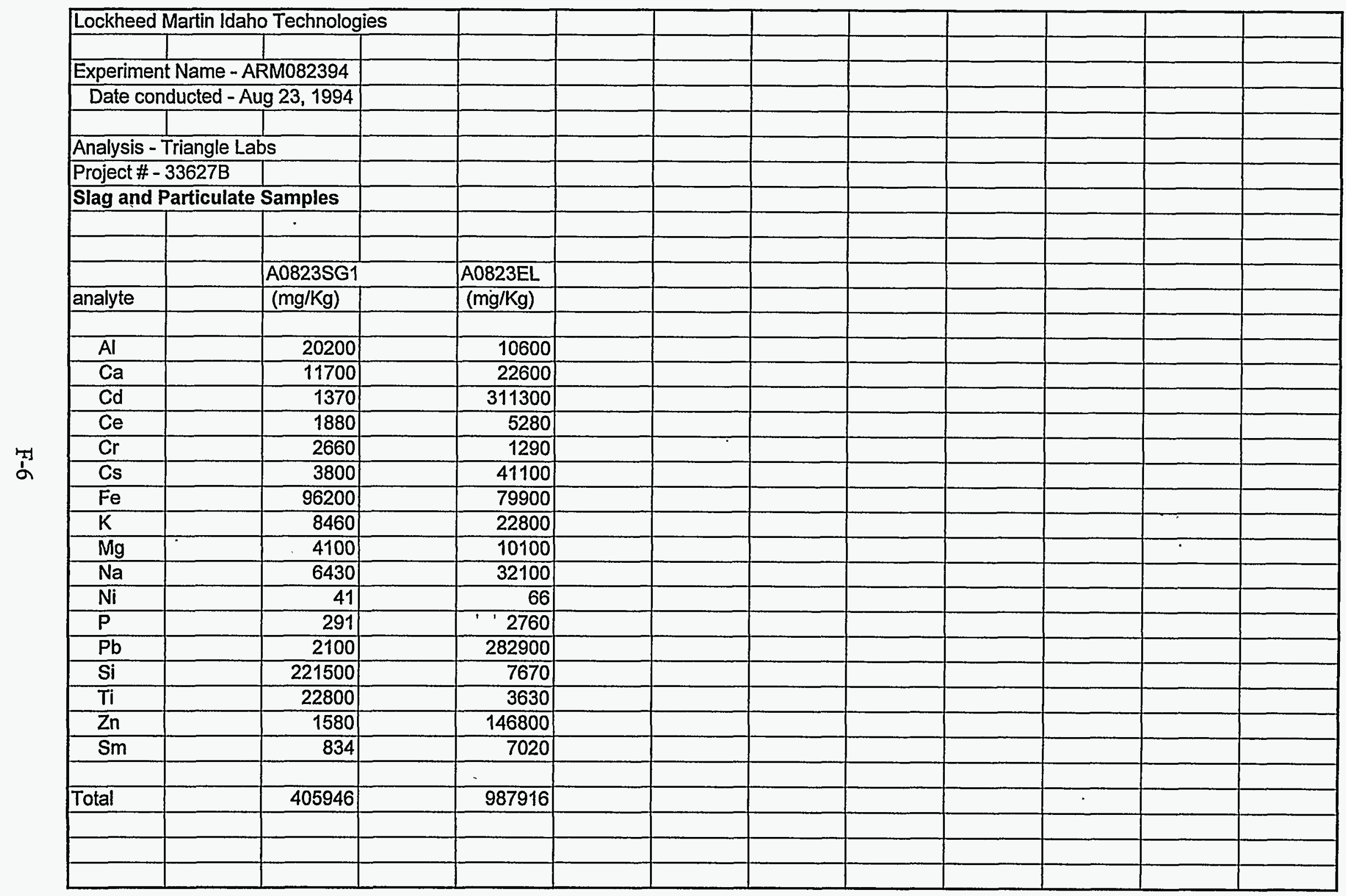




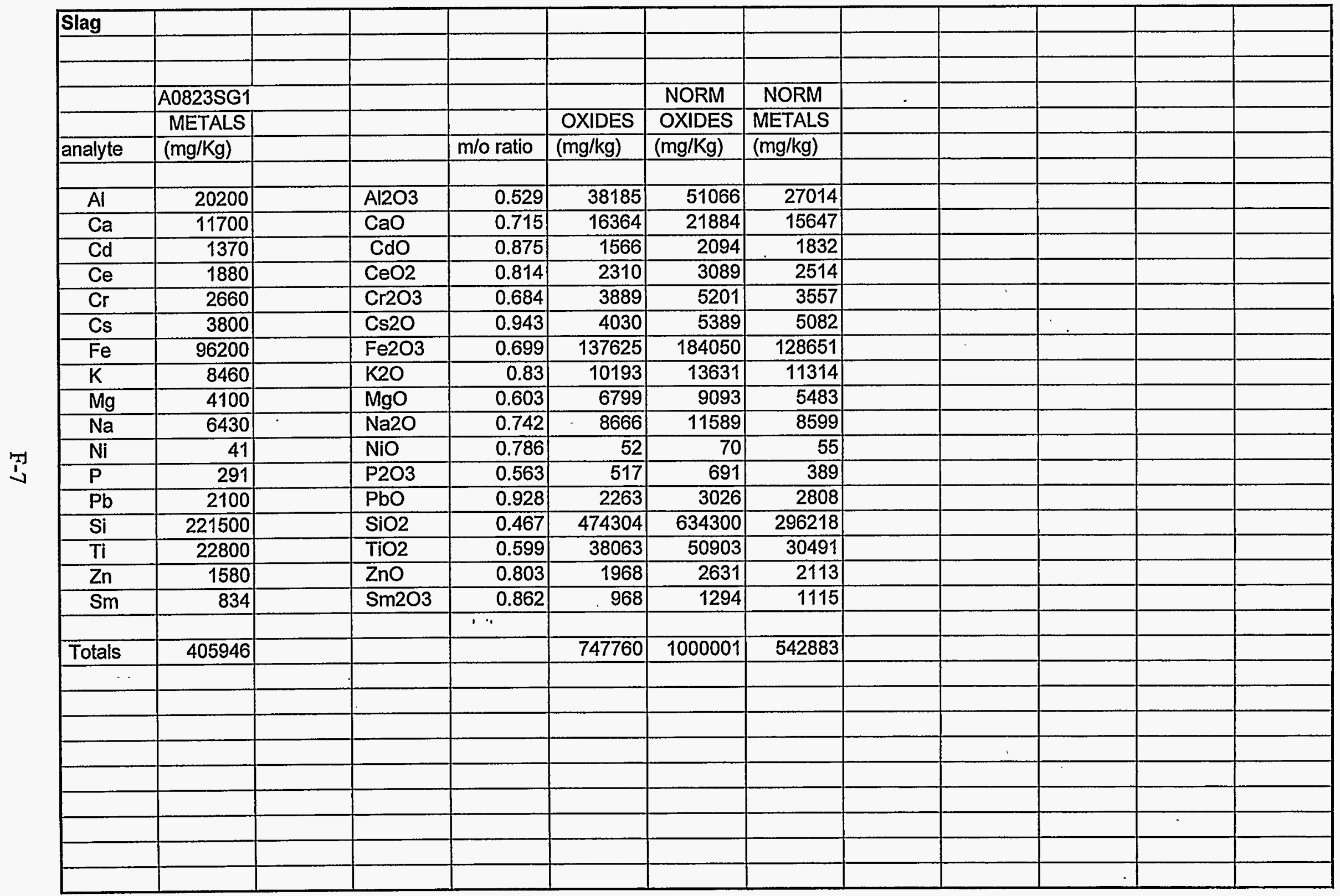




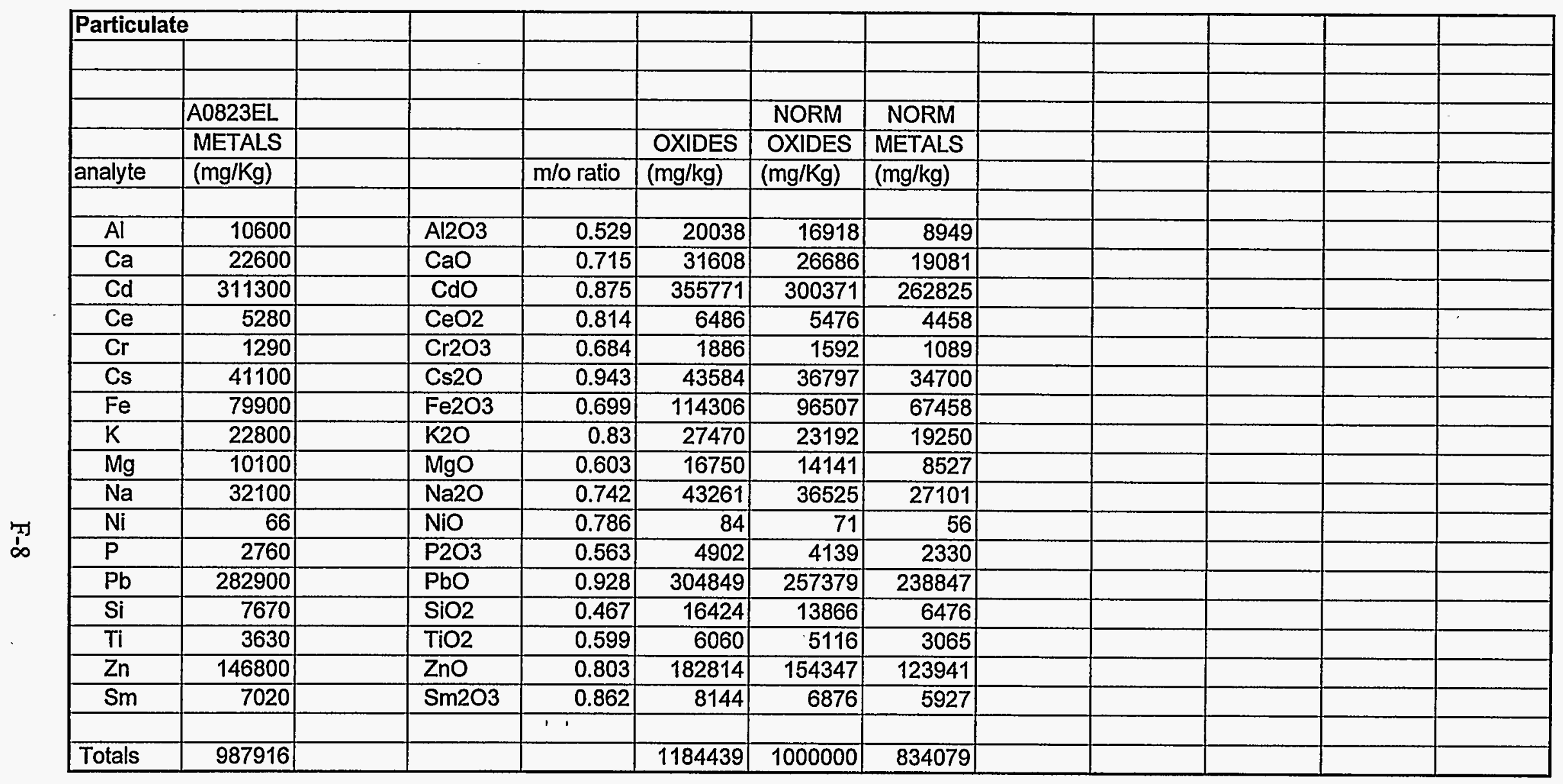




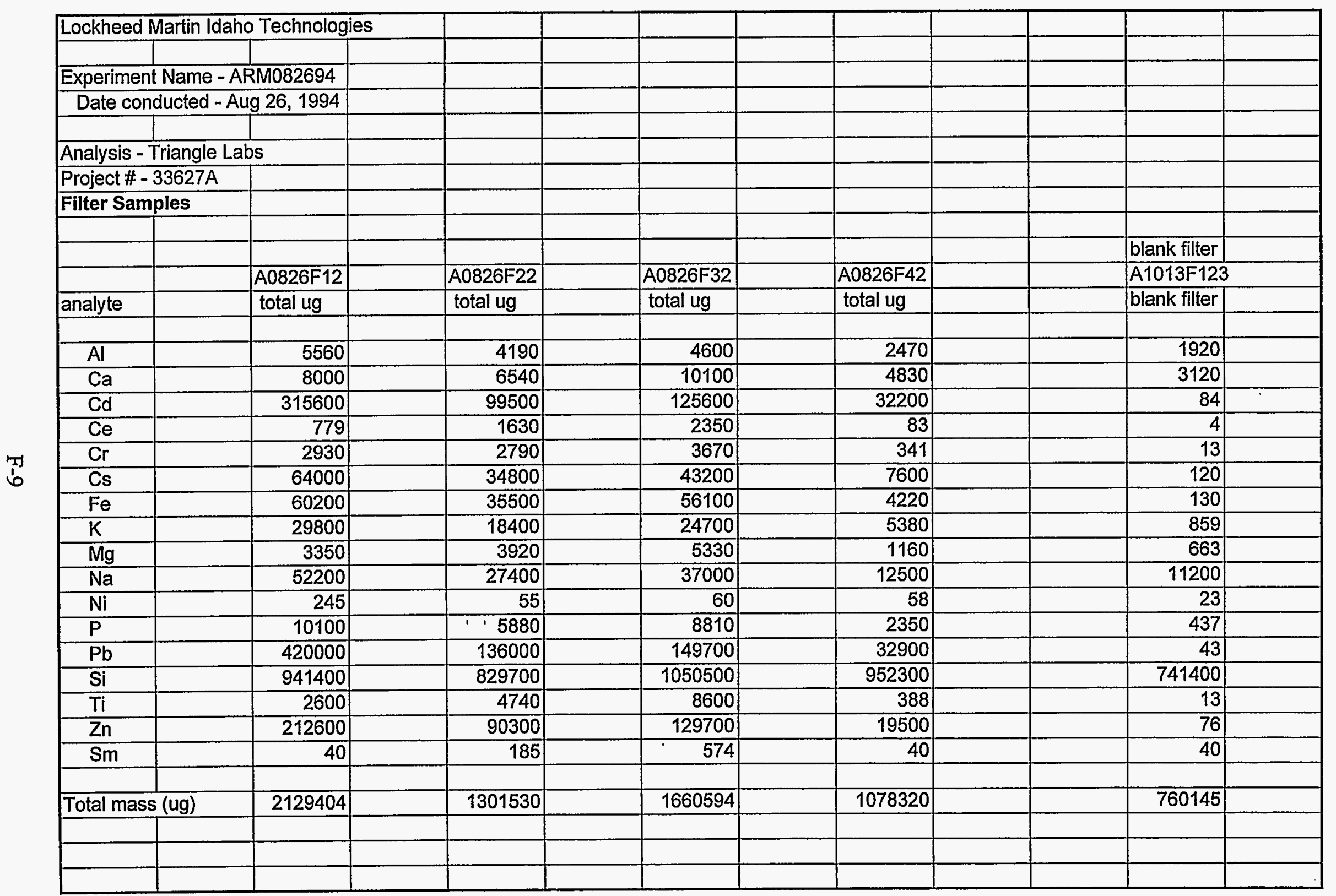




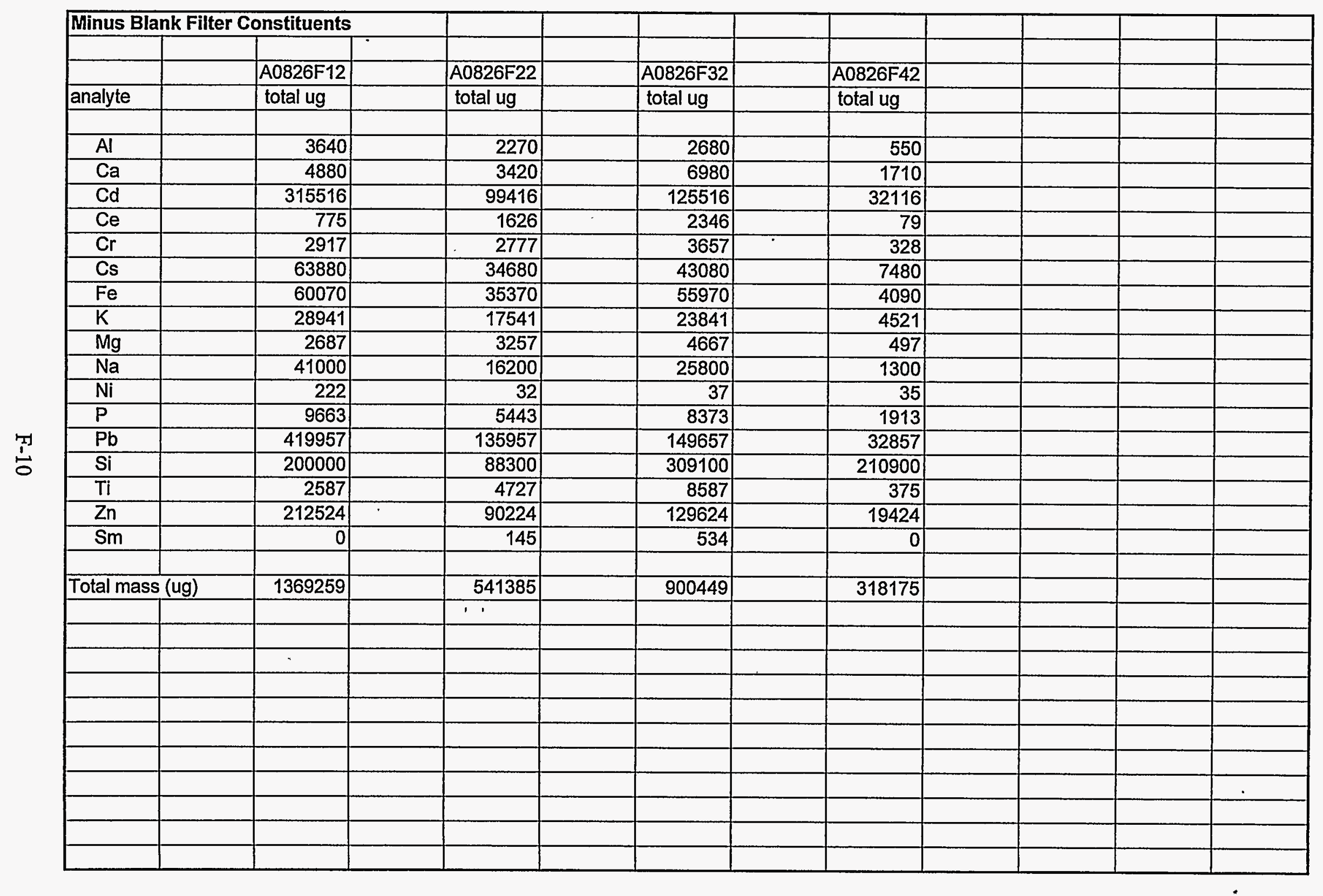




\begin{tabular}{|c|c|c|c|c|c|c|c|c|c|c|c|c|}
\hline Filters & & & & & & & & & & & & \\
\hline & TOTAL & & & & TOTAL & A082694 & & & & & & \\
\hline & METALS & & & & OXIDES & OXIDES & & & & & & \\
\hline analyte & (ug) & & & $\mathrm{m} / \mathrm{o}$ ratio & (ug) & $(w t \%)$ & & & & & & \\
\hline & & & & & & & & & & & & \\
\hline $\mathrm{Al}$ & 9140 & & Al2O3 & 0.529 & 17278 & 0.39 & & & & & & \\
\hline $\mathrm{Ca}$ & 16990 & & $\mathrm{CaO}$ & 0.715 & 23762 & 0.53 & & & & & & \\
\hline Cd & 572564 & & $\mathrm{CdO}$ & 0.875 & 654359 & 14.60 & & & & & & \\
\hline $\mathrm{Ce}$ & 4826 & & $\mathrm{CeO} 2$ & 0.814 & 5929 & 0.13 & & & & & & \\
\hline $\mathrm{Cr}$ & 9679 & & $\mathrm{Cr} 2 \mathrm{O} 3$ & 0.684 & 14151 & 0.32 & & & & & & \\
\hline Cs & 149120 & & $\mathrm{Cs} 2 \mathrm{O}$ & 0.943 & 158134 & 3.53 & & & & & & \\
\hline$\overline{\mathrm{Fe}}$ & 155500 & & $\mathrm{Fe} 2 \mathrm{O} 3$ & 0.699 & 222461 & 4.96 & & & & & & \\
\hline $\mathrm{K}$ & 74844 & & $\mathrm{~K} 2 \mathrm{O}$ & 0.83 & 90173 & 2.01 & & & & & & \\
\hline $\mathrm{Mg}$ & 11108 & & MgO & 0.603 & 18421 & 0.41 & & & & & & \\
\hline $\mathrm{Na}$ & 84300 & & $\mathrm{Na2O}$ & 0.742 & 113612 & 2.54 & & & & & & \\
\hline $\mathrm{Ni}$ & 326 & & $\mathrm{NiO}$ & 0.786 & 415 & 0.01 & & & & & & \\
\hline$P$ & 25392 & & P2O3 & 0.563 & 45101 & 1.01 & & & & & & \\
\hline $\mathrm{Pb}$ & 738428 & & $\mathrm{PbO}$ & 0.928 & 795720 & 17.76 & & & & & & \\
\hline Si & 808300 & & $\mathrm{SiO} 2$ & 0.467 & 1730835 & 38.63 & & & & & & \\
\hline$\overline{\mathrm{Ti}}$ & 16276 & & TiO2 & 0.599 & 27172 & 0.61 & & & & & & \\
\hline $\mathrm{Zn}$ & 451796 & & $\mathrm{ZnO}$ & 0.803 & 562635 & 12.56 & & & & & & \\
\hline $\mathrm{Sm}$ & 679 & & $\mathrm{Sm} 2 \mathrm{O3}$ & 0.862 & 788 & 0.02 & & & & & & \\
\hline & & & & & & & & & & & & \\
\hline & 3129268 & & & & 4480945 & 100.00 & & & & & & \\
\hline & & & & 1. & & 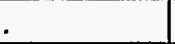 & & & & & & \\
\hline & & & & & & & & & note: ignore & $\mathrm{e} \mathrm{ZrO} 2 \mathrm{mas}$ & s contributi & \\
\hline & & & & & & & & & to filte & er particulat & & \\
\hline Average & PM Conice & ations & & & Average Si & Irrogate Co & entration & & & & & \\
\hline & & $\mathrm{ppm}$ & & & . & & $\mathrm{ppm}$ & . & & & & \\
\hline $\mathrm{Cd}$ & & 127778 & & & $\mathrm{Ce}$ & 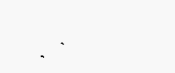 & 1077 & & & & & \\
\hline $\mathrm{Cr}$ & & 2160 & & & Cs & & 33279 & & & & & \\
\hline $\mathrm{Pb}$ & & 164793 & & . & sm & & 123 & & & & & \\
\hline $\mathrm{Zn}$ & & 100826 & & & & & & & & & & \\
\hline & & & & & & & & & & & & \\
\hline
\end{tabular}




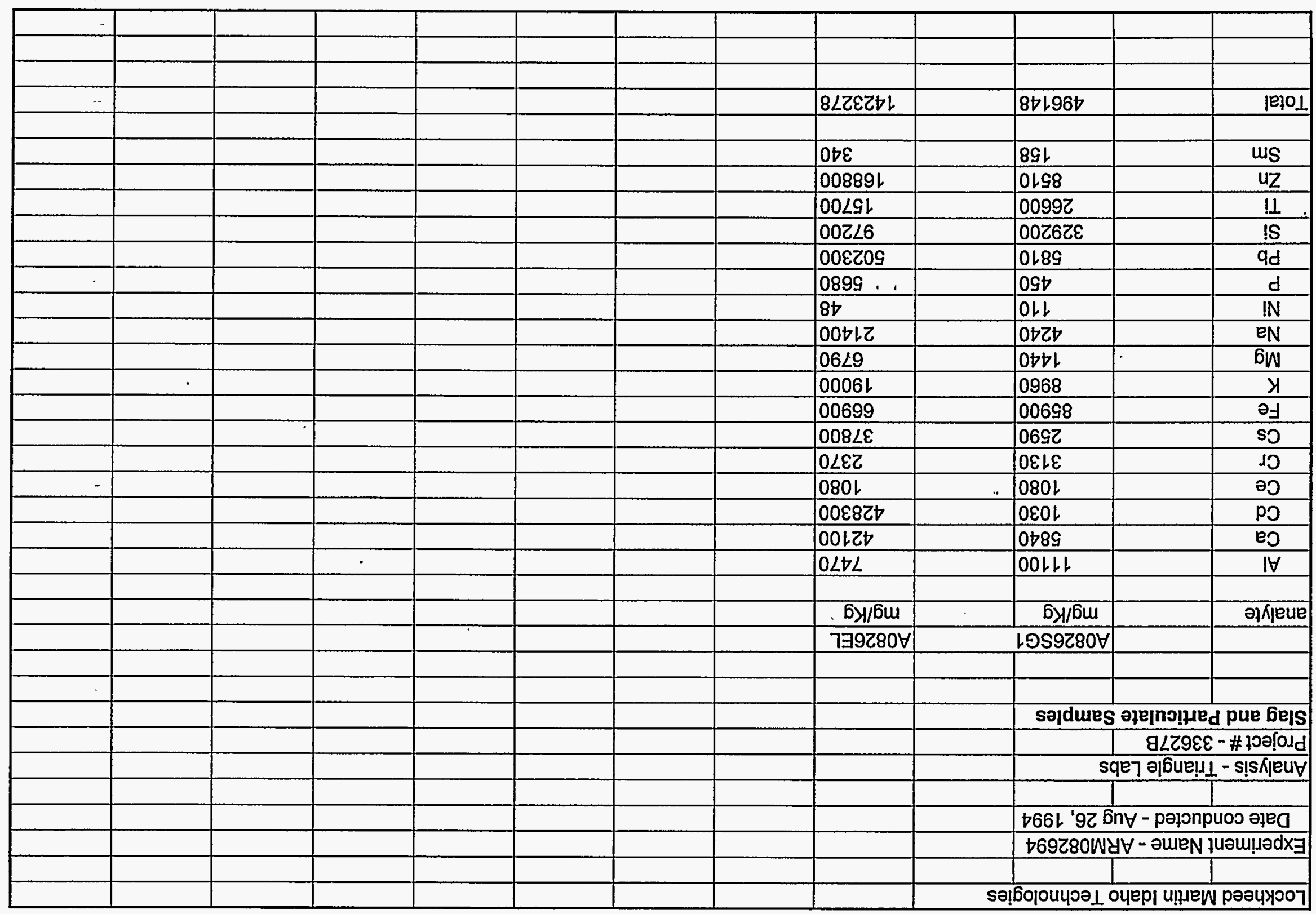




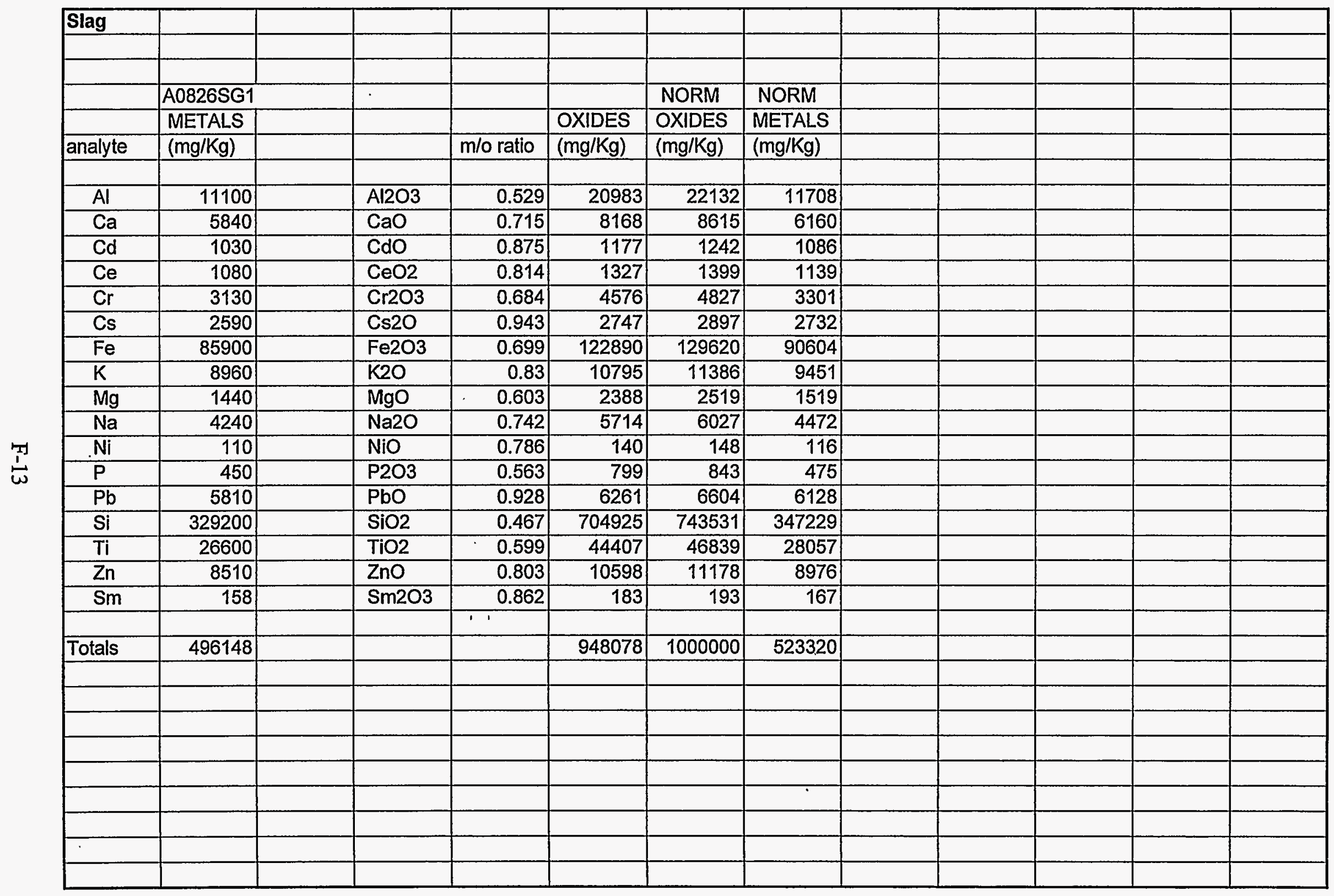




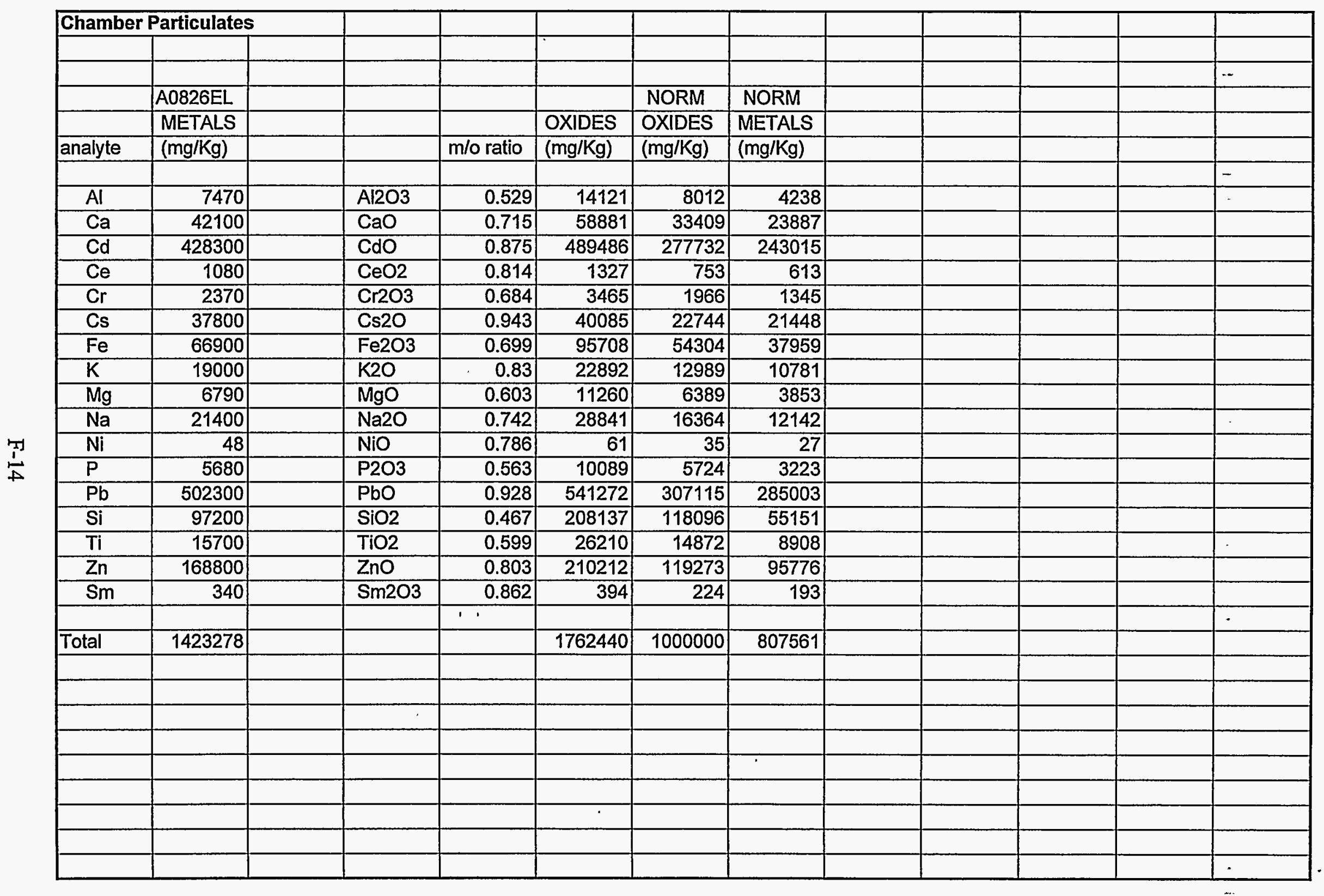




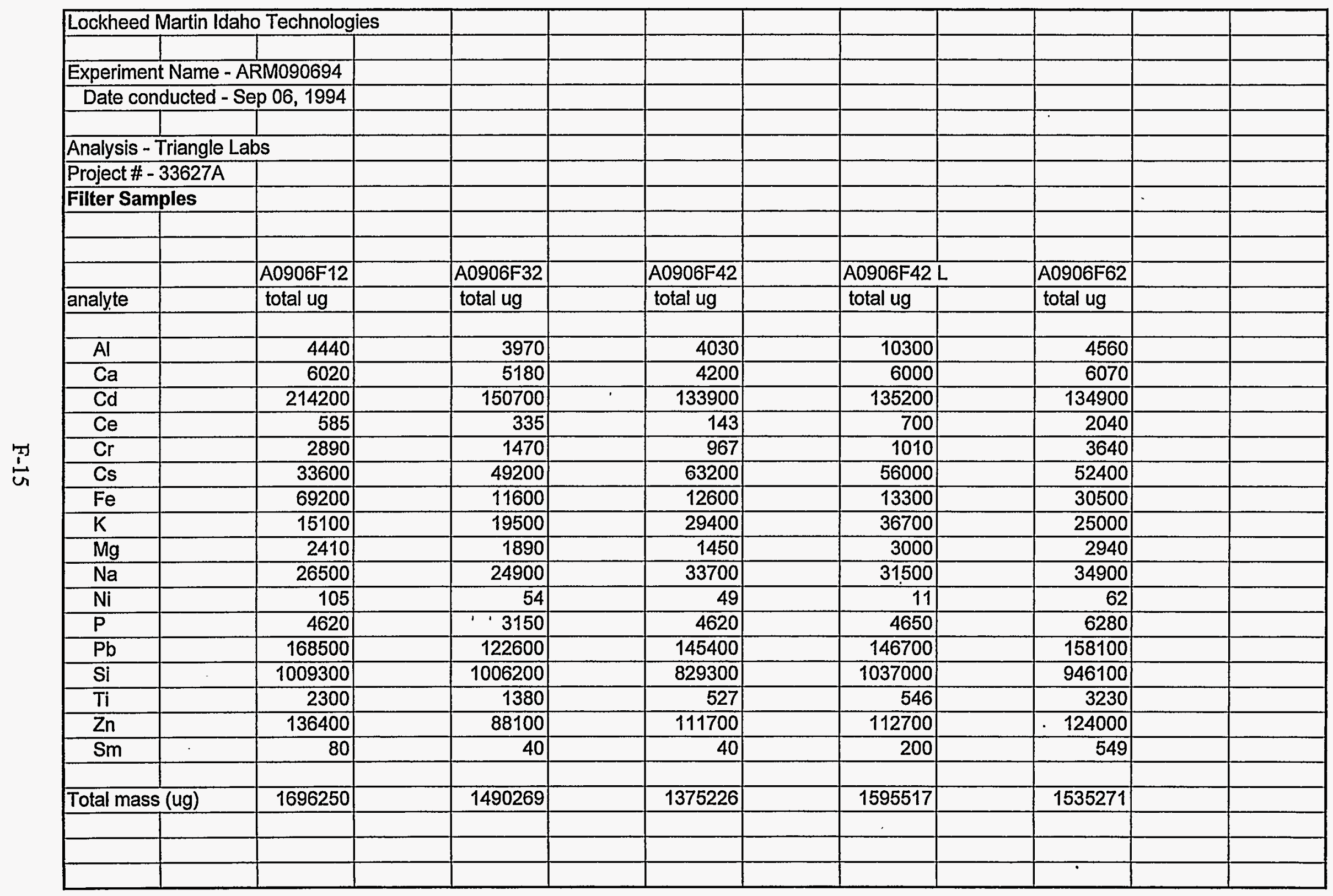




\begin{tabular}{|c|c|c|c|c|c|c|}
\hline \multicolumn{7}{|c|}{ Minus Blank Filter Constifuents } \\
\hline & & & & & \multirow{3}{*}{\begin{tabular}{|l|} 
A0906F62 \\
total ug \\
\end{tabular}} & \\
\hline & A0906F12 & A0906F32 & A0906F42 & A0906F42 L & & \multirow[t]{2}{*}{ - } \\
\hline analyte & total ug & total ug & total ug & total ug & & \\
\hline & & & & & & \\
\hline $\mathrm{Al}$ & 2520 & 2050 & 2110 & 8380 & 2640 & \\
\hline $\mathrm{Ca}$ & 2900 & 2060 & 1080 & 2880 & 2950 & - \\
\hline $\mathrm{Cd}$ & 214116 & 150616 & 133816 & 135116 & 134816 &.- \\
\hline $\mathrm{Ce}$ & 581 & 331 & 139 & 696 & 2036 & . \\
\hline $\mathrm{Cr}$ & 2877 & 1457 & 954 & 997 & 3627 & \\
\hline Cs & 33480 & 49080 & 63080 & 55880 & 52280 & \\
\hline $\mathrm{Fe}$ & 69070 & 11470 & 12470 & 13170 & 30370 & \\
\hline $\mathrm{K}$ & 14241 & 18641 & 28541 & 35841 & 24141 & \\
\hline $\mathrm{Mg}$ & 1747 & 1227 & 787 & 2337 & 2277 & \\
\hline $\mathrm{Na}$ & 15300 & 13700 & 22500 & 20300 & 23700 & \\
\hline $\mathrm{Ni}$ & 82 & 31 & 26 & -12 & 39 & \\
\hline$P$ & 4183 & 2713 & 4183 & 4213 & 5843 & \\
\hline$\overline{\mathrm{Pb}}$ & 168457 & 122557 & 145357 & 146657 & 158057 & \\
\hline Si & 267900 & 264800 & 87900 & 295600 & 204700 & \\
\hline $\mathrm{Ti}$ & 2287 & 1367 & 514 & 533 & 3217 & \\
\hline $\mathrm{Zn}$ & 136324 & 88024 & 111624 & 112624 & 123924 & \\
\hline $\mathrm{Sm}$ & 40 & 0 & 0 & 160 & 509 & \\
\hline & & & & & & \\
\hline Total me & 936105 & 730124 & 615081 & 835372 & 775126 & \\
\hline & & 11 & & & & - \\
\hline & & & & & & \\
\hline & & & & & & \\
\hline & & & & & & \\
\hline & & & & & & \\
\hline & & & & & & \\
\hline & & & & & & \\
\hline & & & & & & - \\
\hline & & & & & & \\
\hline & & & & & & \\
\hline & & & & & & \\
\hline
\end{tabular}




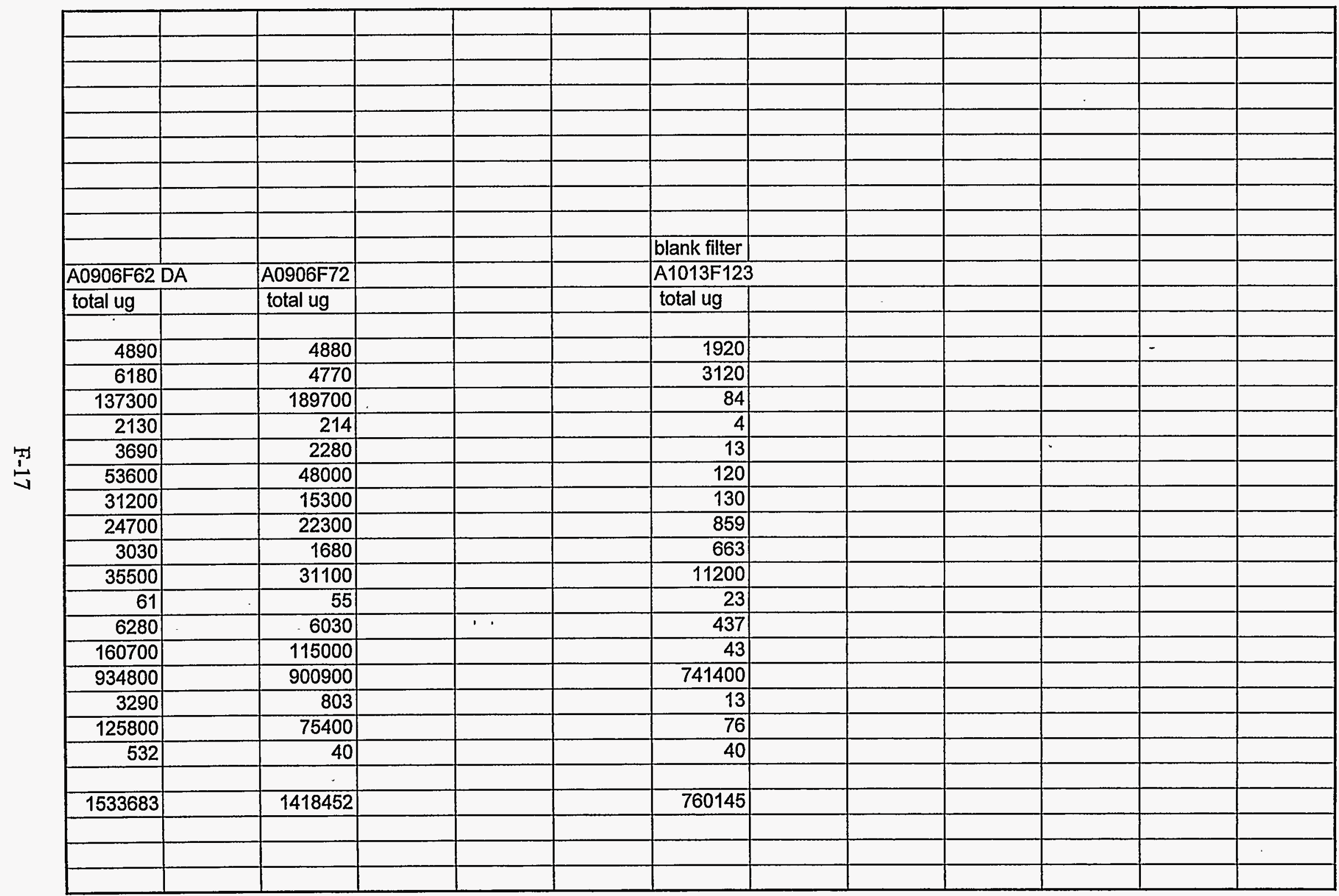




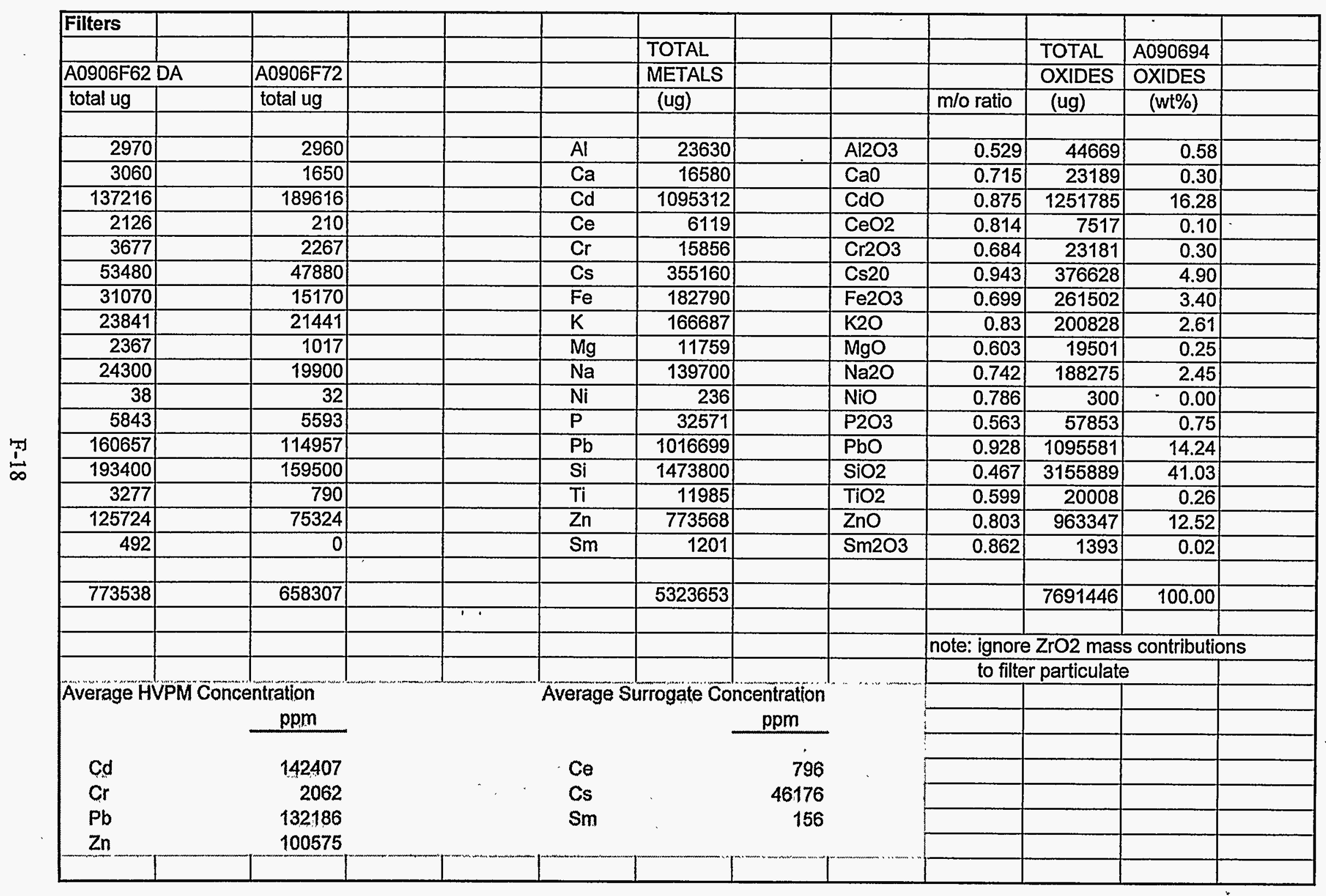




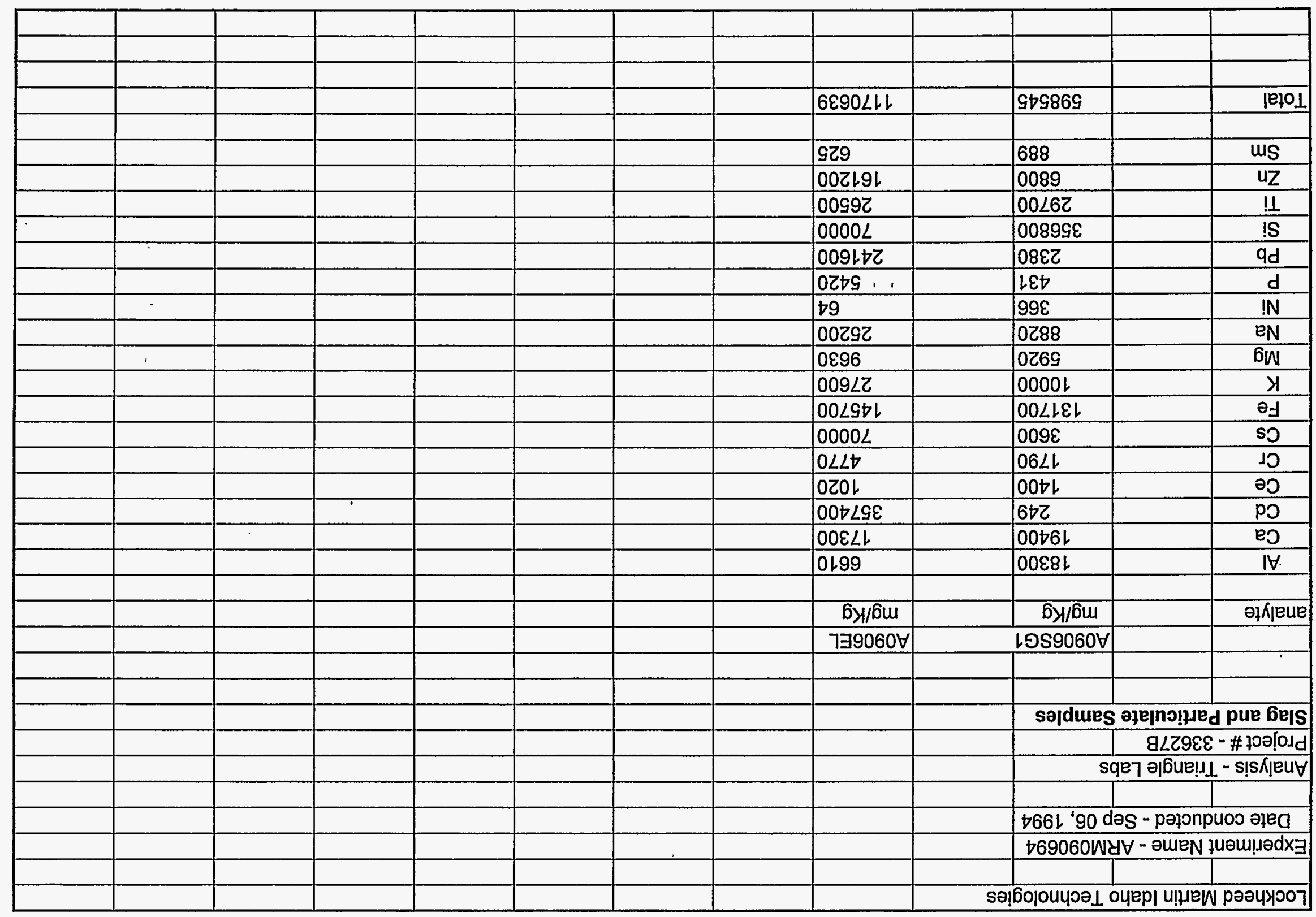




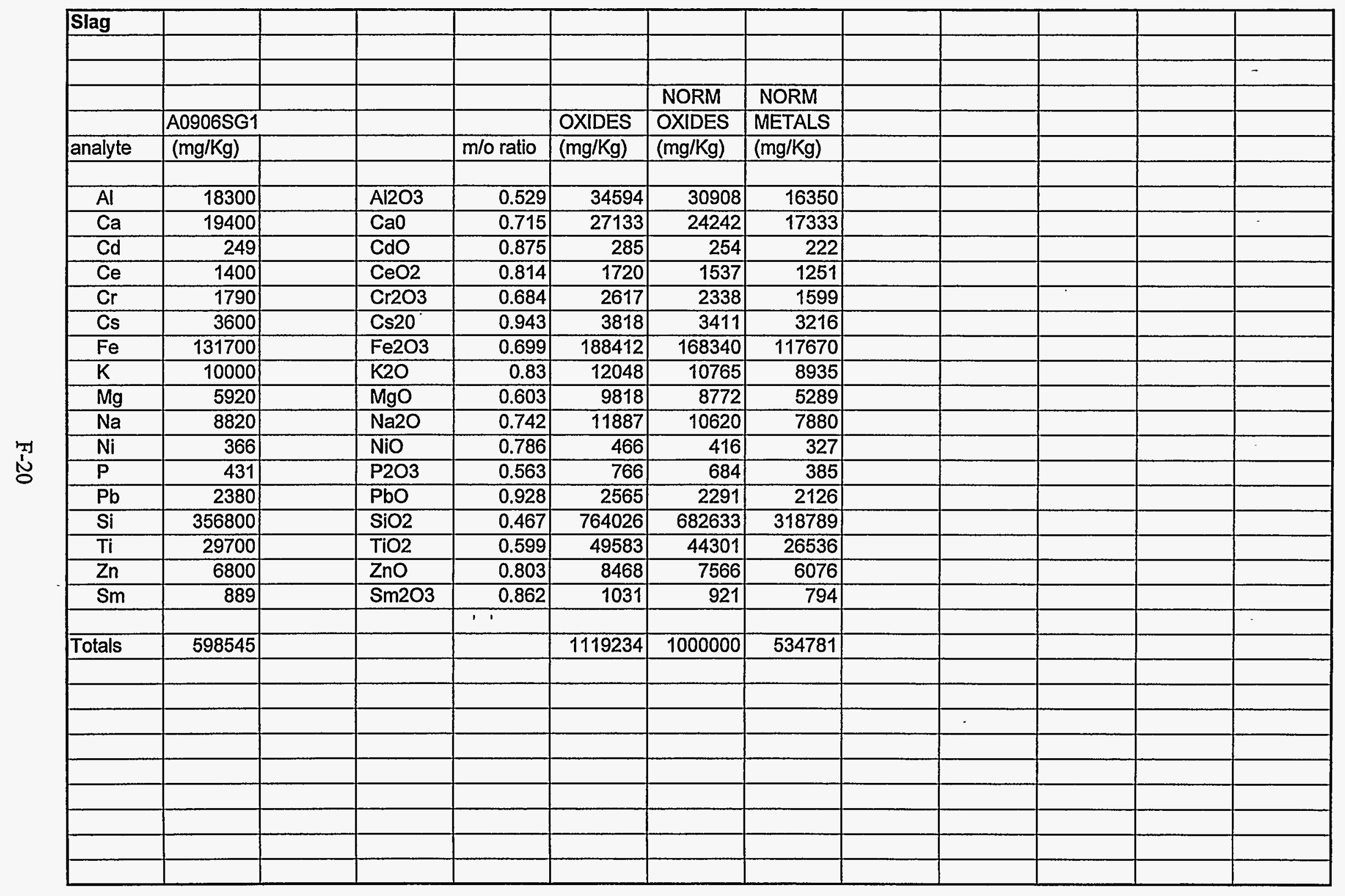




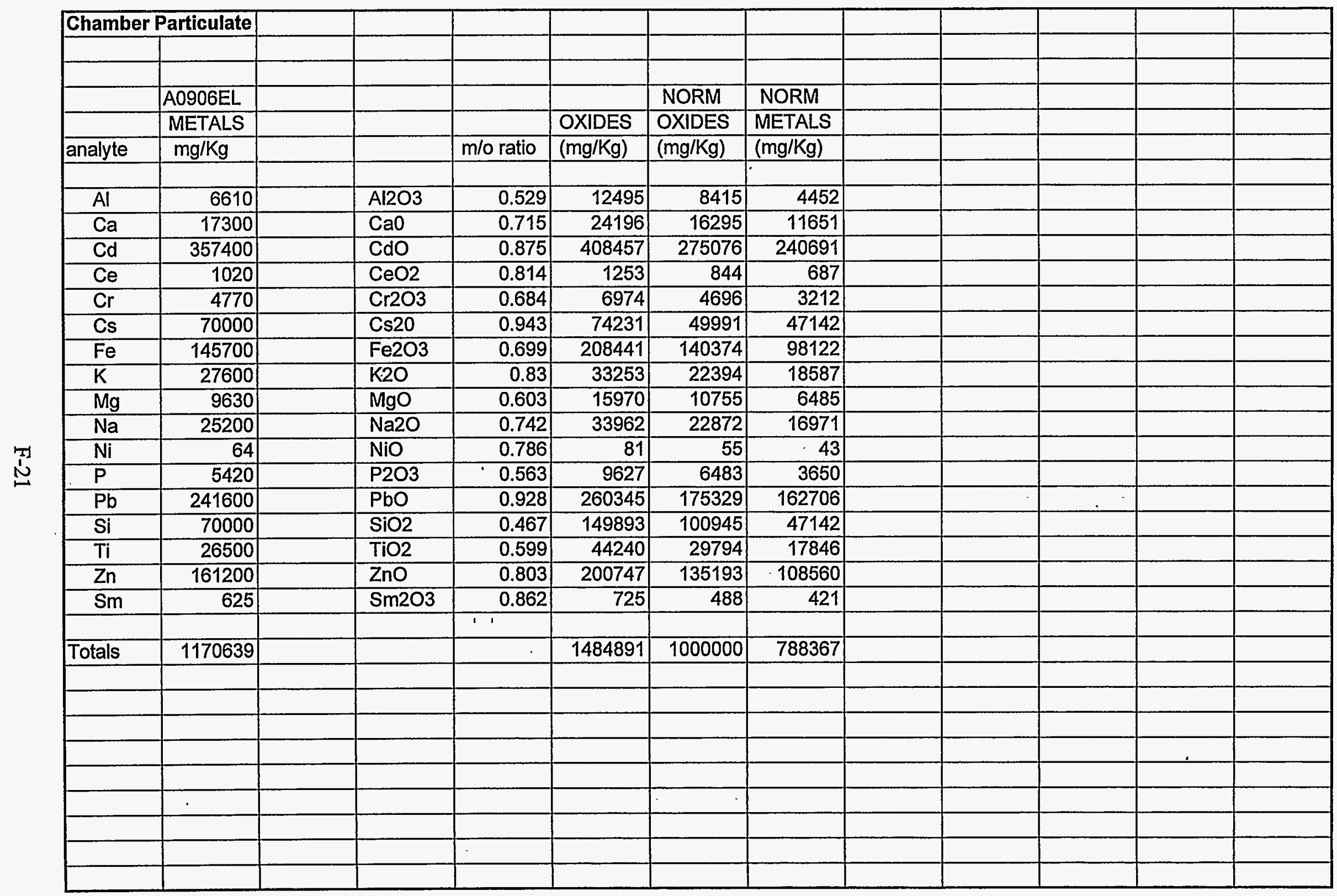




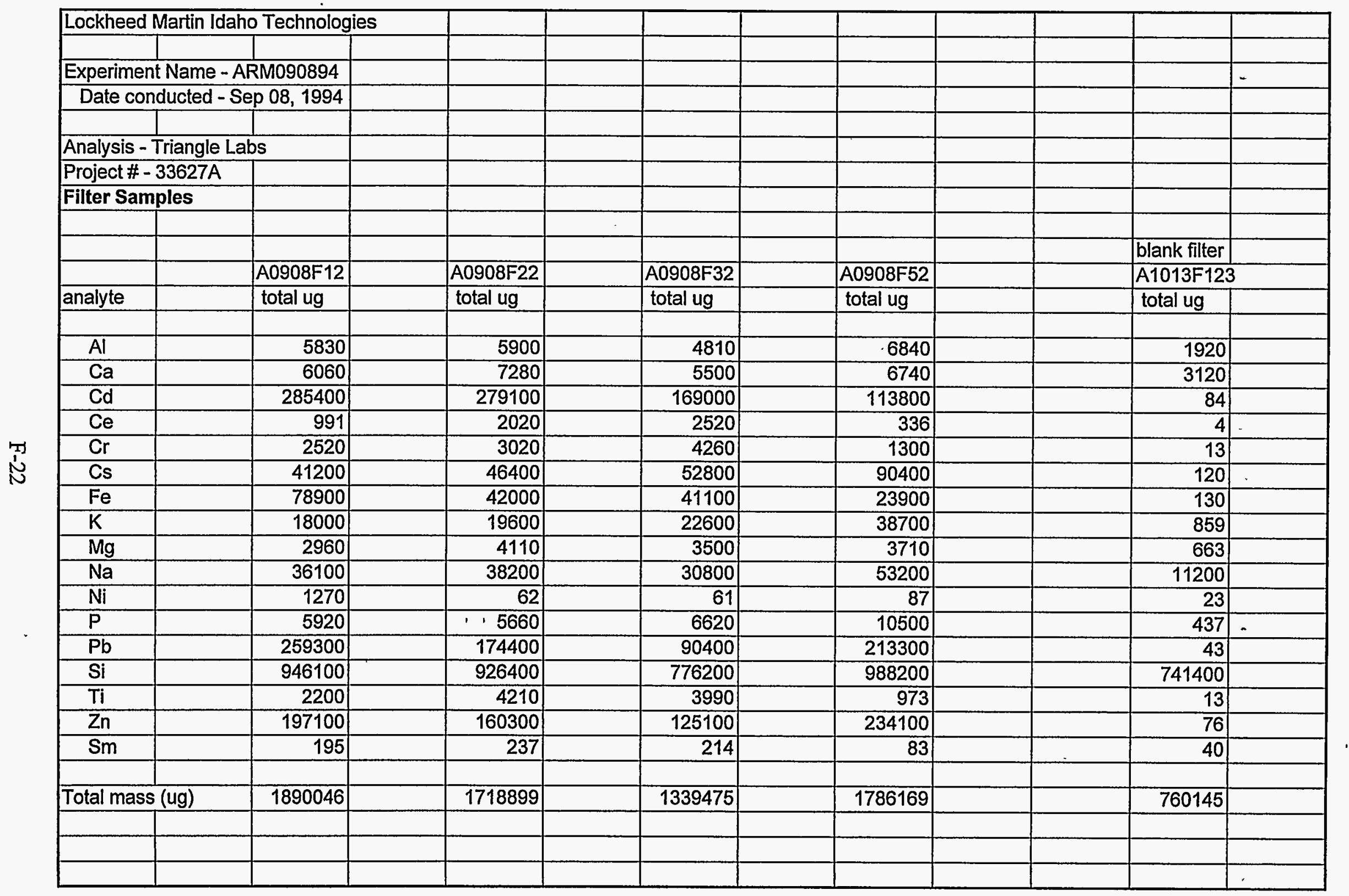




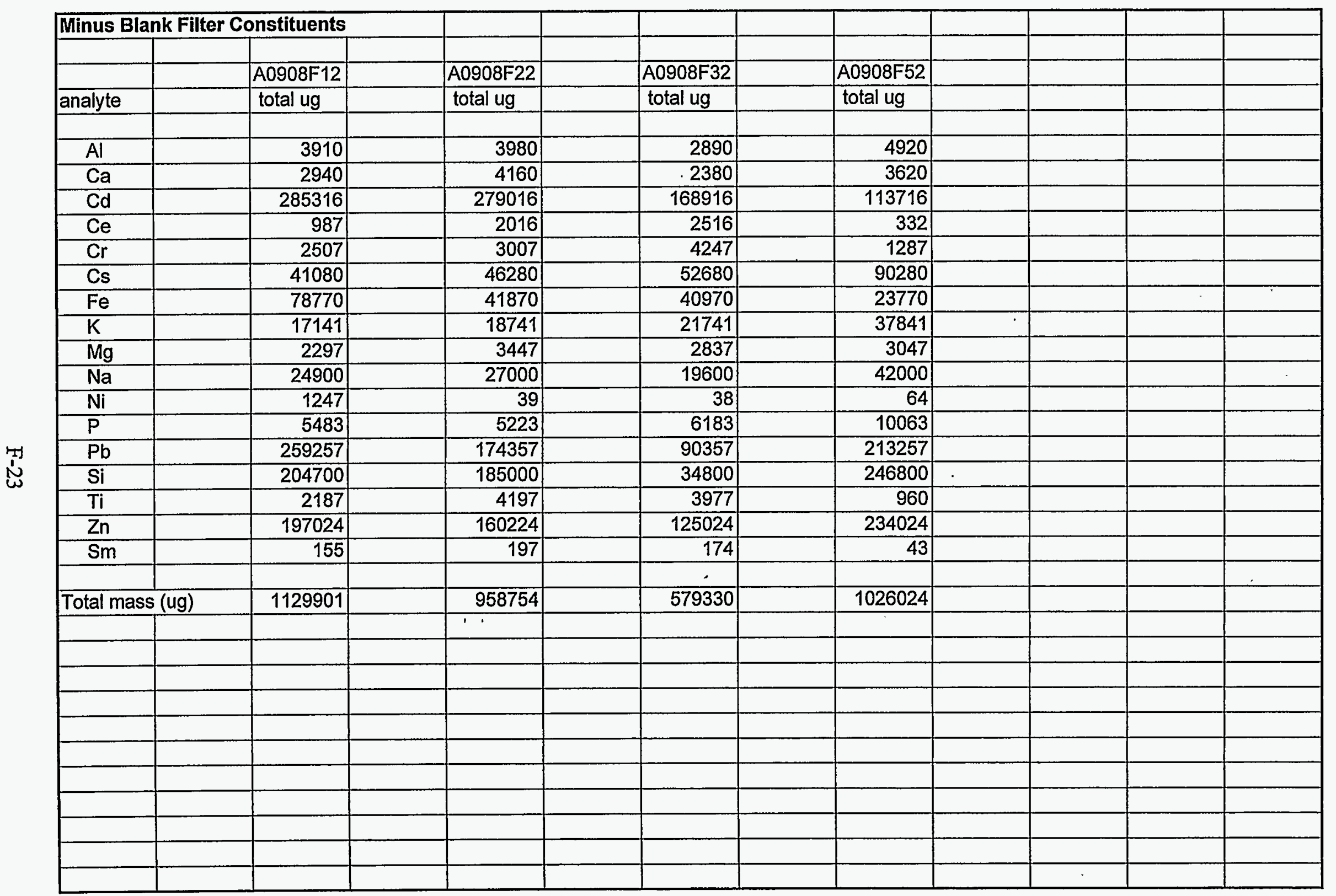




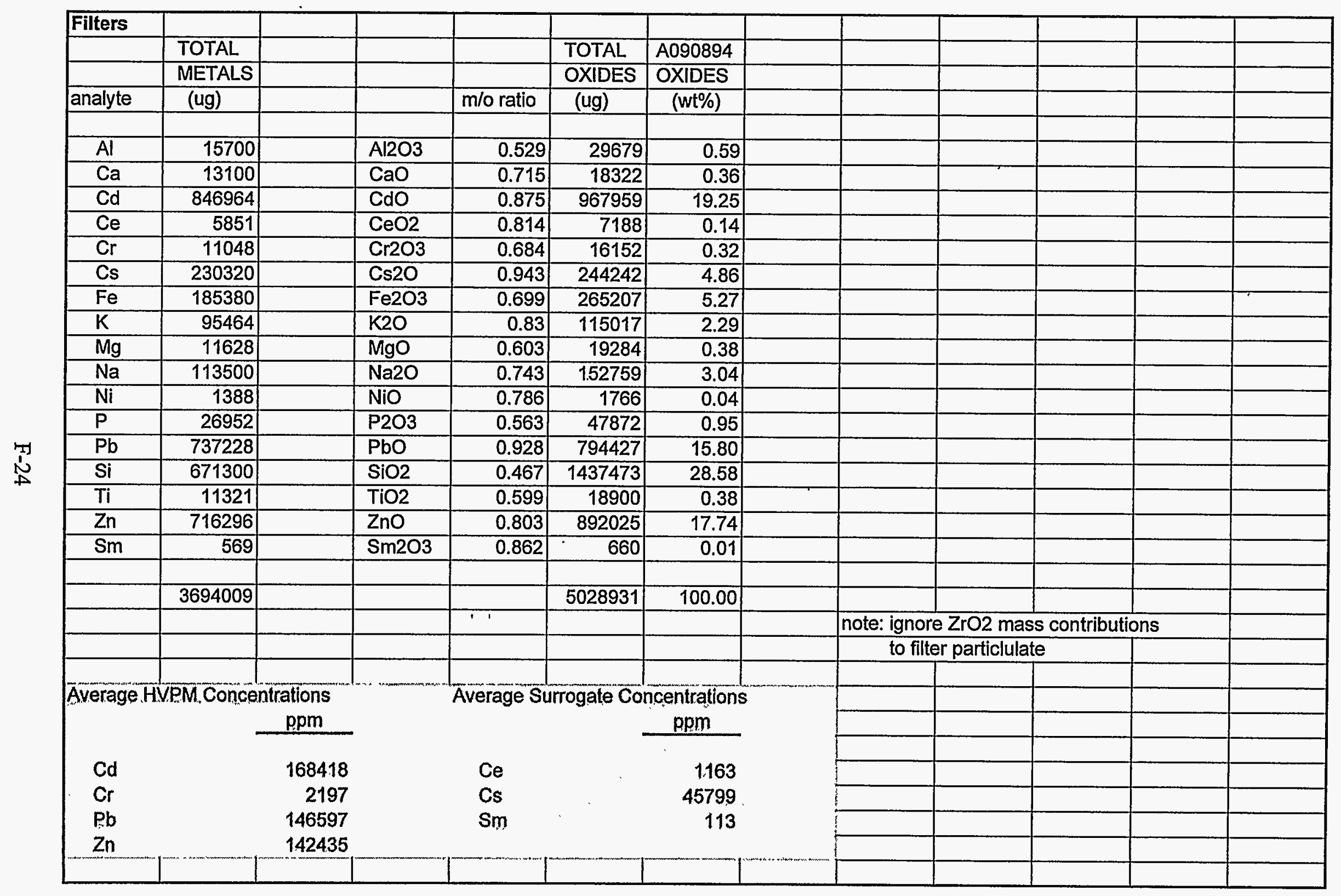




\begin{tabular}{|c|c|c|c|c|c|c|c|c|c|c|}
\hline \multicolumn{11}{|c|}{ Lockheed Martin Idaho Technologies } \\
\hline & & & & & & & & & & \\
\hline \multicolumn{11}{|c|}{ Experiment Name - ARM090894 } \\
\hline \multicolumn{11}{|c|}{ Date conducted - Sep 08, 1994} \\
\hline & & & & & & & & & & \\
\hline \multicolumn{11}{|c|}{ Analysis - Triangle Labs } \\
\hline \multicolumn{11}{|c|}{ Project \# - 33627B } \\
\hline \multicolumn{11}{|c|}{ Slag and Particulate Samples } \\
\hline & & & & & & & & & & \\
\hline & & & & & & & & & & \\
\hline & A0908SG1 & A0908SG1 & DA & A0908EL & & & & & & \\
\hline \multirow[t]{2}{*}{ analyte } & $\mathrm{mg} / \mathrm{Kg}$ & $\mathrm{mg} / \mathrm{Kg}$ & & $\mathrm{mg} / \mathrm{Kg}$ & & & & & & \\
\hline & & & & & & & & & & \\
\hline $\mathrm{Al}$ & 20900 & 20800 & & 8080 & & & & & & \\
\hline $\mathrm{Ca}$ & 22700 & 22600 & & 21500 & & & & & & \\
\hline $\mathrm{Cd}$ & 96 & 90 & & 397300 & & & & & & \\
\hline $\mathrm{Ce}$ & 1760 & 1760 & & 2110 & & & & & & \\
\hline $\mathrm{Cr}$ & 1950 & 1950 & & 4690 & & & & & & \\
\hline Cs & 4370 & 4370 & & 59400 & & & & & & \\
\hline $\mathrm{Fe}$ & 122300 & 121700 & & 168500 & & & & & & \\
\hline $\mathrm{K}$ & 11000 & 11100 & & 24100 & & & & & & \\
\hline $\mathrm{Mg}$ & 5980 & 5960 & & 10900 & & & & & & \\
\hline $\mathrm{Na}$ & 8760 & 8690 & & 27300 & & & & & & \\
\hline $\mathrm{Ni}$ & 23 & 23 & & 119 & & & & & & \\
\hline $\bar{P}$ & 508 & 1.528 & & 6020 & & & & & & \\
\hline $\mathrm{Pb}$ & 2060 & 2040 & & 240100 & & & & & & \\
\hline $\mathrm{Si}$ & 238800 & 241200 & & 81900 & & & & & & \\
\hline $\mathrm{Ti}$ & 32800 & 32600 & & 35400 & & & & & & \\
\hline $\mathrm{Zn}$ & 1870 & 1850 & & 16900 & & & & & & \\
\hline $\mathrm{Sm}$ & 899 & 1040 & & 1120 & & & & & & \\
\hline & & & & & & & & & & \\
\hline Total & 476776 & 478301 & & 1105439 & & & & & & \\
\hline & & & & & & & & & & \\
\hline & & & & & & & & & & \\
\hline & & & & & & & & & & \\
\hline
\end{tabular}




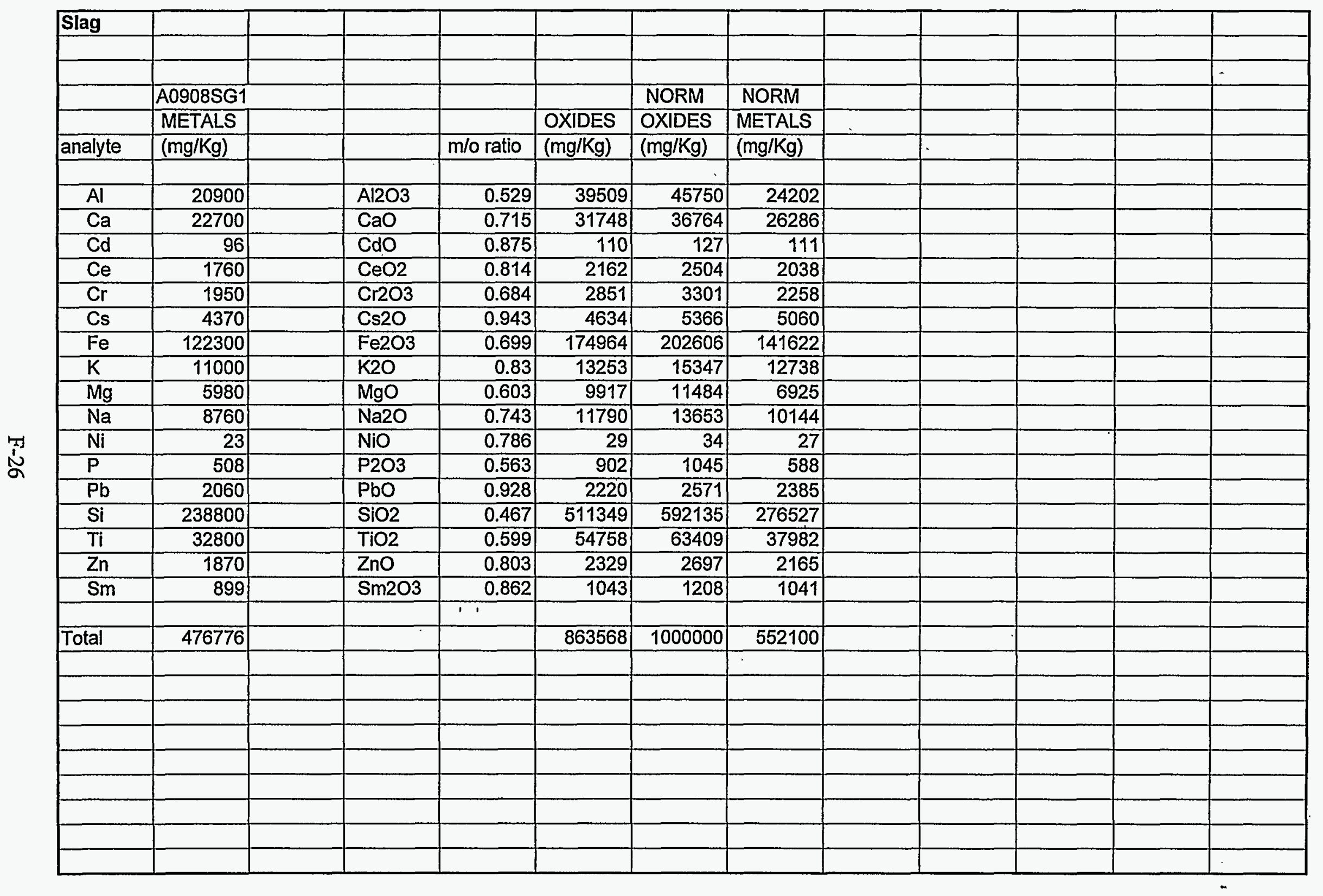




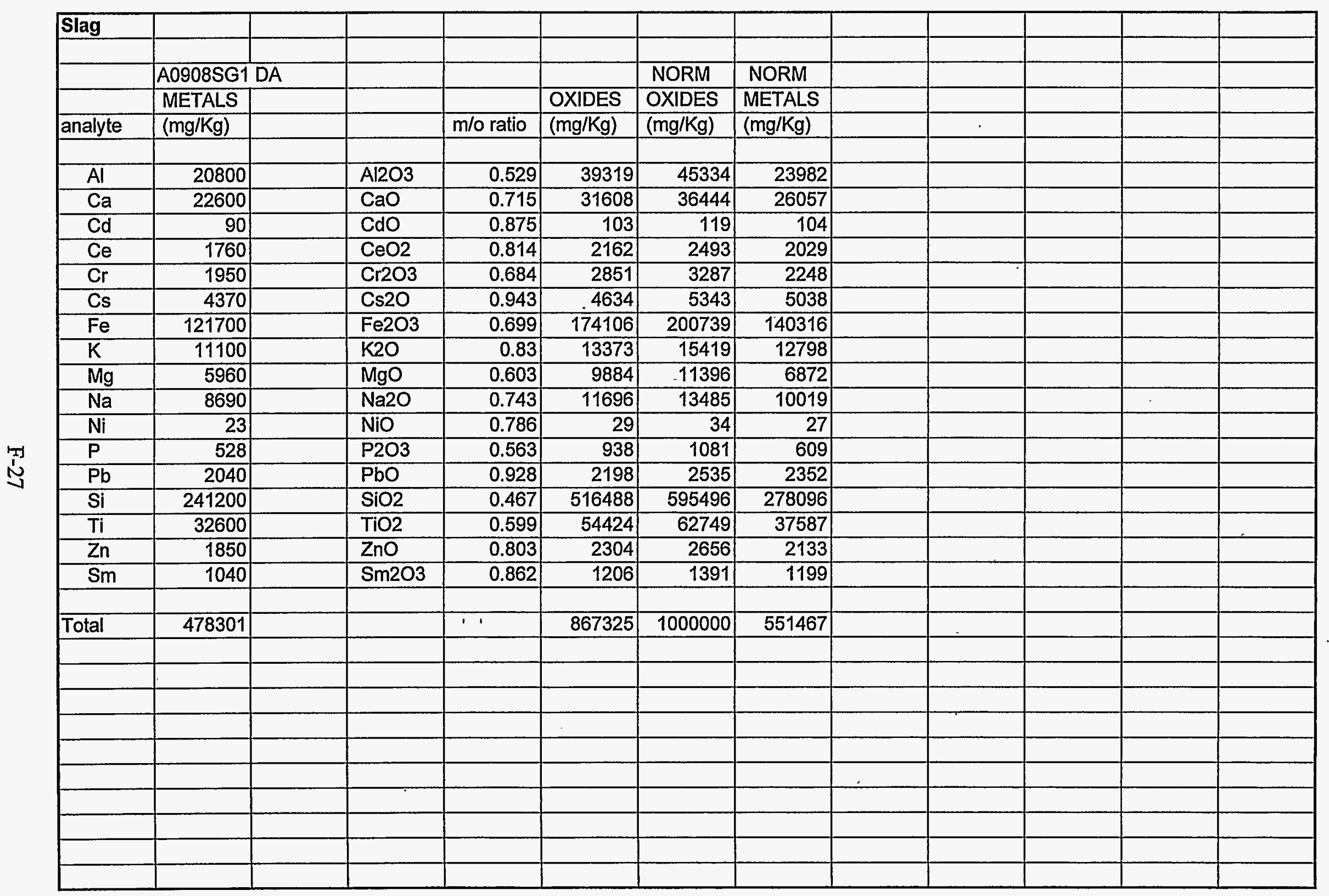




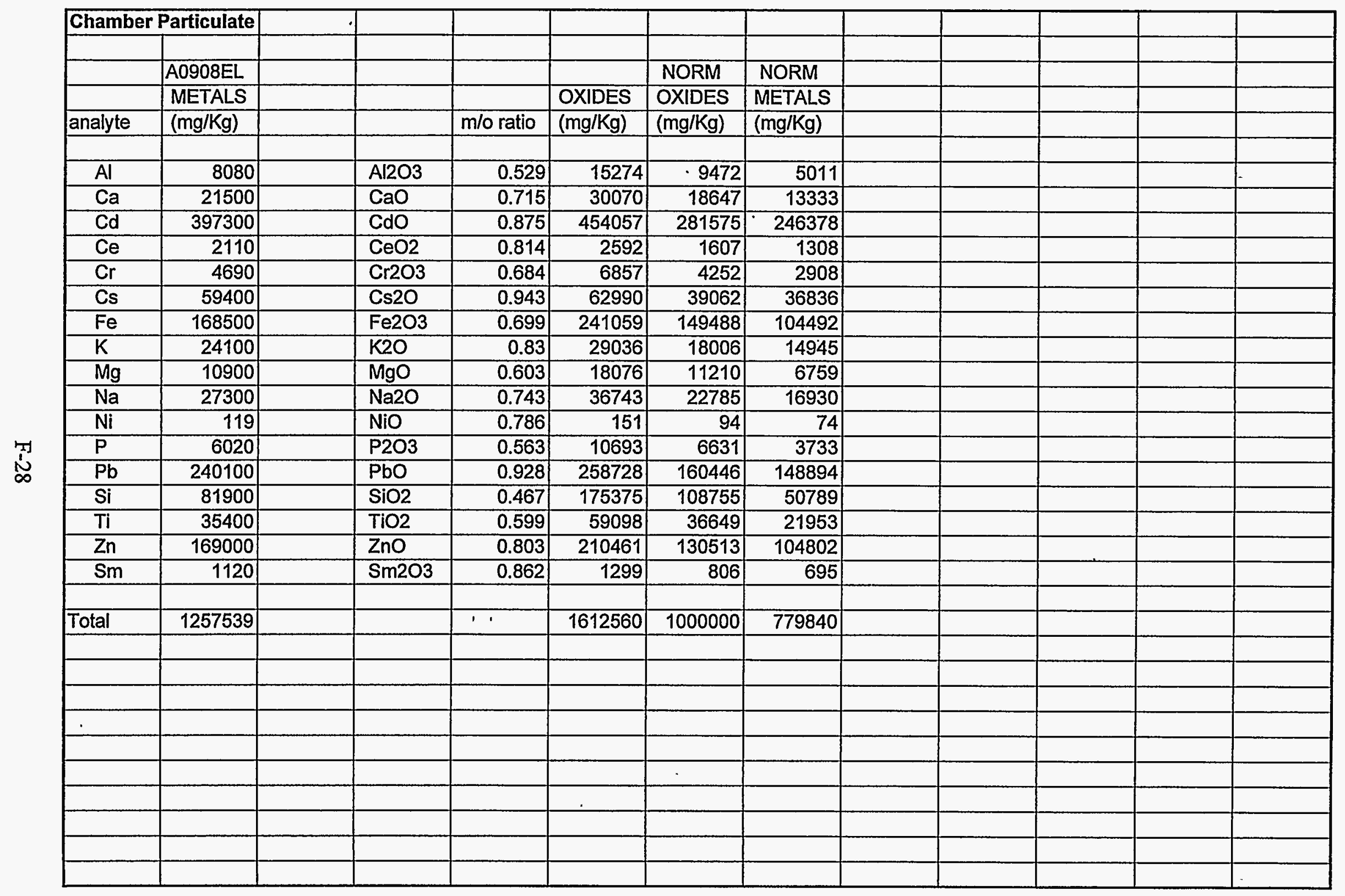




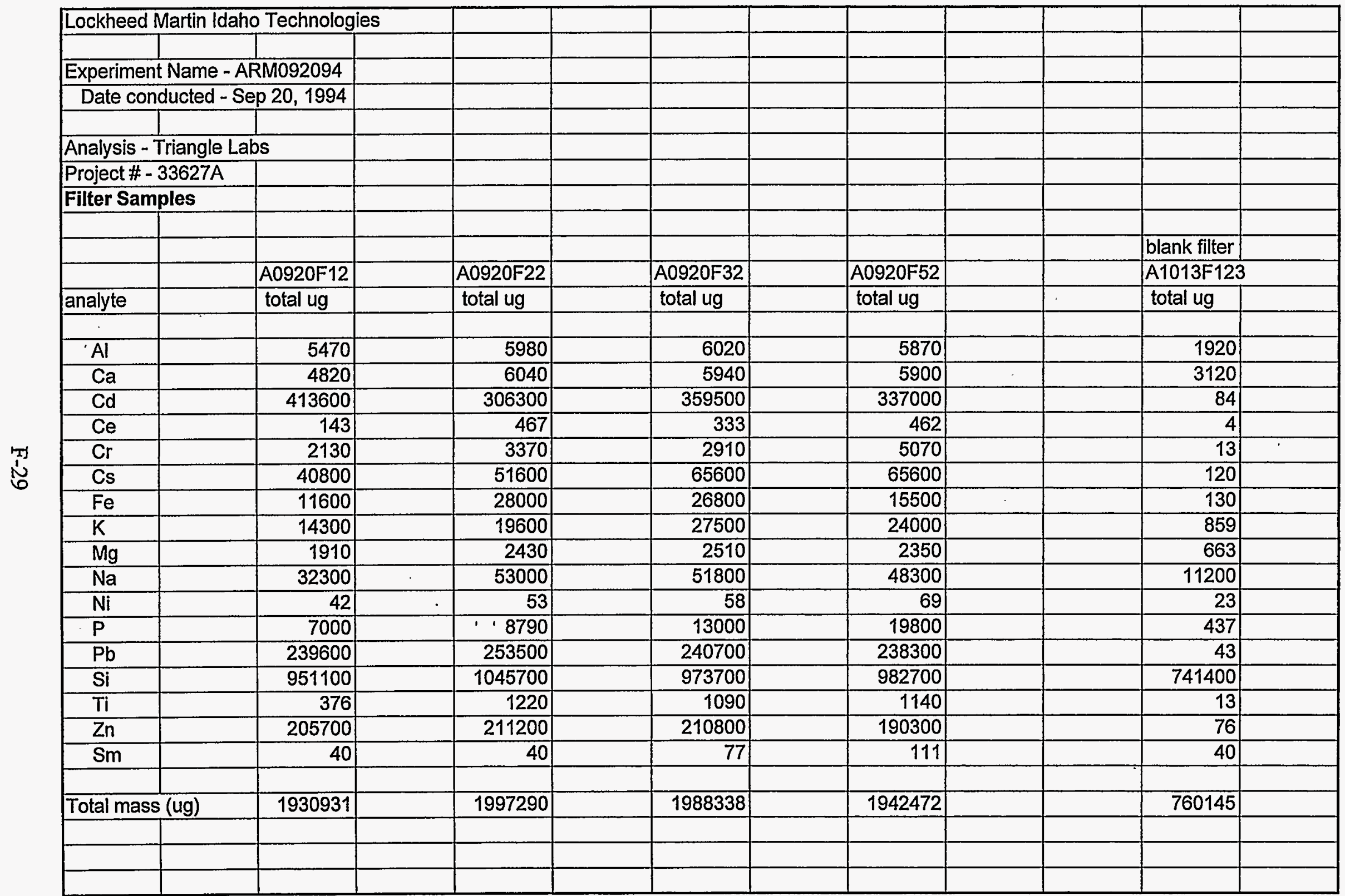




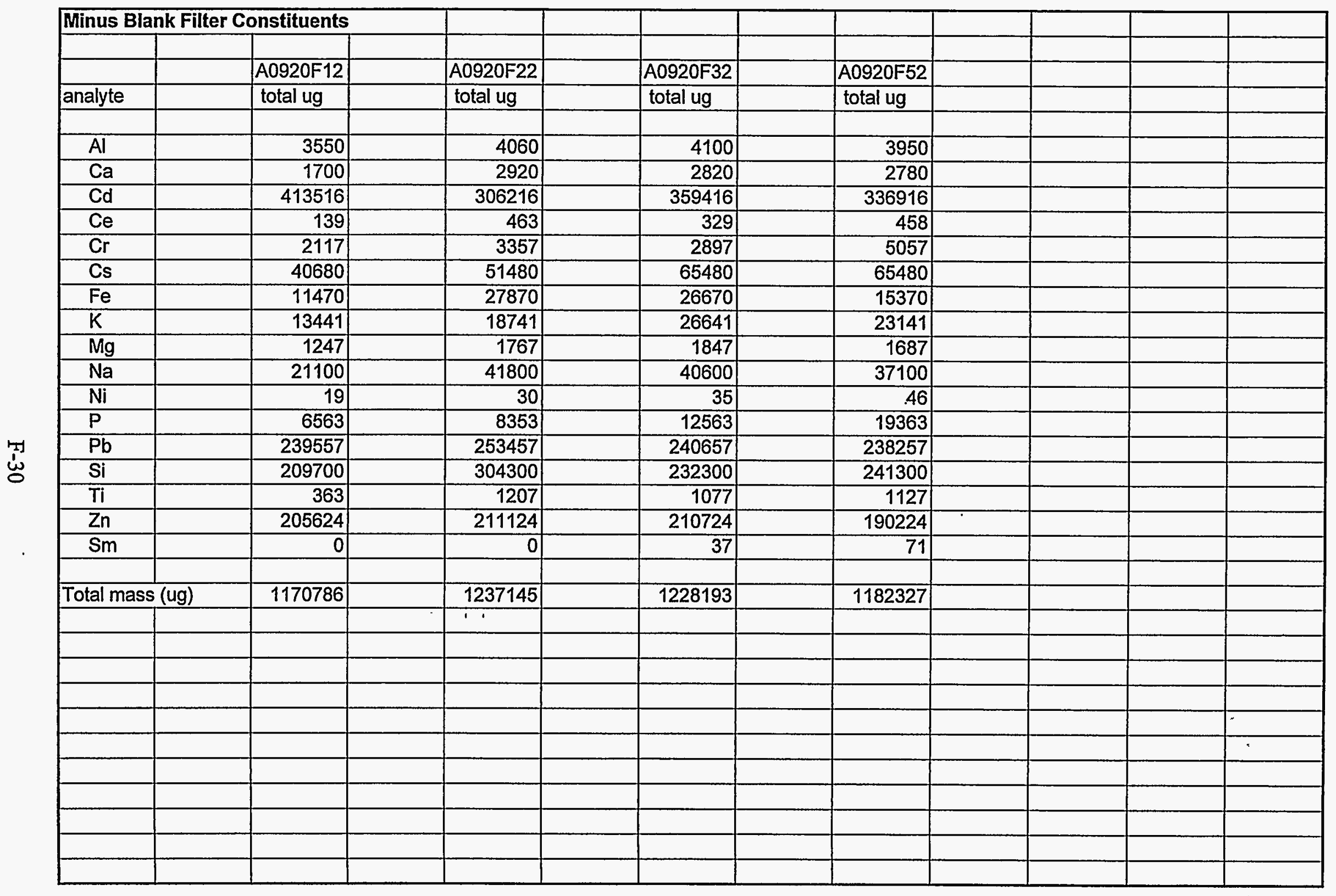




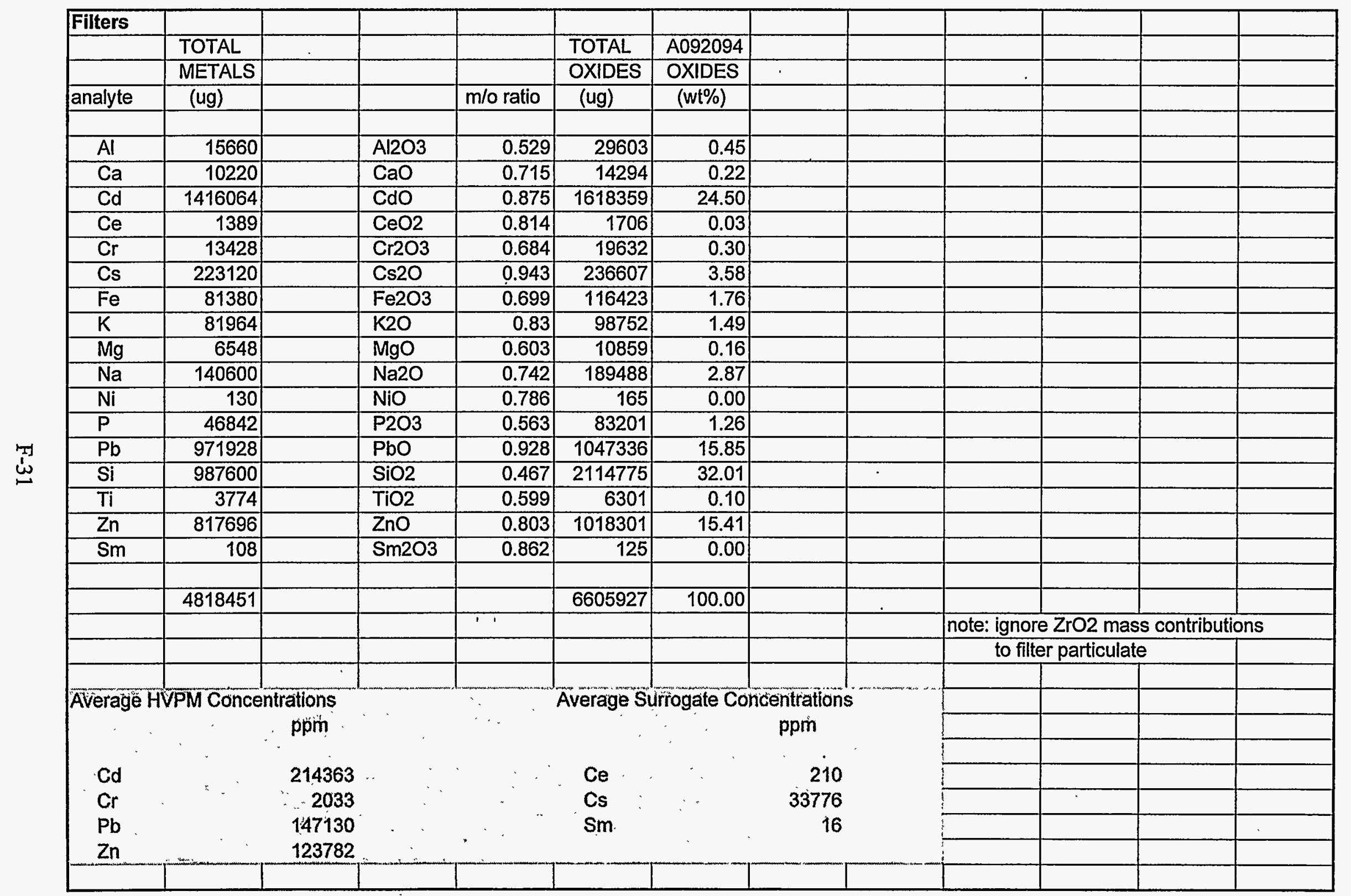




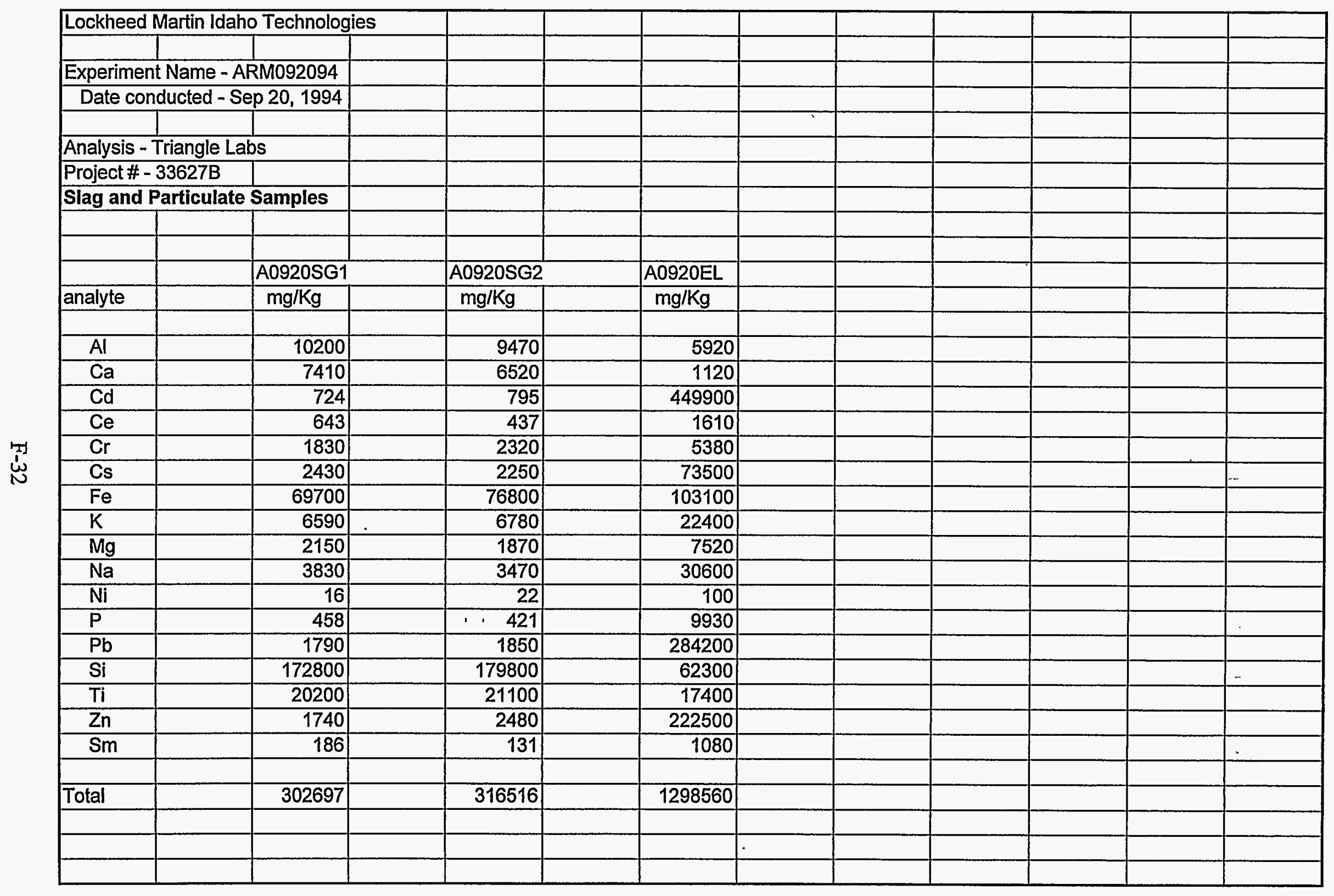




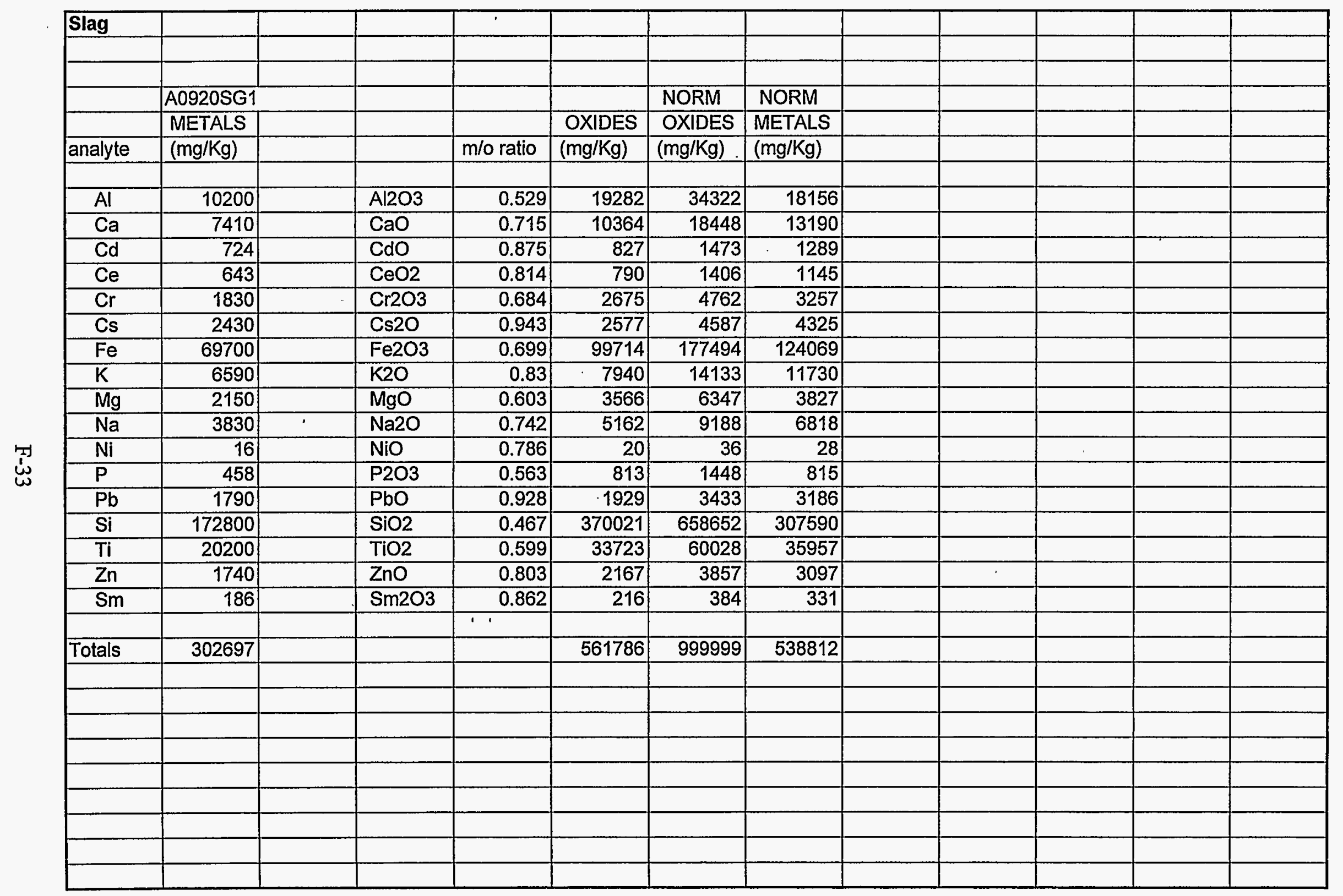




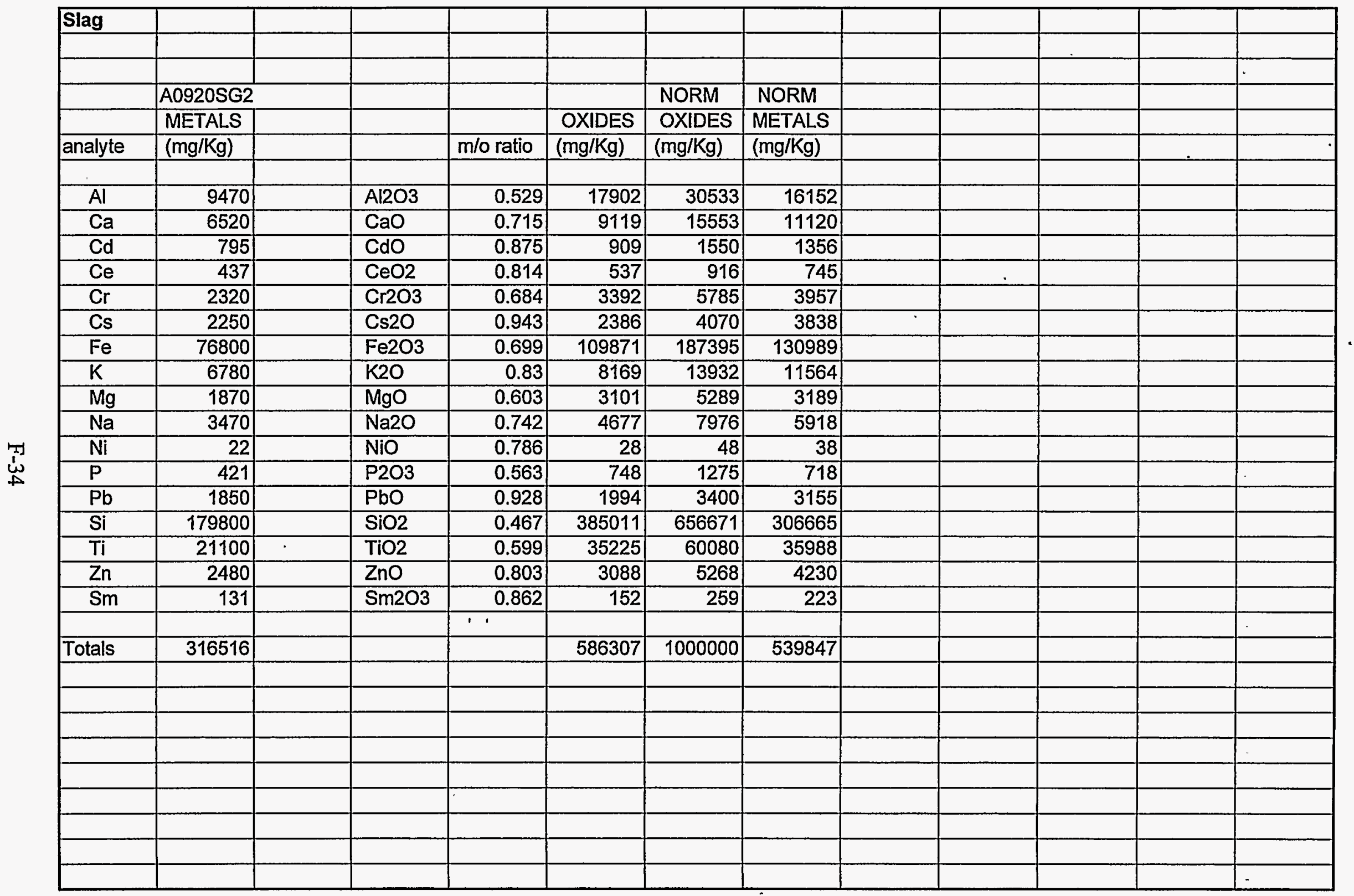




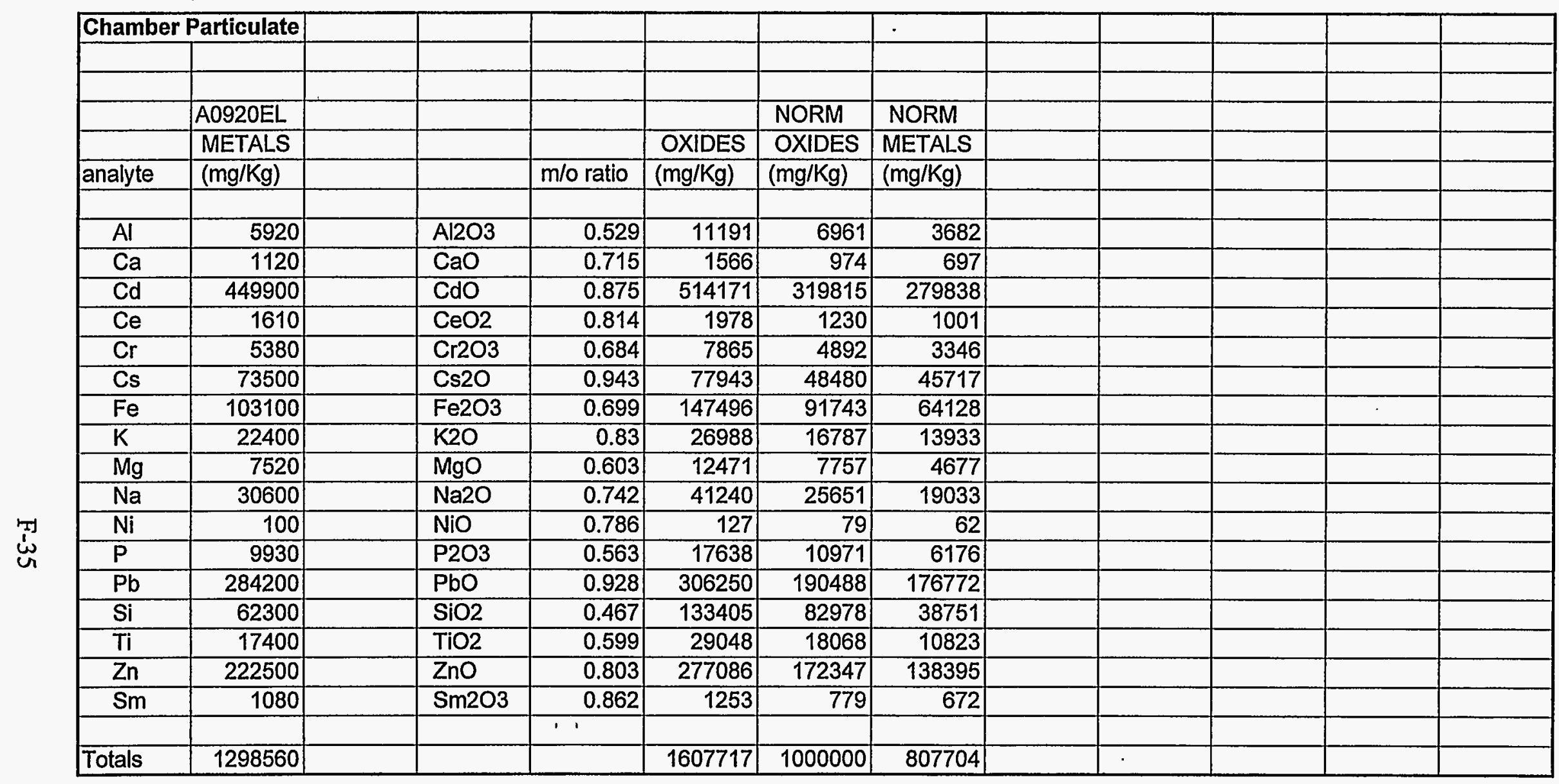




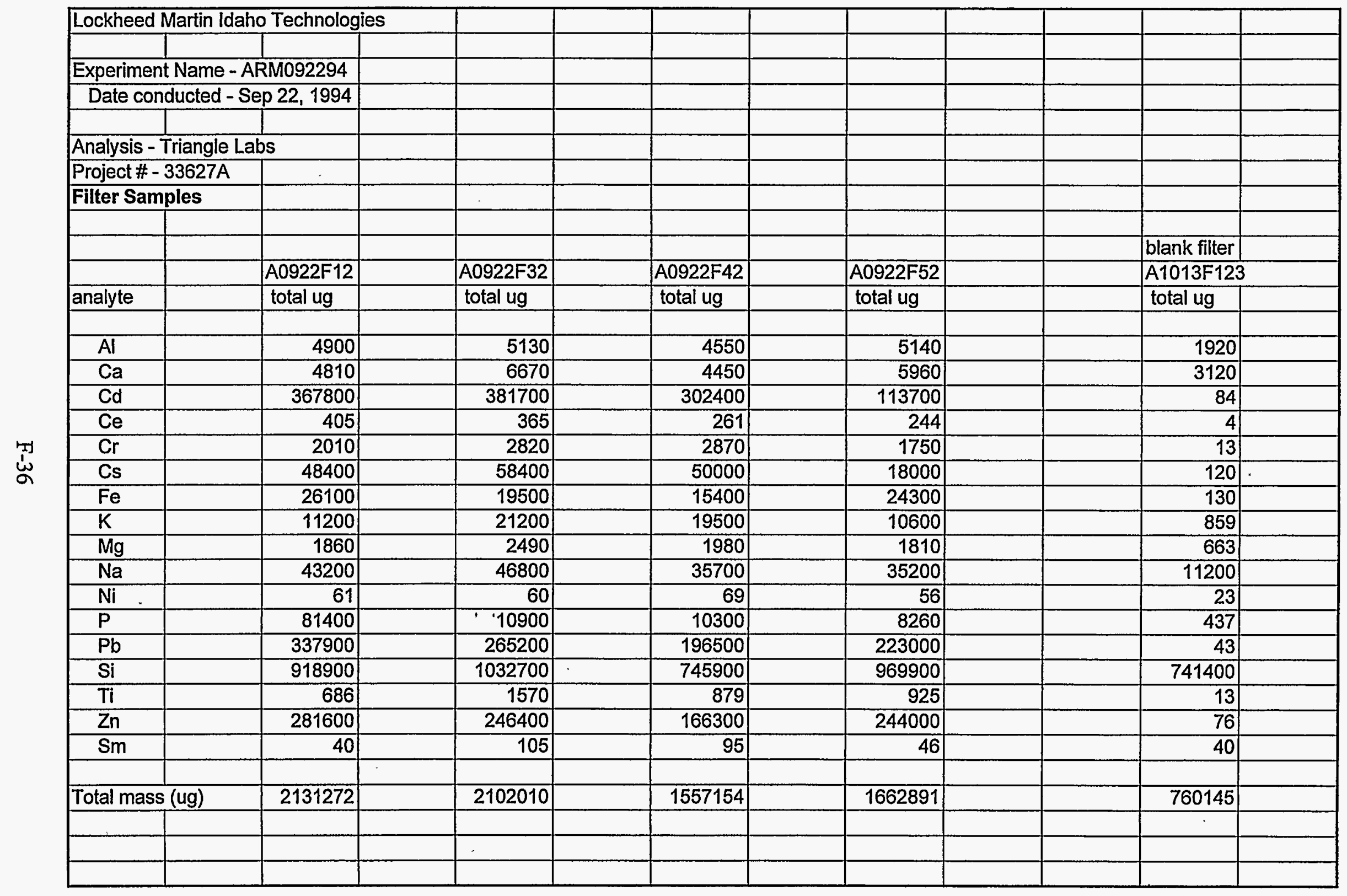




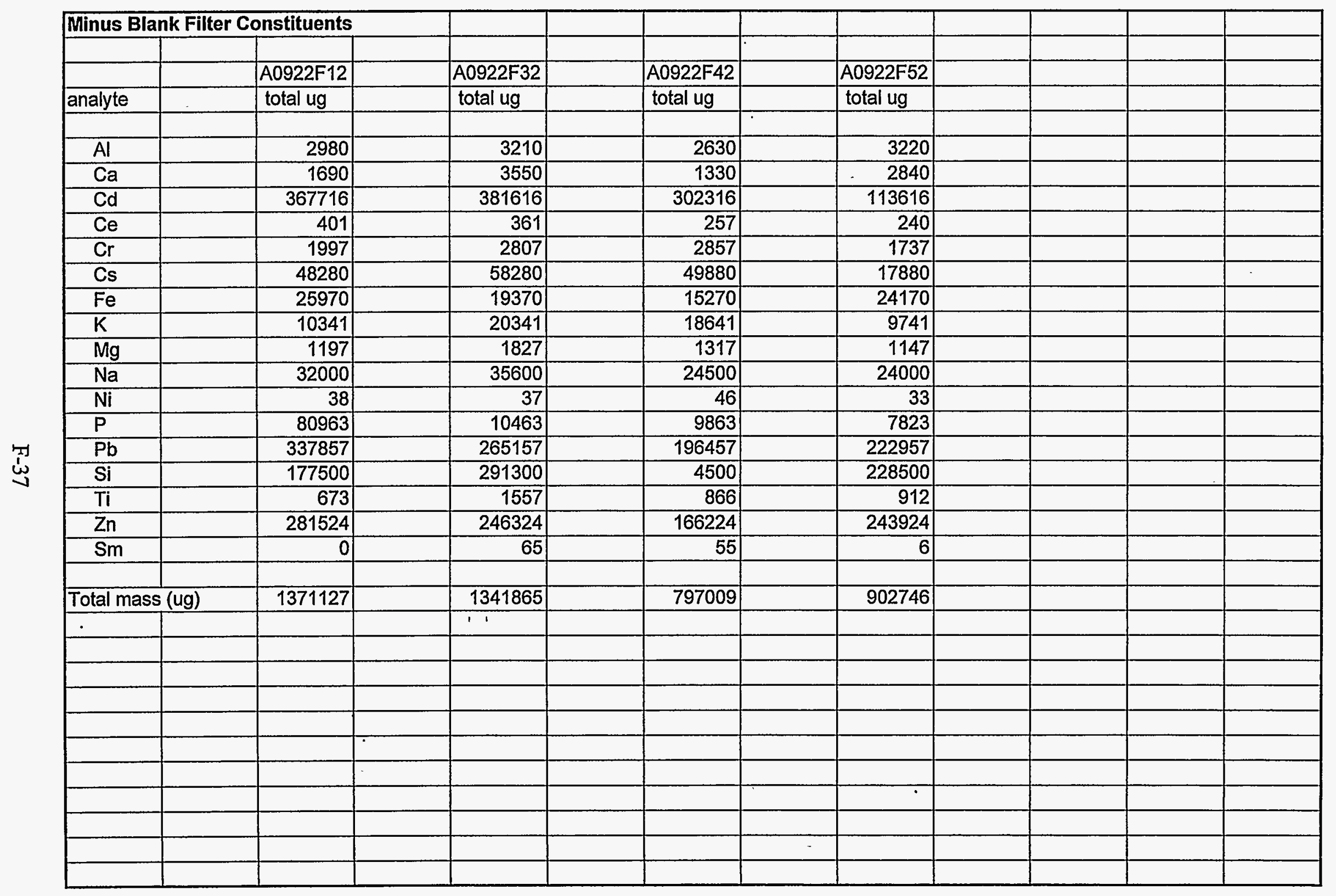




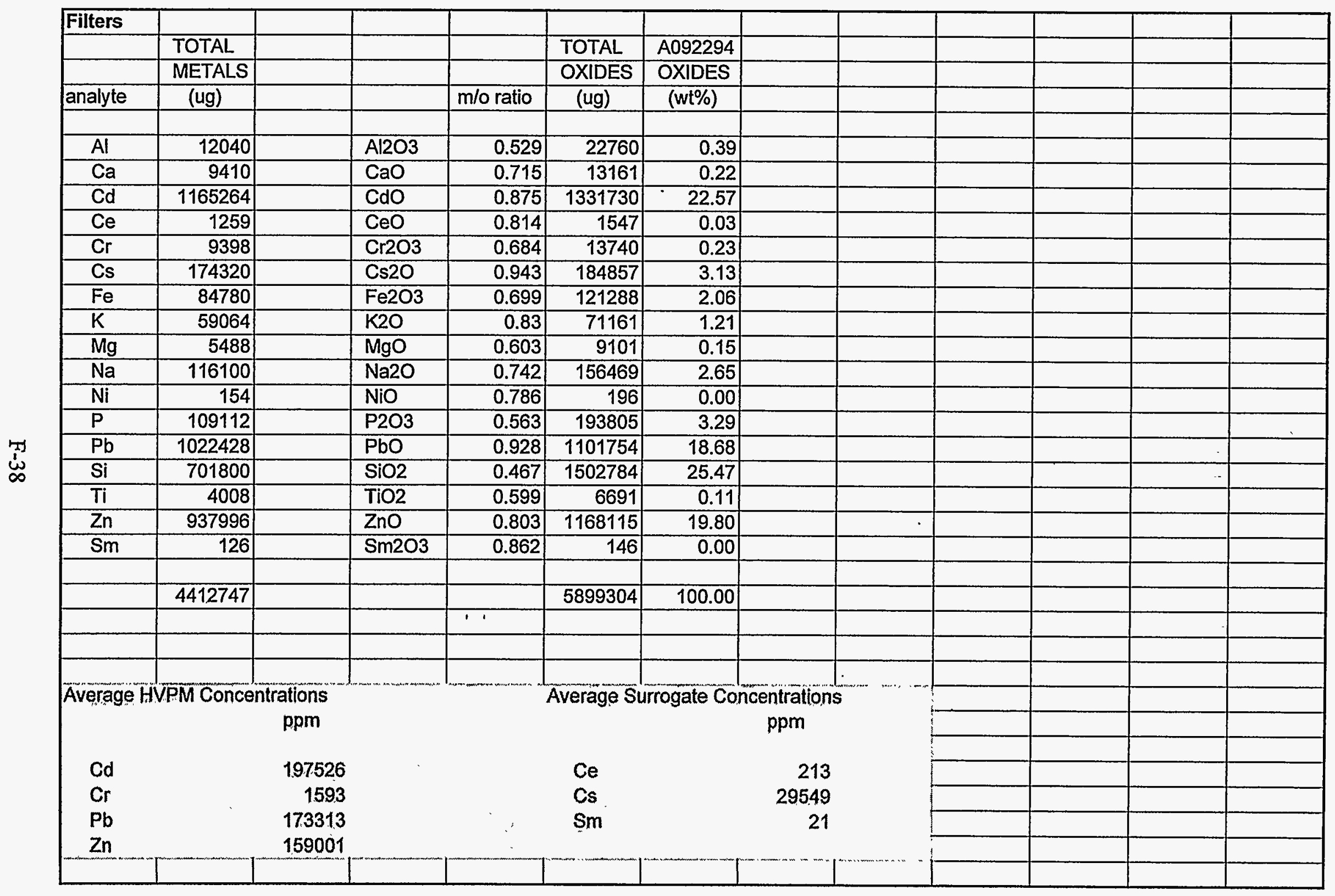




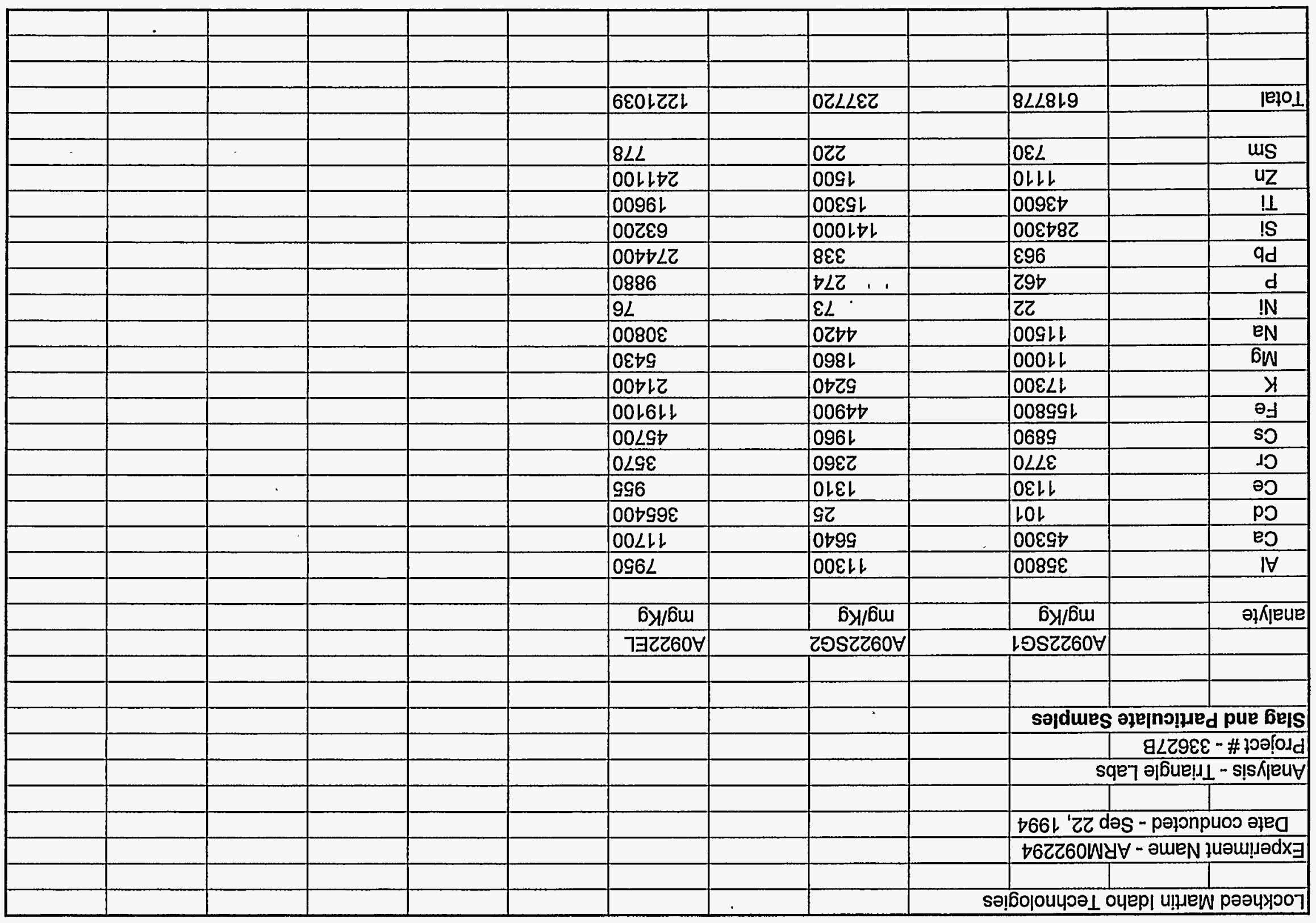




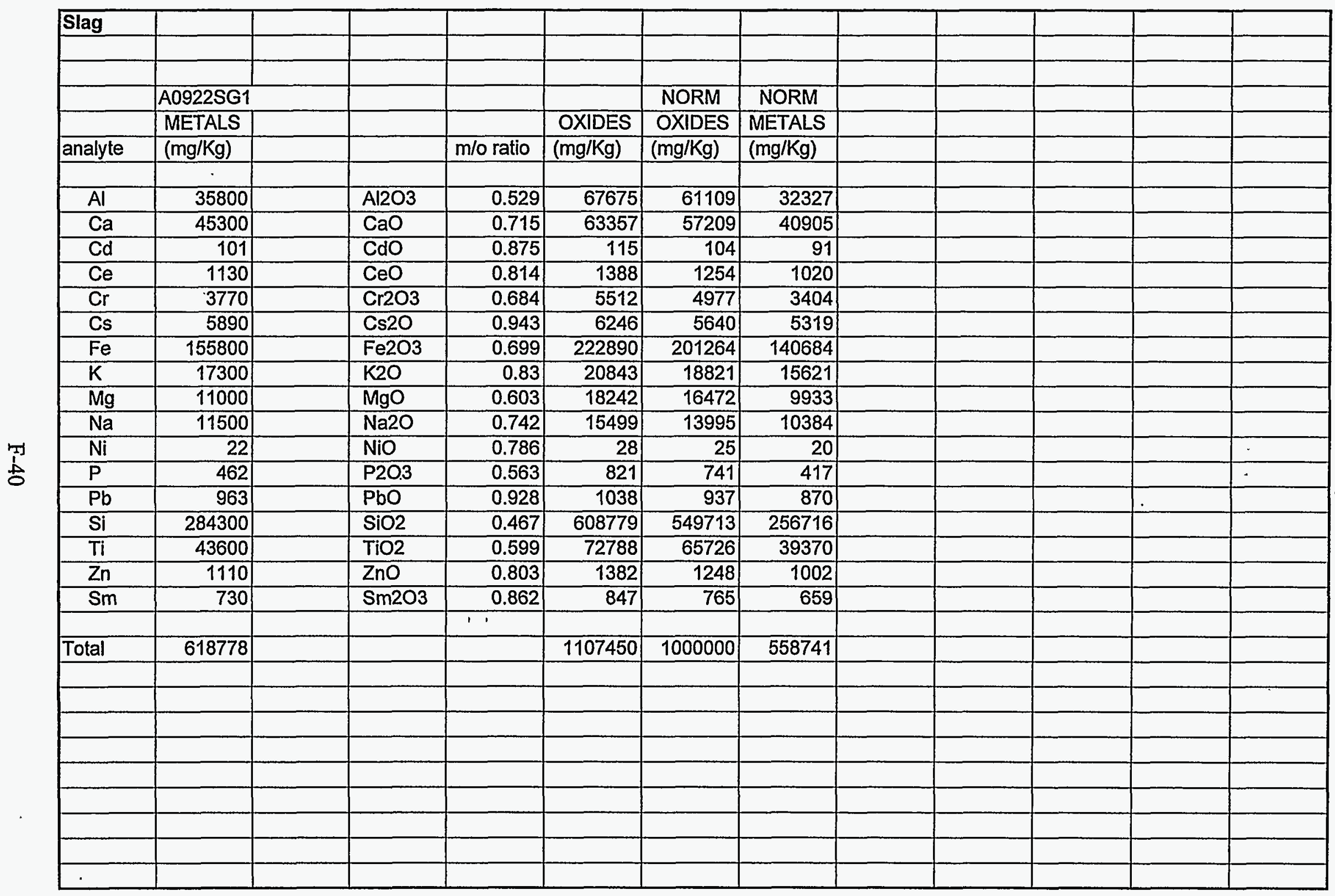




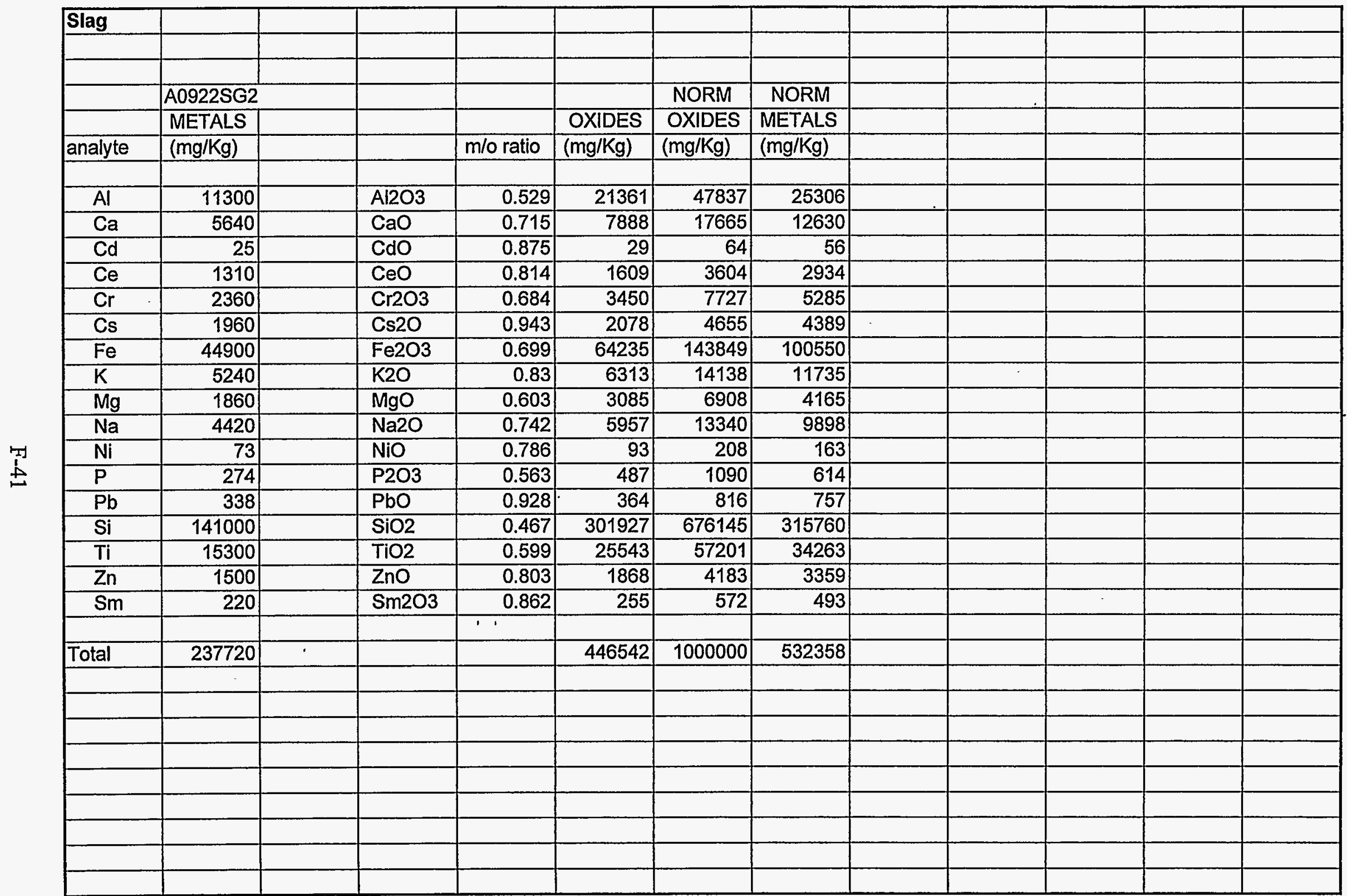




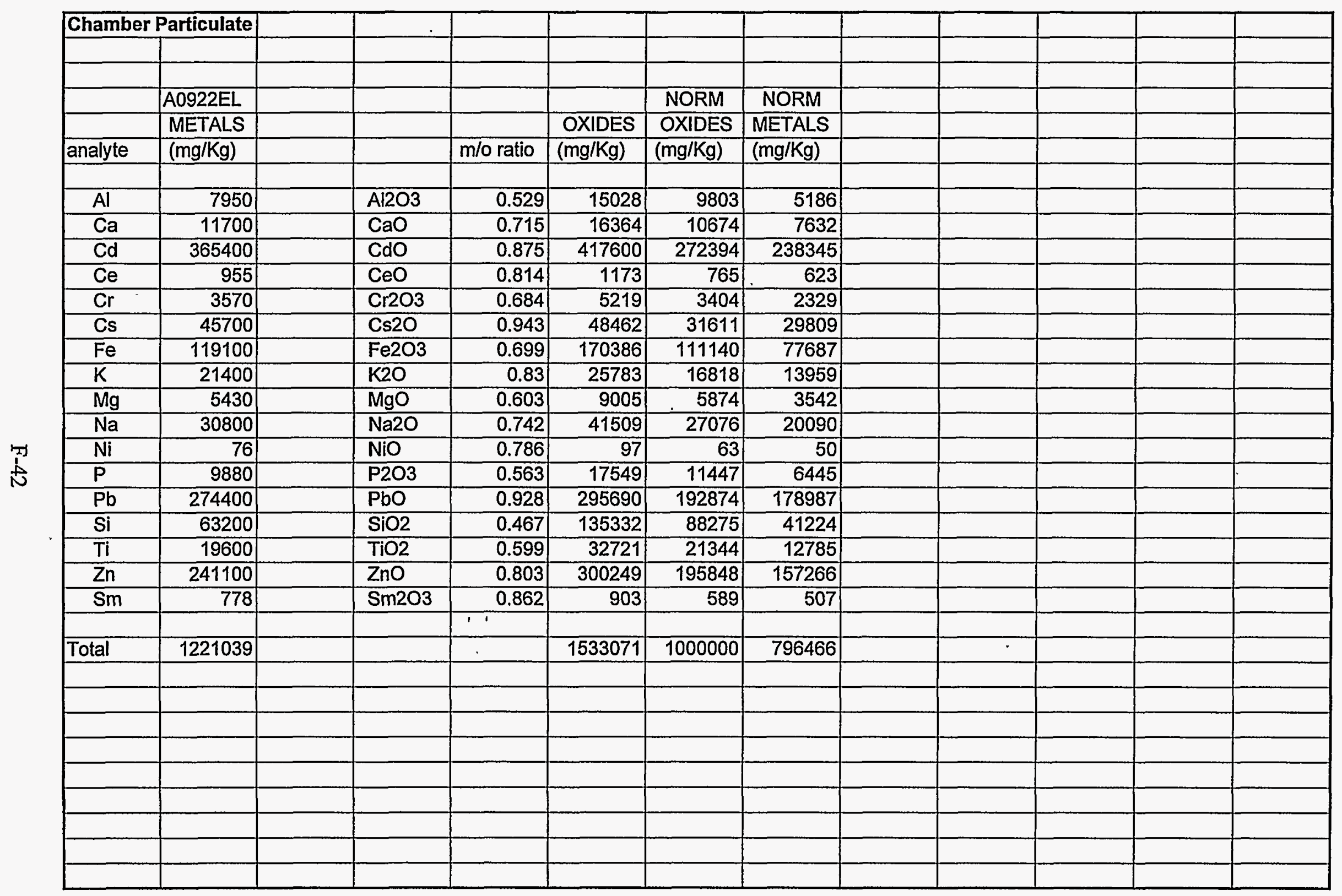

